Soil $\mathbf{N}$ mineralization dynamics as affected by pure and mixed application of leafy material from leguminous trees used in planted fallow in Brazil

\title{
Doctoral Dissertation
}

submitted for degree of Doctor of Agricultural Sciences of the Faculty of Agricultural Sciences

George-August-University Göttingen (Germany)

by

José Henrique Cattanio

Born in Andradina-São Paulo-Brazil

Göttingen, 14 November 2002 
$1^{\text {st }}$ examiner: Prof. Dr. P. Vlek

$2^{\text {nd }}$ examiner: Prof. Dr. N. Claassen

Date of oral examination: 14 November 2002 


\section{Acknowledgements}

I would like to express my sincere thanks to Prof. Dr. P. L. G. Vlek for accepting the theme of my research as well as for his support, assistance, and valuable advice during this study. I also thank Prof. Dr. N. Claassen for his interest and being co-referee as well as for his comments and advice. Thanks also go to Prof. Dr. E. Veldkamp for his kindness of being a member of the examination committee.

I would like to express my sincere thanks to Dr. R. Kühne for his support, assistance, and valuable advice during my studies. My thanks are also extended to the staff of the Institute of Agronomy in the Tropics, especially to Dr. A. Moawad, Dr. H. Koch, Dr. B. Mass, Ms. C. Conradt and Ms. U. Ronsöhr (for technical assistance), and for Ms. M. Friedrich, Mr. T. Österreich, Mr. W. Kiedos and Mr. W. Eisenberg for their support. Tanks also go to Mr. Langel for his support in analyzing the labeled material, Dr. M. Corre for help in the ${ }^{15} \mathrm{~N}$ methodology and Ms. M. Jend for her grammatical suggestions and corrections.

The generous financial support provided by the Brazil Council for Scientific and Technological Development (CNPq), for fellowship, Germany Academic Exchange Service (DAAD) for German language course, and German Federal Ministry of Education, Science, Research and Technology $(\mathrm{BMB}+\mathrm{F})$ for research support, are highly recognized and acknowledged.

I would like to express my gratitude to all my colleagues at the Institute of Agronomy in the Tropics (University of Göttingen) and at Center for Development Research (ZEF-University of Boon). Specials thanks go to Dr. K. Vielhauer, Dr. M. Denich, Dr. U. Diekmann, Dr. M. Fosu, Dr. S. Brienza, Dr. S. Kato, Dr. O. Kato, Dr. M. Cisse, and Dr. A. Luki.

I thank all my colleagues and the staff of the "Empresa Brasileira de Pesquisa Agro-florestal (EMBRAPA-Amazonia Oriental)" and "SHIFT-Capoeira project", especially for Dr. T. Sá and Dr. M. Kanashiro, for their support during the field phase of the work.

My wish to thank Germano and Stephanie, Martin and Eliana, Martin and Karla, and Rubens and Julia for the moral support and for help us during our stay in Germany.

My deepest and gratitude is extended to Giselle, Mariana and Yasmin Cattanio, my family, for giving me strength, and for their patience and understanding during my studies. My thanks also to those who have contributed to this dissertation either-way but are not mentioned here. I would like to dedicate my thesis to my family. 


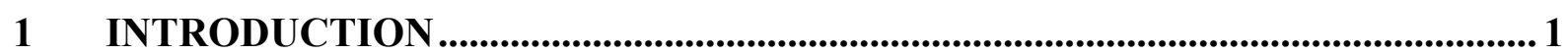

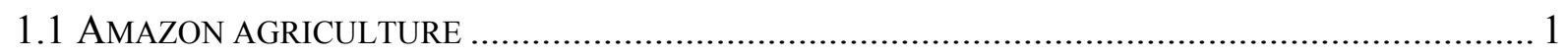

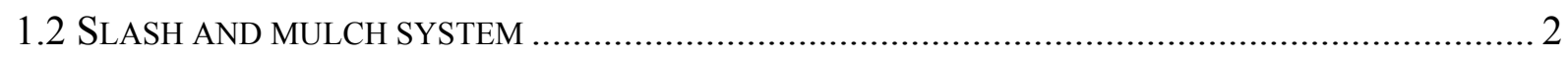

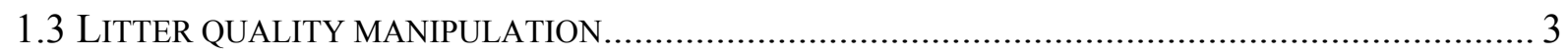

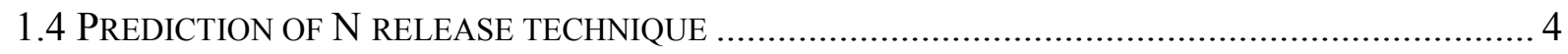

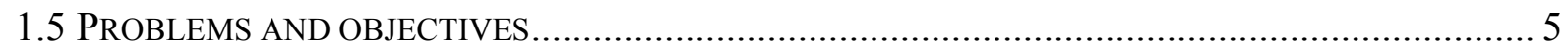

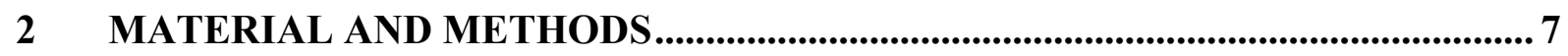

2.1 Pilot STUdy TO DETERMINE CONTRASTING LEGUME DECOMPOSITION …........................... 7

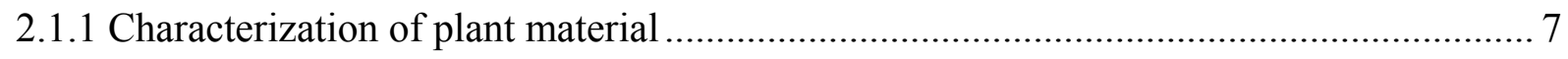

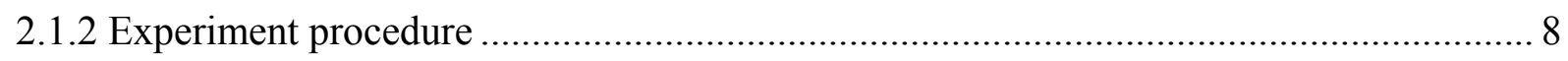

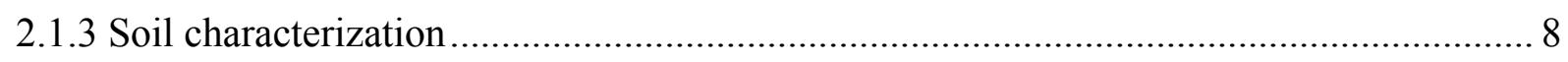

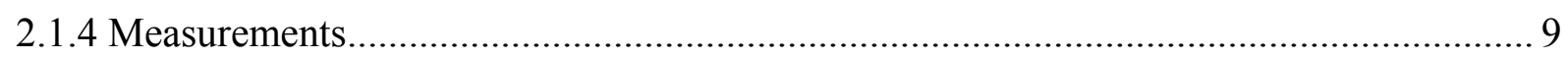

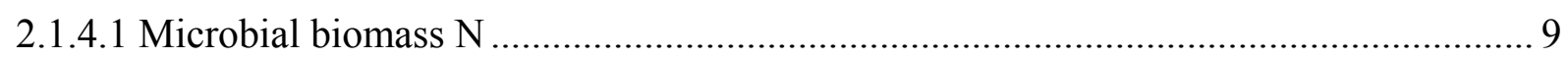

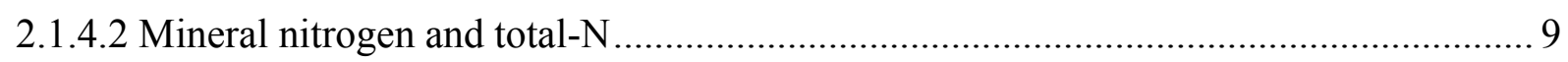

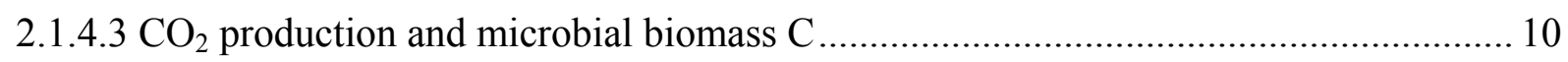

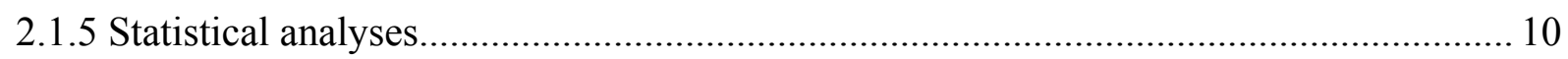

2.2 LABORATORY STUDY WITH CONTRASTING LEGUME LEAF DECOMPOSITION AND GROSS N

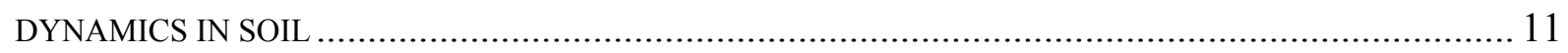

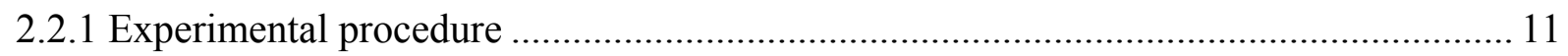

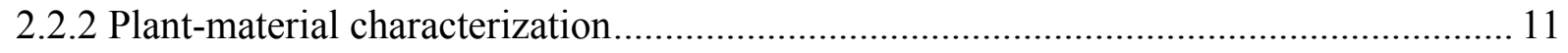

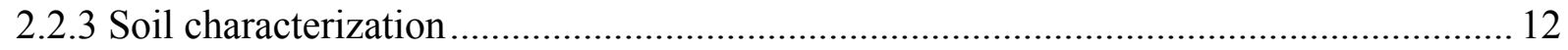

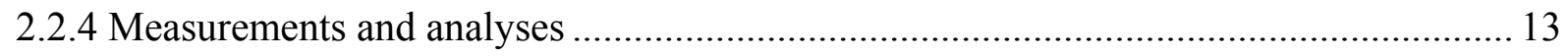

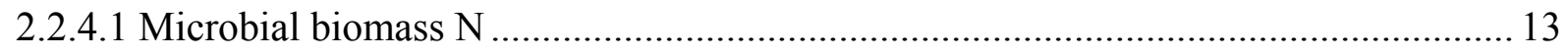

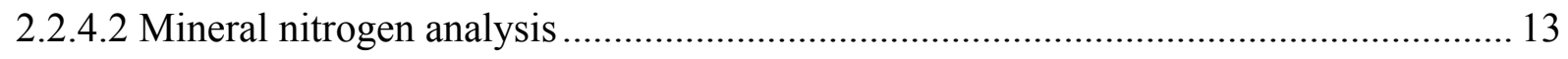

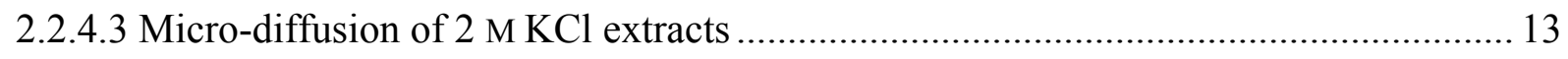

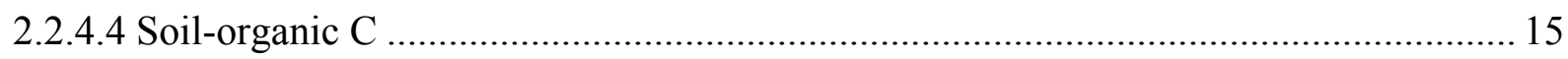


2.3 GREENHOUSE STUDY WITH CONTRASTING LEGUME LEAF DECOMPOSITION AND GROSS N

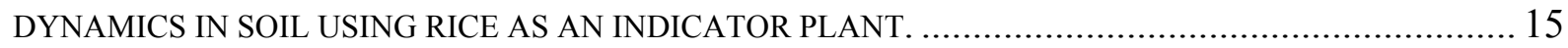

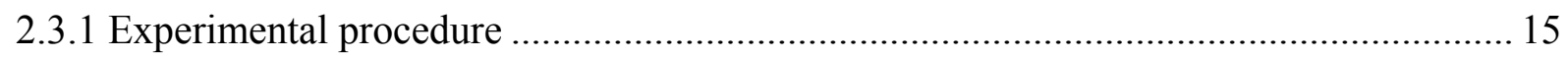

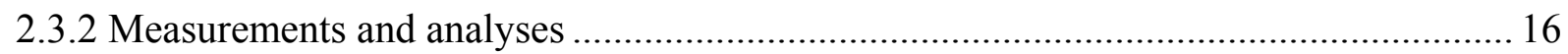

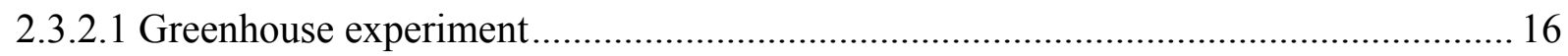

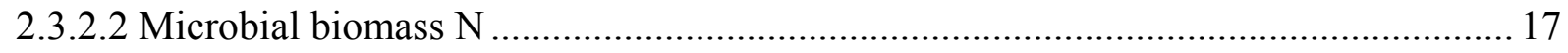

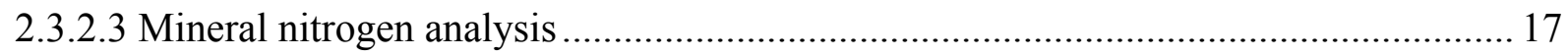

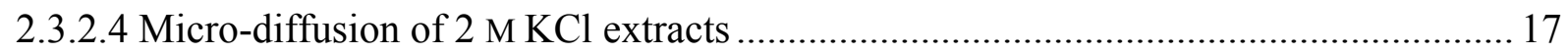

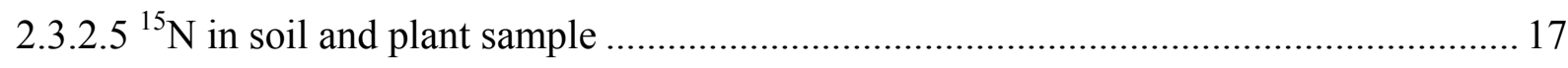

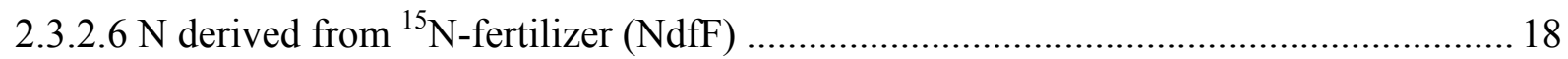

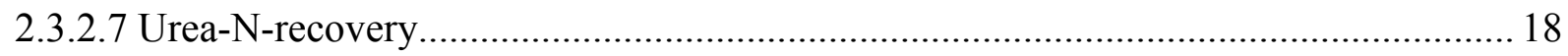

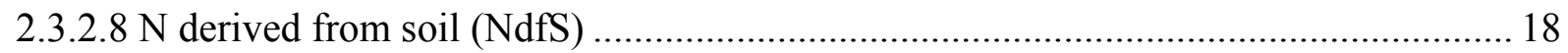

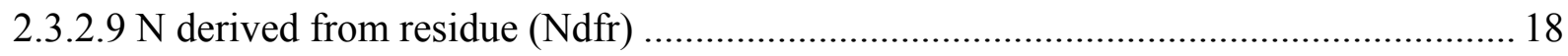

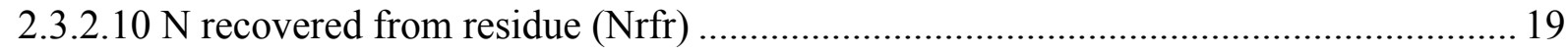

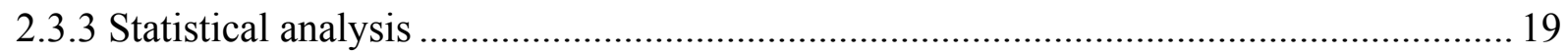

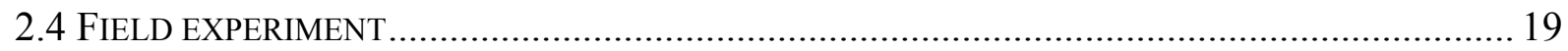

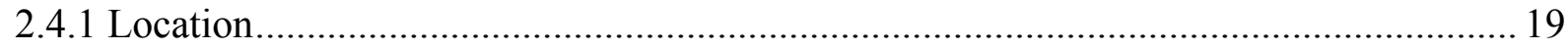

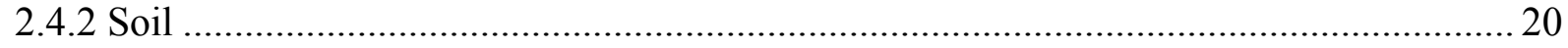

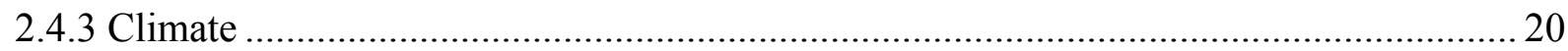

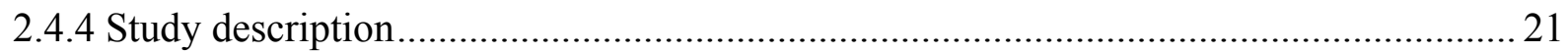

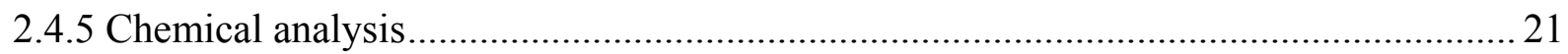

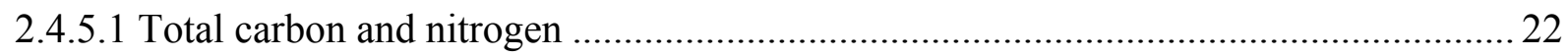

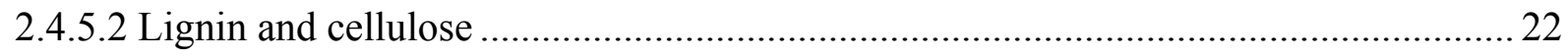

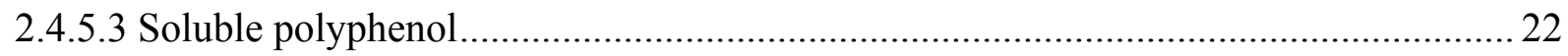

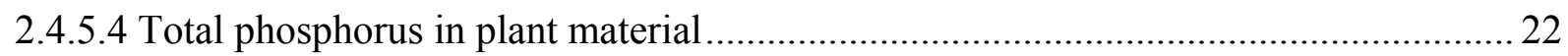

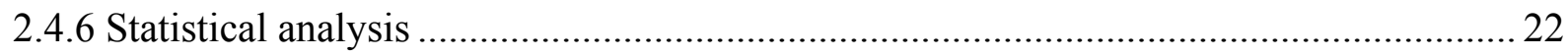

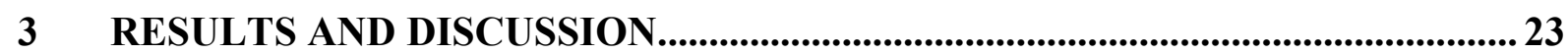


3.1 PILOT STUDY TO IDENTIFY CONTRASTING LEGUMINOUS DECOMPOSITION ON LEAF AND WOOD

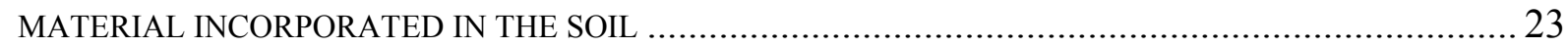

3.1.1 BIOCHEMICAL CHARACTERISTICS OF THE PLANT MATERIALS .......................................... 23

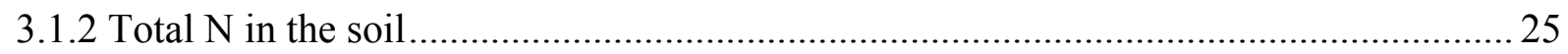

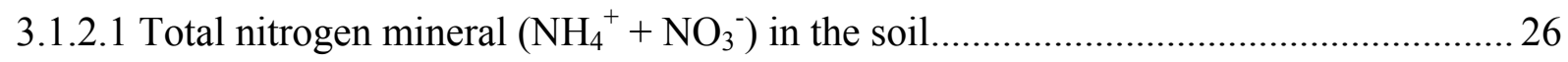

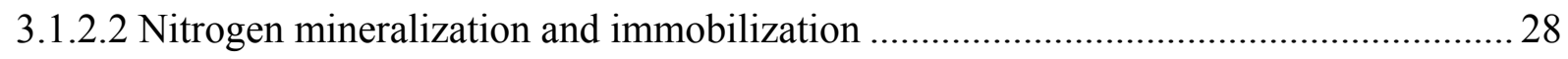

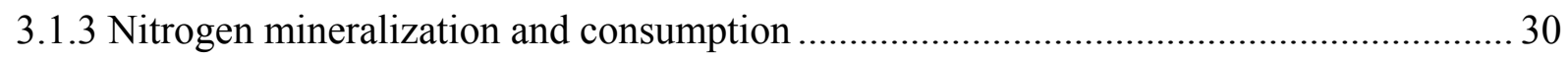

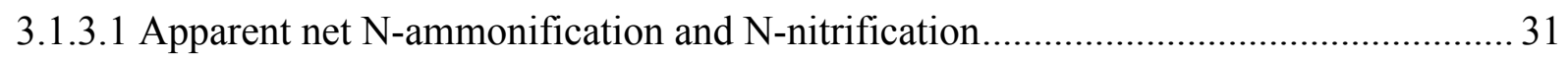

3.1.3.2 Net nitrogen microbial immobilization and consumption....................................... 34

3.1.4 Microbial biomass- $\mathrm{C}$, extractable organic- $\mathrm{C}$, and $\mathrm{CO}_{2}$ production ............................. 38

3.2 LABORATORY STUDY ON DECOMPOSITION AND N DYNAMICS OF CONTRASTING LEGUMINOUS

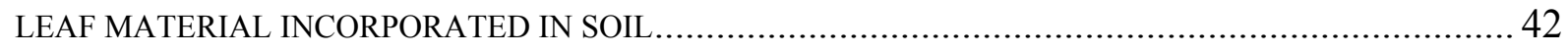

3.2.1 Nitrogen mineralization and immobilization in soil ............................................. 45

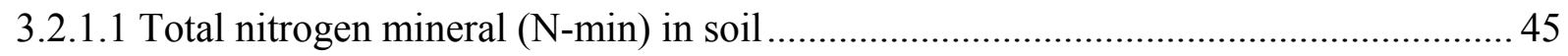

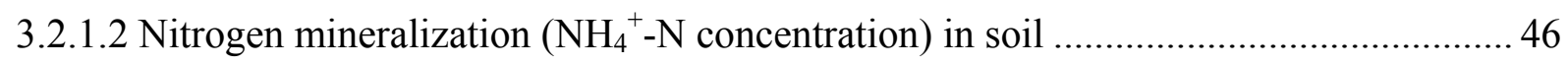

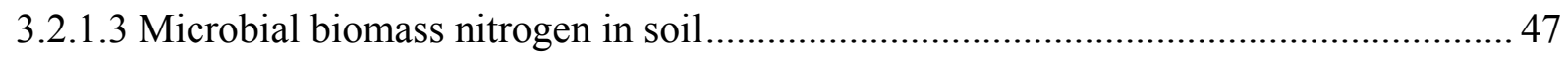

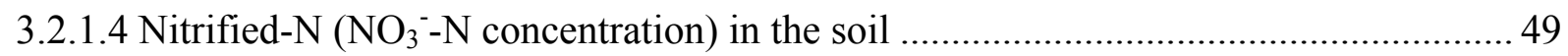

3.2.2 Nitrogen mineralization using ${ }^{14} \mathrm{~N}$-legume leaf material and enriched ${ }^{15} \mathrm{~N}$-urea fertilizers

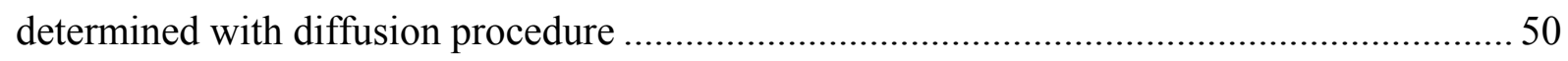

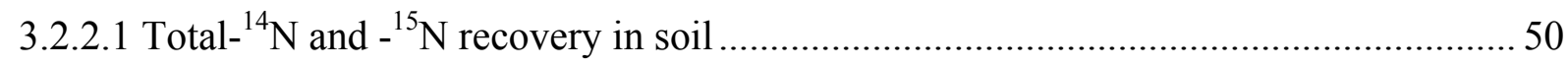

3.2.2.2 Gross $\mathrm{N}$ mineralization, nitrification, and consumption ..................................... 52

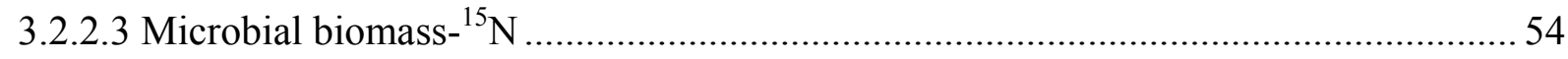

3.2.3 Nitrogen mineralization using enriched ${ }^{15} \mathrm{~N}$-legume leaf material and ${ }^{14} \mathrm{~N}$-urea fertilizer 56

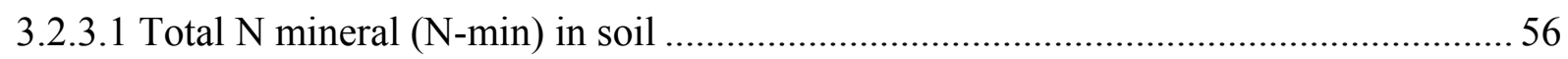

3.2.3.2 Nitrogen mineralization $\left(\mathrm{NH}_{4}{ }^{+}-\mathrm{N}\right.$ concentration) in soil ...................................... 57

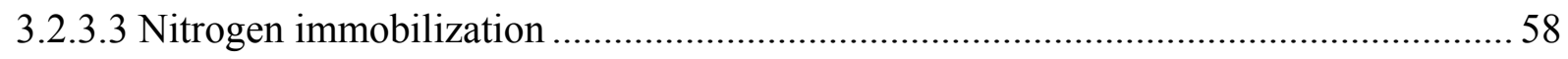

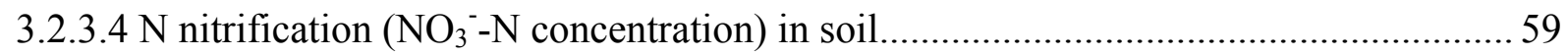




\subsection{GREENHOUSE STUDY ON LEGUMINOUS LEAF DECOMPOSITION AND N DYNAMICS IN SOIL} USING RICE AS AN INDICATOR PLANT

3.3.1 Nitrogen mineralization and immobilization in soil using rice as an indicator plant ..... 67

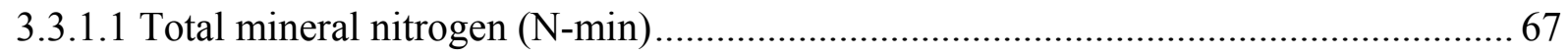

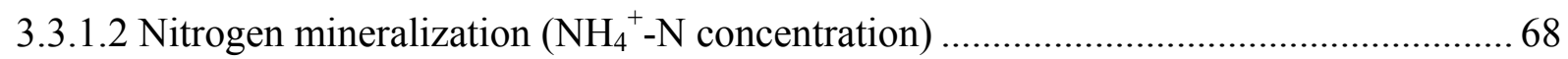

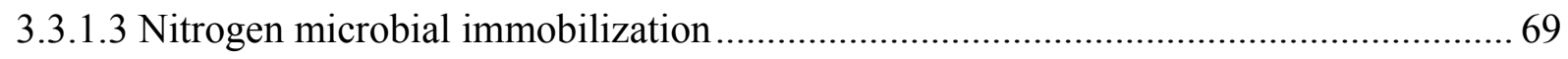

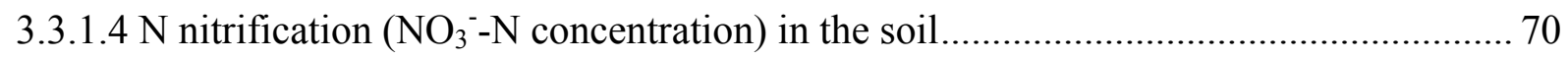

3.3.2 Nitrogen mineralization in soil amended with ${ }^{14} \mathrm{~N}$-legume leaf material and enriched

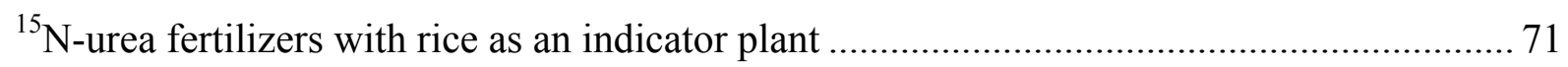

3.3.2.1 Rice biomass and $\mathrm{N}$ content in rice during the greenhouse experiment .................... 71

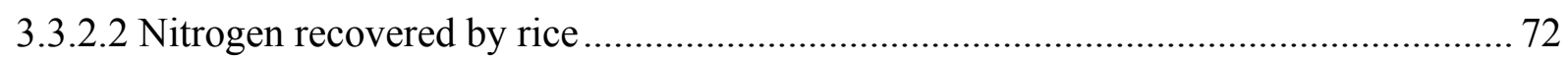

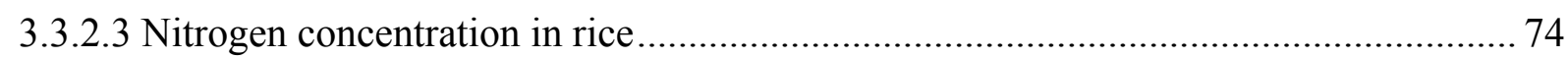

3.3.2.4 Nitrogen derived from fertilizer (NdfF) and from legume leaf material (NdfLM)..... 74

3.3.2.5 ${ }^{15} \mathrm{~N}$-mineral ${ }^{-}$concentration in soil using incorporated ${ }^{14} \mathrm{~N}$-legume leaf material and

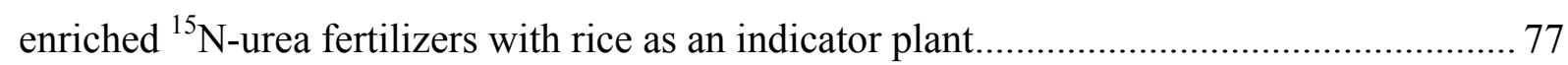

3.3.3 Nitrogen mineralization in soil amended with ${ }^{15} \mathrm{~N}$-legume leaf material and enriched

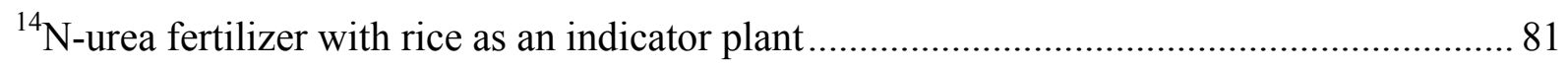

3.3.3.1 Rice biomass and $\mathrm{N}$ content in rice during the greenhouse experiment ..................... 81

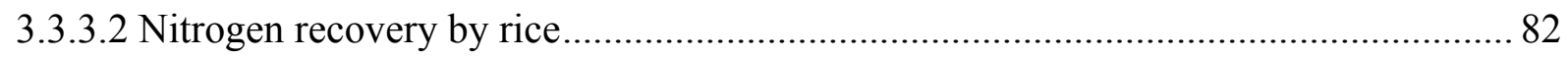

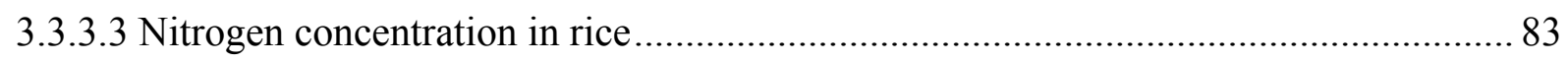

3.3.3.4 Nitrogen derived from residue $(\mathrm{Ndfr})$ and nitrogen recovered from residue $(\mathrm{Nrfr})$.... 84

3.3.3.5 $\mathrm{NH}_{4}{ }^{+}-\mathrm{N}$ and $\mathrm{NO}_{3}{ }^{-}-\mathrm{N}$ concentration and microbial immobilization in soil .................. 86

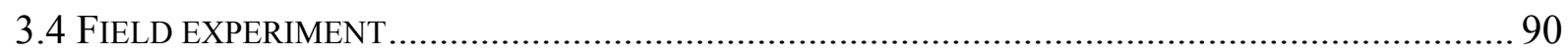

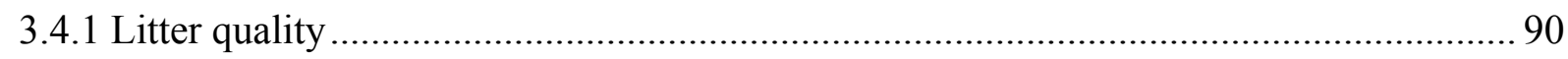

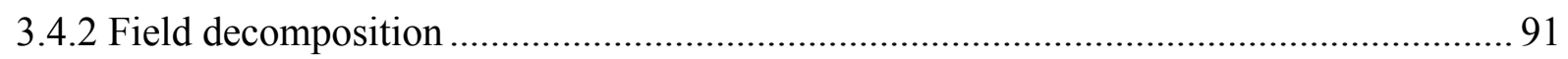

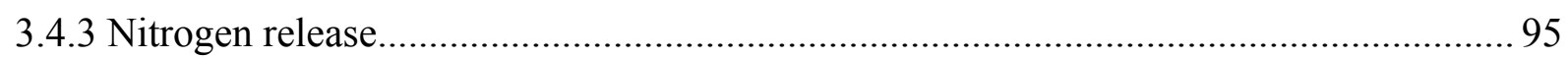

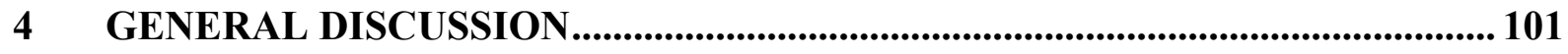


4.1 SOIL INCORPORATED ORGANIC MATTER DECOMPOSITION AND NITROGEN MINERALIZATION AND IMMOBILIZATION. 102

4.2 NitROGEN MINERALIZATION, IMMOBILIZATION AND RICE ABSORPTION.... 104

4.3 FIELD MULCH DECOMPOSITION AND N-MINERALIZATION AND IMMOBILIZATION 104

5 CONCLUSIONS. 106

6 SUMMARY. 108

7 ZUSAMMENFASSUNG 111

8 REFERENCES .. 115 


\section{List of Tables}

Table 1. Amount of soil, legume and mixed leaf amended soil, and the total ${ }^{14} \mathrm{~N}$ and ${ }^{15} \mathrm{~N}$ added with leaf material and fertilizer. The numbers represents mean (standard deviation), with $\mathrm{n}=15$.

Table 2. Amount of organic matter (OM) mixed with soil in a plastic pot and the total ${ }^{14} \mathrm{~N}$ and ${ }^{15} \mathrm{~N}$-excess added with leaf and fertilizer in greenhouse experiment. The numbers represent mean(standard deviation), $\mathrm{n}=12$......

Table 3. Nutrient content (\% dry weight) in leaf and wood of the different legume species used in laboratory decomposition experiment.

Table 4. Initial organic matter added to soil and the nutrient (selected) content and material quality for different treatments in a laboratory incubation experiment. The number represents Mean (standard deviation), with $\mathrm{n}=21$.

Table 5. Total $\mathrm{N}$ content ( $\mathrm{g} \mathrm{N} \mathrm{kg}^{-1}$ soil) for different legume species and mixtures in comparison to fallow and soil without added organic matter during the laboratory decomposition time.

Table 6. Proportion of initially added $\mathrm{N}$ mineralized plus immobilized ${ }^{\alpha}$ from in the leaf + wood material (as $\mathrm{NH}_{4}{ }^{+}-\mathrm{N} \%$ ) for different treatment during the incubation period.

Table 7. Apparent net $\mathrm{N}$-ammonification, $a\left(\mu \mathrm{g} \mathrm{NH}{ }_{4}{ }^{+}-\mathrm{N} \mathrm{g}^{-1} \text { soil }\right)^{\Phi}$ as a function of time for different treatments.

Table 8. Net $\mathrm{N}$ nitrification, $n\left(\mu \mathrm{g} \mathrm{NO}_{3}{ }^{-}-\mathrm{N} \mathrm{g}^{-1}\right.$ soil) ${ }^{\Phi}$ as a function of time for different treatment.

Table 9. Apparent net N-microbial immobilization, $i\left(\mu \mathrm{g} \mathrm{NH}_{4}^{+}-\mathrm{N} \mathrm{g}^{-1} \text { soil }\right)^{\Phi}$ as a function of incubation period and treatment.

Table 10. Apparent Net microbial consumption of $\mathrm{NO}_{3}{ }^{-}-\mathrm{N}, c\left(\mu \mathrm{g} \mathrm{NO}{ }_{3}^{-}-\mathrm{N} \mathrm{g}^{-1} \text { soil }\right)^{\Phi}$ as a function of incubation period and treatment.

Table 11. Correlation coefficients relating the cumulative amount of N-mineralization to initial chemical properties in the treatments.

Table 12. Initial amount of soil (g), leaf amended material $(\mathrm{g})$ with nitrogen content $\left(\mathrm{mg} \mathrm{N} \mathrm{g}^{-1}\right.$ soil), added $\mathrm{N}$-urea chemical fertilizer ( $\mathrm{mg} \mathrm{N} \mathrm{g}^{-1}$ soil), and resulting ${ }^{15} \mathrm{~N}$ excess $\left(\mu \mathrm{g}{ }^{15} \mathrm{~N}\right.$ excess $\mathrm{g}^{-1}$ soil) in soil with different legume treatments and mixtures in laboratory incubation 
experiments. Control was the same soil without organic matter and fertilized with ${ }^{14} \mathrm{~N}$-urea. The numbers represent mean (standard deviation) with $n=15$.

Table 13. Chemical characteristics of leaf material from different legume treatments and plant ages added to soil in laboratory incubation experiment. The numbers represent Mean(Standard deviation) with $\mathrm{n}=15$

Table 14. Proportional $\mathrm{NH}_{4}{ }^{+}-\mathrm{N}(\%)$, mineralized + immobilized, from total initial $\mathrm{N}$ added with leaf material and chemical fertilizer for different treatments during the incubation period, and total accumulative.

Table 15. Total- $\left({ }^{14} \mathrm{~N}+{ }^{15} \mathrm{~N}\right)\left(\mathrm{mg} \mathrm{N} \mathrm{g}^{-1}\right.$ soil) concentration and ${ }^{15} \mathrm{~N}(\%)$ recovery in soil for different ${ }^{14} \mathrm{~N}$-legume treatments with ${ }^{15} \mathrm{~N}$-urea fertilizers during the incubation period (days). The ${ }^{15} \mathrm{~N}$ is expressed as the atom $\%{ }^{15} \mathrm{~N}$ excess abundance above the background $(0.3663$ atom $\%)$

Table 16. Gross rates of $\mathrm{N}$ mineralization, consumption, and nitrification ( $\mu \mathrm{g} \mathrm{N} \mathrm{g}^{-1}$ soil day ${ }^{-1}$ ) in soil with different legume leaf amendments determined through ${ }^{15} \mathrm{~N}$ isotopic pool dilution (Equation 6 and 7).

Table 17. Estimation of gross $\mathrm{NH}_{4}{ }^{+}$-immobilization $\left(\mu \mathrm{g} \mathrm{N} \mathrm{g}^{-1}\right.$ soil day $\left.{ }^{-1}\right)$ in soil with different legume leaf amendments determined through ${ }^{15} \mathrm{~N}$ isotopic pool dilution. 54

Table 18. Total- $\left({ }^{14} \mathrm{~N}+{ }^{15} \mathrm{~N}\right)\left(\mathrm{mg} \mathrm{N} \mathrm{g}^{-1}\right.$ soil) concentration and ${ }^{15} \mathrm{~N}$ recovery in soil for different ${ }^{15} \mathrm{~N}$-legume treatment and fertilized with ${ }^{14} \mathrm{~N}$-urea during the incubation period. ${ }^{15} \mathrm{~N}$ is expressed as the atom $\%{ }^{15} \mathrm{~N}$ excess abundance above the background $(0.3663$ atom $\%)$...... 56 Table 19. Diffusion procedure and total N-mineral in soil with different treatments of added ${ }^{14 a n d}{ }^{15} \mathrm{~N}$-legume leaf material and fertilized with ${ }^{15}$ and ${ }^{14} \mathrm{~N}$-urea, respectively. Control was soil without organic amendment and fertilized with ${ }^{14} \mathrm{~N}$-urea. The numbers represent mean(Standard error). The ${ }^{15} \mathrm{~N}$ is expressed as the atom $\%{ }^{15} \mathrm{~N}$ excess abundance above the background $(0.3663$ atom $\%)$.

Table $20 .{ }^{15} \mathrm{~N}$ (diffusion procedure) and total microbial biomass-N in soil with different treatments of added ${ }^{14} \mathrm{~N}$ - and ${ }^{15} \mathrm{~N}$-legume leaf material and fertilized with ${ }^{15}$ and ${ }^{14} \mathrm{~N}$-urea, respectively. Control was soil without added organic matter and fertilized with ${ }^{14} \mathrm{~N}$-urea. The numbers represent mean (Standard error of the mean). The ${ }^{15} \mathrm{~N}$ is expressed as the atom $\%$ ${ }^{15} \mathrm{~N}$ excess abundance above the background (0.3663 atom \%). 64

Table 21. Initial amount of soil (g), leaf-amended material $(\mathrm{g})$ with nitrogen content $\left(\mathrm{mg} \mathrm{N} \mathrm{g}^{-1}\right.$ soil), added urea- $\mathrm{N}$ (mg N g ${ }^{-1}$ soil), and resulting ${ }^{15} \mathrm{~N}$ excess ( $\mu \mathrm{g}{ }^{15} \mathrm{~N}$ excess $\mathrm{g}^{-1}$ soil) in the soil 
of different legume treatments in the greenhouse incubation experiment. Control was the same soil without added organic matter and fertilized with ${ }^{14} \mathrm{~N}$-urea. The numbers represent Mean (Standard deviation) with $\mathrm{n}=12$. The ${ }^{15} \mathrm{~N}$ excess is expressed as the atom $\%{ }^{15} \mathrm{~N}$ excess abundance above the background (0.3663 atom \%).

Table 22. Chemical characteristics of leaf material from different legume species added to soil in laboratory incubation experiment. The number represents Mean(Standard deviation) with $\mathrm{n}$ $=12$. 67

Table 23. Nitrogen concentration ( $\mathrm{mg} \mathrm{N} \mathrm{g}^{-1}$ dry matter) for different treatment and the control during the incubation time (days). Control was soil without added leaf material. 74

Table 24. Nitrogen derived from fertilizer (NdfF) and nitrogen derived from added leaf material (NdfLM) in rice during the greenhouse study with different leaf legume treatments incorporated in the soil.

Table 25. Total $\mathrm{NH}_{4}{ }^{+}-\left({ }^{14} \mathrm{~N}+{ }^{15} \mathrm{~N}\right)\left(\mu \mathrm{g} \mathrm{N} \mathrm{g}{ }^{-1}\right.$ soil $)$ and $\mathrm{NH}_{4}{ }^{+}{ }^{15} \mathrm{~N}\left(\mu \mathrm{g}{ }^{15} \mathrm{Ng}^{-1}\right.$ soil $)$ excess in soil with different added ${ }^{14} \mathrm{~N}$-leaf legume material and ${ }^{15} \mathrm{~N}$-urea as fertilizer with rice as an indicator plant. Control was soil without added leaf material and fertilized with ${ }^{14} \mathrm{~N}$-urea. ${ }^{15} \mathrm{~N}$ excess is expressed as the atom $\%{ }^{15} \mathrm{~N}$ excess abundance above the background $(0.3663$ atom $\%)$. 78

Table 26. Total $\mathrm{NO}_{3}-{ }_{-}^{-}\left({ }^{14} \mathrm{~N}+{ }^{15} \mathrm{~N}\right)\left(\mu \mathrm{g} \mathrm{N} \mathrm{g}{ }^{-1}\right.$ soil $)$ and $\mathrm{NO}_{3}{ }^{-}{ }^{-15} \mathrm{~N}\left(\mu \mathrm{g}{ }^{15} \mathrm{Ng}^{-1}\right.$ soil $)$ excess in soil amended with legume leaf material and ${ }^{15} \mathrm{~N}$-urea as fertilizer with rice as an indicator plant. Control was soil without added leaf material and fertilized with $\mathrm{N}$-urea. ${ }^{15} \mathrm{~N}$ excess is expressed as the atom $\%{ }^{15} \mathrm{~N}$ excess abundance above the background $(0.3663$ atom $\%)$...... 79 Table 27. Microbial biomass $-\left({ }^{14} \mathrm{~N}+{ }^{15} \mathrm{~N}\right)\left(\mu \mathrm{g}{ }^{14} \mathrm{~N}+{ }^{15} \mathrm{~N} \mathrm{~g}-1\right.$ soil) and microbial biomass $-{ }^{15} \mathrm{~N}(\mu \mathrm{g}$ ${ }^{15} \mathrm{~N} \mathrm{~g}^{-1}$ soil) in soil amended with legume- ${ }^{14} \mathrm{~N}$ leaf material and enriched urea- ${ }^{15} \mathrm{~N}$ fertilizer with rice as an indicator plant. The ${ }^{15} \mathrm{~N}$ is expressed as the atom $\%{ }^{15} \mathrm{~N}$ excess abundance above the background $(0.3663$ atom $\%)$...

Table 28. Nitrogen concentration ( $\mathrm{mg} \mathrm{N} \mathrm{g}^{-1}$ dry matter) for different treatment and control during the incubation time (days). Control was soil without added leaf material and fertilized with N-urea.

Table 29. Nitrogen derived from residue (NdfR) in \% and $\mathrm{mg}$, and $\mathrm{N}$ recovered from residue $(\mathrm{NrfR}, \%)$ during the greenhouse incubation period in soil treated with ${ }^{15} \mathrm{~N}$-leaf legume and ${ }^{14} \mathrm{~N}$-urea fertilizer. 
Table 30. Total $\mathrm{NH}_{4}{ }^{+}-\left({ }^{14} \mathrm{~N}+{ }^{15} \mathrm{~N}\right)\left(\mu \mathrm{g} \mathrm{N} \mathrm{g}{ }^{-1}\right.$ soil) and excess $\mathrm{NH}_{4}{ }^{+}-{ }^{15} \mathrm{~N}\left(\mu \mathrm{g}{ }^{15} \mathrm{Ng}^{-1}\right.$ soil) in soil amended with different ${ }^{15} \mathrm{~N}$-leaf legume material and ${ }^{14} \mathrm{~N}$-urea as fertilizer with rice as an indicator plant. Control soil as was only fertilized with ${ }^{14} \mathrm{~N}$-urea. The ${ }^{15} \mathrm{~N}$ excess is expressed as the atom $\%{ }^{15} \mathrm{~N}$ excess abundance above the background (0.3663 atom \%).

Table 31. Total $\mathrm{NO}_{3}{ }^{-} \mathrm{N}\left(\mu \mathrm{g} \mathrm{N} \mathrm{g}{ }^{-1}\right.$ soil) and excess $\mathrm{NO}_{3}{ }_{-}^{-15} \mathrm{~N}\left(\mu \mathrm{g}{ }^{15} \mathrm{Ng}^{-1}\right.$ soil) in soil amended with different ${ }^{15} \mathrm{~N}$-leaf legume material and ${ }^{14} \mathrm{~N}$-urea as fertilizer with rice as an indicator plant. Control was soil without added leaf material and fertilized with $\mathrm{N}$-urea. The ${ }^{15} \mathrm{~N}$ excess is expressed as the atom $\%{ }^{15} \mathrm{~N}$ excess abundance above the background ( 0.3663 atom \%). . 88 Table 32. $\left({ }^{14} \mathrm{~N}+{ }^{15} \mathrm{~N}\right)$-microbial biomass $\left(\mu \mathrm{g}{ }^{14} \mathrm{~N}+{ }^{15} \mathrm{Ng}^{-1}\right.$ soil $)$ and ${ }^{15} \mathrm{~N}$-microbial biomass $(\mu \mathrm{g}$ ${ }^{15} \mathrm{~N}$ excess $\mathrm{g}^{-1}$ soil) in soil amended with ${ }^{14} \mathrm{~N}$-legume leaf material and enriched ${ }^{15} \mathrm{~N}$-urea fertilizer with rice as an indicator plant. Control was soil without added leaf material and fertilized with $\mathrm{N}$-urea. The ${ }^{15} \mathrm{~N}$ excess is expressed as the atom $\%{ }^{15} \mathrm{~N}$ excess abundance above the background $(0.3663$ atom $\%)$......

Table 33. Initial chemical composition of litter bag material from different leguminous species and control (natural fallow vegetation) used in the decomposition experiment at Igarapé-Açú, Brazil.

Table 34. Estimated values of parameters of decomposition model (Equation 3) fitted to data of different leguminous species.

Table 35. The proportion of remaining material (\%) at different sampling times (days) for 5 leguminous species and the control (fallow vegetation) as affected by placing on bare soil ($\mathrm{OM})$ and burying below a thick mulch layer (+OM).

Table 36. N remaining (\%), during the decomposition of 5 leguminous species and a control (fallow vegetation) as affected by exposure on surface soil and burial under a thick mat of mulch $(+\mathrm{OM})$

Table 37. Coefficients of determination $\left(r^{2}\right)$ for linear regressions between initial substrate quality variables from five legumes species and natural fallow vegetation (as control) and Nmineralization rate constants after one year of field decomposition. The variables were selected by being more frequently cited in the revised literature.

Table 38. Nitrogen-mineral ${ }^{\Phi}\left(\mu \mathrm{g} \mathrm{N} \mathrm{g}^{-1}\right.$ soil) and N-microbial biomass ${ }^{\Psi}$ ( $\mu \mathrm{g} \mathrm{N} \mathrm{g}^{-1}$ soil) for incorporated leaf + wood material in comparison with incorporated leaf material + Urea as fertilizer, during the incubation time and total. The numbers represent mean (Standard error). 


\section{List of Figures}

Figure 1. Map of the northeast of Pará State, Brazil, with Igarapé-Açú region in highlight. .. 20

Figure 2. Soil inorganic $\mathrm{N}$ concentration as affected by incorporated wood and leaves from different legumes species in comparison with fallow vegetation (Fallow) and soil with initial organic matter. In all graphics the $\mathrm{m}^{*} \mathrm{e}$ and $\mathrm{p} *$ a symbol correspond to A. mangium and $I$. edulis mixture (50:50 w/w), and A. angustissima and S. paniculatum mixture (50:50 w/w), respectively. Bars represent standard error of the mean.

Figure 3. Concentration of mineral $\mathrm{N}$ as influenced by incorporated wood and leaves from different legumes species in comparison with fallow vegetation (Fallow) and soil with initial organic matter (Soil) as control. Bars represent standard error of the mean.

Figure 4. Flows of soil nitrogen indicated by: $(a)$ apparent $\mathrm{N}$-ammonification, $(r)$ apparent $\mathrm{N}$ remineralization, (n) apparent $\mathrm{N}$-nitrification, $(i)$ apparent $\mathrm{NH}_{4}^{+}{ }_{4} \mathrm{~N}$ immobilization, $(c)$ apparent $\mathrm{N}-\mathrm{NO}_{3}^{-}$consumption, $(d)$ denitrification. Adapted from Stark and Schimel (2001).

Figure 5. (A) Net ammonification of different legume residue-derived $\mathrm{N}$ in comparison to fallow residue-derived N. (B) Net nitrification of different legumes and mixture of residuesderived $\mathrm{N}$ in comparison to fallow residue-derived N. Bars represent LSD.

Figure 6. (A) $\mathrm{NH}_{4}{ }^{+}-\mathrm{N}$ microbial immobilization $\left(\mu \mathrm{g} \mathrm{NH}{ }_{4}^{+}-\mathrm{N} \mathrm{g}^{-1}\right.$ soil) and (B) apparent $\mathrm{NO}_{3}{ }^{-}-$ $\mathrm{N}$ microbial consumption in soil of different legumes and mixtures, of leaf and wood material incorporated in soil, during the decomposition period. 36

Figure 7. (A) Total microbial biomass $\mathrm{C}\left(\mu \mathrm{g} \mathrm{C} \mathrm{g}^{-1}\right.$ soil) and (B) Extractable Organic carbon ( $\mu \mathrm{g} \mathrm{C} \mathrm{g}^{-1}$ soil) in soil with different legumes and mixture, of leaf and wood material incorporated in soil, during the decomposition period. Bars represent LSD.

Figure 8. Accumulative $\mathrm{C}-\mathrm{CO}_{2}\left(\mu \mathrm{g} \mathrm{C} \mathrm{g}^{-1}\right.$ soil day $\left.{ }^{-1}\right)$ production during the incubation period for treatments with different organic matter soil added in comparison with soil without added organic matter as control (Soil).

Figure 9. The relationship between mineral $\mathrm{N}(\mathrm{N}-\mathrm{min})$ and the extractable organic $\mathrm{C}$ resulting from treatment with different legumes, mixture and fallow at the end of incubation period (128 days). The symbols correspond to Fallow (०), A. angustissima $(\times)$, A. mangium (*), $\mathrm{p}^{* a}$

mixture $(\bullet)$, I. edulis $(\square)$, m*e mixture $(\Delta)$, S. paniculatum $(\triangle)$ treatment. 40 
Figure 10. (A) Total nitrogen mineralization $\left(\mu \mathrm{g}\left({ }^{14} \mathrm{~N}+{ }^{15} \mathrm{~N}\right)-\mathrm{Nmin} \mathrm{g}^{-1}\right.$ soil) during the laboratory incubation period (days) for samples with ${ }^{14} \mathrm{~N}$ leaf material and fertilized with enriched ${ }^{15} \mathrm{~N}$-urea $\left({ }^{14}\right.$ after species name), and (B) samples with ${ }^{15} \mathrm{~N}$ enriched leaf material and fertilized with ${ }^{14} \mathrm{~N}$-urea $\left({ }^{15}\right.$ after species name). Soil control was soil without leaf material and

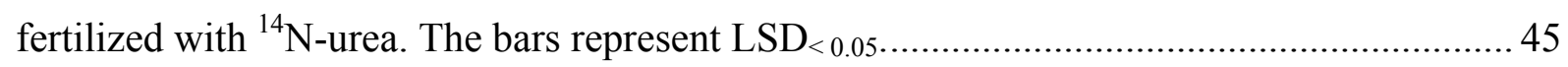

Figure 11. (A) Total N-mineralization $\left(\mu \mathrm{g} \mathrm{NH}_{4}{ }^{+}-\mathrm{N} \mathrm{g}^{-1}\right.$ soil) during the laboratory incubation (days) for samples with ${ }^{14} \mathrm{~N}$ leaf material and fertilized with enriched ${ }^{15} \mathrm{~N}$-urea $\left({ }^{14}\right.$ after species name), and (B) samples with ${ }^{15} \mathrm{~N}$ enriched leaf material and fertilized with ${ }^{14} \mathrm{~N}$-urea $\left({ }^{15}\right.$ after species name). Soil control was soil without added leaf material and fertilized with ${ }^{14} \mathrm{~N}$-urea. The bars represent $\operatorname{LSD}_{\mathrm{P}}<0.05$.....

Figure 12. (A) Nitrogen microbial biomass $\left(\mu \mathrm{g} \mathrm{NH}{ }_{4}{ }^{+}-\mathrm{N} \mathrm{g}^{-1}\right.$ soil) during the laboratory incubation period (days) for samples with ${ }^{14} \mathrm{~N}$ leaf material and fertilized with enriched ${ }^{15} \mathrm{~N}$ urea ( ${ }^{14}$ after species name), (B) and samples with ${ }^{15} \mathrm{~N}$ enriched leaf material and fertilized with ${ }^{14} \mathrm{~N}$-urea ( ${ }^{15}$ after species name). Control was soil without added leaf material and

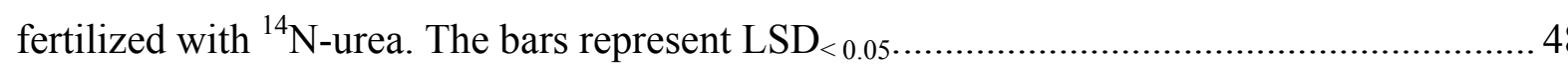

Figure 13. (A) Nitrification ( $\mu \mathrm{g} \mathrm{NO}_{3}{ }^{-}-\mathrm{N} \mathrm{g}^{-1}$ soil) during the laboratory incubation period (days) for samples with ${ }^{14} \mathrm{~N}$ leaf material and fertilized with enriched ${ }^{15} \mathrm{~N}$-urea $\left({ }^{14}\right.$ after species name), and (B) samples with ${ }^{15} \mathrm{~N}$ enriched leaf material and fertilized with ${ }^{14} \mathrm{~N}$-urea $\left({ }^{15}\right.$ after species name). Control was soil without added leaf material and fertilized with ${ }^{14} \mathrm{~N}$-urea. The bars represent $\mathrm{LSD}_{<0.05}$.

Figure 14. (A) Total $\left({ }^{14} \mathrm{~N}+{ }^{15} \mathrm{~N}\right)$-microbial biomass and (B) total ${ }^{15} \mathrm{~N}$-microbial biomass excess during the incubation period for different treatments of legume leaf material incorporated in the soil estimated by micro-diffusion analysis. The bars represent standard error of the mean. The ${ }^{15} \mathrm{~N}$ excess is expressed as the atom $\%{ }^{15} \mathrm{~N}$ excess abundance above the background $(0.3663$ atom \%).

Figure 15. (A) Total $\left({ }^{14} \mathrm{~N}+{ }^{15} \mathrm{~N}\right)$-mineral and (B) total ${ }^{15} \mathrm{~N}$-mineralization during the incubation period for different treatments with legume leaf material incorporated in soil determined by micro-diffusion analysis. The bars represent $\mathrm{LSD}_{<0.05}$. The ${ }^{15} \mathrm{~N}$ is expressed as the atom $\%$ ${ }^{15} \mathrm{~N}$ excess abundance above the background (0.3663 atom \%).

Figure 16. (A) Total $\mathrm{NH}_{4}{ }^{+}-\left({ }^{14} \mathrm{~N}+{ }^{15} \mathrm{~N}\right)$ and (B) total $\mathrm{NH}_{4}{ }^{+}-{ }^{15} \mathrm{~N}$ during the incubation period for different treatments of soil amended with legume leaf material, determined by micro-diffusion analysis. The bars represent $\mathrm{LSD}_{<0.05}$. The ${ }^{15} \mathrm{~N}$ is expressed as the atom $\%{ }^{15} \mathrm{~N}$ excess abundance above the background (0.3663 atom \%). 
Figure 17. (A) Total $\left({ }^{14} \mathrm{~N}+{ }^{15} \mathrm{~N}\right)$-microbial biomass and (B) total ${ }^{15} \mathrm{~N}$-microbial biomass during the incubation period for different treatments with soil amended with legume leaf material determined by micro-diffusion analysis. The bars represent $\mathrm{LSD}_{<0.05}$. The ${ }^{15} \mathrm{~N}$ is expressed as the atom $\%{ }^{15} \mathrm{~N}$ excess abundance above the background $(0.3663$ atom $\%)$.

Figure 18. (A) Total $\mathrm{NO}_{3}-\left({ }^{-}\left({ }^{14} \mathrm{~N}+{ }^{15} \mathrm{~N}\right)\right.$ and (B) total $\mathrm{NO}_{3}-{ }_{-}^{-15} \mathrm{~N}$ during the incubation period for different treatments of soil amended with legume leaf material soil determined by microdiffusion analysis. The bars represent $\mathrm{LSD}_{<0.05}$. The ${ }^{15} \mathrm{~N}$ is expressed as the atom $\%{ }^{15} \mathrm{~N}$ excess abundance above the background (0.3663 atom \%).

Figure 19. (A) Total nitrogen mineralization $\left(\mu \mathrm{g}{ }^{14} \mathrm{~N}+{ }^{15} \mathrm{~N}-\mathrm{min}^{-1}\right.$ soil) during the greenhouse incubation period (days) for samples with ${ }^{14} \mathrm{~N}$ leaf material and fertilized with enriched ${ }^{15} \mathrm{~N}$ urea $\left({ }^{14}\right.$ after species name), (B) and samples with ${ }^{15} \mathrm{~N}$ enriched leaf material and fertilized with ${ }^{14} \mathrm{~N}$-urea ( ${ }^{15}$ after species name). Soil as control was soil without leaf material and fertilized with ${ }^{14} \mathrm{~N}$-urea. The bars represent $\mathrm{LSD}_{<0.05}$

Figure 20. (A) Nitrogen mineralization $\left(\mu \mathrm{g} \mathrm{NH}_{4}{ }^{+}-\mathrm{N} \mathrm{g}^{-1}\right.$ soil) during the greenhouse incubation period (days) for samples with ${ }^{14} \mathrm{~N}$ leaf material and fertilized with enriched ${ }^{15} \mathrm{~N}$-urea $\left({ }^{14}\right.$ after species name), (B) and samples with ${ }^{15} \mathrm{~N}$ enriched leaf material and fertilized with ${ }^{14} \mathrm{~N}$-urea $\left({ }^{15}\right.$ after species name). Control was soil without added leaf material and fertilized with ${ }^{14} \mathrm{~N}$-urea. The bars represent $\mathrm{LSD}_{<0.05}$.

Figure 21. (A) Nitrogen microbial biomass $\left(\mu \mathrm{g} \mathrm{NH}_{4}{ }^{+}-\mathrm{N} \mathrm{g}^{-1}\right.$ soil) during the greenhouse incubation period (days) for samples with ${ }^{14} \mathrm{~N}$ leaf material and fertilized with enriched urea${ }^{15} \mathrm{~N}\left({ }^{14}\right.$ after species name), (B) and samples with ${ }^{15} \mathrm{~N}$ enriched leaf material and fertilized with urea- ${ }^{14} \mathrm{~N}$ ( ${ }^{15}$ after species name). Soil treatment (as control) was soil without added leaf material and fertilized with urea- ${ }^{14} \mathrm{~N}$. The bars represent Standard error of the mean. 70

Figure 22. (A) Nitrification ( $\mu \mathrm{g} \mathrm{NO}_{3}{ }^{-}-\mathrm{N} \mathrm{g}^{-1}$ soil) during the greenhouse incubation period (days) for samples with ${ }^{14} \mathrm{~N}$ leaf material and fertilized with enriched urea- ${ }^{15} \mathrm{~N}\left({ }^{14}\right.$ after species name), and (B) samples with ${ }^{15} \mathrm{~N}$ enriched leaf material and fertilized with urea- ${ }^{14} \mathrm{~N}\left({ }^{15}\right.$ after species name). Soil treatment (as control) was soil without added leaf material and fertilized

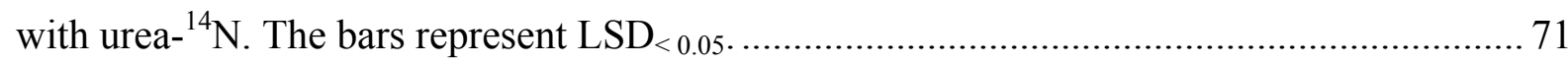
Figure 23. Rice dry matter (g pot ${ }^{-1}$, boxes) and total $\mathrm{N}$ in plant material (mg N pot ${ }^{-1}$, lines) growing in soil with leaf- ${ }^{14} \mathrm{~N}$ legume material and mixture using enriched urea- ${ }^{15} \mathrm{~N}$ fertilizer. Control was soil that only included urea- ${ }^{14} \mathrm{~N}$ fertilizer. Bars represent standard error of the mean. 
Figure $24 .{ }^{14} \mathrm{~N}+{ }^{15} \mathrm{~N}$ and ${ }^{15} \mathrm{~N}$ recovery by rice in soil amended with ${ }^{14} \mathrm{~N}$-leaf material from two different legumes species and mixture with ${ }^{15} \mathrm{~N}$-urea fertilizer in comparison with soil without leaf material and fertilized with $\mathrm{N}$-urea (Control), for different incubation periods. The ${ }^{15} \mathrm{~N}$ is expressed as the atom $\%{ }^{15} \mathrm{~N}$ excess abundance above the background $(0.3663$ atom $\%)$..... 73 Figure 25. Dry matter (g pot ${ }^{-1}$, boxes) and total $\mathrm{N}$ in plant material ( $\mathrm{mg} \mathrm{N} \operatorname{pot}^{-1}$, lines) for rice growing in soil with ${ }^{14} \mathrm{~N}$-legume leaf material or a mixture using enriched urea ${ }^{15} \mathrm{~N}$ fertilizer. Soil as control was only treated with urea ${ }^{14} \mathrm{~N}$ fertilizer. Bars represent standard error of the mean.

Figure 26. ${ }^{14} \mathrm{~N}+{ }^{15} \mathrm{~N}$ recovery and ${ }^{15} \mathrm{~N}$ in rice for treatment of soil with ${ }^{15} \mathrm{~N}$-leaf material of two different legumes species and species mixture and ${ }^{14} \mathrm{~N}$-urea fertilizer in comparison with soil without added leaf material and fertilized with ${ }^{15} \mathrm{~N}$-urea, for different incubation periods. The ${ }^{15} \mathrm{~N}$ is expressed as the atom $\%{ }^{15} \mathrm{~N}$ excess abundance above the background $(0.3663$ atom \%).

Figure 27. Observed (points) and fitted (lines) decomposition curves for five-legume species and fallow vegetation (as control). Bars represent Standard error of the mean. Exp. 1 (Equation 15) and 2 (Equation 16) means single and double exponential model, respectively.

Figure 28. Remaining $\mathrm{N}$ and $\mathrm{C}(\%)$ in litter bags material during decomposition for five leguminous species and a fallow vegetation (control), in Igarapé-Açú, Brazil (Bars represent standard error of the mean).

Figure 29. Linear regression coefficients indicating predicted N-release from decomposition of five different leguminous trees and control (Fallow vegetation). 


\section{List of Abbreviations}

ADF

ANOVA

$\mathrm{B}_{\mathrm{N}}$

$\mathrm{BNF}$

DM

GLM

IITA

$\mathrm{k}$

LSD

$\mathrm{NdfF}$

NdfLM

Ndfr

NdfS

$\mathrm{Nrfr}$

$\mathrm{NrR}$

$\mathrm{NrS}$

$\mathrm{OM}$

PTFE

PVC

$\mathrm{r}^{2}$

SHIFT project

SOM

USDA

UV-radiation

WHC

Acid detergent fiber

Analyses of variance

Microbial biomass nitrogen

Biological nitrogen fixation

Dry matter

General linear model

International Institute of Tropical Agriculture

Rate constant

Least significant difference

$\mathrm{N}$ derived from ${ }^{15} \mathrm{~N}$-fertilizer

Nitrogen derived from added leaf material

$\mathrm{N}$ derived from residue

$\mathrm{N}$ derived from soil

$\mathrm{N}$ recovered from residue

$\mathrm{N}$ recovery by rice

Total recovery within the system

Organic matter

Polytetrafluoroethylene pipe-sealing tape

Polyvinyl chloride

Coefficients of determination

Study of Human Impact on Forest and Floodplains in the Tropics

Soil organic matter

United States Department of Agriculture

Ultraviolet radiation

Water-holding capacity 


\section{INTRODUCTION}

Soil serves a range of different functions that can sometimes conflict. It is the basis for agriculture and forestry and the importance of this role will increase with the expected a population of 80-10 billion by 2050 (Fischer and Heilig 1998). These increases in food demands needs cannot be met by a major expansion the area under cultivation so intensification and improvement of currently managed land is unavoidable.

\subsection{Amazon agriculture}

In Amazon human activities such as slashing and burning converted large areas of primary forest to temporarily used agricultural land. Thus, the fallow vegetation, which is dominated by secondary forest regrowth, plays an important role to maintain or restore soil productivity. This is accomplished by the accumulation of nutrients in the biomass and concomitant improvements in physical, chemical and biological characteristics of the soil (Brown and Lugo 1992; Nepstad et al. 1992).

The traditional form of commented smallholder agriculture in Amazon is characterized by slash-and-burn of fallow vegetation (Sollins et al. 1984). Both slashing and burning are severe disturbances to a forest ecosystem (Bauhus et al. 1993) but thought necessary to allow planting of crops, to release organically bound nutrients, to reduce soil acidity, to stimulate the microbial activity and to reduce the weed pressure (Sanchez and Salinas 1982) during the cropping phase of these systems. Slashing and burning invoke nutrient losses by leaching with percolating water, volatilization (principally nitrogen) and Aeolian particle losses (Raison et al. 1985).

The burning of 7-year-old fallow vegetation in the Bragantina region was estimated to cause a loss of $21.5 \mathrm{MgC}(1 \mathrm{Mg}=1 \mathrm{t})$ and $0.37 \mathrm{Mg} \mathrm{N} \mathrm{ha}^{-1}$. Also $45 \%$ to $70 \%$ of the generally less volatile cations potassium, calcium and magnesium were lost, mostly by particle flight in the smoke of the fire. The most disconcerting is the export of about $63 \%$ of the phosphorous stock, which correspond to $11 \mathrm{~kg} \mathrm{ha}^{-1}$ (Sommer 2000).

On the other hand, one of the key problems of sustainable agriculture in the tropics is the fast decomposition of organic matter (Zech et al. 1990) due the elevated temperature, high humidity, and the lack of stabilizing minerals (Sanchez 1976). Inorganic fertilizers are frequently too expensive for the local population to use and their effect is only short-lived due to the low nutrient-holding capacity of the poor soils. 


\subsection{Slash and mulch system}

Soil organic matter (SOM) represents a major proportion of the organic carbon within the terrestrial biosphere and plays an important role in soil fertility (Powlson et al. 2001). An accumulation of organic matter is not only beneficial to soil functions related to agriculture but also represents a sequestration of carbon from atmospheric $\mathrm{CO}_{2}$. In contrast, management practices (e.g. slash and born system in Amazon region) leading to a decline in SOM content release $\mathrm{CO}_{2}$, the major greenhouse gas (Powlson et al. 2001). SOM also has a range of other environmental functions such as water retention and the regulation of trace greenhouse gases between land surface and the atmosphere.

Fallow trees affect the soil by their litter deposition in terms of quantity and quality, root activity and changes in microclimate brought about by the leaf canopy. However, the intensification of land use has drastically reduced the fallow period with a decline in soil productivity and environmental quality and progressive deterioration of natural resources. Therefore, the soil quality has to be restored in shorter time.

Decline in soil productivity and environmental quality and progressive deterioration of natural resources in the tropics have led to a search for new methods to sustain crop production via more efficient nutrient cycling. In Northeastern of Pará (Brazil) the Amazon region was occupied by an intensive colonization process over the last century until today. The region was to be utilized, initially by clearing the forests for timber and later by the use of the land for subsistence agriculture, based on slash and burn activate. In the context of a bilateral German-Brazilian project ("Secondary Forests and Fallow Vegetation in Eastern Amazon Function and Management") slash and mulch system are being recommended to realize firefree land clearing by cutting and chopping the fallow vegetation and leaving mulch layer on site. In addition, the fallow vegetation is enriched with fast-growing legume trees to support the mulching effect by increasing biomass production and nitrogen input during the fallow period.

The purpose of this technique is to maintain soil organic matter and assure a slow and continuous release of nutrients, improve moisture retention, reduces excessive soil heating and runoff, reduce soil erosion, and prevent weed seed germination. Hence, mulching may improve flexibility in planting date to cope with unreliable rain due to conserved soil moisture. 


\subsection{Litter quality manipulation}

The rate of decomposition and the amount of $\mathrm{N}$-mineralization from organic material determines the short-term benefits of tree residues for plant nutrition (Jensen et al. 1995). If burning is to be abandoned, then the synchronization of nutrient release from organic material and nutrient uptake by plants (Addiscott et al. 1991, Myers et al. 1994) accompanying the competition between plant and microorganisms for nutrients (Cattanio unpublished data) will be the core problem in applied tropical soil biology research. Yield losses in field trials of the SHIFT project have shown that yield losses in mulch practices are evident as compared to burned treatments (Kato et al 1999). The same authors showed that yield losses were eliminated with fertilizer application, indicating nutrient competition with decomposers and/or an unfavorable nutrient release pattern as compared to crop demand was a problem.

The structure and decomposability of leaf litter varies to a large degree, thus affecting the rate of nutrient cycling and the nutrient availability in soil (Priha and Smolander 1997). The challenge resides in sustaining crop production while maintaining soil fertility through supply and efficient management of organic residues (Isaac et al. 2000). Biederbeck et al. (1994) suggested that it may be possible to manipulate the timing and quality of litter input through appropriate management of mixed stands to improve the synchrony of nutrient release with crop requirements.

Some works in litter manipulated with mixtures was done by Meentemeyer (1978), Melillo et al. (1982), Anderson et al. (1983), Gallardo and Merino (1993), Vitousek et al. (1994), Hobbie (2000), Lonrez et al (2000), and others. But studies with mixtures in soil litter decomposition were scarce (Franagan and van Cleve 1983). Blair et al. (1990) found in litterbags containing mixed residues that there were significantly greater initial releases of $\mathrm{N}$ and lower subsequent $\mathrm{N}$ immobilization than predicted, and they suggest that it resulted from differences in the decomposer community originated from the mixtures of varied litter resource quality. In the same way, Handayanto et al. (1997), Kuo and Sainju (1998) and Zimmer (2002) showed that soil N-mineralization rate of prunings could be manipulated by mixing different quality materials.

Different organic materials decompose at contrasting rates because they are decomposed differentially by catabolic enzymes produced by saprophytic organisms (Linkins et al. 1984). Furthermore, decomposition rates are affected by nutrient and lignin content of litter (Moorhead et al. 1996), because the initial lignin-to-N and the lignin + polyphenol-to-N ratios 
are correlated well with the $\mathrm{N}$-mineralization or $\mathrm{N}$ accumulation (Constantinides and Fownes 1994a; Janssen 1996; Handayanto et al. 1997).

The decomposition of organic matter is the key process in soil-plant $\mathrm{N}$ cycle (Barraclough 1997) principally governing the availability of this nutrient to crop growth. The chains of processes are very complex, as $\mathrm{NH}_{4}{ }^{+}$, the initial product of $\mathrm{N}$ mineralization, can be consumed by several processes (plant uptake, nitrification, immobilization and volatilization). Heterotrophic bacteria involved in the mineralization-immobilization turnover reactions between inorganic and organic pools of $\mathrm{N}$ compete more effectively for $\mathrm{NH}_{4}{ }^{+}$than for $\mathrm{NO}_{3}{ }^{-}$ (Jansson 1958; Jenkinson et al. 1985; Schimel et al. 1989).

\subsection{Prediction of $\mathbf{N}$ release technique}

Predictions of net N-mineralization are based on C-to-N ratio or N-to-polyphenol ratio in plant residues. However, these predictions are in many cases unreliable because net $\mathrm{N}$ mineralization is affected by $\mathrm{N}$-immobilization and -remineralization or -loss (Stark and Schimel 2001). The technique of ${ }^{15} \mathrm{~N}$ isotope dilution allows gross rates of $\mathrm{N}$-mineralization to be estimated which are unconfounded by the processes that consume $\mathrm{NH}_{4}{ }^{+}$. The isotope dilution approach measures the dilution of a ${ }^{15} \mathrm{~N}$-enriched pool. The measurements are combined with analytical or numerical modeling of the processes involved during residue decomposition (Watkins and Barraclough 1996).

Prediction of N-release is complicated by the simultaneous mineralization of organic residues, and immobilization of inorganic $\mathrm{N}$ by the soil microbial biomass, following residue addition to the soil. This renders the conventional isotope dilution technique (simultaneous addition of residue and fertilizer) invalid for measuring plant $\mathrm{N}$ uptake from organic residues due to the problems associated with pool substitution (Hood et al. 1999). Pool substitution occurs when inorganic ${ }^{15} \mathrm{~N}$ is immobilized and then replaced or substituted by ${ }^{14} \mathrm{~N}$ from native soil $\mathrm{N}$ mineralization (Schimel 1996). This result in a dilution of ${ }^{15} \mathrm{~N}$ that is unrelated to ${ }^{14} \mathrm{~N}$ release from the plant residues and would lead to an overestimated of $\mathrm{N}$ derived from residues (Davidson et al. 1991). When immobilization and mobilization processes of $\mathrm{N}$ in soil are investigated and modeled, it is important to quantify the real amount of $\mathrm{N}$ stored in the soil microbial biomass (Joergensen and Mueller 1996). Transient immobilization of soil $\mathrm{N}$ in the microbial biomass may contribute to improved conservation of soil N sources (Jensen 1997). The errors associated with pool substitution can be overcome by pre-labeling plant material with ${ }^{15} \mathrm{~N}$ before the application of the residue in decomposition experiments. The hypothesis is that when inorganic $\mathrm{N}$ is immobilized on addition of residues, inorganic $\mathrm{N}$ of $\operatorname{similar}{ }^{15} \mathrm{~N}$ 
enrichment replaces it, allowing the isotope dilution technique to be used. This new approach was tested in the laboratory-controlled conditions and showed promising results (Hood et al. 2000).

\subsection{Problems and objectives}

The efficiency with which $\mathrm{N}$ in plant residues is used depends on the rate at which they are mineralized and thus on the time when they are made available relative to crop requirements. The present thesis aims to determine whether, with contrasting legume litter quality in terms of $\mathrm{N}$ mineralization, by mixing this organic material of different quality, it will be possible to alter the pattern of $\mathrm{N}$ release and the efficiency of utilization of $\mathrm{N}$ from the residue by a soil microbial biomass and catch crop.

To this end, four different legume species (Acacia mangium Willd., A. angustissima Kuntze, Sclerolobium paniculatum Vogel and Inga edulis Mart.) each used in enrich the fallow were compared with natural fallow vegetation, which is a mixture of different species, and poor soil without added organic material.

- Within this experiment the following points are essential: a) the impact of enriched legume material in soil $\mathrm{N}$ mineralization; b) the use of mineralization with the use of contrasting litter quality; c) the influence of organic material quality on soil microbial biomass in terms of $\mathrm{N}$ mineralization, immobilization and consumption.

After identifying the contrasting species, two laboratory decomposition experiments with two different techniques will be used to elaborate the effect that mixing these organic materials of different quality has on the pattern of $\mathrm{N}$ release and the efficiency of utilization of $\mathrm{N}$ from the residue by a soil microbial biomass.

The first decomposition experiment was made using soil incorporated legume leaf material from the two contrasting species, and their mixture, with ${ }^{15} \mathrm{~N}$ at natural abundance and fertilized with enriched ${ }^{15} \mathrm{~N}$-urea fertilizer (conventional isotope dilution technique). In parallel, one experiment with the same species and mixture of legume with previously enriched ${ }^{15} \mathrm{~N}$ and fertilized with ${ }^{14} \mathrm{~N}$-urea was carried out (pre-labeling plant material).

- Within this experiment the following points are essential: a) the use of contrasting litter quality may improve N-mineralization in terms of the rate at which they are mineralized; b) the quantification the real amount of $\mathrm{N}$ stored in the soil microbial biomass; $\mathrm{c}$ ) the quantification of N-mineralization and immobilization through the use of labeling techniques. These isotope dilution techniques have the objective to quantify the proportion 
of $\mathrm{N}$ that comes from fertilizer or organic matter and is immobilized by soil microbial biomass.

To assess further whether $\mathrm{N}$ recovery by rice could be accurately predicted from relationships between pruning-material quality and $\mathrm{N}$ mineralization-immobilization, a greenhouse pot experiment was conducted in which the two isotope techniques were used with the same contrasting materials and their mixture, and ${ }^{15} \mathrm{~N}$ uptake by rice was measured.

- Within this experiment the following points are essential: a) whether the use of contrasting litter quality may improve $\mathrm{N}$-mineralization rate and thus the time when they make $\mathrm{N}$ available to the crop; b) the quantification of $\mathrm{N}$ competition between rice and soil microbial biomass; c) the quantification of N-mineralization and immobilization through the use of two techniques of isotope dilution which allow the quantification of the proportion of $\mathrm{N}$ coming from fertilizer or organic matter immobilized by soil microbial biomass and used by rice.

One of the hypothesis of this thesis is that with the elimination of the burning of biomass and the addition of organic matter as mulch, nitrogen immobilization in mulch by microorganisms will be increased and lead to a decrease in the quality of SOM. To confirm this hypothesis a field experiment whit litterbags from different legume treatment was conducted.

- Within this experiment the following points are essential: a) quantifying mulch decomposition during the field incubation on the litter; b) assessing nitrogen and carbon mineralization from mulch system; c) mulch nutrient retention during the field incubation; d) predict of $\mathrm{N}$ mineralization.

In generally this study is intended to answer the following questions:

$\circ \quad$ Can we regulating $\mathrm{N}$ release through the use of mixing residues from legume tree material with different patterns of $\mathrm{N}$ mineralization?

- Is $\mathrm{N}$ immobilization affected by legume tree material and therefore by mixtures?

- Can we fulfill the crop demands with organic matter fertilization (mulching) using materials from enriched fallows?

- What happens with the use of mulch system in terms of N-mineralization and immobilization? 


\section{MATERIAL AND METHODS}

\subsection{Pilot study to determine contrasting legume decomposition}

A laboratory incubation study was conducted on the decomposition rate, varying the fraction of leaf + wood material from selected leguminous trees with contrasting litter quality in comparison of natural fallow, and soil without organic matter amendment. The organic matter was incorporated into the soil. The study lasted 128 days with different sampling time $(0,2,4$, $8,16,32,64$ and 128 days after organic matter incorporated in soil). The objective was to determine net $\mathrm{N}$-mineralization and-immobilization in mixtures of species with contrasting litter quality and the resulting pattern of $\mathrm{N}$ release and efficiency of utilization of $\mathrm{N}$ by soil microorganisms and crop.

\subsubsection{Characterization of plant material}

The plant material separated in leaves and stems used were Acacia mangium Willd., $A$. angustissima Kuntze, Sclerolobium paniculatum Vogel, Inga edulis Mart., and secondary forest regrowth as control. The plant material was collected after 30 months of growth in an enriched fallow ${ }^{1}$ experiment (Brienza 1999).

The material was dried at $80{ }^{\circ} \mathrm{C}$ to constant weight. The separated material from each legume species was analyzed for total C, N, P, lignin, cellulose and polyphenol content.

The plant material was dried in an oven at $80{ }^{\circ} \mathrm{C}$ to constant weight. The dried material was ground and sieved through a $1 \mathrm{~mm}$ mesh. Then, a representative sub-sample was taken and ground finer using a ball mill. The sub-samples were analyzed for total $\mathrm{C}$ and $\mathrm{N}$ with a CarloErba (NA 1500) elementary analyzer.

Approximately $1.0 \mathrm{~g}$ of each plant material was analyzed for lignin and cellulose content by the acid detergent fiber (ADF) method described by van Soest and Wine (1968) and corrected for ash content.

The soluble polyphenolic was determined by the revised Folin-Denis method according to Anderson and Ingram (1989) adapted by Constantinides and Fownes (1994b). The tissue-tosolvent ratio of $1 \mathrm{mg} \mathrm{ml}^{-1}$ was extracted with $50 \%$ methanol at approximately $80{ }^{\circ} \mathrm{C}$ for one hour.

\footnotetext{
${ }^{1}$ Enriched fallow vegetation was made by planting leguminous trees in a natural fallow vegetation. The leguminous trees were planted between the cassava following maize harvest (for more details see Brienza 1999).
} 
Total $\mathrm{P}$ in plant material was determined by an automated colorimetrical method (Technicon AAII, IITA Manual Series $\left.\mathrm{N}^{\circ} 7 ; 1981\right)$. About $0.5 \mathrm{~g}$ of the plant material was digested overnight with a mixture of $500 \mathrm{ml} \mathrm{HClO}_{4}$ and 11 of $\mathrm{HNO}_{3}$. Then, samples were further digested for $2 \mathrm{hrs}$ at $105^{\circ} \mathrm{C}$ and allowed to cool for $10 \mathrm{~min}$. Then $3 \mathrm{ml}$ of $6 \mathrm{~N} \mathrm{HCl}$ was added to each sample, which was digested again for $1-1 / 2$ hours. After being cooled again about 30 $\mathrm{ml}$ of distilled water was added making up the volume to $75 \mathrm{ml}$. Approximately $10 \mathrm{ml}$ of each sample was transferred to the autoanalyzer cups for total phosphorus analyses.

\subsubsection{Experiment procedure}

Sixty grams of air-dried soil (characterized below), $0.824 \mathrm{~g}$ of organic material from legume tree material ( $9 \%$ from leaves, $0.074 \mathrm{~g}$ ), and $0.553 \mathrm{~g}$ of organic material from natural regrowth material (28\% from leaves, $0.155 \mathrm{~g}$ ) was thoroughly mixed. After all samples were prepared $10 \mathrm{ml}$ of deionized water was added to bring the soil moisture content to $40 \%$ of soil water-holding capacity (WHC) in a $250 \mathrm{ml}$ glass Erlenmeyer.

The organic soil amendment corresponded to a concentration of $35.7 \mathrm{t} \mathrm{ha}^{-1}$ of legume organic matter and $24.0 \mathrm{t} \mathrm{ha}^{-1}$ of fallow organic matter from natural regrowth. The selected application rate of organic material was based on data reported by Brienza (1999). All flasks were closed with polyethylene lids and moisture content was controlled regularly by weighing and correcting if losses of more than $1.0 \mathrm{~g}$ water were observed. The flasks were placed randomly in dark control conditions at constant temperature of $26^{\circ} \mathrm{C}$.

The WHC was determined with five disturbed soil samples. The soil samples were soaked with water in a porcelain filter coated with filter paper and covered with aluminum foil to prevent evaporation (Forster 1995). The WHC was calculated with the formula (Equation 1):

$\% \mathrm{WHC}=\left[\left(100-\mathrm{W}_{\mathrm{p}}\right)+\mathrm{W}_{\mathrm{i}}\right] / \mathrm{dwt} \mathrm{X} 100$,

where $W_{p}$ is the weight of the percolated water $(\mathrm{g}), W_{i}$ is the initial amount of water $(\mathrm{g})$ contained in the sample, and $d w t$ is the soil dry weight $(\mathrm{g})$.

\subsubsection{Soil characterization}

In this experiment a low fertility sandy soil from the end of cropping period was employed. The soil was collected in a small farmer in Igarapé-Açu, Brazil (see map below). The texture of this soil showed a high sand content (64\%) and lesser total clay + silt (36\%), with WHC of $24 \%$. 
After being sieved through a $2 \mathrm{~mm}$ net and powdered using a ball mill, the soil held $0.13 \%$ total $\mathrm{N}$ and $1.72 \%$ total C (Carlo Erba NA 1500 analyses), $1.80 \%$ organic C (partial oxidation analysis, Anderson and Imgram 1989), with a $\mathrm{pH}_{\mathrm{H}_{2} \mathrm{O}}$ of 5.60 and $1.34 \mathrm{ppm} \mathrm{P}_{\text {Bray. }}$.

\subsubsection{Measurements}

\subsubsection{Microbial biomass N}

For determination of microbial biomass $\mathrm{N}$ the fumigation-extraction method described by Brookes et al. (1985) was used. The flasks were left in a dark chamber controlled at $26-27{ }^{\circ} \mathrm{C}$ and $70-80 \%$ relative air moisture. After each incubation period the samples were divided in two sets and $25 \mathrm{~g}$ of moist soil was weighed and transferred into $250 \mathrm{ml}$ polyethylene extraction bottles. The first set was extracted immediately with $100 \mathrm{ml}$ of $0.5 \mathrm{M} \mathrm{K}_{2} \mathrm{SO}_{4}$ (shaken for $1 \mathrm{hr}$ at $250 \mathrm{rpm}$ ) and filtered through folded filter paper (5951/2 Schleicher \& Schuell). The extracts were stored frozen until analysis.

The remaining samples in the flask (approximately $25 \mathrm{~g}$ of moist soil) were fumigated with 20 $\mathrm{ml}$ of alcohol-free chloroform $\left(\mathrm{CHCl}_{3}\right)$ in desiccators containing water and $10 \mathrm{ml}$ of $10 \mathrm{M}$ $\mathrm{NaOH}$ and kept in the dark for 24 hours at $26-27^{\circ} \mathrm{C}$. The desiccator was evacuated until the chloroform began to boil. After removal of the $\mathrm{CHCl}_{3}$ with vacuum water pump, the samples were treated as the first set.

Microbial biomass nitrogen $\left(B_{N}\right)$ was calculated with the equation suggested by Jenkinson (1988) that uses the difference between the amount of $\mathrm{N}$ in fumigated and unfumigated soil divided by $k$ constant $(k=0.45)$.

\subsubsection{Mineral nitrogen and total-N}

Inorganic $\mathrm{NH}_{4}{ }^{+}$and $\mathrm{NO}_{3}{ }^{-}$are separately measured by $\mathrm{pH}$ titration after their separation by steam distillation. The $\mathrm{NH}_{4}{ }^{+}-\mathrm{N}$ and $\mathrm{NO}_{3}{ }^{-}-\mathrm{N}$ in the $0.5 \mathrm{M} \mathrm{K}_{2} \mathrm{SO}_{4}$ extracts were determined in $30 \mathrm{ml}$ aliquots by steam distillation during $3 \mathrm{~min}$, using $\mathrm{MgO}$ and posterior Devarda's alloy (Bremner 1965), respectively.

Total-N was determined with $\mathrm{CuSO}_{4}$ solution and conc. $\mathrm{H}_{2} \mathrm{SO}_{4}$ added to the an $0.5 \mathrm{M} \mathrm{K}_{2} \mathrm{SO}_{4}$ extract $(30 \mathrm{ml})$ in a digestion tube, refluxed for $3 \mathrm{~h}$ and steam-distilled with $50 \mathrm{ml} 10 \mathrm{M} \mathrm{NaOH}$ in a vessel containing $5 \mathrm{ml}$ 2\% boric acid (Brookes et al. 1985; Joergensen 1995).

All digested samples were collected into $5 \mathrm{ml}$ of boric acid. After reaching the $30 \mathrm{ml}$ volume, the distillate was titrated with $0.005 \mathrm{M} \mathrm{H}_{2} \mathrm{SO}_{4}$ with an automatic titrator (TR 156, Schott). The 
measurements were made in moist soil and, unless otherwise stated, are means of three replicate determinations. Results are expressed on an oven-dry soils basis $\left(105^{\circ} \mathrm{C}, 24 \mathrm{~h}\right)$. Also, the total-N and -C in soil sub-samples were determined using a $\mathrm{C} / \mathrm{N}$-analyzer (Carlo Erba NA 1500), after powdering the soil with a ball mill and drying at $40{ }^{\circ} \mathrm{C}$ for $2 \mathrm{hr}$.

\subsubsection{3 $\mathrm{CO}_{2}$ production and microbial biomass $\mathrm{C}$}

During the incubation period, the incubation flasks with the same sampling date, after the polyethylene lids was removed and placed with $20 \mathrm{ml}$ of $1 \mathrm{M} \mathrm{NaOH}$ for absorption of $\mathrm{CO}_{2}$ production in 11 closed jars (Alef 1985).

After the end of the incubation period, the $\mathrm{CO}_{2}$ absorbed by $\mathrm{NaOH}$ was precipitated with $1 \mathrm{ml}$ of $1.5 \mathrm{M} \mathrm{BaCl}_{2}$ solution, titrated with $0.1 \mathrm{M} \mathrm{HCl}$ Titrisol using phenolphthalein as an indicator. The sample with an incubation time of more than one week was analyzed for $\mathrm{CO}_{2}$ production each week and $20 \mathrm{ml}$ of $\mathrm{NaOH}$ was replaced in the same jars for continuing the $\mathrm{CO}_{2}$ absorption. The total $\mathrm{CO}_{2}$ production observed in this experiment is the sum of each sampling for the same incubation period.

The microbial biomass $\mathrm{C}$ was determined by dichromate oxidation (Kalembasa and Jenkinson 1973; Vance et al. 1987). Two $\mathrm{ml}$ of $66.7 \mathrm{mM} \mathrm{K}_{2} \mathrm{Cr}_{2} \mathrm{O}_{7}$ and $15 \mathrm{ml}$ of the $\mathrm{H}_{2} \mathrm{SO}_{4} / \mathrm{H}_{3} \mathrm{PO}_{4}$ mixture (2:1) were added to $8 \mathrm{ml}$ of filtered $0.5 \mathrm{M} \mathrm{K}_{2} \mathrm{SO}_{4}$ extract in a $250 \mathrm{ml}$ round-bottomed flask. The mixture was gently refluxed at $40-50{ }^{\circ} \mathrm{C}$ for $30 \mathrm{~min}$, cooled and diluted with $25 \mathrm{ml}$ water, which was added through the condenser as a rinse. The residual dichromate was measured by back titration with $40 \mathrm{mM}$ ferrous ammonium sulphate solution using $25 \mathrm{mM}$ 1.10-phenanthroline-ferrous sulphate as an indicator.

\subsubsection{Statistical analyses}

The general linear model (GLM) procedure was used to perform ANOVA on all soil parameters and significantly different means (at a $95 \%$ confidence level) were separated with the least significant difference (LSD) method for sampling time and Tukey Test for treatment (Wilkinson 1992). 
2.2 Laboratory study with contrasting legume leaf decomposition and gross $\mathrm{N}$ dynamics in soil

\subsubsection{Experimental procedure}

Measuring the $\mathrm{N}$ availability of crop residues to the subsequent crop has been estimated directly by labeling plant with ${ }^{15} \mathrm{~N}$ fertilizer then re-applying the residues to the following crops (Yacob and Blair 1980; Jensen 1994). Prediction of the amount of N plants will take up from organic residues is difficult, as $50 \%$ or more of the total $\mathrm{N}$ is in an organic form and the residue of $\mathrm{N}$ will be dependent on the "quality" of the organic residue (Flowers and Arnold 1993). Prediction of $\mathrm{N}$ release is complicated by the simultaneous mineralization of organic residues and immobilization of inorganic $\mathrm{N}$ by the soil microbial biomass following residue addition to the soil (Hood 2001). The errors associated with pool substitution can be overcome by pre-labeling the residue with ${ }^{15} \mathrm{~N}$.

A study of the decomposition of ${ }^{15} \mathrm{~N}$-labeled plant material from S. paniculatum, I. edulis and the mixture of the two legume species ( $\mathrm{p}^{*} \mathrm{e}$ mixture treatment), with the same amount of $\mathrm{N}$ and contrasting litter quality was conducted to assess rates of gross-mineralization immobilization. The study was conducted under controlled conditions during 64 days in the laboratory. Whereas unlabeled leaf material was used in the pilot experiment (see item 2.1.1), and leaf ${ }^{15} \mathrm{~N}$-labeled material from the same species was collected for the main study from an nine-month-old experiment involving the application of ${ }^{15} \mathrm{~N}$-labelled fertilizer to quantify Biological Nitrogen Fixation (BNF) of a legume-enriched fallow study in the field (Paparcikova et al. 2000).

\subsubsection{Plant-material characterization}

The leaf material from two legume species, S paniculatum and I. edulis, was analyzed for total C, N, P, lignin, cellulose and polyphenol content using the same methods described for the previous experiment (see item 2.1.1).

Sixty grams of air dried soil (characterized below) and a variable amount of leaf material from legume material (Table 1) were thoroughly mixed before $10 \mathrm{ml}$ of deionized water was added to bring the soil moisture content to $40 \%$ of the soil water-holding capacity (WHC) in $250 \mathrm{ml}$ of glass Erlenmeyer (flask). All flasks were closed with polyethylene plastic and moisture content was controlled regularly by weighing and correcting if losses more than $1.0 \mathrm{~g}$ water were observed. The flasks were placed randomly in dark conditions at constant temperature of 
$26^{\circ} \mathrm{C}$. Every day the flasks were moved randomly to compensate for possible differences in temperature.

Table 1. Amount of soil, legume and mixed leaf amended soil, and the total ${ }^{14} \mathrm{~N}$ and ${ }^{15} \mathrm{~N}$ added with leaf material and fertilizer. The numbers represents mean (standard deviation), with $\mathrm{n}=15$.

\begin{tabular}{|c|c|c|c|c|c|}
\hline \multirow{2}{*}{ Treatment } & Soil (g) & Leaf & N-Leaf & $\mathrm{N}$-fertilizer & \multirow{2}{*}{$\begin{array}{c}{ }^{15} \mathrm{~N} \\
\mu \mathrm{g} \mathrm{g}^{-1} \text { soil }\end{array}$} \\
\hline & \multicolumn{2}{|c|}{$\mathrm{g}$} & \multicolumn{2}{|c|}{$\mathrm{mg} \mathrm{g}^{-1}$ soil } & \\
\hline S. paniculatum ${ }^{14 \Phi}$ & $60.56(0.12)$ & $4.43(0.02)$ & $1.64(0.01)$ & $0.06(0.0001)$ & $2.85(0.001)$ \\
\hline $\mathrm{p}^{*} \mathrm{e}^{14}$ mixture & $60.62(0.20)$ & $3.79(0.05)$ & $1.70(0.02)$ & $0.06(0.0001)$ & $2.85(0.001)$ \\
\hline I. edulis ${ }^{14}$ & $60.65(0.13)$ & $2.92(0.01)$ & $1.65(0.01)$ & $0.06(0.0001)$ & $2.85(0.001)$ \\
\hline S. paniculatum ${ }^{15}$ & $60.60(0.15)$ & $4.61(0.03)$ & $1.51(0.01)$ & $0.06(0.0001)$ & $5.93(0.020)$ \\
\hline $\mathrm{p}^{*} \mathrm{e}^{15}$ mixture & $60.61(0.08)$ & $4.53(0.02)$ & $1.52(0.01)$ & $0.06(0.0001)$ & $5.70(0.031)$ \\
\hline I. edulis ${ }^{15}$ & $60.60(0.10)$ & $4.35(0.02)$ & $1.55(0.01)$ & $0.06(0.0001)$ & $6.06(0.021)$ \\
\hline Control & $60.68(0.16)$ & & & $0.06(0.0001)$ & \\
\hline
\end{tabular}

${ }^{\Phi}$ species name with ${ }^{14}$ had leaf with nitrogen in natural abundance and were fertilized with 5.32 atom $\%{ }^{15} \mathrm{~N}$. Species with ${ }^{15}$ had leaf material with enriched ${ }^{15} \mathrm{~N}\left(S\right.$. paniculatum 0.3919 atom $\%{ }^{15} \mathrm{~N}$ and $I$. edulis at 0.3904 atom $\%{ }^{15} \mathrm{~N}$ in leaf material) and were fertilized with fertilizer at natural abundance.

Leguminous species and the mixture of these two species were incorporated in soil with approximately the same amount of $\mathrm{N}$, which resulted in different amounts of leaves dry matter (Table 1). All treatments were fertilized with the same amount of ${ }^{14} \mathrm{~N}$ - or ${ }^{15} \mathrm{~N}$-urea. The leaf material previously enriched with ${ }^{15} \mathrm{~N}$ was fertilized with ${ }^{14} \mathrm{~N}$-urea and conversely, the ${ }^{14} \mathrm{~N}$ leaf material with ${ }^{15} \mathrm{~N}$-urea. The control was soil fertilized with ${ }^{14} \mathrm{~N}$-urea.

\subsubsection{Soil characterization}

In this experiment a low-fertility sandy soil from a field at the end of a fallow period (8 yearsold "capoeira") was employed. The soil had a high sand content (81.3\%) and low total clay $(8 \%)$, and the WHC was $18.4 \%$.

After being sieved through a $2 \mathrm{~mm}$ screen and ground using a ball mill, the soil contained $0.10 \%$ total $\mathrm{N}$ and $1.40 \%$ total C (Carlo Erba NA 1500 analyses), $1.17 \%$ organic C (partial oxidation analysis, Anderson and Ingram 1989), with a $\mathrm{pH}_{\mathrm{H}_{2} \mathrm{O}}$ of 5.40. 


\subsubsection{Measurements and analyses}

\subsubsection{Microbial biomass $\mathbf{N}$}

For determination of microbial biomass $\mathrm{N}$ the previously described method was used (see item 2.1.4).

\subsubsection{Mineral nitrogen analysis}

Total $\mathrm{NH}_{4}{ }^{+}-\mathrm{N}$ and $\mathrm{NO}_{3}{ }^{-}-\mathrm{N}$ in the $2 \mathrm{M} \mathrm{KCl}^{-}$extracts were determined in $30 \mathrm{ml}$ aliquots by steam distillation, using MgO and Devarda's alloy (Bremner 1965), respectively (see item 2.1.4). Hereafter the samples were prepared for isotope ratio by micro-diffusion using a modification of the method by Jensen (1991) and Stark and Hart (1996).

Total-N and $-\mathrm{C}$ in all soil samples were determined using a $\mathrm{C} / \mathrm{N}$-analyzer (Carlo Erba NA 1500), after the drying the soil at $40{ }^{\circ} \mathrm{C}$ for $2 \mathrm{hr}$. The total ${ }^{15} \mathrm{~N}$ soil sample was analyzed in the isotope laboratory (see item 2.1.4).

\subsubsection{Micro-diffusion of $2 \mathrm{M} \mathrm{KCl}$ extracts}

Glass fiber filters ${ }^{2}$ were first washed 5 times with $2 \mathrm{M} \mathrm{KCl}$ and then 5 times with distilled water, with subsequent drying in an oven at $50{ }^{\circ} \mathrm{C}$, and were then quartered. Acid traps were made by cutting $5 \mathrm{~cm}$ wide strips of PTFE $^{3}$ (Teflon) into approximately $4 \mathrm{~cm}$ lengths. Two pieces of the filter were placed approximately $4 \mathrm{~mm}$ apart on one half of the PTFE strip. Ten microlitres of $2.5 \mathrm{M} \mathrm{KHSO}_{4}$ were pipetted onto each piece of filter. The other half of the PTFE strip was folded over to cover the disk-pieces and gently smoothed to remove wrinkles. The open end of a $2.2 \mathrm{~cm}$ diameter plastic centrifuge tube was then gently pressed in a concentric circle around each disk to seal the PTFE. The containers were a $250 \mathrm{ml}$ PVC bottle (extraction bottle), which had a stainless steel hook ( $1 \mathrm{~mm}$ diameter and $4 \mathrm{~cm}$ length) fixed in the lid with heating.

The PTFE acid trap was hooked in the stainless hook at the middle of the one extremity so that the two disks hung at the same height inside the PVC bottle. An aliquot of $50 \mathrm{ml}$ of $2 \mathrm{M}$ $\mathrm{KCl}$ soil extract was added to the extraction bottle with 2 glass beads ( $4 \mathrm{~mm}$ diameter) and 0.2 $\mathrm{g} \mathrm{MgO}$ (heavy power), and the cover with the PTFE acid trap was closed over the extraction bottle.

\footnotetext{
${ }^{2}$ Macherey-Nagel MN GF-4 with diameter of $2.5 \mathrm{~cm}$.

${ }^{3}$ PTFE is polytetrafluoroethylene pipe-sealing tape.
} 
The $\mathrm{MgO}$ facilitates the conversion of $\mathrm{NH}_{4}{ }^{+}$to $\mathrm{NH}_{3}$, which in turn is trapped in the acidified filter disks. The extractions bottles were left for 6 days in an automatic shaking apparatus (125 rpm) at $25-26^{\circ} \mathrm{C}$. After trapping, the two pieces of filter paper were removed from the PTFE trap and placed into $5 \times 12 \mathrm{~mm}$ tin capsules. The tin capsules were placed in titer plates without being sealed, and placed overnight in a desiccator with concentrated $\mathrm{H}_{2} \mathrm{SO}_{4}$ as desiccant, to completely dry the filter disks. The dried samples were closed with pincer, rolled into balls by hand and put into new micro-test plates for isotope ratios analysis at the isotope laboratory of Göttingen University.

$\mathrm{A}^{15} \mathrm{NO}_{3}{ }^{-}$diffusion was conducted in all unfumigated $50 \mathrm{ml}$ of soil $2 \mathrm{M} \mathrm{KCl}$ extract after $\mathrm{NH}_{4}{ }^{+}-\mathrm{N}$ diffusion. After $\mathrm{NH}_{4}{ }^{+}-\mathrm{N}$ diffusion the opened extraction bottle was shaken for 1 day and then $0.4 \mathrm{~g}$ of Devarda's alloy was added. The extraction bottles were again closed with a new PTFE acid trap and the same process described above was conducted for $\mathrm{NO}_{3}{ }^{-}$diffusion. Blank corrections of the $15 \mathrm{~N}$ values were made with diffused and nondiffused standards (Stark and Hart 1996; Corre et al. 2002). The calculation of the mass of $\mathrm{N}$ in the blank was performed with equation (2):

$M_{b}=\left[M_{\text {std }} x\left(E_{m}-E_{s t d}\right)\right] /\left(E_{b}-E_{m}\right)$

where $M_{b ; s t d}$ are mass of $\mathrm{N}$ in the blank and nondiffused Standard, respectively, and $E_{m ; s t d ; b}$ are ${ }^{15} \mathrm{~N}$ in the diffused standard, nondiffused standard and in the blank (assumed to be 0.3663 $\%$, respectively.

Equation 3 was used for correction of the ${ }^{15} \mathrm{~N}$ in the sample based on calculated $\mathrm{N}$ mass in the blank:

$\mathrm{E}_{\mathrm{s}}=\mathrm{E}_{\mathrm{m}}+\left\{\left[\mathrm{M}_{\mathrm{b}} \mathrm{x}\left(\mathrm{E}_{\mathrm{m}}-\mathrm{E}_{\mathrm{b}}\right)\right] / \mathrm{M}_{\mathrm{s}}\right\}$

where $E_{S}$ is corrected ${ }^{15} \mathrm{~N}$ of the sample, and $M_{S}$ is mass of $\mathrm{N}$ in the sample prior to diffusion. Gross mineralization and nitrification rate for the samples that received ${ }^{15} \mathrm{~N}$-urea were estimated using the modified calculation procedure of Davidson et al. (1991) from the Kirkham and Bartholomew (1955) model (Equation 4 and 5). ${ }^{15} \mathrm{~N}$-mineralization and immobilization from enriched ${ }^{15} \mathrm{~N}$-leaf material was calculated with the assumption that the diffused $\mathrm{NH}_{4}{ }^{+}-15 \mathrm{~N}$ and $\mathrm{NO}_{3}{ }_{-}^{-}{ }^{15} \mathrm{~N}$ recovered in nonfumigated soils represent the mineralization rate, and the difference with fumigated soils was presumably due to microbial biomass. This assumption takes into consideration that the microorganisms do not discriminate between ${ }^{14} \mathrm{~N}$ and ${ }^{15} \mathrm{~N}$. Mineralization rate $(m)$ and consumption rate $(c)$ were calculated as follows: 


$$
\begin{aligned}
& \mathrm{m}=\frac{\mathrm{M}_{0}-\mathrm{M}_{\mathrm{t}}}{\mathrm{t}} \times \frac{\log \left(\mathrm{H}_{0} \mathrm{M}_{\mathrm{t}} / \mathrm{H}_{\mathrm{t}} \mathrm{M}_{0}\right)}{\log \left(\mathrm{M}_{0} / \mathrm{M}_{\mathrm{t}}\right)} \\
& \mathrm{c}=\frac{\mathrm{N}_{0}-\mathrm{N}_{\mathrm{t}}}{\mathrm{t}} \times \frac{\log \left(\mathrm{H}_{0} / \mathrm{H}_{\mathrm{t}}\right)}{\log \left(\mathrm{N}_{0} / \mathrm{N}_{\mathrm{t}}\right)}
\end{aligned}
$$

where, $M_{0}$ is initial $\mathrm{NH}_{4}{ }^{+}-\left({ }^{14} \mathrm{~N}+{ }^{15} \mathrm{~N}\right)$ pool (at time 0$), M_{t}$ is post-incubation $\mathrm{NH}_{4}{ }^{+}-\left({ }^{14} \mathrm{~N}+{ }^{15} \mathrm{~N}\right)$ pool (at time $t$ ), $H_{0}$ is initial ${ }^{15} \mathrm{~N}$ pool, $H_{t}$ is post-incubation ${ }^{15} \mathrm{~N}$ pool (at time $t$ ), $N_{0}$ is initial $\mathrm{NO}_{3}{ }^{-}{ }^{14} \mathrm{~N}+{ }^{15} \mathrm{~N}$ pool, $N_{t}$ is post-incubation $\mathrm{NO}_{3}{ }^{-}-\left({ }^{14} \mathrm{~N}+{ }^{15} \mathrm{~N}\right)$ pool (at time $t$ ). Mineralization rate $(m)$ in this work used $\mathrm{NH}_{4}{ }^{+}{ }^{15} \mathrm{~N}$ and consumption rate $(c)$ used $\mathrm{NO}^{-}{ }_{3-}^{-15} \mathrm{~N}$ for the term $H$ in the respective equations.

\subsubsection{Soil-organic C}

The modified Walkley-Black partial oxidation method (Anderson and Ingram 1989) was used to access the organic $\mathrm{C}$ in unfumigated and fumigated soil. About $1 \mathrm{~g}$ ground soil sample was dissolved with $10 \mathrm{ml}$ of $5 \%$ potassium dichromate solution before the $20 \mathrm{ml}$ concentrate $\mathrm{H}_{2} \mathrm{SO}_{4}$ was added with a fast burette. After cooling, $50 \mathrm{ml} 0.4 \%$ barium chloride was added and the resulting solution centrifuged. An aliquot of the clear supernatant solution was transferred into a colorimeter cuvette, and measured absorbance of standard ${ }^{4}$ and sample measured at $600 \mathrm{~nm}$.

\subsection{Greenhouse study with contrasting legume leaf decomposition and gross $\mathrm{N}$ dynamics in soil using rice as an indicator plant.}

\subsubsection{Experimental procedure}

A study of the decomposition of ${ }^{15} \mathrm{~N}$-labeled plant material (S. paniculatum, I. edulis, and $\mathrm{p}^{* \mathrm{e}}$ mixture) with contrasting litter quality was conducted to assess the rates of mineralization and immobilization, using rice as an indicator plant. The study was conducted in a greenhouse during a period of 50 days. The same leaf and soil material from the previous study (see item 2.2.2) was used to find nitrogen derived from ${ }^{15} \mathrm{~N}$ labeled organic matter and ${ }^{15} \mathrm{~N}$ labeled fertilizer using rice as an indicator plant.

\footnotetext{
${ }^{4}$ Standard was sucrose diluted at $0,5,10,15,20$ and $25 \mathrm{ml}$ of $50 \mathrm{mg} \mathrm{C} \mathrm{ml}^{-1}$ solution.
} 


\subsubsection{Measurements and analyses}

\subsubsection{Greenhouse experiment}

The greenhouse experiment was conducted during the summer season and, in a similar way as the previous study (see item 2.2.1), divided in two parts: First, ${ }^{15} \mathrm{~N}$-urea fertilizer $(3.92 \mathrm{mg} \mathrm{N}$ pot $^{-1}$ with 5.34 atom $\%{ }^{15} \mathrm{~N}$ ) and leguminous organic material with $\mathrm{N}$ natural abundance were combined to assess microbial immobilization and abiological $\mathrm{N}$ consumption (Table 2). Second, $\mathrm{N}$-urea fertilizer (3.92 $\mathrm{N} \mathrm{mg} \mathrm{pot}^{-1}$ with $\mathrm{N}$ at natural abundance) and ${ }^{15} \mathrm{~N}$-labeled leguminous organic material from S. paniculatum and I. edulis with $2.02 \% \mathrm{~N}$ and 0.392 atom ${ }^{0}{ }^{15} \mathrm{~N}$, and $1.93 \% \mathrm{~N}$ and 0.390 atom $\%{ }^{15} \mathrm{~N}$, respectively, were used to find the amount of mineral-N coming from organic matter decomposition, and the extent of competition between microorganisms, soil + organic matter fixation, and rice absorption.

Table 2. Amount of organic matter (OM) mixed with soil in a plastic pot and the total ${ }^{14} \mathrm{~N}$ and ${ }^{15} \mathrm{~N}$-excess ${ }^{5}$ added with leaf and fertilizer in greenhouse experiment. The numbers represent mean(standard deviation), $\mathrm{n}=12$.

\begin{tabular}{|c|c|c|c|c|c|}
\hline \multirow{2}{*}{ Treatment } & Soil & Leaf & $\mathrm{N}$ & $\mathrm{N}$-fertilizer & \multirow{2}{*}{$\frac{{ }^{15} \mathrm{~N}}{\mu \mathrm{g} \mathrm{g}^{-1} \text { soil }}$} \\
\hline & \multicolumn{2}{|c|}{ g } & \multicolumn{2}{|c|}{$\mathrm{mg} \mathrm{g}^{-1}$ soil } & \\
\hline S. paniculatum $^{14 \Phi}$ & $50.61(0.07)$ & $70.37(0.002)$ & $1.62(0.001)$ & $0.08(0.002)$ & $3.41(0.002)$ \\
\hline $\mathrm{p}^{*} \mathrm{e}^{14}$ & $50.60(0.13)$ & $70.71(0.000)$ & $1.93(0.001)$ & $0.08(0.002)$ & $3.41(0.001)$ \\
\hline I. edulis ${ }^{14}$ & $50.60(0.10)$ & $64.64(0.003)$ & $2.03(0.001)$ & $0.08(0.002)$ & $3.41(0.002)$ \\
\hline S. paniculatum ${ }^{15}$ & $50.62(0.10)$ & $70.66(0.002)$ & $1.62(0.001)$ & $0.08(0.002)$ & $6.36(0.012)$ \\
\hline $\mathrm{p}^{*} \mathrm{e}^{15}$ & $50.62(0.11)$ & $70.48(0.001)$ & $1.64(0.001)$ & $0.08(0.001)$ & $6.40(0.009)$ \\
\hline I. edulis ${ }^{15}$ & $50.52(0.09)$ & $71.00(0.014)$ & $1.69(0.006)$ & $0.08(0.002)$ & $6.61(0.010)$ \\
\hline Control & $50.68(0.13)$ & & & $0.08(0.001)$ & \\
\hline
\end{tabular}

${ }^{\Phi}$ species name with ${ }^{14}$ had leaf with nitrogen at natural abundance and was fertilized with 5.34 atom $\%$ ${ }^{15} \mathrm{~N}$. Species name with ${ }^{15}$ had leaf with enriched ${ }^{15} \mathrm{~N}$ (both species at $0.39 \%{ }^{15} \mathrm{~N}$ in leaf material) and was fertilized with fertilizer at natural abundance.

The legumes and their mixture were incorporated in the soil with approximately the same amount of $\mathrm{N}$, which resulted in different amounts of organic matter. Control was the soil with native organic matter and fertilized with $\mathrm{N}$-urea $\left(3.92 \mathrm{mg} \mathrm{N}^{-1}\right.$ with $\mathrm{N}$ at natural abundance).

\footnotetext{
${ }^{5}{ }^{15} \mathrm{~N}$ is expressed as the atom $\%{ }^{15} \mathrm{~N}$ excess abundance above the background $(0.3663$ atom $\%)$
} 
The plastic pots were placed in the greenhouse. In each pot, after 6 days of watering the soil with distilled water to $50 \%$ of field capacity (pre-incubation time), two rice seedlings (Oryza sativa L., JR50) were planted and after that the pots were fertilized. Two weeks before beginning the experiment the seedlings were germinated in a plastic tray with the same soil used in the experiment (without fertilization). Twice per day the plots were irrigated with deionized water. Some minutes after irrigation, the water that was drained was again placed in the pot.

\subsubsection{Microbial biomass $N$}

For determination of microbial biomass $\mathrm{N}$, the above-described method was used (see item 2.2.4). The difference was that only the first approximately $4 \mathrm{~cm}$ of soil in each pot was used for extraction with $2 \mathrm{M} \mathrm{KCl}$. The sampling soil took place after harvesting the two rice plants for analysis.

\subsubsection{Mineral nitrogen analysis}

For determination of mineral $\mathrm{N}$ the method described in item 2.2.4 was used.

\subsubsection{Micro-diffusion of $2 \mathrm{M} \mathrm{KCl}$ extracts}

For determination of mineral $\mathrm{N}$ the method described in item 2.2.4 was used.

\subsubsection{5 ${ }^{15} \mathrm{~N}$ in soil and plant sample}

After drying, the soil and rice plant material was ground separately using a ball mill. The finely ground material was again dried for at least 12 hours at $60^{\circ} \mathrm{C}$ before weighing. Between 40 and $80 \mathrm{mg}$ of the soil sample and 3 and $6 \mathrm{mg}$ of the plant sample were weighed into a tin capsules for isotopic measurement. After each ten unknown samples, two acetanilide as standards (between 0.4 and $1.5 \mathrm{mg}$ ) were measured for controlling purposes. All ${ }^{15} \mathrm{~N}$ analyses were conducted in the isotope laboratory of the University of Göttingen. The nitrogen-content was determined after combustion of the ${ }^{15} \mathrm{~N}$ in Mass Spectrometer, Finningan, MAT 251 (Reineking et al. 1993).

The ${ }^{15} \mathrm{~N}$-analyses of the soil and of the plant material indicated the percentage of $\mathrm{N}$ in the sample. The dry matter previously determined, allowed the calculation of total- $\mathrm{N}$ in the samples (Panda et al. 1995). 


\subsubsection{6 $\mathrm{N}$ derived from ${ }^{15} \mathrm{~N}$-fertilizer (NdfF)}

Nitrogen derived from fertilizer (\% and $\mathrm{mg}$ ) in the plant was calculated according to Panda et al. (1995) with the following equations (Equation 6 and 7):

$$
\begin{aligned}
& \operatorname{NdfF}(\%)=\left(\frac{\% \text { Atom }{ }^{15} \mathrm{~N} \text { of the sample }-0.3663}{\% \text { Atom }{ }^{15} \mathrm{~N} \text { of the fertilizer }-0.3663}\right) \times 100 \\
& \operatorname{NdfF}(\mathrm{mg})=\frac{\mathrm{NdfF}(\%) \times \text { Total } \mathrm{N}(\mathrm{mg})}{100}
\end{aligned}
$$

\subsubsection{Urea-N-recovery}

Urea-N-recovery was calculated as the percentage of the urea taken up by the rice plants $(\mathrm{N}$ recovery by rice, $\mathrm{NrR})$. The total recovery within the system $(\mathrm{NrS})$ represents the share of urea- $\mathrm{N}$ found in the rice-soil system. The following equations were used (Equation 8 and 9):

$$
\begin{aligned}
& \operatorname{NrR}(\%)=\left(\frac{\operatorname{NdfF}(\mathrm{mg}) \text { in the (shoots }+ \text { roots })}{\text { Fertilizer amount }(\mathrm{mg})}\right) \times 100 \\
& \operatorname{NrS}(\%)=\left(\frac{\mathrm{NdfF}(\mathrm{mg}) \text { in the rice and soil }}{\text { Fertilizer amount }(\mathrm{mg})}\right) \times 100
\end{aligned}
$$

\subsubsection{N derived from soil (NdfS)}

The share in nitrogen derived from soil can be calculated from the sample without added leaf material as in following equation (Equation 10):

$\mathrm{NdfS}=$ Total-N (mg) $-\mathrm{NdfF}(\mathrm{mg})$

\subsubsection{9 $\mathrm{N}$ derived from residue (Ndfr)}

Using the direct method, the percentage $\mathrm{N}$ derived from residue ${ }^{6}(\% \mathrm{Ndfr})$ was calculated using Equation $11(\operatorname{Hood} 2001)$ :

\footnotetext{
${ }^{6}$ The residue means added leaf material.
} 


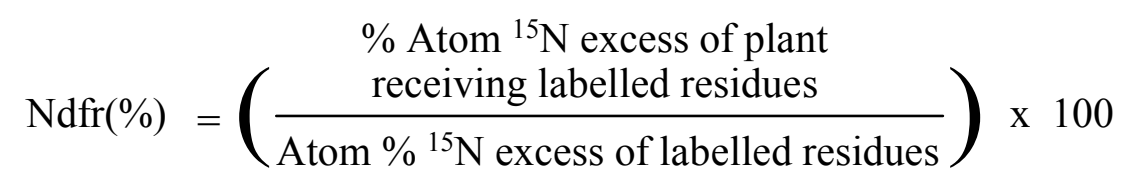

\subsubsection{0 $\mathrm{N}$ recovered from residue $(\mathrm{Nrfr})$}

The amount of $\mathrm{N}$, which was recovered from residue (Nrfr), was calculated using the Equations 12, where $\mathrm{Ndfr}(\mathrm{mg})$ mean the amount of $\mathrm{N}$ derived from residue calculated with the Equation $13(\operatorname{Hood} 2001)$ :

$$
\begin{aligned}
& \operatorname{Nrfr}(\%)=\frac{\operatorname{Ndfr}(\mathrm{mg})}{\mathrm{N} \text { added as residue }(\mathrm{mg})} \quad \mathrm{N} 100 \\
& \operatorname{Ndfr}(\mathrm{mg})=\frac{\operatorname{Ndfr}(\%) \times \text { Total N }(\mathrm{mg})}{100}
\end{aligned}
$$

\subsubsection{Statistical analysis}

The difference between the individual treatments was tested for their statistical significance at a 95\% confidence level. The significance of the effect of individual legume species, legume mixture and urea fertilizer were verified using a two-factorial analysis with SYSTAT program (Wilkinson 1992).

\subsection{Field experiment}

\subsubsection{Location}

The field experiment area was near Igarapé-Açú (Figure 1), Northeast of Pará State, in the Amazon region of Brazil, located at $1^{\circ} 11^{\prime} \mathrm{S}$ and $47^{\circ} 34^{\prime} \mathrm{W}$. This region was largely deforested a century ago and is now dominated by subsistence food-crop production of small holders using the shifting cultivation system. 


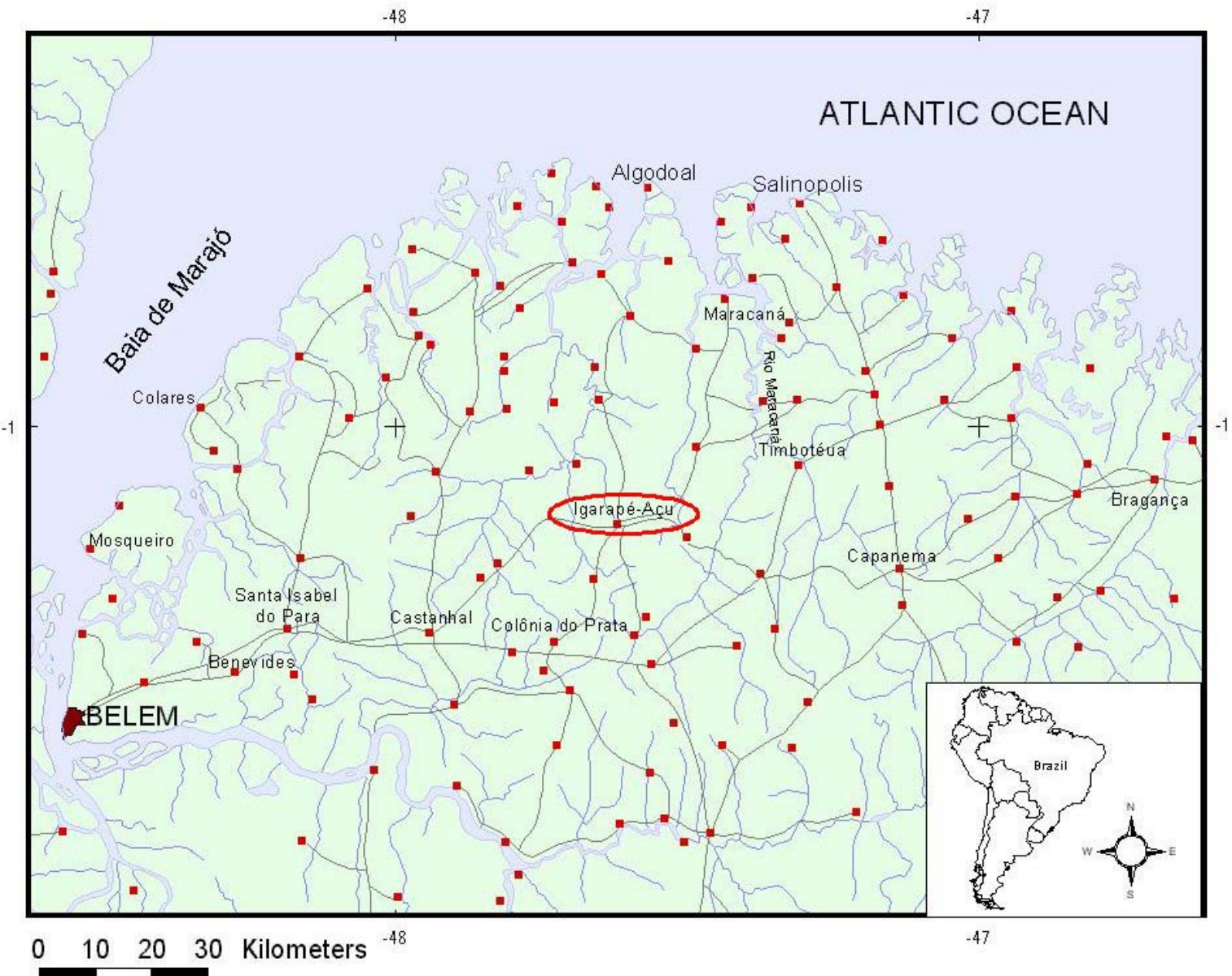

Figure 1. Map of the northeast of Pará State, Brazil, with Igarapé-Açú region in highlight.

\subsubsection{Soil}

The strongly weathered soils of the region are derived from material deposited during the Pleistocene and Pliocene. Rego et al. (1993) classified the dominating soils as typical Kandiudults (USDA Soil Taxonomy), with the following surface-soil $(0-20 \mathrm{~cm})$ properties: $1.6 \%$ total $\mathrm{C}, 0.13 \%$ total $\mathrm{N}, 1.3$ ppm total $\mathrm{P}, \mathrm{pH}_{\left(\mathrm{H}_{2} \mathrm{O}\right)}$ of 5.5 , sandy texture $(82 \%$ sand, $18 \%$ clay + silt) and a bulk density of $1.3 \mathrm{~g} \mathrm{~cm}^{-3}$.

\subsubsection{Climate}

Total rainfall ranges from 2000 to $3000 \mathrm{~mm}_{\text {year }}{ }^{-1}$ with three months of low rainfall (September-November). The mean annual temperature is about $25-27^{\circ} \mathrm{C}$, and relative humidity at about 80-90\%. Monthly variations in the mean temperature range between 25.5 ${ }^{\circ} \mathrm{C}$ and $26.8{ }^{\circ} \mathrm{C}$ and the relative humidity is between $80 \%$ and $89 \%$. 


\subsubsection{Study description}

The study was conducted during one year after slashing and mulching the standing aboveground biomass in an experiment on the dynamics of enriched fallow vegetation with leguminous trees such as Acacia mangium Willd (total aboveground biomass $=55.6 \mathrm{Mg} \mathrm{ha}^{-1}$ ), A. angustissima Kuntze (33.5 $\mathrm{Mg} \mathrm{ha}^{-1}$ ), Sclerolobium paniculatum Vogel (32.2 $\mathrm{Mg} \mathrm{ha}^{-1}$ ), Inga edulis Mart. (30.0 $\mathrm{Mg} \mathrm{ha}^{-1}$ ), and Clitoria racemosa G. Don (27.2 $\left.\mathrm{Mg} \mathrm{ha}^{-1}\right)$, and secondary forest regrowth (24.0 Mg ha ${ }^{-1}$ ) as control (Brienza 1999). After 30 months of growth, trees were slashed and chopped to produce mulch. Following chopping, samples of bulked fresh material from the five leguminous species with, presumably, contrasting litter quality characteristics, and one mixture of species from the control were collected.

Decomposition and $\mathrm{N}$ and $\mathrm{C}$ release were studied using fine-mesh litter bags $(11 \mathrm{~cm} \mathrm{x} 9 \mathrm{~cm}$, mesh-size $<0.2 \mathrm{~cm}$ ). About $25 \mathrm{~g}$ of ground dry material, equivalent to $25 \mathrm{Mg} \mathrm{ha}^{-1}$ based upon the surface area of the bag and standing aboveground biomass of the control as reported by Brienza (1999), were enclosed per bag.

Nine litterbags per treatment for each sampling were placed randomly on three of the $10 \mathrm{~m} \mathrm{x}$ $8 \mathrm{~m}$ plots, with the corresponding species before slashing the trees. When the maize was planted the litterbags were placed below the thick layer of chopped material. For testing this cover effect, three litter bags per sample date were placed outside the plot on bare soil. At 0 , $6,12,24,48$, and 96 days after the beginning of the experiment, the litterbags were removed, brushed free of foreign material, including roots, and the residues were dried in an electric oven at $80{ }^{\circ} \mathrm{C}$ until constant weight.

\subsubsection{Chemical analysis}

The content of dry matter and nutrients analyzed was corrected for ash content (Isaac et al. 2000) using the following formula (Equation 14). Soil contamination was accounted for by ashing an approximately $1 \mathrm{~g}$ subsample in a muffle furnace at $500{ }^{\circ} \mathrm{C}$ for $3 \mathrm{~h}$ and converting the data to an ash-free basis. The ash-free dry weight (g) was calculated using the following formula:

$$
\text { Dry weight }-\left(\frac{\text { Increase in total residual ash }}{\text { Ash content of initial material }}\right)
$$




\subsubsection{Total carbon and nitrogen}

The litter bags material was dried in an oven at $80{ }^{\circ} \mathrm{C}$ to constant weight. The dried material was ground and sieved through a $1 \mathrm{~mm}$ mesh. Then, a representative sub-sample was taken and ground using a ball mill. The sub-samples were analyzed for total $\mathrm{C}$ and $\mathrm{N}$ with a CarloErba (NA 1500) elemental analyzer.

\subsubsection{Lignin and cellulose}

Approximately $0.5 \mathrm{~g}$ of each litter bag material was analyzed for lignin and cellulose content by the ADF method (van Soest and Wine 1968) and corrected for ash content.

\subsubsection{Soluble polyphenol}

The soluble polyphenolic was determined by the revised Folin-Denis method according to Anderson and Ingram (1989) und adapted by Constantinides and Fownes (1994b) (see item 2.1.1).

\subsubsection{Total phosphorus in plant material}

Total $\mathrm{P}$ in plant material from each litterbag was determined by an automated colorimetrical method (Technicon AAII, IITA Manual Series $N^{\circ} 7$; 1981) above described (see item 2.1.1).

\subsubsection{Statistical analysis}

Ash-free dry weight of remaining plant material and the decomposition rate constants (see below) were analyzed using one-way analysis of variance and Pearson's correlation coefficient, to determine differences in decomposition and nutrient release patterns among six treatments as affected by their chemical composition.

The single (Equation 15) and double (Equation 16) exponential equation were used to calculate the decomposition rate constants (Olson 1963; Wieder and Lang 1982), where $A_{t}$ is the proportion of material remaining at time $t ; S$ is the initial proportion of labile material; (1$S$ ) is the initial proportion of resistant material; $k$ is the rate constant for the labile component; and $h$ is the rate constant for the resistant component.

$$
\begin{aligned}
& A_{t}=e^{-k * t} \\
& A_{t}=S * e^{-k * t}+(1-S) * e^{-h * t}
\end{aligned}
$$


The proportion was used to obtain mathematical descriptions of the data that characterize the observed changes over time and compare different treatments. The assumption underlying the single exponential model can be expressed in two ways (Wieder and Lang 1982): either the absolute decomposition rate decreases linearly as the amount of substrate remaining declines, or the relative decomposition remains constant. The proportion of $S$ to $(1-S)$ is a characteristic attributed to initial, undecomposed litter. The double exponential model does not consider any possible transfer of labile to recalcitrant material, as may occur in the synthesis of microbial biomass during decomposition. All statistical analyses were performed using the SYSTAT program (Wilkinson 1992).

\section{RESULTS AND DISCUSSION}

\subsection{Pilot study to identify contrasting leguminous decomposition on leaf and wood material incorporated in the soil}

\subsubsection{Biochemical characteristics of the plant materials}

The materials used in the study spanned a range with regard to the quality characteristics measured (Table 3). Leaf material had larger $\mathrm{N}$ and $\mathrm{P}$ contents than wood materials, which had a higher concentration of cellulose. The concentration of lignin was higher in leaves than wood for some species because the material was collected from a 30 months legume trees and some species, like A. mangium and I. edulis, possess hard leaves with a high lignin concentration (Constantinides and Fownes 1994a). 
Table 3. Nutrient content (\% dry weight) in leaf and wood of the different legume species used in laboratory decomposition experiment.

\begin{tabular}{l|cccccccccc}
\hline Leaf material & $\mathrm{N}$ & $\mathrm{C}$ & $\mathrm{P}$ & $\mathrm{Ca}$ & $\mathrm{Mg}$ & $\mathrm{K}$ & $\mathrm{Na}$ & Lignin Cellulose Phenolics \\
\hline A. angustissima & 5.0 & 52.4 & 0.26 & 0.66 & 0.31 & 1.6 & 0.20 & 19.1 & 14.8 & 14.9 \\
A. mangium & 2.6 & 53.7 & 0.08 & 1.15 & 0.35 & 0.8 & 0.70 & 30.0 & 16.6 & 10.9 \\
C. racemosa & 2.8 & 49.5 & 0.19 & 0.74 & 0.30 & 1.4 & 0.05 & 25.2 & 22.7 & 4.2 \\
Fallow vegetation & 1.5 & 43.2 & 0.08 & 0.48 & 0.14 & 0.3 & 0.08 & 33.5 & 22.2 & 8.2 \\
I. edulis & 3.5 & 50.6 & 0.19 & 1.15 & 0.30 & 1.6 & 0.02 & 33.5 & 32.7 & 8.0 \\
S. paniculatum & 2.4 & 54.6 & 0.09 & 0.46 & 0.19 & 0.7 & 0.12 & 36.2 & 17.6 & 8.4 \\
\hline Woody material & $\mathrm{N}$ & $\mathrm{C}$ & $\mathrm{P}$ & $\mathrm{Ca}$ & $\mathrm{Mg}$ & $\mathrm{K}$ & $\mathrm{Na}$ & $\mathrm{Lignin}$ & $\mathrm{Cellulose}$ & Phenolics \\
\hline A. angustissima & 0.8 & 50.3 & 0.03 & 0.60 & 0.08 & 0.3 & 0.08 & 21.3 & 40.0 & 11.3 \\
A. mangium & 0.6 & 48.8 & 0.02 & 1.20 & 0.07 & 0.2 & 0.1 & 16.9 & 45.5 & 10.6 \\
C. racemosa & 1.1 & 48.3 & 0.04 & 0.98 & 0.11 & 0.3 & 0.02 & 43.1 & 26.8 & 1.4 \\
Fallow vegetation & 0.6 & 43.3 & 0.03 & 0.57 & 0.18 & 0.4 & 0.03 & 22.9 & 44.1 & 12.5 \\
I. edulis & 0.9 & 49.6 & 0.04 & 0.91 & 0.17 & 0.3 & 0.03 & 24.4 & 39.2 & 3.1 \\
S. paniculatum & 0.6 & 49.6 & 0.02 & 0.61 & 0.06 & 0.2 & 0.06 & 20.4 & 27.4 & 5.4 \\
\hline
\end{tabular}

Phenol and cellulose content was different between leaf and wood material. The phenol concentration is higher in leaf material, and only the wood material of the fallow vegetation showed a high phenol concentration.

The nutrient content in the organic amendment (wood + leaf material) for different treatments and soils is shown in Table 4. I. edulis and A. mangium had a higher $\mathrm{N}$ content initially than the other single-legume treatments. But the leaf + wood material added to soil from $S$. paniculatum and A. mangium showed an initially higher $\mathrm{P}$ concentration. For these two important chemical elements, the mixture of two legumes showed an intermediate concentration in comparison to the single species. 
Table 4. Initial organic matter added to soil and the nutrient (selected) content and material quality for different treatments in a laboratory incubation experiment. The number represents Mean (standard deviation), with $\mathrm{n}=21$.

\begin{tabular}{|c|c|c|c|c|c|c|c|}
\hline \multirow{2}{*}{ Species } & $\mathrm{OM}$ & $\mathrm{N}$ & $\mathrm{C}$ & $\mathrm{P}$ & Lignin & Cellulose & Phenol \\
\hline & \multicolumn{7}{|c|}{$\mathrm{mg} \mathrm{g}^{-1}$ soil } \\
\hline A. mangium & $14.15(0.14)$ & $0.11(0.001)$ & $6.84(0.07)$ & 0.004 & $2.61(0.03)$ & $5.95(0.06)$ & $1.50(0.02)$ \\
\hline$m^{*} e^{z}$ & $14.33(0.14)$ & $0.14(0.003)$ & $6.90(0.07)$ & 0.007 & $3.16(0.04)$ & $5.76(0.05)$ & $1.03(0.01)$ \\
\hline I. edulis & $14.11(0.04)$ & $0.17(0.001)$ & $6.77(0.02)$ & 0.009 & $3.59(0.01)$ & $5.42(0.01)$ & $0.52(0.00)$ \\
\hline S. paniculatum & $14.16(0.11)$ & $0.11(0.001)$ & $6.83(0.05)$ & 0.004 & $3.15(0.03)$ & $3.72(0.03)$ & $\mathbf{0 . 8 2}(0.01)$ \\
\hline $\mathrm{p}^{*} \mathrm{a}^{\S}$ & $14.30(0.14)$ & $0.15(0.002)$ & $6.97(0.07)$ & 0.007 & $3.10(0.03)$ & $4.53(0.04)$ & $1.26(0.01)$ \\
\hline A. angustissima & $14.26(0.22)$ & $0.18(0.005)$ & $7.01(0.11)$ & 0.008 & $3.00(0.05)$ & $5.27(0.08)$ & $1.67(0.03)$ \\
\hline Fallow & $9.50(0.06)$ & $0.08(0.001)$ & $4.68(0.03)$ & 0.004 & $2.51(0.02)$ & $3.91(0.03)$ & $1.05(0.01)$ \\
\hline Soil & & 1.27 & 16.73 & 0.001 & & & \\
\hline
\end{tabular}

${ }^{¥}$ In this study, $\mathrm{m} *$ e represents a mixture of A. mangium and I. edulis $(50: 50 \mathrm{w} / \mathrm{w})$.

${ }^{\S}$ In this study, $\mathrm{p}^{*}$ a represents a mixture of $S$. paniculatum and A. angustissima $(50: 50 \mathrm{w} / \mathrm{w})$.

\subsubsection{Total $\mathrm{N}$ in the soil}

Total nitrogen content in the soils during the incubation time is exhibited in Table 5. The preincubation was done for soil moisture homogenization, because the soil was in dry storage for a long time. All treatments showed a decrease in total-N content in the soil at the end of the soil incubation period. After 128 days of incubation the significant difference between legume species and mixture were found only for the $S$. paniculatum treatment, which showed the lowest total-N concentration. This same species showed a higher initial C-to-N ratio and lignin concentration. In this way, legume species and fallow treatment had a significant positive correlation $\left(\mathrm{r}^{2}=0.59, \mathrm{P}<0.01\right)$ with the total-N losses and initial C-to-N ratio. The total-N losses ${ }^{7}$ decrease in the following order: $S$. paniculatum $>$ Fallow vegetation $>A$. mangium $=$ A. angustissima $>$ soil $>I$. edulis ${ }^{8}$. Due to the use of closed-bottom flasks the nitrogen losses can be explained only through the denitrification or volatilization process.

\footnotetext{
${ }^{7}$ Losses mean the differences of total $\mathrm{N}$ concentration in soil between begin and end of incubation period. 8 " $>$ " symbol represents statistical differences at $\mathrm{P}<0.05$, and " $=$ " no statistical difference.
} 
Table 5. Total $\mathrm{N}$ content ( $\mathrm{g} \mathrm{N} \mathrm{kg}^{-1}$ soil) for different legume species and mixtures in comparison to fallow and soil without added organic matter during the laboratory decomposition time.

\begin{tabular}{lcccccccc}
\hline \multirow{2}{*}{ Treatment } & \multicolumn{7}{c}{ Incubation period (days) } \\
\cline { 2 - 8 } & $-6^{\Phi}$ & 0 & 2 & 4 & 8 & 16 & 64 & 128 \\
\hline A. mangium & 1.16 & 1.11 & 1.00 & 0.91 & 1.28 & 1.10 & 1.04 & 0.81 \\
$\mathrm{~m}^{*} \mathrm{e}$ & 1.12 & 1.18 & 1.23 & 1.20 & 0.90 & 1.05 & 0.91 & 0.91 \\
I. edulis & 1.18 & 1.13 & 1.09 & 1.09 & 0.98 & 1.00 & 0.98 & 0.95 \\
S. paniculatum & 1.25 & 1.40 & 1.32 & 1.04 & 0.93 & 0.91 & 0.86 & $0.59^{*}$ \\
p*a & 1.10 & 1.04 & 1.05 & 1.15 & 1.02 & 0.97 & 0.85 & 0.93 \\
A. angustissima & 1.11 & 1.12 & 1.30 & 1.06 & 0.96 & 1.42 & 1.01 & 0.77 \\
Fallow & 1.12 & 1.10 & 1.09 & 1.10 & 0.81 & 1.20 & 1.00 & $0.61^{*}$ \\
Soil & 1.04 & 1.04 & 1.03 & 0.98 & 0.72 & 0.86 & 0.80 & 0.60 \\
\cline { 2 - 9 }$\quad$ LSD $_{(\leq 0.05)}$ & 0.065 & 0.045 & 0.096 & 0.110 & 0.031 & 0.157 & 0.031 & 0.039 \\
\hline
\end{tabular}

${ }^{\Phi}$ Pre-incubation period.

Least significant difference (LSD) compare treatments within the same sampling time.

*Due to problem in the analyses this value represents the average between two repetitions.

The mixture of $S$. paniculatum and $A$. angustissima showed a significant inhibitory effect in the total remaining nitrogen. Only $10.8 \%$ of total-N was lost which was thus considerably lower $(\mathrm{P}<0.01)$ than the losses from the single species (Table 5$)$. However, the other mixture did not exhibit statistical differences in relation to the single species.

\subsubsection{Total nitrogen mineral $\left(\mathrm{NH}_{4}{ }^{+}+\mathrm{NO}_{3}{ }^{-}\right)$in the soil}

Soil-nitrogen mineralization without added organic matter more than doubled the amount of mineral $\mathrm{N}$ in the soil (Figure 2). This control treatment showed a rapid initial increase after it became steadier. In contrast, the amended soils showed immobilization-consumption of the native soil- $\mathrm{N}$, reversing into a release of $\mathrm{N}$ after about a month for the legume-amended soil, particularly if $\mathrm{m}^{*} \mathrm{e}$ mixture or $S$ paniculatum were present. The fallow amended soil was slower in immobilizing soil-N, but continued to immobilize over the entire incubation period. 


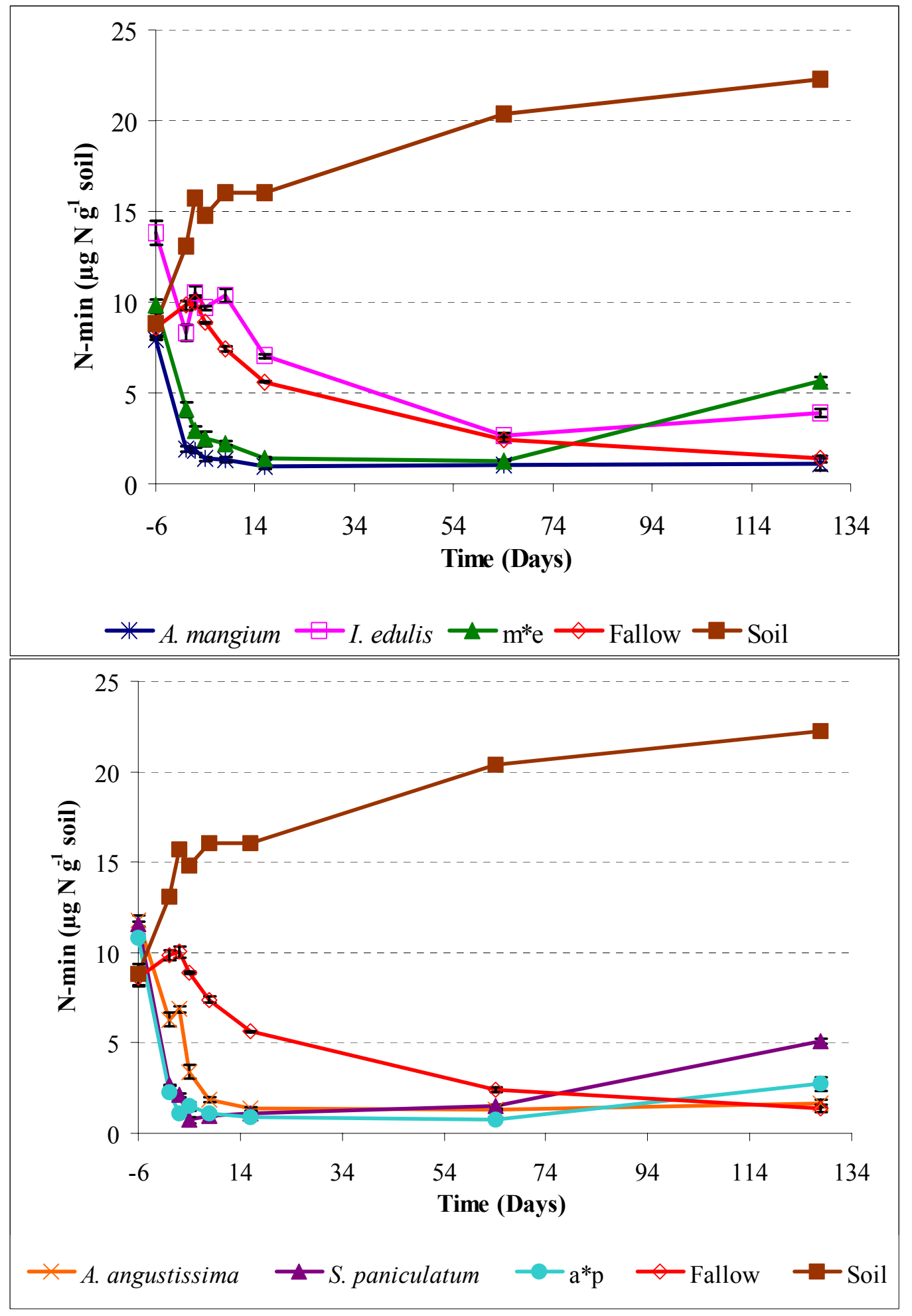

Figure 2. Soil inorganic $\mathrm{N}$ concentration as affected by incorporated wood and leaves from different legumes species in comparison with fallow vegetation (Fallow) and soil with initial organic matter. In all graphics the $\mathrm{m}^{*} \mathrm{e}$ and $\mathrm{p}^{*}$ a symbol correspond to $A$. mangium and $I$. edulis mixture (50:50 w/w), and A. angustissima and $S$. paniculatum mixture (50:50 w/w), respectively. Bars represent standard error of the mean. 
Total mineral nitrogen in leguminous-amended soil was significantly different with time $(\mathrm{P}<$ $0.01)$ for the two species used in the mixtures, and for the interaction species and time ( $\mathrm{P}<$ 0.01). The higher differences were found in the beginning of the incubation period and the final inorganic $\mathrm{N}$ content in legume-amended soil ranged from 2.0 to $6.1 \mathrm{mg} \mathrm{N} \mathrm{kg}^{-1}$ soil compared with $1.6 \mathrm{mg} \mathrm{N} \mathrm{kg}^{-1}$ soil in the fallow-amended soil and $20.7 \mathrm{mg} \mathrm{N} \mathrm{kg}^{-1}$ soil in the control soil. Thus, at the end of incubation period, mineral nitrogen decreased in the following order: Soil as control $>$ S. paniculatum $>$ I. edulis $>$ A. mangium $>$ A. angustissima $>$ natural fallow ${ }^{9}$.

The decomposition patterns of the mixture and total $\mathrm{N}$-mineralization did not reflect the simple mean of the decomposition patterns of single-species organic matter. The $\mathrm{m}^{*} \mathrm{e}^{10}$ mixture showed a higher increase in total $\mathrm{N}$ mineral at the end of the experiment, and that of the single species was comparatively lower in the same period. In the same way a*p mixture did not amount to the arithmetic mean of the N-mineralization in of the two single species

\subsubsection{Nitrogen mineralization and immobilization}

Initial N-mineralization was found in control, I. edulis and fallow treatment (Figure 3). However, after 64 days of soil incubation $S$. paniculatum, the $\mathrm{m}^{*} \mathrm{e}$ mixture and $\mathrm{p}^{*}$ a mixture showed a higher increase in soil organic $\mathrm{N}$ mineralization. Initial nitrification was significantly higher for soil without added organic matter, I. edulis and Fallow treatment. The I. edulis treatment presented a significantly higher consumption of $\mathrm{NO}_{3}{ }^{-}-\mathrm{N}$ after approximately 4 days of incubation (Figure 3 ). Only $I$. edulis and the $\mathrm{m}^{*} \mathrm{e}$ mixture showed a small increase in $\mathrm{NO}_{3}{ }^{-}-\mathrm{N}$ concentration at the end of the experiment; the other treatments showed $\mathrm{NO}_{3}{ }^{-}-\mathrm{N}$ consumption and/or denitrification.

\footnotetext{
${ }^{9}$ The ">" symbol represents statistical differences at $\mathrm{P}<0.05$.

${ }^{10}$ In text the $\mathrm{m}^{*} \mathrm{e}$ and $\mathrm{p}^{*} \mathrm{a}$ symbol correspond to A. mangium and I. edulis mixture, and A. angustissima and $S$. paniculatum mixture, respectively.
} 


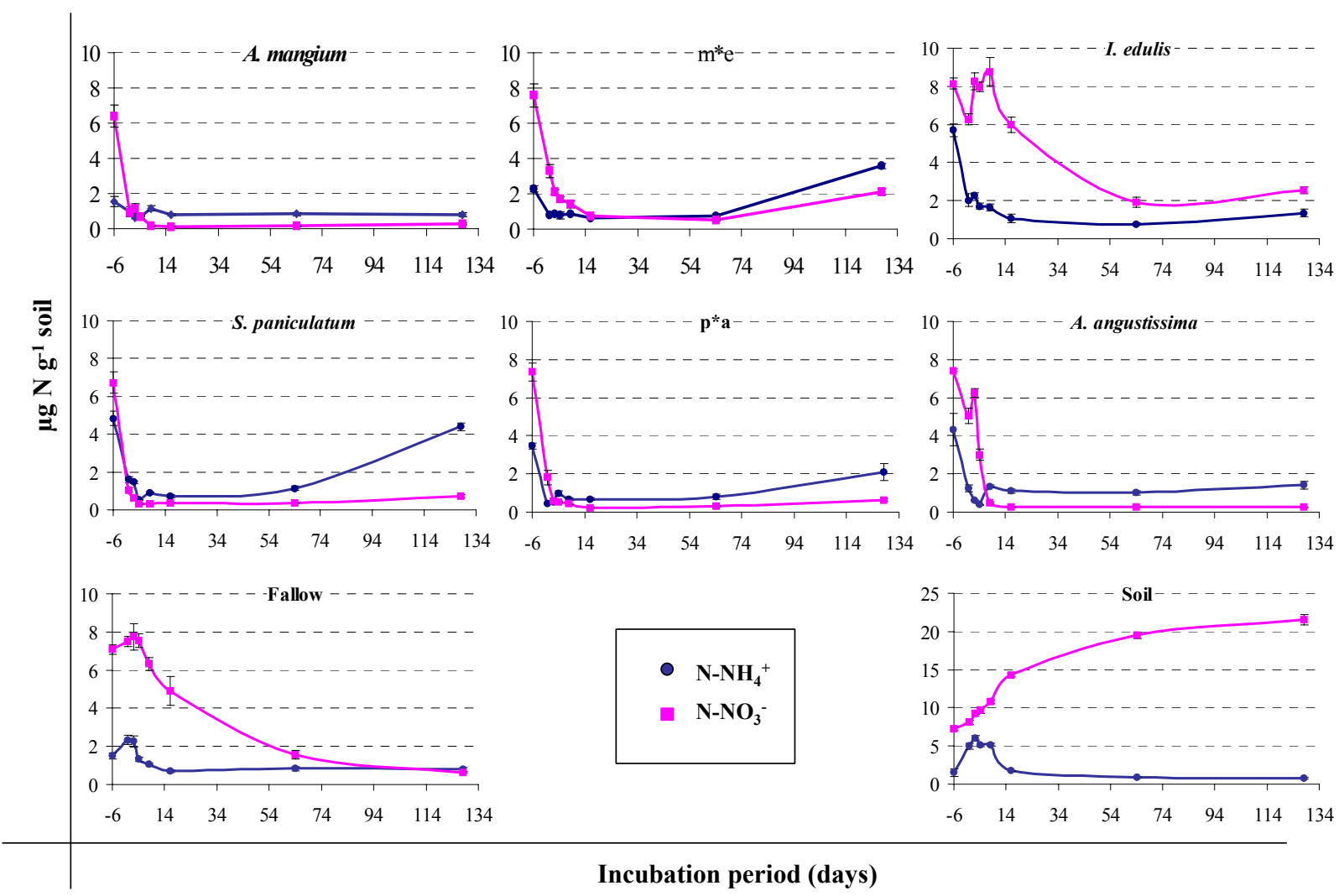

Figure 3. Concentration of mineral $\mathrm{N}$ as influenced by incorporated wood and leaves from different legumes species in comparison with fallow vegetation (Fallow) and soil with initial organic matter (Soil) as control. Bars represent standard error of the mean.

The proportional accumulative $\mathrm{NH}_{4}{ }^{+}-\mathrm{N}(\%)$ from added N-leaf + wood material for different treatment ranged from 10.7 to $23.7 \%$ of the added N (Table 6). Assuming that the remineralization was the same for all treatment, S. paniculatum and I. edulis appeared the better legume treatment, which had higher fractions of their organic $\mathrm{N}$ mineralised. The mixture of $A$. mangium, with higher initial cellulose and phenol content, and I. edulis, with higher initial $\mathrm{N}$ and $\mathrm{P}$ content, showed higher organic $\mathrm{N}$-mineralization than the same species alone (Table 6). 
Table 6. Proportion of initially added $\mathrm{N}$ mineralized plus immobilized ${ }^{\alpha}$ from in the leaf + wood material (as $\mathrm{NH}_{4}{ }^{+}-\mathrm{N} \%$ ) for different treatment during the incubation period.

\begin{tabular}{cccccccc}
\hline $\begin{array}{c}\text { Incubation } \\
\text { period }\end{array}$ & A. mangium & $\mathrm{m}^{*} \mathrm{e}^{¥}$ & I. edulis & $\begin{array}{c}S . \\
\text { paniculatum }\end{array}$ & $\mathrm{p}^{*} \mathrm{a}^{\S}$ & $\begin{array}{c}A . \\
\text { angustissima }\end{array}$ & Fallow \\
\cline { 2 - 8 }$($ days $)$ & & & \multicolumn{5}{c}{$\%$} \\
\hline 0 & 1.75 & 4.82 & 3.33 & 2.05 & 3.9 & 0.94 & 4.43 \\
16 & 1.65 & 2.33 & 1.36 & 0.95 & 1.14 & 0.72 & 3.93 \\
64 & 2.24 & 1.87 & 1.98 & 1.14 & 2.23 & 0.65 & 1.05 \\
128 & 4.33 & 3.49 & 1.75 & 5.24 & 3.04 & 1.02 & 1.43 \\
\cline { 2 - 8 } Total & 17.24 & 22.8 & 20.84 & 23.75 & 17.71 & 10.67 & 23.61 \\
\hline
\end{tabular}

${ }^{\alpha}$ The proportional $\mathrm{NH}_{4}{ }^{+}-\mathrm{N}$ mineralized plus immobilized was calculated with the sum of $\mathrm{NH}_{4}{ }^{+}-\mathrm{N}$ in soil and $\mathrm{N}$-microbial biomass in relation of initial added organic $\mathrm{N}$, expressed in percent.

${ }^{¥} \mathrm{~m} * \mathrm{e}$ represents mixture of $A$. mangium and $I$. edulis $(50: 50 \mathrm{w} / \mathrm{w})$.

${ }^{\S} \mathrm{p} *$ a represents mixture of $S$. paniculatum and $A$. angustissima $(50: 50 \mathrm{w} / \mathrm{w})$.

\subsubsection{Nitrogen mineralization and consumption}

Calculation of net ammonification $(a)$ and net nitrification $(n)$, in order to have a comparative parameters between treatments, was performed by subtracting soil $\mathrm{NH}_{4}{ }^{+}-\mathrm{N}$ in the time $x\left(t_{x}\right)$ from soil $\mathrm{NH}_{4}{ }^{+}-\mathrm{N}$ in the initial time $\left(t_{0}\right)$ and $\mathrm{NO}_{3}{ }^{-} \mathrm{N}$ in the time $x\left(t_{x}\right)$ from soil $\mathrm{NO}_{3}{ }^{-} \mathrm{N}^{-}$in the initial time $\left(t_{0}\right)$, respectively. Apparent microorganism $\mathrm{NH}_{4}{ }^{+}-\mathrm{N}$-immobilization ( $i$, Figure 4) was calculated by subtracting soil $\mathrm{NH}_{4}{ }^{+}-\mathrm{N}$ microbial biomass in the organic amendment treatment from $\mathrm{NH}_{4}{ }^{+}-\mathrm{N}$ microbial biomass in the control treatment (soil without organic amendment) (Jensen 1997), using the fumigation-extraction method. $\mathrm{N}-\mathrm{NO}_{3}^{-}$-consumption (c) was calculated by subtracting soil $\mathrm{N}-\mathrm{NO}_{3}{ }^{-}$in the control treatment from soil $\mathrm{N}-\mathrm{NO}_{3}{ }^{-}$in the organic amendment treatment. This is based on the assumption that the mineralization and losses of indigenous soil $\mathrm{N}$ were similar in control and residue-treated soils (Jensen 1997). 


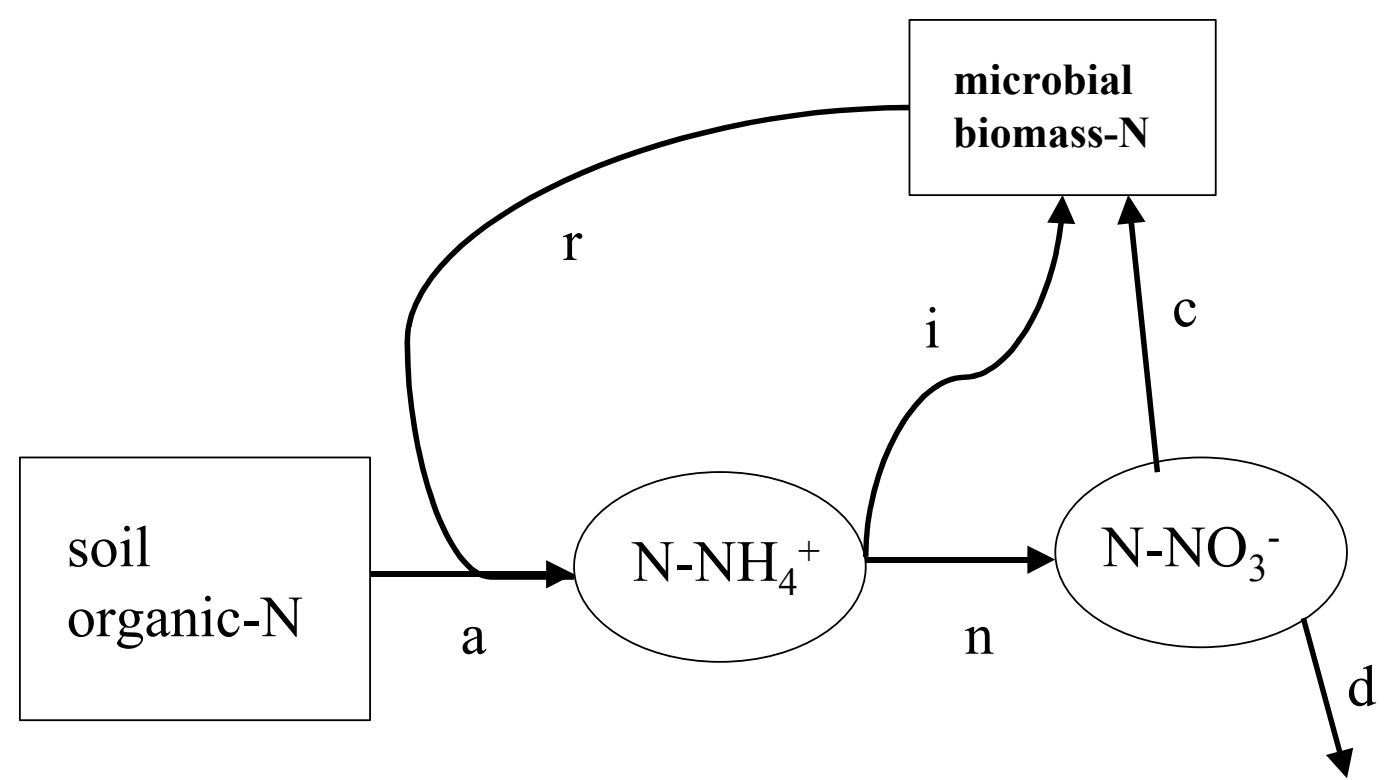

Figure 4. Flows of soil nitrogen indicated by: ( $a$ ) apparent $\mathrm{N}$-ammonification, $(r)$ apparent Nremineralization, (n) apparent $\mathrm{N}$-nitrification, $(i)$ apparent $\mathrm{NH}_{4}^{+}{ }_{4} \mathrm{~N}$ immobilization, $(c)$ apparent $\mathrm{N}-\mathrm{NO}_{3}^{-}$consumption, $(d)$ denitrification. Adapted from Stark and Schimel (2001).

\subsubsection{Apparent net $\mathrm{N}$-ammonification and $\mathrm{N}$-nitrification}

Both leguminous residues and the mixture of two contrasting species caused a net $\mathrm{N}$ immobilization of soil inorganic $\mathrm{N}$ during the complete incubation period of 128 days (Figure 5 A). Apparent net nitrogen ammonification of soil $\mathrm{N}$ showed significant differences during the incubation time $(\mathrm{P}<0.05)$ and between treatments $(\mathrm{P}<0.01)$. A low concentration of $\mathrm{NH}_{4}^{+}-\mathrm{N}$ is not necessary an indicator of low ammonification, because it can also indicate rapid nitrification or immobilization.

During the initial 64 days of decomposition, net $\mathrm{N}$-ammonification decreased for all treatments (Figure $5 \mathrm{~A}$ ). However, after half of the incubation period, $\mathrm{m}^{*}$ e mixture and $S$. paniculatum presented an increase in net $\mathrm{N}$-ammonification (Figure $5 \mathrm{~A}$ ). After 128 days of incubation, the higher net $\mathrm{N}$-ammonification of $\mathrm{m}^{*} \mathrm{e}$ mixture showed a strong difference $(\mathrm{P}<$ 0.01 ) from the other treatments. The inverse effect was observed in the other mixture comparison, but the higher net $\mathrm{N}$-ammonification was detected in the S. paniculatum treatment, which was different $(\mathrm{P}<0.01)$ from the $\mathrm{p}^{*}$ a mixture and $A$. angustissima. The lowest net $\mathrm{N}$-ammonification was presented by fallow treatment. 


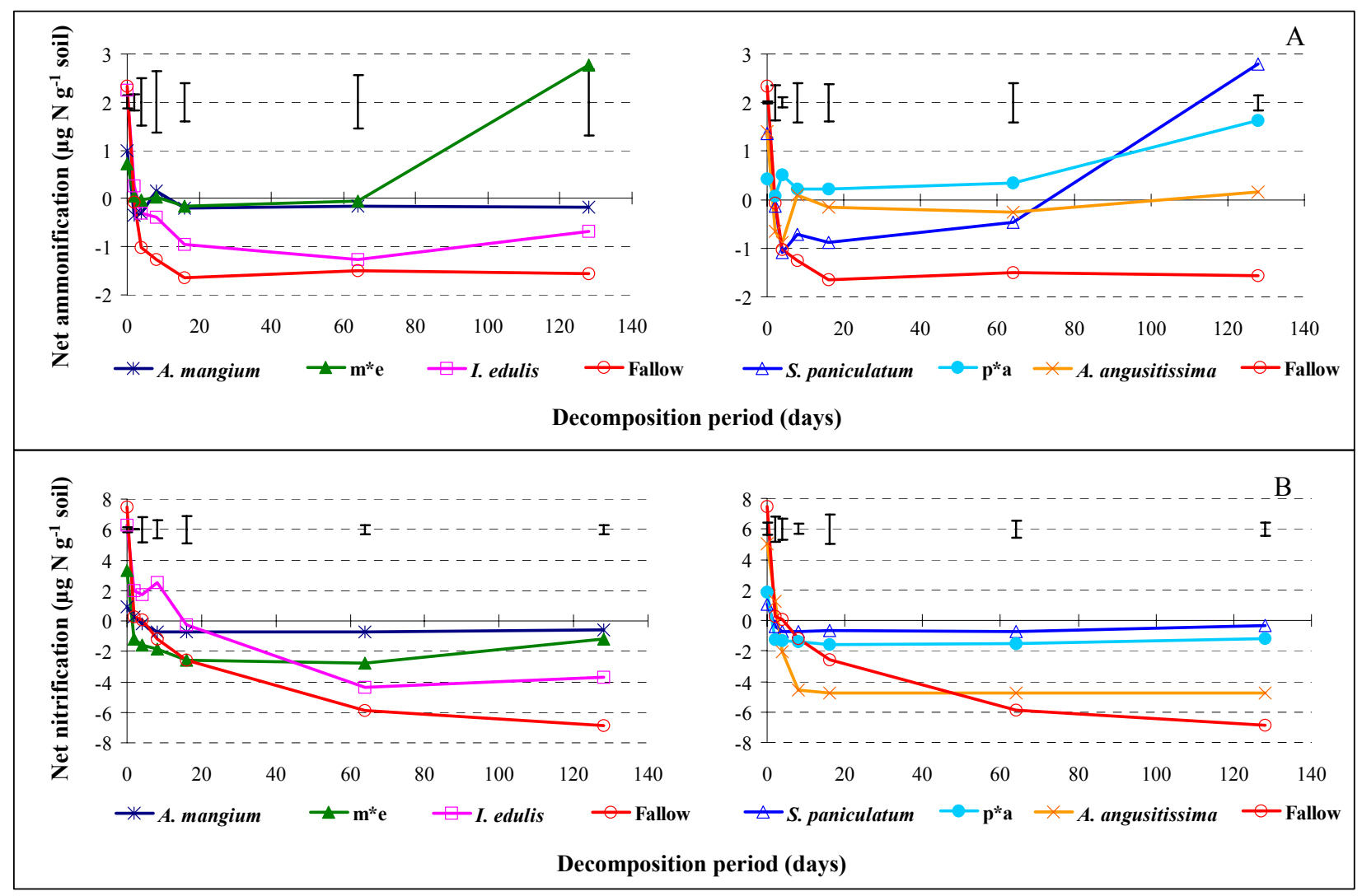

Figure 5. (A) Net ammonification of different legume residue-derived $\mathrm{N}$ in comparison to fallow residue-derived N. (B) Net nitrification of different legumes and mixture of residuesderived $\mathrm{N}$ in comparison to fallow residue-derived N. Bars represent LSD.

I. edulis and the fallow treatment had a significantly higher initial net nitrification rates $(\mathrm{P}<$ 0.01) in comparison to the other treatments (Figure 5 B). After 64 days of soil incubation net mineralization was constant, and only A. angustissima and the fallow treatment were significantly lower $(\mathrm{P}<0.01)$ than the other treatments (Figure $5 \mathrm{~B}$ ). As was the case for net $\mathrm{N}$ ammonification, the fallow treatment presented a lower net $\mathrm{N}$ nitrification after 64 days of decomposition period.

Apparent ammonification $(a)$ was significantly different $(\mathrm{P}<0.05)$ during the incubation period for the majority of treatments (Table 7). Only A. mangium did not show a significant difference in $\mathrm{N}$-ammonification between sampling times during the incubation period. The fallow and $I$. edulis treatments showed a significantly higher initial $\mathrm{N}$-ammonification. $A$. angustissima, S. paniculatum and A. mangium presented an intermediate initial Nammonification; with the mixture of two legume species presenting a significantly lower initial nitrogen ammonification (Table 7). 
Table 7. Apparent net $\mathrm{N}$-ammonification, $a\left(\mu \mathrm{g} \mathrm{NH}{ }_{4}^{+}-\mathrm{N} \mathrm{g}^{-1} \text { soil }\right)^{\Phi}$ as a function of time for different treatments.

\begin{tabular}{lcccc}
\hline \multirow{2}{*}{ Treatment } & \multicolumn{4}{c}{ Incubation period (days) } \\
\cline { 2 - 5 } & 0 & 16 & 64 & 128 \\
\hline A. mangium & $1.00^{\mathrm{a}}$ & $-0.21^{\mathrm{a}}$ & $-0.15^{\mathrm{a}}$ & $-0.18^{\mathrm{a}}$ \\
$\mathrm{m}^{*} \mathrm{e}$ & $0.73^{\mathrm{b}}$ & $-0.16^{\mathrm{c}}$ & $-0.05^{\mathrm{c}}$ & $2.76^{\mathrm{a}}$ \\
I. edulis & $2.25^{\mathrm{a}}$ & $-0.95^{\mathrm{b}}$ & $-1.26^{\mathrm{b}}$ & $-0.68^{\mathrm{b}}$ \\
S. paniculatum & $1.37^{\mathrm{b}}$ & $-0.87^{\mathrm{c}}$ & $-0.46^{\mathrm{c}}$ & $2.79^{\mathrm{a}}$ \\
$\mathrm{p}^{*} \mathrm{a}$ & $0.42^{\mathrm{ab}}$ & $0.23^{\mathrm{b}}$ & $0.34^{\mathrm{b}}$ & $1.63^{\mathrm{a}}$ \\
A. angustissima & $1.40^{\mathrm{a}}$ & $-0.16^{\mathrm{b}}$ & $-0.25^{\mathrm{b}}$ & $0.15^{\mathrm{b}}$ \\
Fallow & $2.34^{\mathrm{a}}$ & $-1.64^{\mathrm{b}}$ & $-1.50^{\mathrm{b}}$ & $-1.56^{\mathrm{b}}$ \\
\cline { 2 - 5 } LSD $_{\leq 0.05}$ & 0.67 & 0.68 & 0.80 & 1.16 \\
\hline
\end{tabular}

${ }^{\Phi}$ Apparent net $\mathrm{N}$-ammonification $(a)$ was calculated by subtracting soil $\mathrm{NH}_{4}{ }^{+}-\mathrm{N}$ in the time $n\left(t_{n}\right)$ from soil $\mathrm{NH}_{4}{ }^{+}-\mathrm{N}$ in the initial time $\left(t_{0}\right)$.

${ }^{¥}$ Values within a line that are followed by different letters are significantly different with the Tukey test $(\mathrm{P}<0.05)$.

Least significant difference (LSD) to compare treatments in the same sampling time.

The $\mathrm{m}^{*} \mathrm{e}$ mixture, $S$. paniculatum and $\mathrm{p} *$ a mixture showed a significantly higher increase in ammonification at the end of incubation period with 2.03, 1.42 and $1.21 \mu \mathrm{g} \mathrm{NH}_{4}{ }^{+}-\mathrm{N} \mathrm{g}^{-1}$ soil, respectively (Table 7). All other treatments showed a decrease in $\mathrm{N}$-ammonification, particularly so for the fallow and I. edulis i.e., -3.96 and $-2.93 \mu \mathrm{g} \mathrm{NH}_{4}{ }^{+}-\mathrm{N} \mathrm{g} \mathrm{g}^{-1}$ soil, respectively. The mixture of these two legume species was significantly better mineralizable than the single species. This interaction was not observed with the other mixture, where $S$ paniculatum showed a higher increase when mixed with A. angustissima.

The treatments with amendment showed a significant difference $(\mathrm{P}<0.05)$ in $\mathrm{N}$ nitrification during the incubation period (Table 8). Fallow vegetation, I. edulis and A. angustissima showed a significantly higher initial nitrification, with $\mathrm{m}^{*} \mathrm{e}, \mathrm{p}^{*}$ a mixture and $S$. paniculatum showing intermediate values, respectively (Table 8). However, a significantly higher nitrification decrease was found in the fallow, I. edulis and A. angustissima, with variations of 14.4, 10.0 and $9.8 \mu \mathrm{g} \mathrm{N}-\mathrm{NO}_{3}{ }^{-} \mathrm{g}^{-1}$ soil, respectively. A. mangium showed a significant lower initial $\mathrm{N}$ nitrification. At the end of the incubation period the mineralization decreased in the 
following order: $S$. paniculatum $\geq$ A. mangium $\geq \mathrm{m}^{*} \mathrm{e}=\mathrm{p}^{*} \mathrm{a}>I$. edulis $\geq$ A. angustissima $>$ Fallow vegetation ${ }^{11}$.

Table 8. Net $\mathrm{N}$ nitrification, $n\left(\mu \mathrm{g} \mathrm{NO}_{3}{ }^{-}-\mathrm{N} \mathrm{g}^{-1}\right.$ soil) ${ }^{\Phi}$ as a function of time for different treatment.

\begin{tabular}{lcccc}
\hline \multirow{2}{*}{ Treatment } & \multicolumn{4}{c}{ Incubation period (days) $^{¥}$} \\
\cline { 2 - 5 } & 0 & 16 & 64 & 128 \\
\hline A. mangium & $0.90^{\mathrm{a}}$ & $-0.76^{\mathrm{b}}$ & $-0.74^{\mathrm{b}}$ & $-0.62^{\mathrm{b}}$ \\
$\mathrm{m}^{*} \mathrm{e}$ & $3.29^{\mathrm{a}}$ & $-2.56^{\mathrm{b}}$ & $-2.78^{\mathrm{b}}$ & $-1.18^{\mathrm{b}}$ \\
I. edulis & $6.26^{\mathrm{a}}$ & $-0.28^{\mathrm{b}}$ & $-4.35^{\mathrm{c}}$ & $-3.73^{\mathrm{c}}$ \\
S. paniculatum & $1.05^{\mathrm{a}}$ & $-0.68^{\mathrm{b}}$ & $-0.71^{\mathrm{b}}$ & $-0.32^{\mathrm{b}}$ \\
$\mathrm{p}^{*} \mathrm{a}$ & $1.83^{\mathrm{a}}$ & $-1.60^{\mathrm{b}}$ & $-1.50^{\mathrm{b}}$ & $-1.18^{\mathrm{b}}$ \\
A. angustissima & $5.04^{\mathrm{a}}$ & $-4.79^{\mathrm{b}}$ & $-4.77^{\mathrm{b}}$ & $-4.79^{\mathrm{b}}$ \\
Fallow & $7.49^{\mathrm{a}}$ & $-2.57^{\mathrm{b}}$ & $-5.91^{\mathrm{c}}$ & $-6.89^{\mathrm{c}}$ \\
\cline { 2 - 5 } LSD $_{\leq 0.05}$ & 0.93 & 1.32 & 1.28 & 1.06
\end{tabular}

${ }^{\Phi}$ Net $\mathrm{N}$ nitrification $(n)$ was calculated by subtracting soil $\mathrm{NO}_{3}{ }^{-}-\mathrm{N}$ in the time $n\left(t_{n}\right)$ from soil $\mathrm{NO}_{3}{ }^{-}-\mathrm{N}$ in the initial time $\left(t_{0}\right)$.

${ }^{*}$ Values within a line that are followed by different letters are significantly different with the Tukey test $(\mathrm{P}<0.05)$.

Least significant difference (LSD) to compare treatments in the same sampling time.

The lower initial value net nitrification presented by $A$. mangium, $S$. paniculatum and $p^{*} a$ mixture treatment maybe due to the higher $\mathrm{NO}_{3}{ }^{-}$consumption in these treatments, which will be discussed below.

\subsubsection{Net nitrogen microbial immobilization and consumption}

Differences between the treatments were observed for $\mathrm{NH}_{4}{ }^{+}-\mathrm{N}$ immobilization at the beginning of the experiment $(\mathrm{P}<0.05)$ (Table 9). Control treatment ${ }^{12}$ decreased $\mathrm{NH}_{4}{ }^{+}-\mathrm{N}$ immobilization from $1.69 \mu \mathrm{g} \mathrm{NH}_{4}{ }^{+}-\mathrm{N} \mathrm{g} \mathrm{g}^{-1}$ soil in the time 0 to $0.27 \mu \mathrm{g} \mathrm{NH}_{4}{ }^{+}-\mathrm{N} \mathrm{g}^{-1}$ soil at the end of the incubation period. The $\mathrm{m}^{*} \mathrm{e}, \mathrm{p}^{*}$ a mixture and $I$. edulis treatments had a significantly higher initial $\mathrm{NH}_{4}{ }^{+}-\mathrm{N}$ immobilization (Table 9), and the treatments showed a lower initial C-to-N ratio in comparison to A. mangium and S. paniculatum (Table 2). $A$.

\footnotetext{
11 " $\geq$ " and "=" symbols means that the treatments did not show statistical difference $(\mathrm{P}>0.05)$, and " $>$ " symbol showed statistical difference $(\mathrm{P}<0.05)$.

${ }^{12}$ Control treatment mean soil without added organic material.
} 
angustissima also showed a low initial C-to-N ratio (38.9), which did not explain the low initial $\mathrm{N}$ immobilization, but this treatment had a higher initial phenol content (Table 4), which contributed to the low initial $\mathrm{N}$-immobilization (Mafongoya et al. 1998).

Table 9. Apparent net $\mathrm{N}$-microbial immobilization, $i\left(\mu \mathrm{g} \mathrm{NH}_{4}{ }^{+}-\mathrm{N} \mathrm{g}^{-1}\right.$ soil) ${ }^{\Phi}$ as a function of incubation period and treatment.

\begin{tabular}{lcccc}
\hline \multirow{2}{*}{ Treatment } & \multicolumn{4}{c}{ Incubation period (days) $^{¥}$} \\
\cline { 2 - 5 } & 0 & 16 & 64 & 128 \\
\hline A. mangium & $0.76^{\mathrm{b}}$ & $0.38^{\mathrm{b}}$ & $1.90^{\mathrm{b}}$ & $5.22^{\mathrm{a}}$ \\
$\mathrm{m}^{*} \mathrm{e}$ & $6.46^{\mathrm{a}}$ & $2.61^{\mathrm{b}}$ & $2.59^{\mathrm{b}}$ & $2.28^{\mathrm{b}}$ \\
I. edulis & $4.15^{\mathrm{a}}$ & $1.24^{\mathrm{c}}$ & $3.34^{\mathrm{ab}}$ & $2.59^{\mathrm{b}}$ \\
S. paniculatum & $1.16^{\mathrm{ab}}$ & $0.31^{\mathrm{b}}$ & $0.85^{\mathrm{ab}}$ & $2.34^{\mathrm{a}}$ \\
$\mathrm{p}^{*} \mathrm{a}$ & $5.92^{\mathrm{a}}$ & $1.02^{\mathrm{c}}$ & $3.28^{\mathrm{b}}$ & $3.44^{\mathrm{b}}$ \\
A. angustissima & $0.95^{\mathrm{ab}}$ & $0.19^{\mathrm{c}}$ & $0.90^{\mathrm{b}}$ & $1.40^{\mathrm{a}}$ \\
Fallow & $1.72^{\mathrm{ab}}$ & $2.44^{\mathrm{a}}$ & $0.65^{\mathrm{b}}$ & $1.33^{\mathrm{ab}}$ \\
\cline { 2 - 5 }$\quad$ LSD $_{\leq 0.05}$ & 0.96 & 0.21 & 0.25 & 1.26 \\
\hline
\end{tabular}

${ }^{\Phi}$ Apparent microorganism $\mathrm{NH}_{4}{ }^{+}-\mathrm{N}$ immobilization $(i)$ was calculated by subtracting soil $\mathrm{NH}_{4}{ }^{+}-\mathrm{N}$ microbial biomass in the organic amendment treatment from $\mathrm{NH}_{4}{ }^{+}-\mathrm{N}$ microbial biomass in the control treatment (soil without organic amendment).

${ }^{¥}$ Values within a line that are followed by different letters are significantly different with the Tukey test $(\mathrm{P}<0.05)$.

Least significant difference (LSD) to compare treatments in the same sampling time.

Only the $\mathrm{m}^{*} \mathrm{e}$ and $\mathrm{p}^{*}$ a mixtures as well as the I. edulis significantly decreased $(\mathrm{P}<0.05)$ in net $\mathrm{NH}_{4}{ }^{+}-\mathrm{N}$ immobilization at the end of incubation period. A. mangium showed a smaller initial net $\mathrm{NH}_{4}{ }^{+}-\mathrm{N}$ immobilization and a significantly higher $(\mathrm{P}<0.01)$ increase in the net $\mathrm{NH}_{4}{ }^{+}-\mathrm{N}$ immobilization at the end of incubation period.

Between 64 and 128 days of the incubation period, $\mathrm{NH}_{4}{ }^{+}-\mathrm{N}$ immobilization was not significantly different $(\mathrm{P}>0.05)$ for the $\mathrm{m}^{*} \mathrm{e}$, I. edulis, $\mathrm{p}^{*} \mathrm{a}$, A. angustissima, and Fallow treatments (Figure 6 A). However, for this same period, A. mangium and S. paniculatum experienced a stronger increase in $\mathrm{NH}_{4}{ }^{+}-\mathrm{N}$ immobilization, with 3.32 and $1.18 \mu \mathrm{g} \mathrm{NH}_{4}{ }^{+}-\mathrm{N} \mathrm{g}^{-1}$ soil, respectively. 


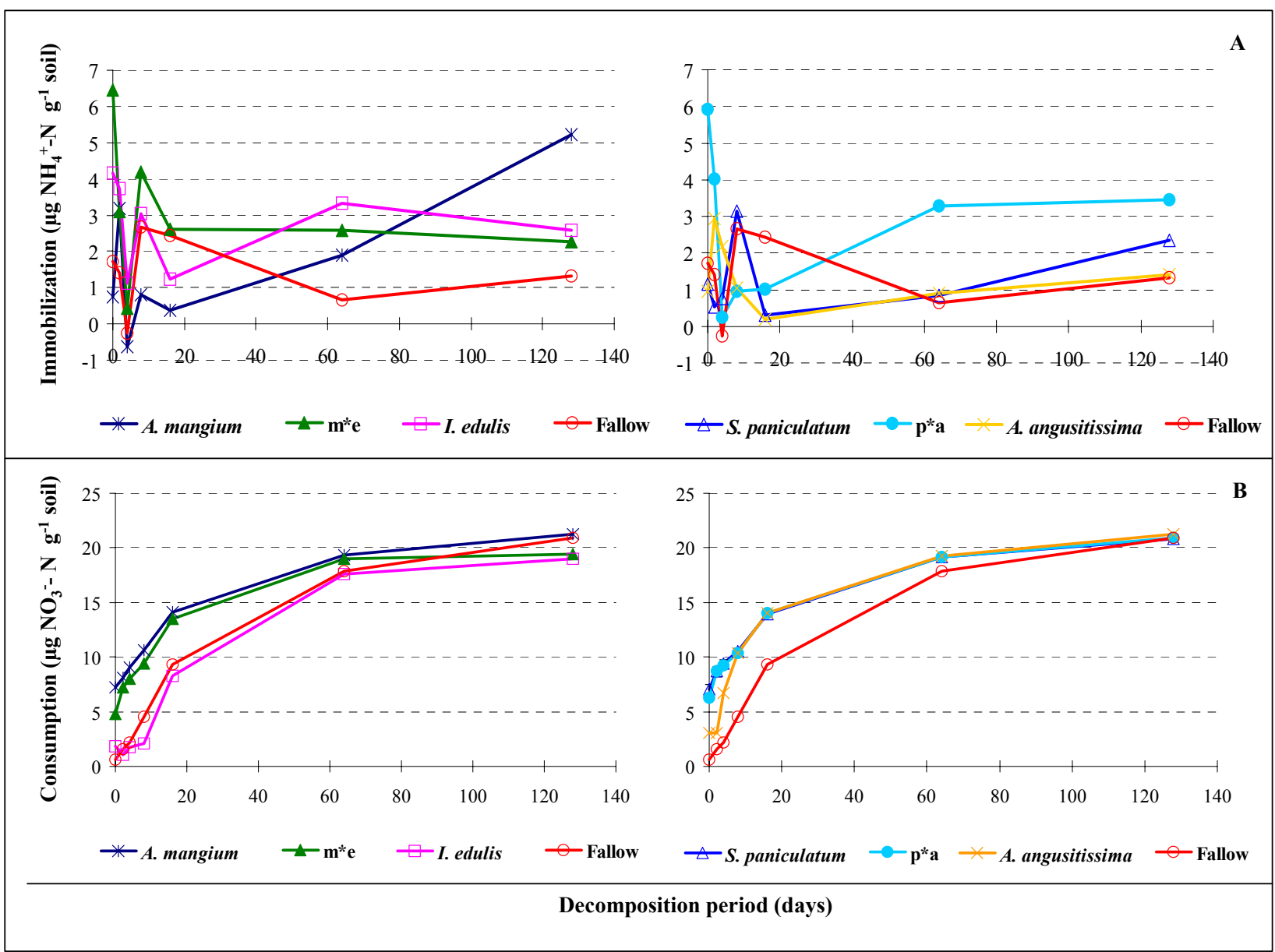

Figure 6. (A) $\mathrm{NH}_{4}{ }^{+}-\mathrm{N}$ microbial immobilization $\left(\mu \mathrm{g} \mathrm{NH}_{4}{ }^{+}-\mathrm{N} \mathrm{g}^{-1}\right.$ soil) and (B) apparent $\mathrm{NO}_{3}{ }^{-}-$ $\mathrm{N}$ microbial consumption in soil of different legumes and mixtures, of leaf and wood material incorporated in soil, during the decomposition period.

As with the net immobilization, the microbial consumption of $\mathrm{NO}_{3}{ }^{-} \mathrm{N}$ was noticeably different $(\mathrm{P}<0.01)$ between treatments at the beginning of the incubation period (Table 10). The strong differences in net consumption at the beginning of the experiment may reflect the differences in organic material quality. The A. mangium, S. paniculatum and p*a mixture treatment showed a significantly higher initial $\mathrm{NO}_{3}{ }^{-}-\mathrm{N}$ consumption, and fallow vegetation showed the lowest value at the same time. All treatments showed a significant elevation in $\mathrm{NO}_{3}{ }^{-}-\mathrm{N}$ consumption during the incubation period (Figure $6 \mathrm{~B}$ ). But I. edulis showed a significantly lower $\mathrm{NO}_{3}{ }^{-}-\mathrm{N}$ consumption $(\mathrm{P}<0.01)$ at the beginning of the experiment following by fallow treatment. 
Table 10. Apparent Net microbial consumption of $\mathrm{NO}_{3}{ }^{-}-\mathrm{N}, c\left(\mu \mathrm{g} \mathrm{NO}_{3}{ }^{-}-\mathrm{N} \mathrm{g}^{-1} \text { soil }\right)^{\Phi}$ as a function of incubation period and treatment.

\begin{tabular}{lcccc}
\hline \multirow{2}{*}{ Treatment } & \multicolumn{4}{c}{ Incubation period (days) $^{¥}$} \\
\cline { 2 - 5 } & 0 & 16 & 64 & 128 \\
\hline A. mangium & $7.20^{\mathrm{d}}$ & $14.13^{\mathrm{c}}$ & $19.33^{\mathrm{b}}$ & $21.24^{\mathrm{a}}$ \\
$\mathrm{m}^{* \mathrm{e}}$ & $4.81^{\mathrm{c}}$ & $13.54^{\mathrm{b}}$ & $18.97^{\mathrm{a}}$ & $19.41^{\mathrm{a}}$ \\
I. edulis & $1.84^{\mathrm{c}}$ & $8.29^{\mathrm{b}}$ & $17.57^{\mathrm{a}}$ & $18.99^{\mathrm{a}}$ \\
S. paniculatum & $7.05^{\mathrm{d}}$ & $13.90^{\mathrm{c}}$ & $19.14^{\mathrm{b}}$ & $20.79^{\mathrm{a}}$ \\
$\mathrm{p}^{*} \mathrm{a}$ & $6.27^{\mathrm{d}}$ & $14.04^{\mathrm{c}}$ & $19.15^{\mathrm{b}}$ & $20.87^{\mathrm{a}}$ \\
A. angustissima & $3.06^{\mathrm{d}}$ & $14.02^{\mathrm{c}}$ & $19.21^{\mathrm{b}}$ & $21.27^{\mathrm{a}}$ \\
Fallow & $0.61^{\mathrm{d}}$ & $9.35^{\mathrm{c}}$ & $17.90^{\mathrm{b}}$ & $20.91^{\mathrm{a}}$ \\
\cline { 2 - 5 }$\quad$ LSD $_{\leq 0.05}$ & 0.93 & 1.06 & 0.25 & $0.37^{-9.25}$ \\
\hline
\end{tabular}

${ }^{\Phi}$ Apparent net consumption $(c)$ was calculated by subtracting soil $\mathrm{NO}_{3}{ }^{-}-\mathrm{N}$ in the control treatment from soil $\mathrm{NO}_{3}{ }^{-} \mathrm{N}$ in the organic amendment treatment in the same incubation period.

${ }^{¥}$ Values within a line that are followed by different letters are significantly different with the Tukey test $(\mathrm{P}<0.05)$.

Least significant difference (LSD) to compare treatments in the same sampling time.

At the end of the experiment, a significantly lower apparent $\mathrm{NO}_{3}{ }^{-}-\mathrm{N}$ consumption was found in I. edulis and $\mathrm{m}^{*}$ e mixture (LSD < 0.05), in comparison the other treatment (Table 10). Only for these two treatments, $\mathrm{NO}_{3}{ }^{-}-\mathrm{N}$ consumption remained constant after 64 days of incubation. The significantly highest consumption of $20.3 \mu \mathrm{g} \mathrm{NO}_{3}{ }^{-}-\mathrm{N} \mathrm{g}^{-1}$ soil was found in the Fallow treatment.

In this study the data indicate that the decline of mineral-N was strongly influenced by immobilization and consumption of mineral $\mathrm{N}$ by the microflora. Microbial consumption of $\mathrm{NO}_{3}{ }^{-}-\mathrm{N}$ was of a greater magnitude than $\mathrm{NH}_{4}{ }^{+}-\mathrm{N}$ immobilization (Figure $6 \mathrm{~A}$ and $\mathrm{B}$ ). These results thus indicate that the decreases observed in net $\mathrm{N}$-mineralization were due to increasing consumption of N. However, immobilization into soil organic matter (SOM) may be attributed to the apparent net N-mineral loss (Bending et al. 1998).

As was shown by Verchot et al. (2001), the results shown in this experiment demonstrate that the patterns of $\mathrm{N}$-mineralization are dependent upon differences between microbial production and consumption. These processes are dependent on organic matter quality. Small changes in mineralization, nitrification, immobilization and consumption may possibly have a large impact on soil $\mathrm{N}$ availability for the crop. 


\subsubsection{Microbial biomass-C, extractable organic-C, and $\mathrm{CO}_{2}$ production}

In this study, total microbial biomass $\mathrm{C}$ measurements showed treatment effects (Figure 7A). The initial high increase in microbial biomass $\mathrm{C}$ can be explained by the strong decrease in the initial $\mathrm{N}$ concentration in the soil (Figure $7 \mathrm{~A}$ ). Two days after begin of the incubation period, the fallow treatment showed a significantly lower microbial biomass $\mathrm{C}$ in comparison to the other treatments. During the same period, A. mangium showed a higher microbial biomass $\mathrm{C}$, which was not statistically significantly different only from the $\mathrm{p}^{*}$ a mixture $(\mathrm{P}>$ $0.05)$.

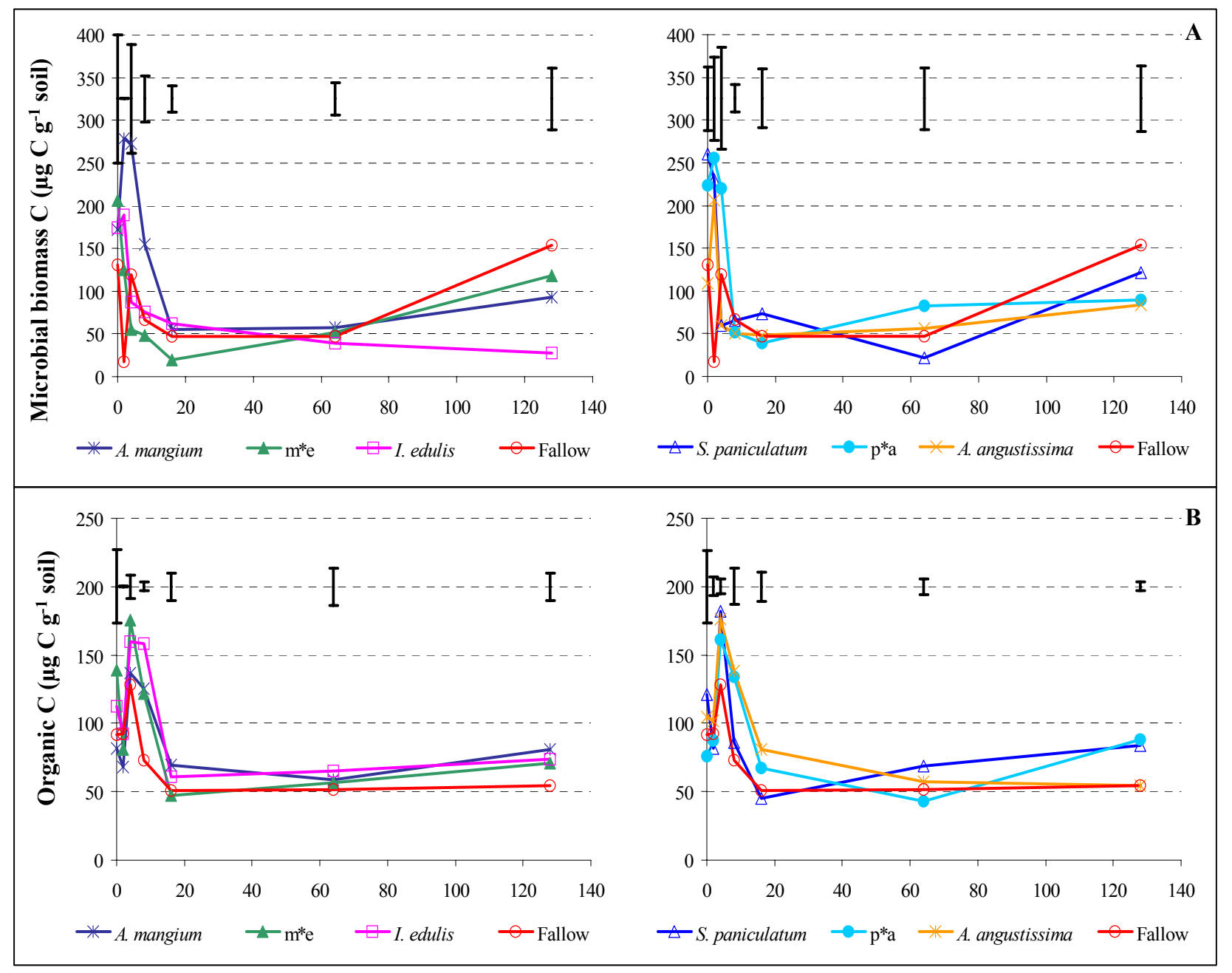

Decomposition period (days)

Figure 7. (A) Total microbial biomass C ( $\mu \mathrm{g} \mathrm{C} \mathrm{g}^{-1}$ soil) and (B) Extractable Organic carbon ( $\mu \mathrm{g} \mathrm{C}^{-1}$ soil) in soil with different legumes and mixture, of leaf and wood material incorporated in soil, during the decomposition period. Bars represent LSD.

All treatments showed a decrease in microbial biomass $\mathrm{C}$ the first 8 days of incubation, but $I$. edulis showed a higher decrease at the end of the incubation period, which amounted to a 
decrease of $147 \mu \mathrm{g} \mathrm{C} \mathrm{g}^{-1}$ soil. The other treatments showed an increase in microbial biomass $\mathrm{C}$ after eight days of the experiment until the end of the experiment.

Contrary from the results on microbial biomass $\mathrm{C}$, at the start of the experiment extractable organic $\mathrm{C}$ was significantly higher for the $\mathrm{m}^{*} \mathrm{e}$ and $I$. edulis treatments in comparison with the A. mangium treatment (Figure 7 B). A. mangium and fallow treatments showed an initial lower extractable organic $\mathrm{C}$ in comparison the other treatments. At the end of the incubation period $A$. angustissima and the fallow treatment showed a significantly lower extractable organic $\mathrm{C}$, and the other treatments did not show statistical differences. The Fallow treatment, with its higher level of mixtures, showed higher microbial biomass $\mathrm{C}$ and low extractable organic $\mathrm{C}$ at the end of the incubation period.

The principal loss of $\mathrm{C}$ from SOM is through respiration during decomposition (Woomer et al. 1994). All legume-amended soils showed significantly higher cumulative $\mathrm{CO}_{2}$ production than fallow-amended soil and the control treatment (soil) (Figure 8). The cumulative $\mathrm{CO}_{2}$ production was significantly higher for mixtures in comparison with the individual species.

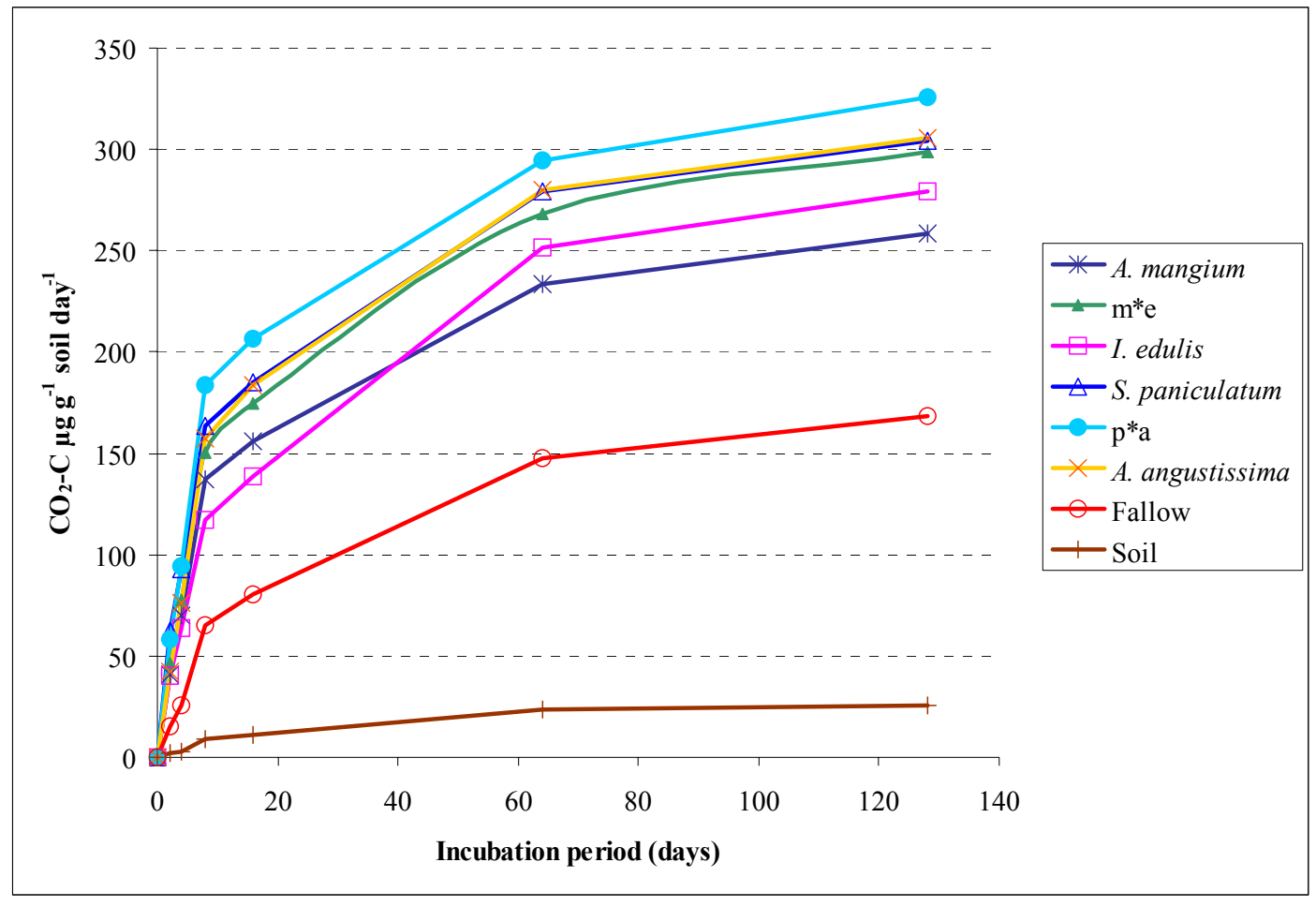

Figure 8. Accumulative $\mathrm{C}-\mathrm{CO}_{2}\left(\mu \mathrm{g} \mathrm{C} \mathrm{g}^{-1}\right.$ soil day $\left.{ }^{-1}\right)$ production during the incubation period for treatments with different organic matter soil added in comparison with soil without added organic matter as control (Soil).

All treatments showed a strong initial increase in $\mathrm{CO}_{2}-\mathrm{C}$ production, which resulted in a high slope of the accumulative $\mathrm{CO}_{2}-\mathrm{C}$ curve (Figure 8). It was conform the increase in the initial 
microbial $\mathrm{C}$ (Figure $7 \mathrm{~A}$ ), $\mathrm{NO}_{3}{ }^{-}$consumption (Figure $6 \mathrm{~B}$ ) and the high decrease in the initial $\mathrm{N}$ mineral (Figure 3).

In this experiment, soil $\mathrm{N}$ mineral decreased with increasing $\mathrm{CO}_{2}$ production and microbial biomass $\mathrm{C}$. In contrast, $\mathrm{N}$ immobilizations by microorganism increased with an increase in $\mathrm{CO}_{2}$ production due to added organic $\mathrm{C}$, and with a decrease of the $\mathrm{N}$ concentrations. This suggests that $\mathrm{N}$ dynamics in the legumes amended treatments were highly correlated with organic C dynamics (Figure 9).

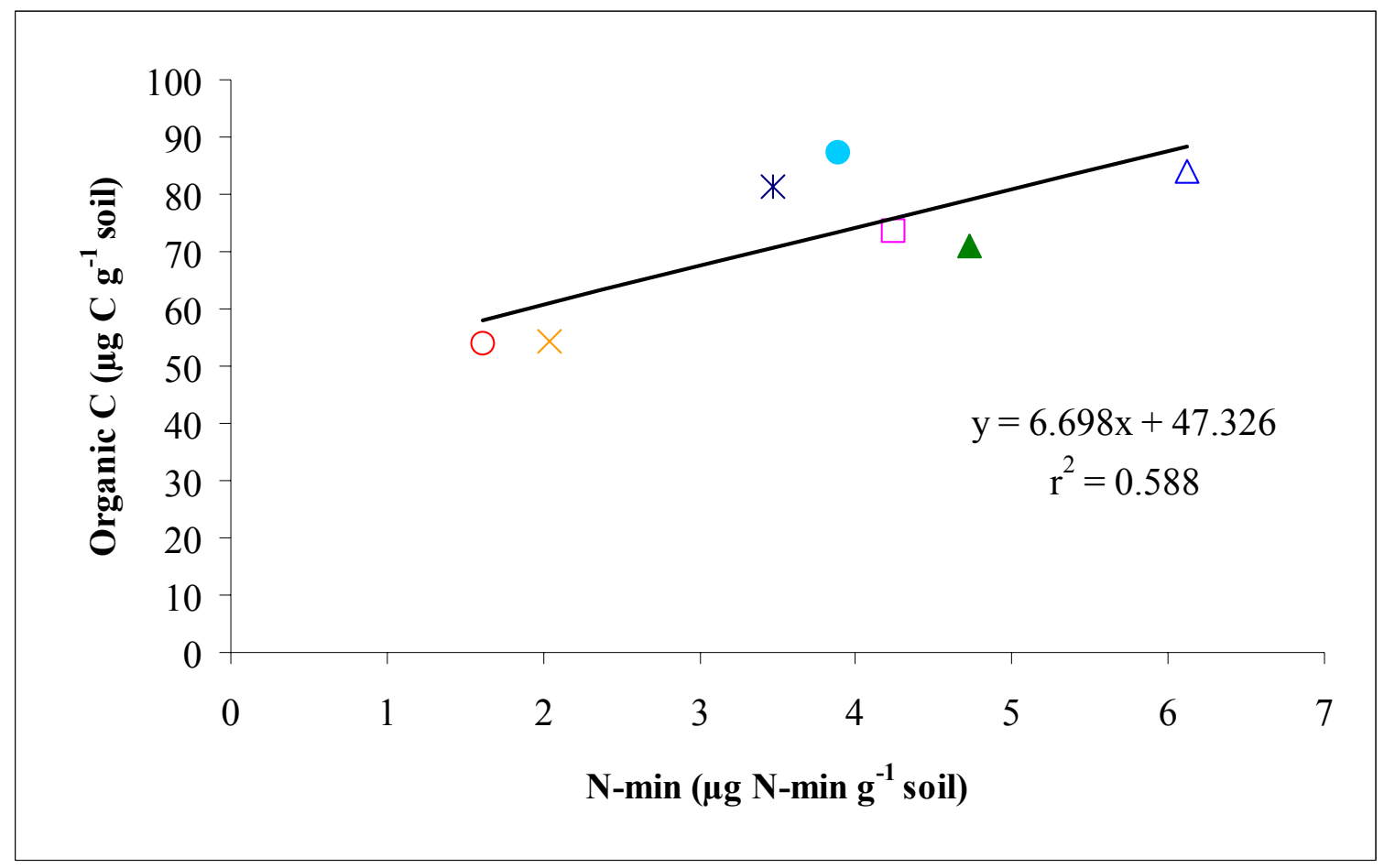

Figure 9. The relationship between mineral $\mathrm{N}(\mathrm{N}-\mathrm{min})$ and the extractable organic $\mathrm{C}$ resulting from treatment with different legumes, mixture and fallow at the end of incubation period (128 days). The symbols correspond to Fallow ( $\circ)$, A. angustissima $(\times)$, A. mangium $(*), \mathrm{p}^{*} \mathrm{a}$ mixture $(\odot)$, I. edulis $(\square)$, m*e mixture $(\Delta)$, S. paniculatum $(\triangle)$ treatment.

Since $\mathrm{N}$ immobilization is limited by substrate availability in a broad range of ecosystems and soil types, soil organic $\mathrm{C}$ concentration would strongly influence $\mathrm{N}$ immobilization (Barrett and Burke 2000). The correlation between nitrogen mineralization and carbon mineralization suggests that rapid stabilization of nitrogen is facilitated by an active microbial community and the availability of a readily mineralizable organic substrate. Critical levels of $\mathrm{C}$ and plant nutrients, which limit the enzyme activities of microbial decomposition, were found to be important for determining nutrient release (Seneviratne 2000). Soil microbial biomass has been defined as an indicator of soil fertility, long before changes is soil organic matter occur 
(Powlson and Brookes 1987). Microbial nitrogen $\mathrm{NH}_{4}{ }^{+}$immobilization and $\mathrm{NO}_{3}{ }^{-}$consumption appears to be an important variable that needs to be taken into account in studying organic matter decomposition and $\mathrm{N}$ mineralization.

The best predictor of $\mathrm{N}$-mineralization was phenol + lignin when all treatments were included in the analyses (Table 11), followed by phenol + lignin-to-N ratios and lignin. Initial N + P-tophenol ratios were highly correlated with cumulative N-mineralization for leguminous species and mixtures (Table 11).

Table 11. Correlation coefficients relating the cumulative amount of $\mathrm{N}$-mineralization to initial chemical properties in the treatments.

\begin{tabular}{|c|c|c|c|c|c|}
\hline Object of analyze & Lignin & Phenol + Lignin & $\frac{\text { Phenol + Lignin }}{\mathrm{N}}$ & $\frac{\text { Phenol }}{\mathrm{N}}$ & $\frac{\mathrm{N}+\mathrm{P}}{\text { Phenol }}$ \\
\hline All treatment ${ }^{\Phi}$ & $-0.812^{*}$ & $-0.826^{*}$ & $-0.819^{*}$ & & \\
\hline Legume and mixture $\Omega$ & $-0.813^{*}$ & $-0.798^{*}$ & $-0.768^{*}$ & $-0.830^{*}$ & $0.950^{* *}$ \\
\hline Single legumes ${ }^{\delta}$ & $-0.788^{*}$ & $-0.871^{*}$ & $-0.868^{*}$ & $-0.803^{*}$ & $0.916^{*}$ \\
\hline
\end{tabular}

\footnotetext{
${ }^{\Phi}$ All treatment means legumes, mixture and fallow treatments.

$\Omega$ mixture means mixture of two legume species.

${ }^{\delta}$ Single legume means legumes species without mixtures treatments. The $*$ is $\mathrm{P} \leq 0.05$, ** is $\mathrm{P} \leq 0.01$
}

Soil-incorporated plant lignins degrade to polyphenol, which, with the other plant and microbial polyphenol, become the main constituents of recalcitrant $\mathrm{N}$, containing humic polymers (Haynes 1986). Lignin intertwines also with the cell wall, physically protecting cellulose and other cell wall constituents from degradation (Chesson 1997).

Polyphenols include a range of compounds differing in size, solubility, and reactivity. Also, polyphenol can serve as a carbon substrate for decomposers (Mafongoya et al. 1998) but in general they inhibit the growth or function of decomposers and the other organisms (Swift et al. 1981, Zucker 1982). Defense compounds, including phenolics and terpenoids can also influence rates of litter decomposition, by means of direct inhibitor effects on saprophytic organisms (Palm and Sanchez 1991). Condensed tannins, also known as proanthocyanidins, are the polyphenol most noted for their effects on decomposition and nutrient dynamics. This results from their reactions with proteins and nitrogen (Myers et al. 1994; Mafongoya et al. 1998).

This experiment confirms that the resource quality and mixture of contrasting resource quality affect the $\mathrm{N}$-mineralization and -immobilization processes during decomposition. In agreement with Palm (1995), the following factors must be considered when choosing 
parameters to describe plant quality: a) the processes of decomposition and $\mathrm{N}$ release are controlled by different parameters; b) the critical parameters will depend on the time frame of the crop need; and c) the importance of certain parameters change with the type and the mixture of the plant material. The ultimate aim is to identify robust parameters that predict decomposition and nutrient release.

The decomposition patterns and N-mineralization of the mixture were not the arithmetic mean of the decomposition patterns of the component organic material. In this case, there are interactions between components principally in terms of the rate of decomposition and $\mathrm{N}$ release, which was demonstrated in N-mineralization (net and total mineralization), microbial biomass $\mathrm{C}$ and extractable organic $\mathrm{C}$.

Mafagoya et al. (1998) identified three types of soluble constituents that result in interactions between organic material: a) compounds that contain available carbon as a substrate, b) compounds that contain readily available $\mathrm{N}$, and c) soluble polyphenols, which can complex with proteins, rendering them resistant to microbial assault. The results showed in this experiment confirm that the carbon availably and soluble polyphenols may be the important parameters that result in interaction between contrasting organic material.

The I. edulis yielded the highest N-mineralization whereas $S$. paniculatum showed the better interaction with other leguminous species in terms of $\mathrm{N}$-mineralization and -immobilization. Therefore these species were chosen for subsequent studies on the comparison of contrasting species in relation to gross $\mathrm{N}$-mineralization and -immobilization.

\subsection{Laboratory study on decomposition and $\mathbf{N}$ dynamics of contrasting leguminous leaf material incorporated in soil}

Leaf material from two different legume species (S. paniculatum, I. edulis) and a mixture of leaf material from these two species ( $\mathrm{p}^{*}$ e mixture) was incorporated in soil with approximately the same amount of $\mathrm{N}$ resulting in different amounts of leaf dry matter and quality (Table 12 and 13). The difference between non-enriched ${ }^{13} S$. paniculatum ${ }^{14}$ and ${ }^{15} \mathrm{~N}$ enriched $S$. paniculatum ${ }^{15}$ (older and younger material, respectively) and I. edulis ${ }^{14}$ and $I$. edulis $^{15}$ (older and younger material, respectively) amounted to $1.51 \mathrm{~g}$ leaf material for species with older material, and $0.26 \mathrm{~g}$ of leaf material for the same species with younger

\footnotetext{
${ }^{13}$ Legume species ${ }^{14}$ mean organic material with $\mathrm{N}$ at natural abundance, and legume species ${ }^{15}$ mean organic material with enriched ${ }^{15} \mathrm{~N}$.
} 
material. This was due to the fact that $S$. paniculatum and I. edulis with enriched N (younger trees) showed a significantly $(\mathrm{P}<0.05)$ lower $\mathrm{N}$ concentration in comparison to the same species not enriched in ${ }^{15} \mathrm{~N}$ (older trees).

Table 12. Initial amount of soil $(\mathrm{g})$, leaf amended material $(\mathrm{g})$ with nitrogen content $\left(\mathrm{mg} \mathrm{N} \mathrm{g}^{-1}\right.$ soil), added $\mathrm{N}$-urea chemical fertilizer ( $\mathrm{mg} \mathrm{N} \mathrm{g}^{-1}$ soil), and resulting ${ }^{15} \mathrm{~N}$ excess $\left(\mu \mathrm{g}{ }^{15} \mathrm{~N}\right.$ excess $\mathrm{g}^{-1}$ soil) in soil with different legume treatments and mixtures in laboratory incubation experiments ${ }^{14}$. Control was the same soil without organic matter and fertilized with ${ }^{14} \mathrm{~N}$-urea. The numbers represent mean (standard deviation) with $\mathrm{n}=15$.

\begin{tabular}{|c|c|c|c|c|c|}
\hline \multirow[t]{2}{*}{ Treatment } & Soil & Leaf & $\begin{array}{c}\mathrm{N} \text { in added } \\
\text { leaf material }\end{array}$ & $\begin{array}{l}\mathrm{N} \text { in added urea } \\
\text { fertilizer }\end{array}$ & \multirow{2}{*}{$\begin{array}{r}{ }^{15} \mathrm{Nexcess}^{\alpha} \\
\text { amended }\end{array}$} \\
\hline & \multicolumn{2}{|c|}{$\mathrm{g}$} & \multicolumn{2}{|c|}{$\mathrm{mg} \mathrm{g}^{-1}$ soil } & \\
\hline S. paniculatum ${ }^{14}$ & $60.56(0.13)$ & $4.43(0.02)$ & $1.64(0.01)$ & $0.06(0.0001)$ & $2.97(0.0015)$ \\
\hline $\mathrm{p}^{*} \mathrm{e}^{14}$ & $60.62(0.20)$ & $3.79(0.05)$ & $1.70(0.02)$ & $0.06(0.0002)$ & $2.97(0.0010)$ \\
\hline I. edulis ${ }^{14}$ & $60.65(0.13)$ & $2.92(0.00)$ & $1.65(0.00)$ & $0.06(0.0002)$ & $2.97(0.0011)$ \\
\hline S. paniculatum ${ }^{15 \Omega}$ & $60.60(0.15)$ & $4.61(0.03)$ & $1.51(0.01)$ & $0.06(0.0025)$ & $0.39(0.0005)$ \\
\hline $\mathrm{p}^{*} \mathrm{e}^{15}$ & $60.61(0.08)$ & $4.53(0.02)$ & $1.52(0.01)$ & $0.06(0.0014)$ & $0.36(0.0006)$ \\
\hline I. edulis ${ }^{15}$ & $60.60(0.10)$ & $4.35(0.02)$ & $1.55(0.01)$ & $0.06(0.0017)$ & $0.38(0.0002)$ \\
\hline Control & $60.68(0.16)$ & & & $0.06(0.0003)$ & \\
\hline
\end{tabular}

${ }^{14}$ after species name means that the treatment was added leaf material (older material) with ${ }^{15} \mathrm{~N}$ at natural abundance $\left(0.3663\right.$ atom $\left.\%{ }^{15} \mathrm{~N}\right)$ and was fertilized with enriched ${ }^{15} \mathrm{~N}$-urea $\left(5.320\right.$ atom $\left.\%{ }^{15} \mathrm{~N}\right)$. ${ }^{15}$ after species name means that the treatment was added previously ${ }^{15} \mathrm{~N}$-enriched leaf material (younger material) and was fertilized with ${ }^{14} \mathrm{~N}$-urea.

${ }_{a}^{15} \mathrm{~N}$ excess signify the amount of enriched atom $\%{ }^{15} \mathrm{~N}$ minus ${ }^{15} \mathrm{~N}$ at natural abundance $(0.3663$ atom $\left.\%{ }^{15} \mathrm{~N}\right)$

The total of added leaf material ${ }^{15}$ ranged from $28.9 \mathrm{Mg} \mathrm{ha}^{-1}(1 \mathrm{Mg}=1$ ton $)$ in the I. edulis ${ }^{14}$ treatment to $45.6 \mathrm{Mg} \mathrm{ha}^{-1}$ in the $S$. paniculatum ${ }^{15}$ treatment. In the same way, total $\mathrm{N}$ added with leaf material ranged from $0.91 \mathrm{Mg} \mathrm{ha}^{-1}$ for S. paniculatum ${ }^{15}$ treatment to $1.0 \mathrm{Mg} \mathrm{ha}^{-1}$ for $\mathrm{p}^{*} \mathrm{e}^{14}$ mixture treatment. Using the same extrapolation, the total of $\mathrm{N}$ with chemical fertilization was approximately $0.36 \mathrm{Mg} \mathrm{ha}^{-1}$.

\footnotetext{
${ }^{14}$ Experiments with two differently-aged legume materials.

${ }^{15}$ Assumed that 1 ha contain $0.610^{3} \mathrm{Mg}$ soil between 0 and $5 \mathrm{~cm}$ of depth.
} 
The differences in ${ }^{15} \mathrm{~N}$ excess observed in the same species in these two experiments (Table 12) are based on the fact that the $\mathrm{N}$ in legume material at natural abundance received ${ }^{15} \mathrm{~N}$-urea with 5.32 atom $\%{ }^{15} \mathrm{~N}$ and the ${ }^{15} \mathrm{~N}$ excess found in enriched legume plant material was between 0.3919 atom $\%{ }^{15} \mathrm{~N}$ for S. paniculatum and 0.3904 atom $\%{ }^{15} \mathrm{~N}$ for I. edulis.

Similar to the N concentration described above, some chemical characteristics showed difference in concentration between the two experiments with the same species (Table 13). These differences probably resulted from the different plant ages (Constantinides and Fownes 1994a), reflecting principally the different amounts of leaf material added in this experiment (Table 12). The older material with $\mathrm{N}$ at natural abundance originates from 30 -month-old plants (Brienza 1999), and the younger material with enriched ${ }^{15} \mathrm{~N}$ from a 17 -month experiment (Paparcikova et al. 2000).

Table 13. Chemical characteristics of leaf material from different legume treatments and plant ages added to soil in laboratory incubation experiment. The numbers represent Mean(Standard deviation) with $\mathrm{n}=15$.

\begin{tabular}{llcrc}
\hline \multirow{2}{*}{ Treatment } & \multicolumn{1}{l}{ Lignin } & Cellulose & Phenolic & P \\
\cline { 2 - 5 } & \multicolumn{4}{c}{$\mathrm{mg} \mathrm{g}^{-1}$ soil } \\
\hline S. paniculatum $^{14}$ & $26.0(0.13)$ & $13.3(0.07)$ & $6.1(0.03)$ & $0.07(0.0001)$ \\
$\mathrm{p}^{*} \mathrm{e}^{14}$ & $21.7(0.29)$ & $12.0(0.16)$ & $5.1(0.07)$ & $0.08(0.0012)$ \\
I. edulis $^{14}$ & $16.1(0.05)$ & $9.9(0.02)$ & $3.9(0.01)$ & $0.10(0.0009)$ \\
S. paniculatum $^{15}$ & $19.8(0.13)$ & $12.7(0.09)$ & $6.4(0.04)$ & $0.07(0.0004)$ \\
$\mathrm{p}^{*} \mathrm{e}^{15}$ & $21.1(0.07)$ & $14.5(0.05)$ & $6.1(0.02)$ & $0.10(0.0003)$ \\
I. edulis $^{15}$ & $22.0(0.09)$ & $15.9(0.06)$ & $5.7(0.02)$ & $0.14(0.0004)$
\end{tabular}

${ }^{14}$ after species name means that the treatment was given leaf material (older material) with ${ }^{15} \mathrm{~N}$ at natural abundance $\left(0.366\right.$ atom $\left.\%{ }^{15} \mathrm{~N}\right)$ and was fertilized with enriched ${ }^{15} \mathrm{~N}$-urea $\left(5.320\right.$ atom $\left.\%{ }^{15} \mathrm{~N}\right)$. ${ }^{15}$ after species name means that the treatment was given previously ${ }^{15} \mathrm{~N}$-enriched leaf material (younger material) and was fertilized with ${ }^{14} \mathrm{~N}$-urea.

In the S. paniculatum ${ }^{14}$ treatment (older material) showed $37.9 \%$ higher lignin, $25.6 \%$ higher cellulose, $37.1 \%$ higher phenol, and $30.0 \%$ lower P concentrations when compared with $I$. edulis ${ }^{14}$ material of the same age (Table 13). However, in soil amended with younger material, I. edulis showed the higher concentrations of lignin (10.0\%), cellulose $(20.5 \%)$ and $\mathrm{P}(50.0 \%)$, and a lower phenol concentration (9.7\%). The lignin, cellulose and phenol concentrations were not significantly different $(\mathrm{P}>0.05)$ between $S$ paniculatum and the $\mathrm{p}^{*} \mathrm{e}$ mixture. 
For these two experiments (concerning the differences in methodology - see methods) the $S$. paniculatum amended material showed only a decrease in the phenol concentration with increasing age of the material, whereas I. edulis showed only an increase in the $\mathrm{N}$ content with the same increase in age (Table 13). The mixture of legume material showed an increase only in $\mathrm{N}$ concentration with the increase of age.

\subsubsection{Nitrogen mineralization and immobilization in soil}

\subsubsection{Total nitrogen mineral (N-min) in soil}

Total N-mineral (N-min) in the soil showed a different pattern between the different plant material ages and species when the same amount of $\mathrm{N}$ in organic matter was added (Figure 10 A and B), especially in the I. edulis treatment. In general, a diminution of added leaf material of $1.7,7.3$ and $28.9 \mathrm{Mg} \mathrm{ha}^{-1}$ for S. paniculatum, $\mathrm{p}^{*} \mathrm{e}$ mixture and I. edulis treatment, respectively, resulted in a significant $(\mathrm{P}<0.01)$ increase in the initial total $\mathrm{N}$-min concentration in the soil. In both the S. paniculatum and the I. edulis treatments, a higher initial total $\mathrm{N}$ mineral concentration in the experiment with older leaf material (Figure $10 \mathrm{~A}$ ) was observed compared to the experiments with younger leaf material (Figure $10 \mathrm{~B}$ ), when the same initial amount of $\mathrm{N}$ was used.

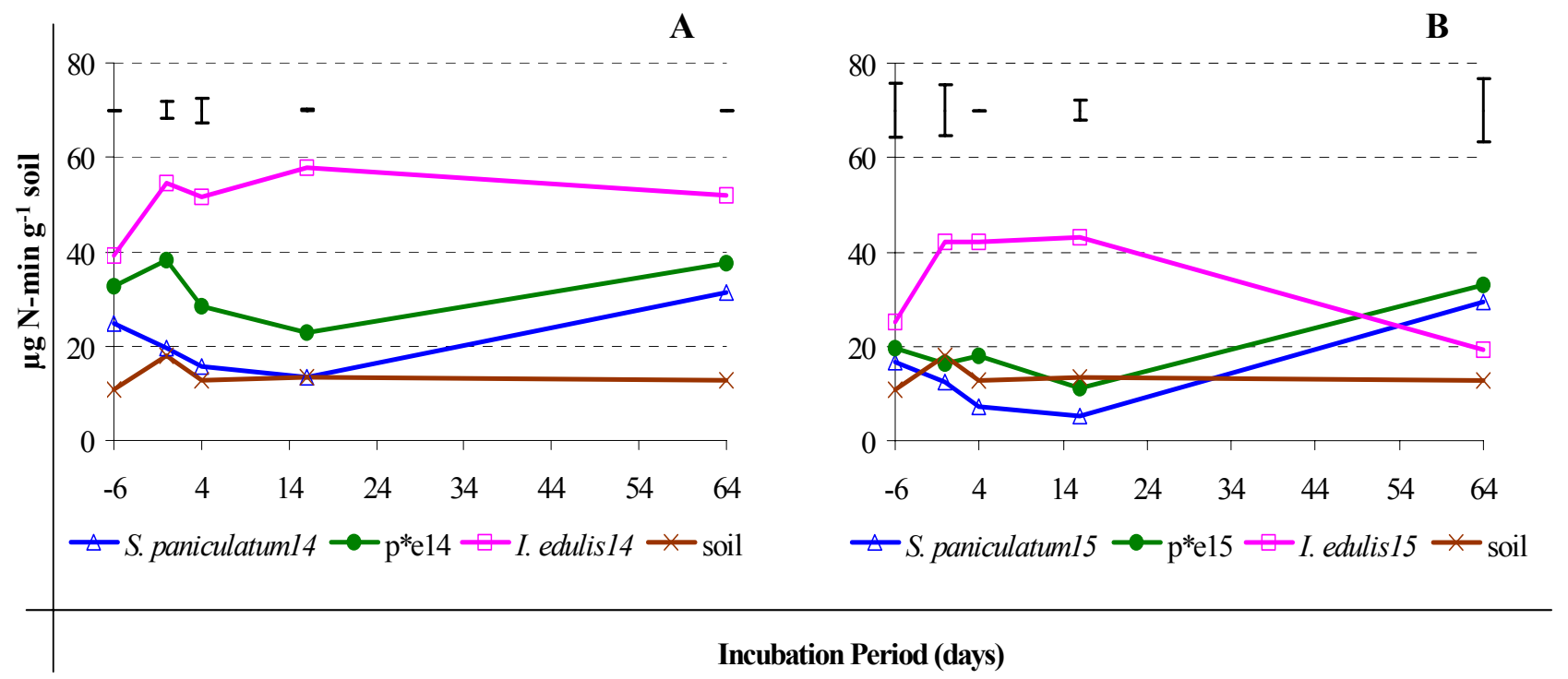

Figure 10. (A) Total nitrogen mineralization $\left(\mu \mathrm{g}\left({ }^{14} \mathrm{~N}+{ }^{15} \mathrm{~N}\right)-\mathrm{Nmin} \mathrm{g}^{-1}\right.$ soil $)$ during the laboratory incubation period (days) for samples with ${ }^{14} \mathrm{~N}$ leaf material and fertilized with enriched ${ }^{15} \mathrm{~N}$-urea $\left({ }^{14}\right.$ after species name), and (B) samples with ${ }^{15} \mathrm{~N}$ enriched leaf material and fertilized with ${ }^{14} \mathrm{~N}$-urea $\left({ }^{15}\right.$ after species name). Soil control was soil without leaf material and fertilized with ${ }^{14} \mathrm{~N}$-urea. The bars represent $\mathrm{LSD}_{<0.05}$. 
Initial significant differences $(\mathrm{P}<0.01)$ were observed in the experiment with older material (Figure $10 \mathrm{~A}$ ), where I. edulis showed a higher initial N-min; this difference increased until day 16 of the incubation period (Figure $10 \mathrm{~A}$ and B). In contrast, the S. paniculatum and the $\mathrm{p}^{*}$ e mixture treatments showed a decrease in the N-min concentration for the same period. The control showed an approximately constant N-min during the incubation period, but at the beginning of the experiment, between days 4 and 16 of the incubation period, this treatment showed a significantly higher N-min concentration than that of the $S$. paniculatum treatment, where younger leaf material was used (Figure $10 \mathrm{~B}$ ).

The mixture of leaf material from two legume species showed a similar N-min concentration pattern to that in the S. paniculatum treatment for both experiments (two different ages). At the end of the experiment, both the mixture and the pure S. paniculatum treatments showed a significantly $(\mathrm{P}<0.01)$ higher increase in the $\mathrm{N}$-min concentration. In the I. edulis treatment with the younger material, a greater decrease in the N-min concentration at the end of the experiment (Figure $10 \mathrm{~B}$ ) was observed than in that with older leaf material (Figure $10 \mathrm{~A}$ ). Since immobilization and consumption of $\mathrm{N}$ is generally determined by the amount of decomposable carbon present in the soil rather than by the amount of inorganic $\mathrm{N}$, the addition of wood material with a wide $\mathrm{C}$-to- $\mathrm{N}$ ratio accelerates $\mathrm{N}$ immobilization and consumption through increased microbial activity (Hadas et al. 1996). Thus, $\mathrm{N}$ availability to the crop and microbial immobilization and consumption of $\mathrm{N}$-urea differ, depending on the amount and the quality of added organic material in the soil.

\subsubsection{Nitrogen mineralization $\left(\mathrm{NH}_{4}{ }^{+}-\mathrm{N}\right.$ concentration) in soil}

The initial mineralization $\left(\mathrm{NH}_{4}{ }^{+}-\mathrm{N}\right.$ concentration) generated the same pattern of total $\mathrm{N}-\mathrm{min}$ concentrations described above (Figure $11 \mathrm{~A}$ and B). The initial differences in $\mathrm{NH}_{4}{ }^{+}-\mathrm{N}$ between the leaf materials with the different ages were observed in the three treatments with amended leaf material. In the two experiments, I. edulis showed an initial higher increase in mineralization until day 16 of the incubation period (Figure $11 \mathrm{~A}$ and $\mathrm{B}$ ). However, after this date, in both experiments a decrease in the $\mathrm{NH}_{4}{ }^{+}-\mathrm{N}$ concentration was observed. During the same period, the $\mathrm{p}^{*}$ e mixture and S. paniculatum treatments showed a decrease in mineralization, whereas the control treatment remained more or less constant. 
A

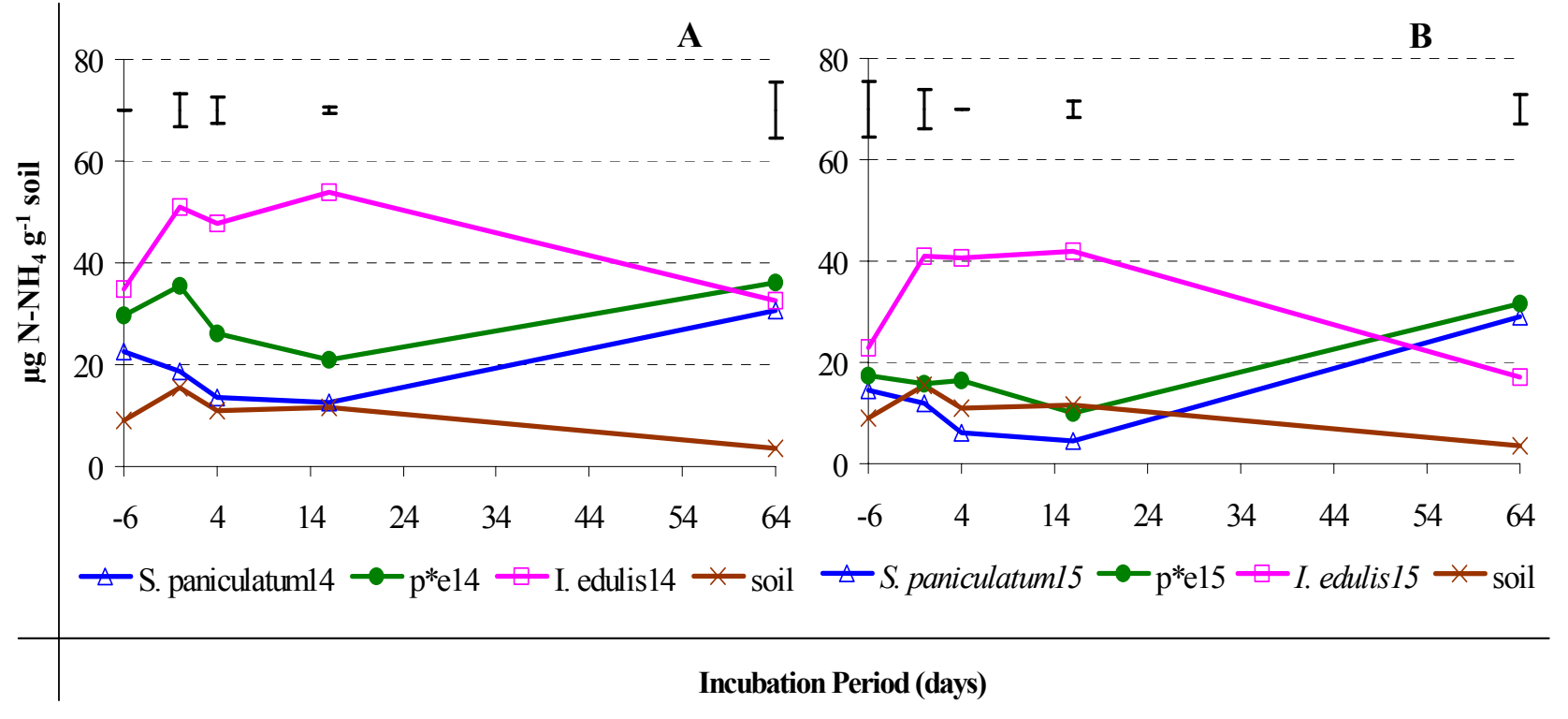

Figure 11. (A) Total N-mineralization $\left(\mu \mathrm{g} \mathrm{NH}_{4}{ }^{+}-\mathrm{N} \mathrm{g}^{-1}\right.$ soil) during the laboratory incubation (days) for samples with ${ }^{14} \mathrm{~N}$ leaf material and fertilized with enriched ${ }^{15} \mathrm{~N}$-urea $\left({ }^{14}\right.$ after species name), and (B) samples with ${ }^{15} \mathrm{~N}$ enriched leaf material and fertilized with ${ }^{14} \mathrm{~N}$-urea $\left({ }^{15}\right.$ after species name). Soil control was soil without added leaf material and fertilized with ${ }^{14} \mathrm{~N}$-urea. The bars represent LSD $\mathrm{P}<0.05$.

The different amounts of added leaf material (Table 12) resulted in different $\mathrm{NH}_{4}{ }^{+}-\mathrm{N}$ concentrations (Figure $11 \mathrm{~A}$ and B). In general, less leaf material showed a higher N mineralization. At the end of the incubation period, I. edulis and the control showed a greater decrease in the $\mathrm{NH}_{4}{ }^{+}-\mathrm{N}$ concentrations in the two experiments (Figure $11 \mathrm{~A}$ and B). In contrast, the mixture and $S$. paniculatum showed a significant $(\mathrm{P}<0.01)$ increase in $\mathrm{NH}_{4}{ }^{+}-\mathrm{N}$.

The I. edulis and S. paniculatum treatments showed the same N-mineralization pattern compared with the previous experiment (3.1.2.2). However, when no woody material was used and N-urea was added, N-mineralization was significantly higher (Figure 3 and 11). Soil without added organic matter in the control showed a significantly higher initial $\mathrm{NH}_{4}{ }^{+}-\mathrm{N}$ concentration when urea-N was applied, a difference not observed at the end of the incubation period (Figure 3 and 11).

\subsubsection{Microbial biomass nitrogen in soil}

The nitrogen immobilization pattern showed marked differences between the two experiments (Figure $12 \mathrm{~A}$ and B) but did not explain the differences in N-mineralization between the two experiments described above. The variability of the data was higher and the statistical 
difference $(\mathrm{P} \leq 0.05)$ was observed only for the $\mathrm{p}^{*} \mathrm{e}$ mixture and I. edulis treatments (Figure $12 \mathrm{~A})$.

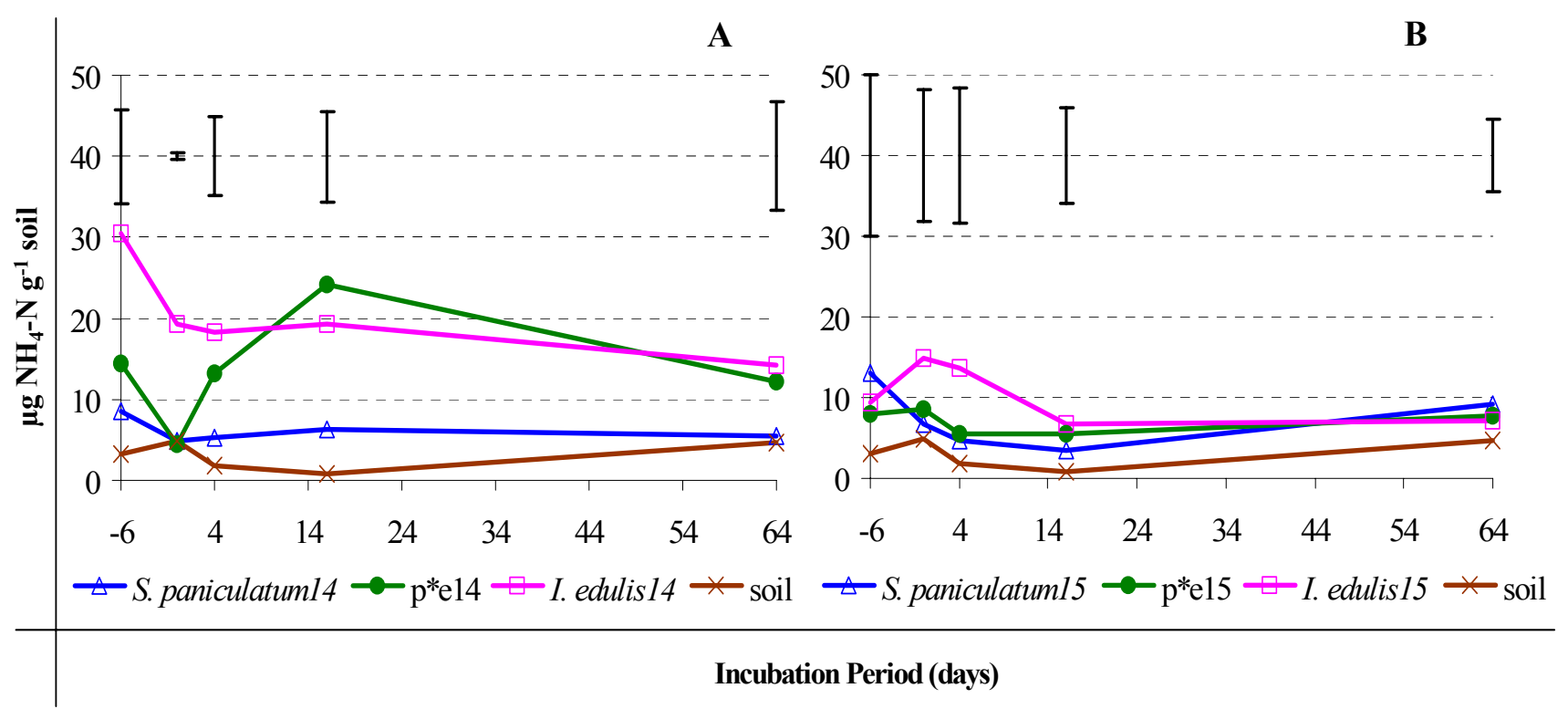

Figure 12. (A) Nitrogen microbial biomass $\left(\mu \mathrm{g} \mathrm{NH}{ }_{4}{ }^{+}-\mathrm{N} \mathrm{g}^{-1}\right.$ soil) during the laboratory incubation period (days) for samples with ${ }^{14} \mathrm{~N}$ leaf material and fertilized with enriched ${ }^{15} \mathrm{~N}$ urea ( ${ }^{14}$ after species name), (B) and samples with ${ }^{15} \mathrm{~N}$ enriched leaf material and fertilized with ${ }^{14} \mathrm{~N}$-urea ( ${ }^{15}$ after species name). Control was soil without added leaf material and fertilized with ${ }^{14} \mathrm{~N}$-urea. The bars represent $\mathrm{LSD}_{<0.05}$.

After 16 days until end of the incubation period, the S. paniculatum and $\mathrm{p}^{*}$ e mixture treatments showed a stronger growth of white fungi, especially in the S. paniculatum treatment (personal observation), whereas this fungi was not observed in the I. edulis treatment. The fumigation-extraction method used for estimating $\mathrm{N}$-immobilization was not able to determine the $\mathrm{N}$ absorbed by the fungi, and the microbial immobilization in these two treatments was probably underestimated.

Lignin is a natural polymer in the cell wall that strengthens wood, and white rot fungi, which uses cellulose as a carbon source, possesses the unique ability to degrade lignin completely to carbon dioxide to access the cellulose molecule (Aust and Benson 1993). Peroxidases and hydrogen peroxide, which are secreted by the fungi, catalyze the reactions of the highly reactive and nonspecific free radicals, resulting in the depolymerization and degradation of lignin (Myers et al. 1994).

The total amount of $\mathrm{N}$ mineralized in the legume treatments ranged from 7.91 to $22.78 \%$ of total initial added $\mathrm{N}$ (Table 14). In general, the treatments with lower concentrations of lignin 
+ phenol and a higher P concentration (Table 13) showed higher accumulative total mineralization (Table 14). The control treatment showed a higher proportional mineralization, and the accumulative mineralization.

Table 14. Proportional $\mathrm{NH}_{4}{ }^{+}-\mathrm{N}(\%)$, mineralized + immobilized, from total initial $\mathrm{N}$ added with leaf material and chemical fertilizer for different treatments during the incubation period, and total accumulative.

\begin{tabular}{|c|c|c|c|c|c|c|c|}
\hline \multirow{3}{*}{$\begin{array}{l}\text { Incubation } \\
\text { period } \\
\text { (Days) }\end{array}$} & \multicolumn{2}{|c|}{ S. paniculatum } & \multicolumn{2}{|c|}{$\mathrm{p}^{* \mathrm{e}}$} & \multicolumn{2}{|c|}{ I. edulis } & \multirow[t]{2}{*}{ Soil $^{\Phi}$} \\
\hline & 14 & 15 & 14 & 15 & 14 & 15 & \\
\hline & \multicolumn{7}{|c|}{$\%$} \\
\hline 0 & 1.36 & 1.16 & 2.24 & 1.55 & 3.22 & 3.53 & 25.3 \\
\hline 4 & 1.09 & 0.66 & 2.22 & 1.38 & 2.86 & 3.43 & 15.8 \\
\hline 16 & 1.09 & 0.50 & 2.54 & 0.99 & 3.16 & 3.08 & 15.5 \\
\hline 64 & 2.10 & 2.35 & 2.73 & 2.50 & 2.15 & 1.53 & 10.1 \\
\hline Total & 7.44 & 6.36 & 12.19 & 8.01 & 13.59 & 13.6 & 81.68 \\
\hline
\end{tabular}

${ }^{14}$ after species name means that the treatment was added leaf material (older material) with ${ }^{15} \mathrm{~N}$ at natural abundance $\left(0.366\right.$ atom $\left.\%{ }^{15} \mathrm{~N}\right)$ and was fertilized with enriched ${ }^{15} \mathrm{~N}$-urea $\left(5.320\right.$ atom $\left.\%{ }^{15} \mathrm{~N}\right)$. ${ }^{15}$ after species name means that the treatment was added previously ${ }^{15} \mathrm{~N}$-enriched leaf material (younger material) and was fertilized with ${ }^{14} \mathrm{~N}$-urea.

${ }^{\Phi}$ Soil as control was added only ${ }^{14} \mathrm{~N}$-chemical fertilization.

\subsubsection{Nitrified-N $\left(\mathrm{NO}_{3}^{-}-\mathrm{N}\right.$ concentration) in the soil}

No difference in nitrification $\left(\mathrm{NO}_{3}{ }^{-}-\mathrm{N}\right.$ concentration in soil) between treatments and experiments at the beginning of incubation period (Figures $13 \mathrm{~A}$ and B) was observed. After day 16, the I. edulis treatment with a small amount of leaf material (Figure $13 \mathrm{~A}$ ) and the control showed a strong increase in the $\mathrm{NO}_{3}{ }^{-} \mathrm{N}$ concentration, whereas the S. paniculatum treatment remained constant without statistical differences $(\mathrm{P}>0.05)$ between treatments and experiments with material of different ages. 
A

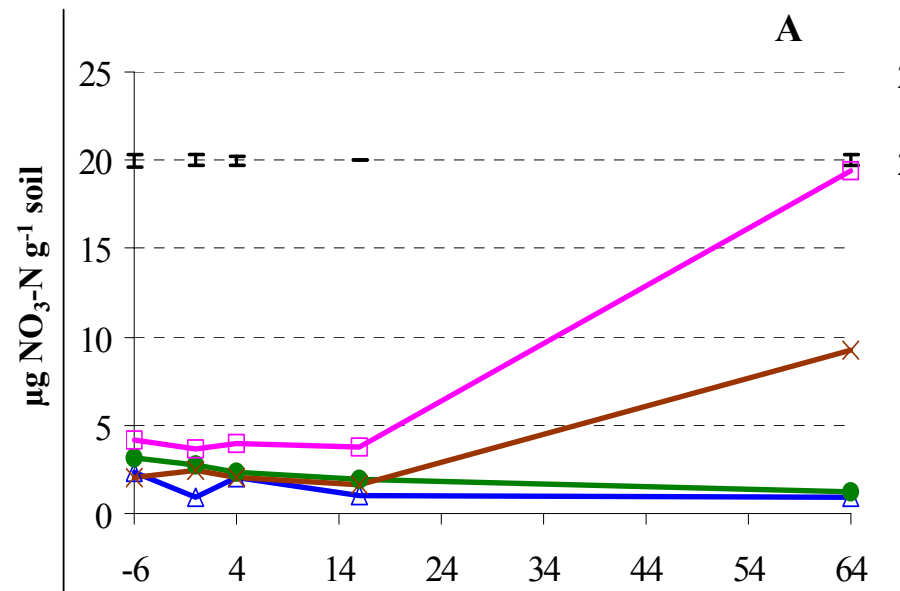

B

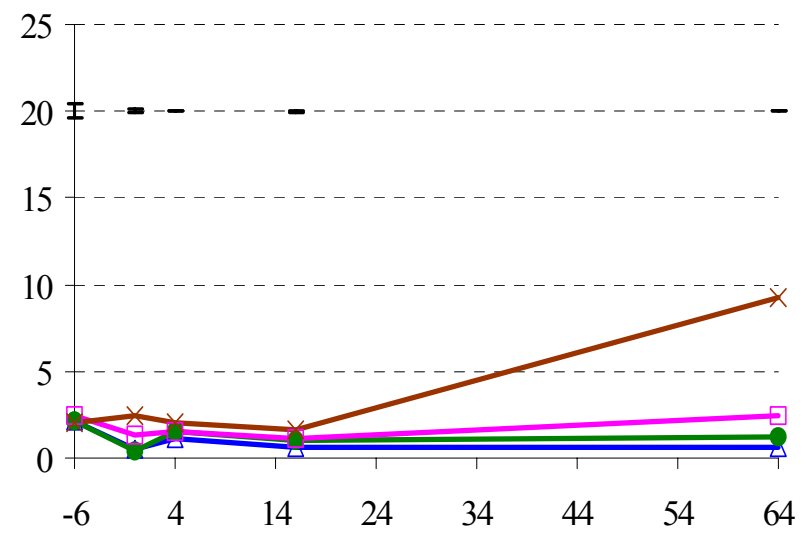

$\triangle$ S. paniculatum15 $\rightarrow$ p*e15 $\square$ I. edulis $15 *$ soil

Incubation Period (days)

Figure 13. (A) Nitrification ( $\mu \mathrm{g} \mathrm{NO}_{3}{ }^{-}-\mathrm{N} \mathrm{g}^{-1}$ soil) during the laboratory incubation period (days) for samples with ${ }^{14} \mathrm{~N}$ leaf material and fertilized with enriched ${ }^{15} \mathrm{~N}$-urea $\left({ }^{14}\right.$ after species name), and (B) samples with ${ }^{15} \mathrm{~N}$ enriched leaf material and fertilized with ${ }^{14} \mathrm{~N}$-urea $\left({ }^{15}\right.$ after species name). Control was soil without added leaf material and fertilized with ${ }^{14} \mathrm{~N}$-urea. The bars represent $\mathrm{LSD}_{<0.05}$.

\subsubsection{Nitrogen mineralization using ${ }^{14} \mathrm{~N}$-legume leaf material and enriched ${ }^{15} \mathrm{~N}$-urea fertilizers determined with diffusion procedure}

\subsubsection{Total- ${ }^{14} \mathrm{~N}$ and $-{ }^{15} \mathrm{~N}$ recovery in soil}

Total- $\left({ }^{14} \mathrm{~N}+{ }^{15} \mathrm{~N}\right)$ recovery in the soil decreased significantly $(\mathrm{P}<0.01)$ during the incubation period only in the S. paniculatum treatment (Table 15). At the end of the experiment, the $\mathrm{p}^{* \mathrm{e}}$ mixture and I. edulis treatments showed the same amounts of $\left({ }^{14} \mathrm{~N}+{ }^{15} \mathrm{~N}\right)$ compared to the values determined at the beginning of the experiment. However, the $\mathrm{p}^{*} \mathrm{e}$ mixture treatment showed a significantly higher decrease $(\mathrm{P}<0.05)$ in the total- $\left({ }^{14} \mathrm{~N}+{ }^{15} \mathrm{~N}\right)$ concentration at day 16 of the incubation period. After this, an increase was again observed. At the beginning and end of the incubation period, no statistical difference for the total soil- $\left({ }^{14} \mathrm{~N}+{ }^{15} \mathrm{~N}\right)$ concentration between treatments was observed. 
Table 15. Total- $\left({ }^{14} \mathrm{~N}+{ }^{15} \mathrm{~N}\right)\left(\mathrm{mg} \mathrm{N} \mathrm{g}{ }^{-1}\right.$ soil) concentration and ${ }^{15} \mathrm{~N}(\%)$ recovery in soil for different ${ }^{14} \mathrm{~N}$-legume treatments with ${ }^{15} \mathrm{~N}$-urea fertilizers during the incubation period (days). The ${ }^{15} \mathrm{~N}$ is expressed as the atom $\%{ }^{15} \mathrm{~N}$ excess abundance above the background $(0.3663$ atom $\%)$.

\begin{tabular}{|c|c|c|c|c|c|c|}
\hline \multirow{2}{*}{$\begin{array}{l}\text { Incubation } \\
\text { period } \\
\text { (days) }\end{array}$} & \multicolumn{2}{|c|}{ S. paniculatum } & \multicolumn{2}{|c|}{$\mathrm{p}^{*} \mathrm{e}$} & \multicolumn{2}{|c|}{ I. edulis } \\
\hline & ${ }^{14} \mathrm{~N}+{ }^{15} \mathrm{~N}$ & ${ }^{15} \mathrm{~N}$ & ${ }^{14} \mathrm{~N}+{ }^{15} \mathrm{~N}$ & ${ }^{15} \mathrm{~N}$ & ${ }^{14} \mathrm{~N}+{ }^{15} \mathrm{~N}$ & ${ }^{15} \mathrm{~N}$ \\
\hline-6 & $\Phi_{2.14^{\mathrm{a}}}$ & $\Psi_{97.0^{\alpha}}$ & $2.30^{\mathrm{a}}$ & $93.4^{\alpha}$ & $2.12^{\mathrm{a}}$ & $90.2^{\alpha}$ \\
\hline 0 & $1.63^{\mathrm{a}}$ & $81.0^{\alpha}$ & $2.02^{\mathrm{a}}$ & $87.7^{\alpha}$ & $2.04^{\mathrm{a}}$ & $57.6^{\alpha}$ \\
\hline 4 & $1.78^{\mathrm{b}}$ & $67.0^{\alpha}$ & $1.79^{\mathrm{b}}$ & $75.6^{\alpha}$ & $2.04^{\mathrm{a}}$ & $65.9^{\alpha}$ \\
\hline 16 & $1.65^{\mathrm{a}}$ & $54.2^{\beta}$ & $1.65^{\mathrm{a}}$ & $65.6^{\alpha}$ & $1.77^{\mathrm{a}}$ & $59.9^{\alpha \beta}$ \\
\hline 64 & $1.84^{\mathrm{a}}$ & $70.6^{\alpha}$ & $1.93^{\mathrm{a}}$ & $77.9^{\alpha}$ & $2.08^{\mathrm{a}}$ & $74.2^{\alpha}$ \\
\hline $\mathrm{LSD}^{\Omega}$ & $0.21^{* *}$ & $16.44^{*}$ & $0.37^{*}$ & $17.81^{*}$ & $0.35^{\mathrm{NS}}$ & $8.37^{* *}$ \\
\hline
\end{tabular}

${ }^{\Phi}$ Line with the same letter (comparing ${ }^{14} \mathrm{~N}+{ }^{15} \mathrm{~N}$ within treatment) did not show statistical differences using the Tukey test.

${ }^{\Psi}$ Symbol with the same letter (comparing ${ }^{15} \mathrm{~N}$ concentration within treatment) did not show statistical differences using the Tukey test.

${ }^{\Omega}$ LSD compares different sampling times for the same species; NS is not significant; * $=\mathrm{P}<0.05$; ** $=\mathrm{P}<0.01$.

Initial ${ }^{15} \mathrm{~N}$ recovery was the same for different treatments, but with time, recovery showed significant differences as an interaction between time and treatment (Table 15). Davidson et al (1991) showed that a low ${ }^{15} \mathrm{~N}$ recovery and its reduction during the incubation time suggest abiological ${ }^{15} \mathrm{~N}$-fixation or -volatilization. The higher significant decrease in ${ }^{15} \mathrm{~N}$ recovery was found for the S. paniculatum treatment, which showed a decrease of $44.6 \%$ in ${ }^{15} \mathrm{~N}$ recovery, followed by $I$. edulis and the $\mathrm{p}^{*} \mathrm{e}$ mixture with $31.5 \%$ and $16.1 \%$ decrease in ${ }^{15} \mathrm{~N}$ recovery, respectively. The higher ${ }^{15} \mathrm{~N}$ recovery was found in the $\mathrm{p}^{*} \mathrm{e}$ mixture treatment initially (day 0 ), but at the end of the experiment the data did not exhibit a statistical difference $(\mathrm{P}>0.05$, Tukey test) between treatments (Table 15 ). The increase in ${ }^{15} \mathrm{~N}$ recovery at the end of the experiment may be resulting from an increase in the remineralization.

Shen et al. (1984) and Davidson et al. (1991) considered the $\mathrm{NH}_{4}{ }^{+}-{ }^{15} \mathrm{~N}$ not recovered in the exchangeable pool to be instantaneously and irreversibly fixed by clay minerals and excluded from the mineralization-immobilization turnover. Losses probably occurred through denitrification, as clay fixation was probably negligible due to low clay content (sand content was $81.3 \%$ in this soil), and leaching was prevented. Losses of unlabelled $\mathrm{N}$ were probably 
much smaller than those of labeled $\mathrm{N}$ because unlabelled $\mathrm{N}$ was formed gradually throughout the experimental period, whereas labeled $\mathrm{N}$ was susceptible to losses from the beginning of the experiment.

\subsubsection{Gross $\mathbf{N}$ mineralization, nitrification, and consumption}

There are a number of assumptions that must be considered and met when using pool dilution approaches to measure $\mathrm{N}$-mineralization and immobilization. The most serious is that $\mathrm{NH}_{4}{ }^{+}-$ ${ }^{15} \mathrm{~N}$ pool dilution does not really measure mineralization and immobilization; they measure only the production and consumption of $\mathrm{NH}_{4}{ }^{+}$(Schimel 1996). The comparative immobilization results shown in this section assumed that volatilization and other process that were not measured were the same for each treatment.

The evolution of inorganic ${ }^{15} \mathrm{~N}$ in both treatments of incorporated ${ }^{14} \mathrm{~N}$-leaf legume material and applied ${ }^{15} \mathrm{~N}$-urea fertilizer is presented in Table 16. All treatments showed a significantly higher $(\mathrm{P}<0.001)$ initial gross $\mathrm{N}$-mineralization rate with a posterior decrease in the gross $\mathrm{N}$ mineralization rate during the course of the incubation period. But the decrease in mineralization for $S$. paniculatum between day 4 and day 16 was not significant $(\mathrm{P}>0.05)$. Negative values showed for nitrification and consumption come from the use of Urea as source of ${ }^{15} \mathrm{~N}$, which need firstly mineralized, and the higher decrease in nitrification during the incubation time for all treatment (Table 16).

A significantly higher $(\mathrm{P}<0.001)$ initial gross mineralization was found in the $I$. edulis treatment, followed by the $\mathrm{p}^{*} \mathrm{e}$ mixture and S. paniculatum treatments. At the same time, nitrification $(\mathrm{P}<0.01)$ was lower and $\mathrm{NO}_{3}{ }^{-}$consumption $(\mathrm{P}<0.01)$ was higher in the $S$. paniculatum treatment.

After 16 days of soil incubation, S. paniculatum showed higher significant gross Nmineralization, gross $\mathrm{NH}_{4}{ }^{+}$-consumption, and $\mathrm{NO}_{3}{ }^{-}{ }^{-15} \mathrm{~N}$ consumption rate in comparison with the I. edulis treatment. During the same period, the $\mathrm{p}^{*}$ e mixture was significantly slower in gross $\mathrm{N}$-mineralization, $\mathrm{NH}_{4}{ }^{+}$-consumption and nitrification, and intermediate in $\mathrm{NO}_{3}{ }^{-}$ consumption. 
Table 16. Gross rates of $\mathrm{N}$ mineralization, consumption, and nitrification $\left(\mu \mathrm{g} \mathrm{N} \mathrm{g}^{-1}\right.$ soil day $\left.{ }^{-1}\right)$ in soil with different legume leaf amendments determined through ${ }^{15} \mathrm{~N}$ isotopic pool dilution (Equation 6 and 7).

\begin{tabular}{|c|c|c|c|c|c|}
\hline \multirow[t]{2}{*}{ Treatment } & $\begin{array}{c}\text { Incubation } \\
\text { period } \\
\text { (days) }\end{array}$ & $\begin{array}{c}\mathrm{NH}_{4}{ }^{+}-\mathrm{N} \\
\text { mineralization } \\
\text { (m) }\end{array}$ & $\begin{array}{c}\mathrm{NH}_{4}{ }^{+}-\mathrm{N} \\
\text { consumption }\end{array}$ & $\begin{array}{c}\mathrm{NO}_{3}{ }^{-}-\mathrm{N} \\
\text { nitrification } \\
\text { (n) }\end{array}$ & $\begin{array}{c}\mathrm{NO}_{3}{ }^{-}-\mathrm{N} \\
\text { consumption }\end{array}$ \\
\hline & & \multicolumn{4}{|c|}{$\mu \mathrm{g} \mathrm{N} \mathrm{g}^{-1}$ soil day ${ }^{-1}$} \\
\hline \multirow[t]{3}{*}{ S. paniculatum } & 4 & $0.98^{\mathrm{c}}$ & $1.06^{\mathrm{b}}$ & $0.024^{\mathrm{b}}$ & $0.18^{\mathrm{a}}$ \\
\hline & 16 & $0.98^{\mathrm{a}}$ & $1.27^{\mathrm{a}}$ & $0.014^{\mathrm{b}}$ & $0.07^{\mathrm{a}}$ \\
\hline & 64 & $0.20^{\mathrm{b}}$ & $0.20^{\mathrm{a}}$ & $0.003^{b}$ & $0.02^{\mathrm{a}}$ \\
\hline LSD & & $0.001^{* * *}$ & $0.206^{*}$ & $0.021^{*}$ & $0.041^{* *}$ \\
\hline \multirow[t]{3}{*}{$\mathrm{p}^{*} \mathrm{e}$} & 4 & $2.51^{b}$ & $2.86^{\mathrm{a}}$ & $0.14^{\mathrm{b}}$ & $-0.01^{b}$ \\
\hline & 16 & $0.40^{\mathrm{c}}$ & $0.44^{\mathrm{c}}$ & $0.01^{\mathrm{b}}$ & $0.03^{b}$ \\
\hline & 64 & $0.22^{\mathrm{a}}$ & $0.16^{\mathrm{b}}$ & $-0.001^{b}$ & $0.02^{\mathrm{a}}$ \\
\hline LSD & & $0.034^{* * *}$ & $0.069^{* * *}$ & $0.013^{* *}$ & $0.039^{\mathrm{NS}}$ \\
\hline \multirow[t]{3}{*}{ I. edulis } & 4 & $3.53^{\mathrm{a}}$ & $3.58^{\mathrm{a}}$ & $0.36^{\mathrm{a}}$ & $-0.006^{b}$ \\
\hline & 16 & $0.83^{\mathrm{b}}$ & $0.74^{\mathrm{b}}$ & $0.14^{\mathrm{a}}$ & $-0.003^{b}$ \\
\hline & 64 & $0.13^{\mathrm{c}}$ & $0.14^{\mathrm{b}}$ & $0.08^{\mathrm{a}}$ & $-0.030^{b}$ \\
\hline LSD & & $0.026^{* * *}$ & $0.056^{* * *}$ & $0.062^{* *}$ & $0.027^{\mathrm{NS}}$ \\
\hline
\end{tabular}

${ }^{¥}$ Values within a column for the same time that are followed by different letters are significantly different with the Tukey test $(\mathrm{P}<0.05)$. LSD compares the differences between time for the same treatment; NS is not significant; $*=\mathrm{P}<0.05 ; * *=\mathrm{P}<0.01 ; * * *=\mathrm{P}<0.001$.

At the end of the incubation period, N-mineralization rates were significantly higher $(\mathrm{P}<$ 0.01 ) for the $\mathrm{p}^{*} \mathrm{e}$ mixture treatment when compared with the intermediate values for the $S$. paniculatum treatment and the lower values for the I. edulis treatment. The high $\mathrm{NO}_{3}{ }_{-}^{-15} \mathrm{~N}$ nitrification and low $\mathrm{NO}_{3}{ }_{-}^{-15} \mathrm{~N}$ consumption for the I. edulis treatment are due to the higher $\mathrm{NO}_{3}{ }^{-}\left({ }^{14} \mathrm{~N}+{ }^{15} \mathrm{~N}\right)$ concentration (Figure $13 \mathrm{~A}$ ). The higher $\mathrm{NO}_{3}{ }^{-} \mathrm{N}$ concentration is probably the result of the mineralization of the $I$. edulis leaf-material with subsequent nitrification, which diluted the $\mathrm{NO}_{3}{ }_{-}^{-15} \mathrm{~N}$ that came from the urea fertilizer.

Estimation of gross $\mathrm{NH}_{4}{ }^{+}$-immobilization is shown in Table 17. The calculation was made with the gross $\mathrm{NH}_{4}{ }^{+}$-consumption minus the sum of $\mathrm{NO}_{3}{ }^{-}-\mathrm{N}$ nitrification $(n)$ and $\mathrm{NO}_{3}{ }^{-}-\mathrm{N}$ 
consumption (adapted from Davidson et al. 1991) as shown in Table 16. It assumes the premises above mentioned.

Table 17. Estimation of gross $\mathrm{NH}_{4}{ }^{+}$-immobilization $\left(\mu \mathrm{g} \mathrm{N} \mathrm{g}^{-1}\right.$ soil day $\left.{ }^{-1}\right)$ in soil with different legume leaf amendments determined through ${ }^{15} \mathrm{~N}$ isotopic pool dilution.

\begin{tabular}{|c|c|c|c|c|}
\hline \multirow{3}{*}{$\begin{array}{l}\text { Treatment/ } \\
\text { Time (days) }\end{array}$} & \multicolumn{3}{|c|}{ Immobilization ${ }^{¥}$} & \\
\hline & \multicolumn{4}{|c|}{$\mu \mathrm{g} \mathrm{N} \mathrm{g}^{-1}$ soil day ${ }^{-1}$} \\
\hline & 4 & 16 & 64 & $\mathrm{LSD}_{<0.05}$ \\
\hline S. paniculatum & $0.86^{\mathrm{b}}$ & $1.19^{\mathrm{a}}$ & $0.17^{\mathrm{a}}$ & $0.33^{* *}$ \\
\hline $\mathrm{p}^{*} \mathrm{e}$ & $2.73^{\mathrm{a}}$ & $0.39^{c}$ & $0.14^{\mathrm{a}}$ & $0.01^{* * *}$ \\
\hline I. edulis & $3.23^{\mathrm{a}}$ & $0.60^{\mathrm{b}}$ & $0.10^{\mathrm{b}}$ & $0.02^{* * *}$ \\
\hline
\end{tabular}

${ }^{¥}$ Values within a column for the same time that are followed by different letters are significantly different with the Tukey test $(\mathrm{P}<0.05)$. LSD compares the differences between time for the same treatment; NS is not significant; $*=\mathrm{P}<0.05 ; * *=\mathrm{P}<0.01 ; * * *=\mathrm{P}<0.001$.

All treatments showed a significant decrease in $\mathrm{N}$-immobilization during the incubation time (Table 17). A significantly higher initial immobilization was evident for the I. edulis and $\mathrm{p}^{*} \mathrm{e}$ mixture treatments in comparison with $S$. paniculatum treatment. After 16 days of incubation time, only the $S$. paniculatum treatment showed an increase in immobilization rate and exceeded those of the other treatments. In the same time, the $\mathrm{p}^{*} \mathrm{e}$ mixture treatment showed a significantly lower $\mathrm{N}$-immobilization in comparison with the two single species. At the end of the experiment, the I. edulis treatment showed a significantly lower $(\mathrm{P}<0.05) \mathrm{N}$ immobilization in comparison with the other two treatments, which did not differ. The data presented in this table show that the effect of urea addition varies highly with the different amendments of organic matter.

\subsubsection{Microbial biomass $-{ }^{15} \mathrm{~N}$}

The lowest gross $\mathrm{NH}_{4}{ }^{+}-\mathrm{N}$ consumption ( $c$, Table 16) and $\mathrm{N}$-immobilization (Table 17) for the mixture treatment after 16 days of incubation was confirmed by the lower microbial biomass${ }^{15} \mathrm{~N}$ (Figure 14) measured by the fumigation extraction method. A higher initial gross Nmineralization rate (Table 16) led to a significantly higher $(\mathrm{P}<0.01) \mathrm{N}$-immobilization by soil microbial biomass (Figure 14). However, at the end of the experiment, the significantly higher gross $\mathrm{N}$-mineralization for the $\mathrm{p}^{*} \mathrm{e}$ mixture resulted in a significantly lower ${ }^{15} \mathrm{~N}$ microbial biomass. It is, however, important to remember that the fumigation extraction probably underestimated the total microbial immobilization. Hobbie (2000) demonstrated that decomposers are strongly limited by $\mathrm{C}$ quality, and it can be assumed that the I. edulis 
treatment presented advantages in terms of C quality in comparison to the $S$. paniculatum treatment.

A

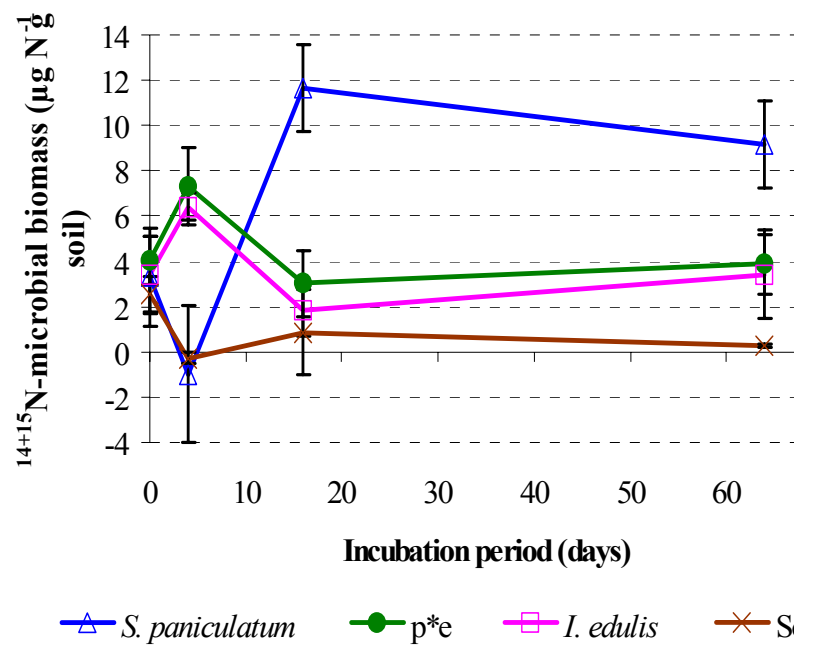

B
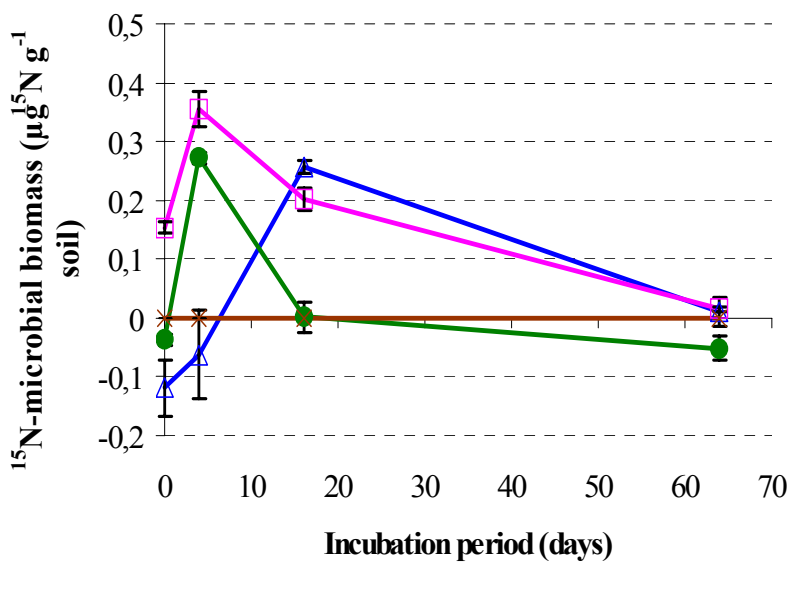

Figure 14. (A) Total $\left({ }^{14} \mathrm{~N}+{ }^{15} \mathrm{~N}\right)$-microbial biomass and (B) total ${ }^{15} \mathrm{~N}$-microbial biomass excess during the incubation period for different treatments of legume leaf material incorporated in the soil estimated by micro-diffusion analysis. The bars represent standard error of the mean. The ${ }^{15} \mathrm{~N}$ excess is expressed as the atom $\%{ }^{15} \mathrm{~N}$ excess abundance above the background $(0.3663$ atom \%).

This experiment showed that the microorganisms in the soil with the mixture treatment increased $\left({ }^{14} \mathrm{~N}+{ }^{15} \mathrm{~N}\right)$-microbial absorption at the beginning of the experiment (Figure $14 \mathrm{~A}$ and B). However, after four days of incubation, the increase in $\mathrm{N}$-absorption by microorganisms in the soil was not stimulated by the ${ }^{15} \mathrm{~N}$-urea fertilization (Figure 14). The $\mathrm{N}$ used by soil microorganisms thus appears to come principally from organic matter decomposition.

When the time interval between the labeled-N addition and the soil sampling is extended to 2 weeks, immobilized ${ }^{15} \mathrm{~N}$ may be remineralized (Bristow et al. 1987), which is often considered to lead to the underestimation of gross mineralization and immobilization rates (Davidson et al. 1991, Barraclough 1995). However, in view of the fact that remineralization is a fundamental part of the mineralization-immobilization turnover, a shortened period of study may ignore the effect of this process in the entire $\mathrm{N}$ cycle (Wang et al. 2001).

Based on these results, the $\mathrm{p}^{*} \mathrm{e}$ mixture treatment appears to be at an advantage compared with single species with the chemical fertilizer added, because it showed an initial intermediate $\mathrm{N}$-mineralization with an increase in mineralization at the end of experiment. 
Moreover, the mixture treatment decreased $\mathrm{N}$ microbial immobilization and $\mathrm{NO}_{3}{ }^{-}-\mathrm{N}$ production, thus reducing the $\mathrm{N}$ losses by leaching.

\subsubsection{Nitrogen mineralization using enriched ${ }^{15} \mathrm{~N}$-legume leaf material and ${ }^{14} \mathrm{~N}$-urea fertilizer}

In general, the total ${ }^{14} \mathrm{~N}+{ }^{15} \mathrm{~N}\left(\mathrm{mg} \mathrm{N} \mathrm{g}^{-1}\right.$ soil) and ${ }^{15} \mathrm{~N}$-excess recovered (\%) did not show statistical differences between treatments during the incubation time for the same treatments (Table 18). Only after pre-incubation did S. paniculatum significantly more ${ }^{15} \mathrm{~N}$ was recovered in comparison to the other treatments.

Table 18. Total- $\left({ }^{14} \mathrm{~N}+{ }^{15} \mathrm{~N}\right)\left(\mathrm{mg} \mathrm{N} \mathrm{g}{ }^{-1}\right.$ soil) concentration and ${ }^{15} \mathrm{~N}$ recovery in soil for different ${ }^{15} \mathrm{~N}$-legume treatment and fertilized with ${ }^{14} \mathrm{~N}$-urea during the incubation period. ${ }^{15} \mathrm{~N}$ is expressed as the atom $\%{ }^{15} \mathrm{~N}$ excess abundance above the background $(0.3663$ atom $\%)$.

\begin{tabular}{|c|c|c|c|c|c|c|}
\hline \multirow{2}{*}{$\begin{array}{l}\text { Incubation } \\
\text { period } \\
\text { (days) }\end{array}$} & \multicolumn{2}{|c|}{ S. paniculatum } & \multicolumn{2}{|c|}{$\mathrm{p}^{* \mathrm{e}}$} & \multicolumn{2}{|c|}{ I. edulis } \\
\hline & ${ }^{14} \mathrm{~N}+{ }^{15} \mathrm{~N}{ }^{\Phi}$ & ${ }^{15} \mathrm{~N}^{\Psi}$ & ${ }^{14} \mathrm{~N}+{ }^{15} \mathrm{~N}$ & ${ }^{15} \mathrm{~N}$ & ${ }^{14} \mathrm{~N}+{ }^{15} \mathrm{~N}$ & ${ }^{15} \mathrm{~N}$ \\
\hline-6 & $1.78^{\mathrm{a}}$ & $82.7^{\alpha}$ & $2.02^{\mathrm{a}}$ & $74.9^{\alpha}$ & $2.01^{\mathrm{a}}$ & $63.0^{\circ}$ \\
\hline 0 & $1.72^{\mathrm{a}}$ & $103.4^{\alpha}$ & $1.87^{\mathrm{a}}$ & $69.6^{\beta}$ & $1.85^{\mathrm{a}}$ & $71.0^{ß}$ \\
\hline 4 & $1.98^{\mathrm{a}}$ & $95.2^{\alpha}$ & $1.99^{\mathrm{a}}$ & $89.2^{\alpha}$ & $2.05^{\mathrm{a}}$ & $77.3^{\circ}$ \\
\hline 16 & $1.94^{\mathrm{a}}$ & $96.1^{\alpha}$ & $1.98^{\mathrm{a}}$ & $65.0^{\alpha}$ & $2.02^{\mathrm{a}}$ & $60.0^{\alpha}$ \\
\hline 64 & $1.87^{\mathrm{a}}$ & $95.7^{\alpha}$ & $2.14^{\mathrm{a}}$ & $72.2^{\alpha}$ & $2.11^{\mathrm{a}}$ & $68.5^{\circ}$ \\
\hline $\mathrm{LSD}^{\Omega}$ & $0.258^{\mathrm{NS}}$ & $20.70^{\mathrm{NS}}$ & $0.168^{\mathrm{NS}}$ & $16.99^{\mathrm{NS}}$ & $0.100^{*}$ & $10.58^{\mathrm{NS}}$ \\
\hline
\end{tabular}

\footnotetext{
${ }^{\Phi}$ No statistical difference in line (the same sampling time) with same letter (comparing ${ }^{14} \mathrm{~N}+{ }^{15} \mathrm{~N}$ concentration for treatment) according to Tukey test

${ }^{\Psi}$ No statistical difference in line (the same sampling time) with same symbol (comparing ${ }^{15} \mathrm{~N}$ recovery for treatment) according to Tukey test

${ }^{\Omega}$ LSD compares differences in sampling times in the same treatment; NS is not significant; $*=\mathrm{P}<$ 0.05
}

\subsubsection{Total $\mathrm{N}$ mineral $(\mathrm{N}-\mathrm{min})$ in soil}

The higher and more rapid total ${ }^{15} \mathrm{~N}$-mineralization in the $I$. edulis treatment due to added leaf material (Figure $15 \mathrm{~B}$ ) did not result in higher increases in initial N-mineralization (Figure 15 A). This suggests a greater influence from urea fertilizer or immobilization. 
A

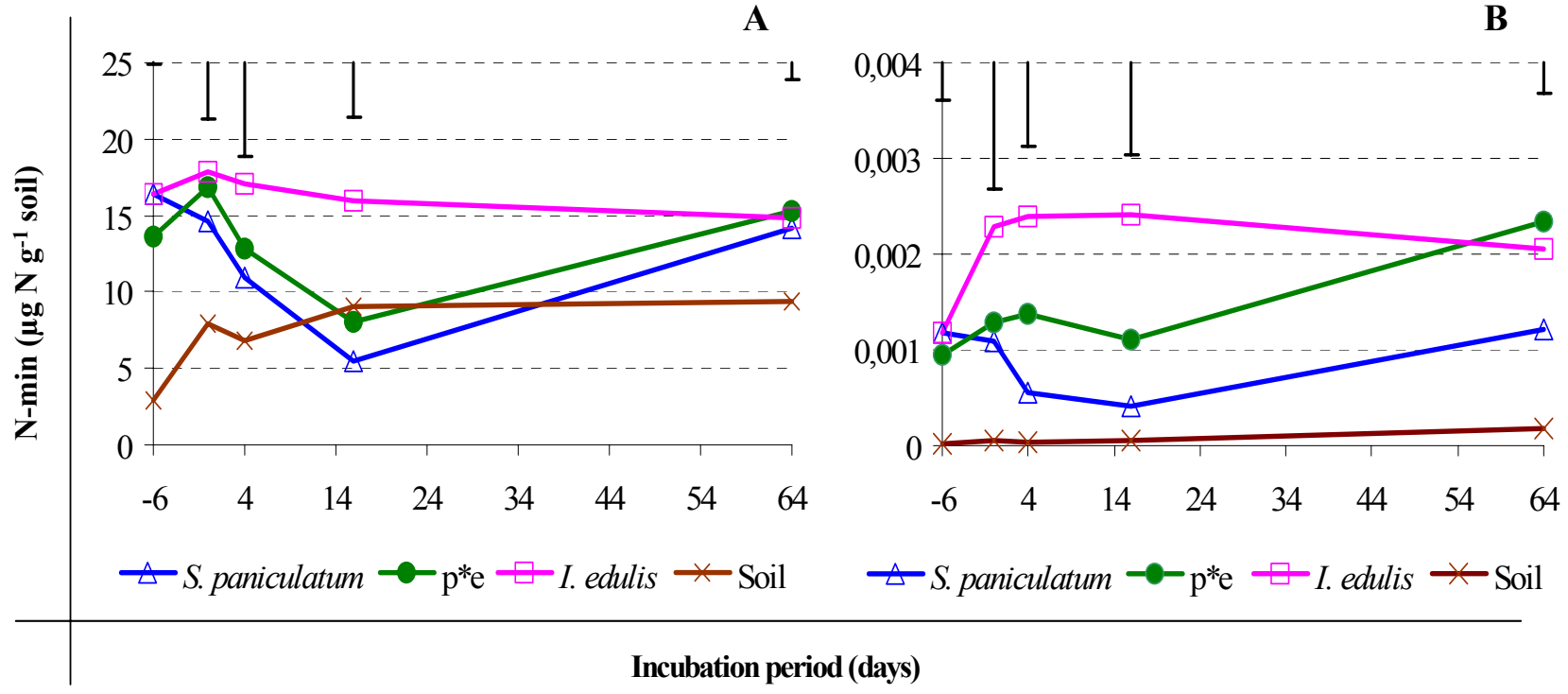

Figure 15. (A) Total $\left({ }^{14} \mathrm{~N}+{ }^{15} \mathrm{~N}\right)$-mineral and (B) total ${ }^{15} \mathrm{~N}$-mineralization during the incubation period for different treatments with legume leaf material incorporated in soil determined by micro-diffusion analysis. The bars represent $\mathrm{LSD}_{<0.05}$. The ${ }^{15} \mathrm{~N}$ is expressed as the atom $\%$ ${ }^{15} \mathrm{~N}$ excess abundance above the background (0.3663 atom \%).

The two other treatments, i.e., S. paniculatum and p*e mixture, showed a higher initial N consumption (to be commented on later). However, at the end of the incubation period, the increases in $\mathrm{N}$-mineral for the $\mathrm{p}^{*} \mathrm{e}$ mixture treatment were mainly the result of leaf decomposition, as this treatment showed a marked increase in ${ }^{15} \mathrm{~N}$-min concentration (Figure $15 \mathrm{~B})$.

The significantly higher $(\mathrm{P}<0.01)$ total ${ }^{15} \mathrm{~N}-$ min for the $\mathrm{p}^{*} \mathrm{e}$ mixture treatment in comparison to the $S$. paniculatum treatment (Figure $15 \mathrm{~B}$ ) did not represent a significantly higher $\left({ }^{14} \mathrm{~N}+{ }^{15} \mathrm{~N}\right)$-min (Figure $15 \mathrm{~A}$ ). This implies that the increase in total $\mathrm{N}$-min for the $S$. paniculatum treatment was strongly influenced by $\mathrm{N}$ from the soil or by the urea fertilizer (Table 18).

\subsubsection{Nitrogen mineralization $\left(\mathrm{NH}_{4}{ }^{+}-\mathrm{N}\right.$ concentration) in soil}

During the first 4 days of incubation time, the higher initial increase in $\mathrm{NH}_{4}{ }^{+}{ }^{15} \mathrm{~N}$ concentration with added $I$. edulis leaf material treatment, did not result in the same increase in $\mathrm{NH}_{4}^{+}-\left({ }^{14} \mathrm{~N}+{ }^{15} \mathrm{~N}\right)$ concentration in soil (Figure $16 \mathrm{~A}$ and $\mathrm{B}$ ). This suggests that the soil microorganisms in this treatment consumed soil $\mathrm{NH}_{4}{ }^{+}-\mathrm{N}$ at the same time and proportional to that mineralized from leaf material. 
A

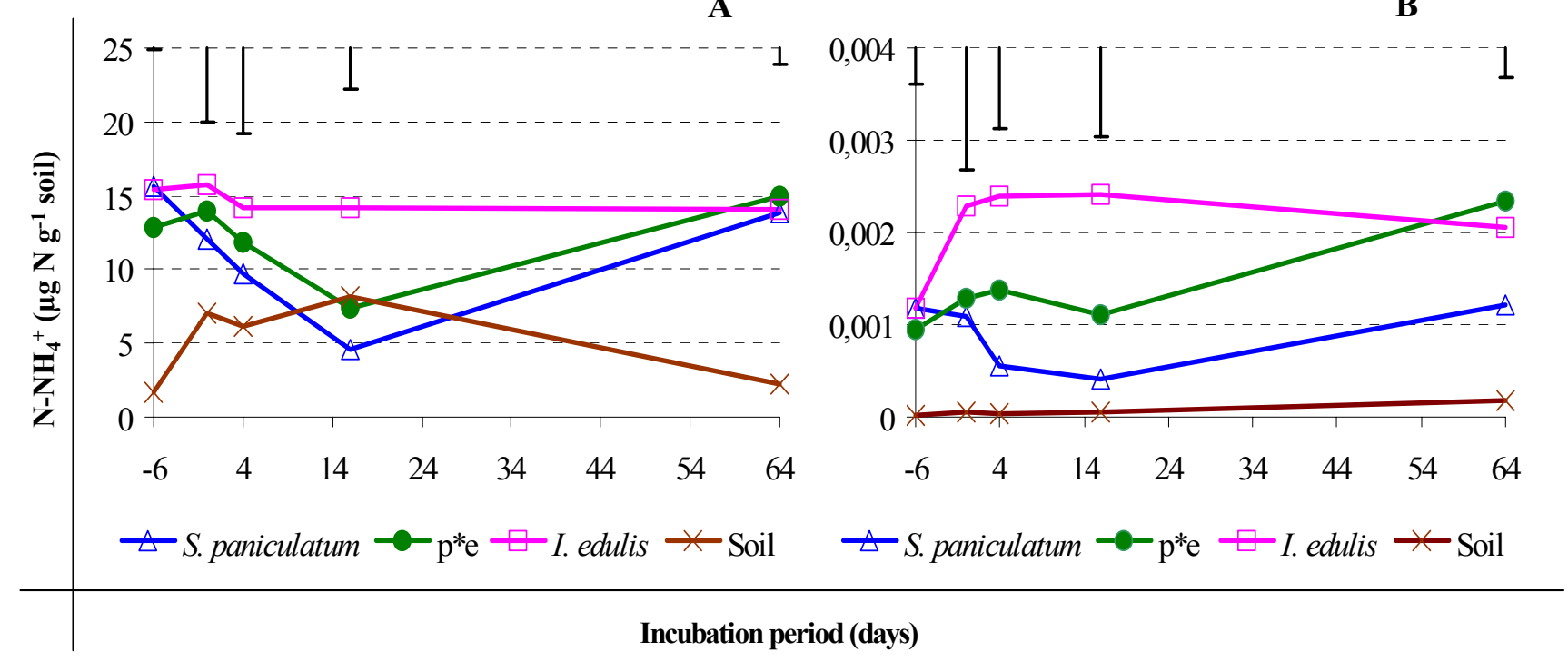

Figure 16. (A) Total $\mathrm{NH}_{4}{ }^{+}-\left({ }^{14} \mathrm{~N}+{ }^{15} \mathrm{~N}\right)$ and (B) total $\mathrm{NH}_{4}{ }^{+}-{ }^{15} \mathrm{~N}$ during the incubation period for different treatments of soil amended with legume leaf material, determined by micro-diffusion analysis. The bars represent $\mathrm{LSD}_{<0.05}$. The ${ }^{15} \mathrm{~N}$ is expressed as the atom $\%{ }^{15} \mathrm{~N}$ excess abundance above the background (0.3663 atom \%).

On the other hand, the $\mathrm{p}^{*}$ e mixture and S. paniculatum treatments appear to use more soil $\mathrm{NH}_{4}{ }^{+}-\mathrm{N}$ for decomposition of leaf material. At the end of the experiment, the increase in $\mathrm{NH}_{4}{ }^{+}-\mathrm{N}$ for the $\mathrm{p}^{*}$ e mixture and $S$. paniculatum treatments was the same (Figure $16 \mathrm{~A}$ ). However, the increase in soil $\mathrm{NH}_{4}{ }^{+}-\mathrm{N}$ resulting from leaf-material decomposition was significantly higher for the $\mathrm{p}^{*} \mathrm{e}$ mixture than for the $S$. paniculatum treatment (Figure $16 \mathrm{~B}$ ).

\subsubsection{Nitrogen immobilization}

Nitrogen immobilized by soil microorganisms was stronger with added leaf material than in the control (Figure 17). The increase in ${ }^{15} \mathrm{~N}$-microbial biomass showed that the decrease in total mineral-N in the soil in the $S$. paniculatum and $\mathrm{p}^{*} \mathrm{e}$ mixture treatments were the result of the increased $\mathrm{N}$ immobilization of the $\mathrm{N}$ that came from leaf-material decomposition. The high concentration of total $\left({ }^{14} \mathrm{~N}+{ }^{15} \mathrm{~N}\right)$-microbial biomass observed at the pre-incubation time (Figure 17) for the S. paniculatum and I. edulis treatments probably resulted from fact that the added leaf material in the soil already contained microorganisms before initiating the experiment (storage time). 
A

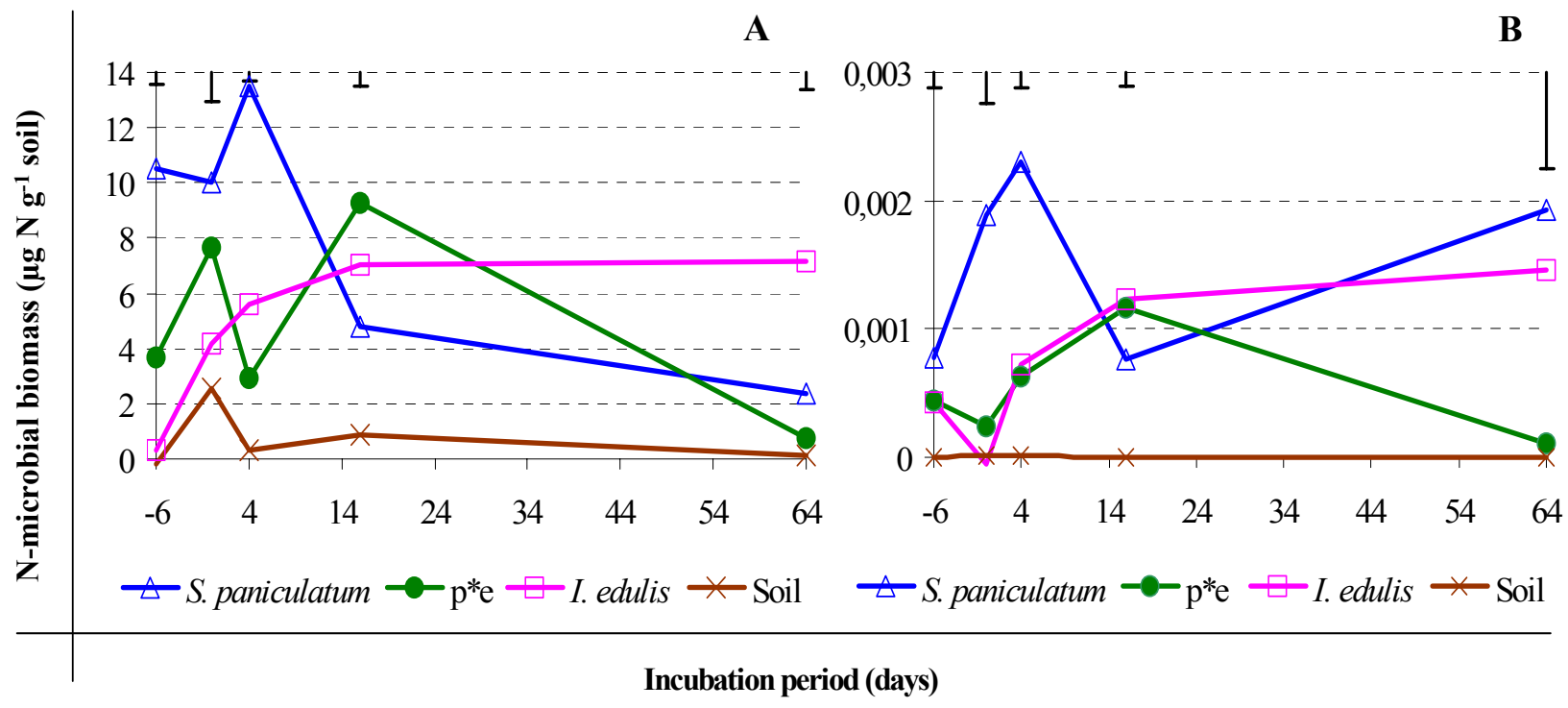

Figure 17. (A) Total $\left({ }^{14} \mathrm{~N}+{ }^{15} \mathrm{~N}\right)$-microbial biomass and (B) total ${ }^{15} \mathrm{~N}$-microbial biomass during the incubation period for different treatments with soil amended with legume leaf material determined by micro-diffusion analysis. The bars represent $\mathrm{LSD}_{<0.05}$. The ${ }^{15} \mathrm{~N}$ is expressed as the atom $\%{ }^{15} \mathrm{~N}$ excess abundance above the background ( 0.3663 atom \%).

In the same way, the increases in mineral-N and $\mathrm{NH}_{4}{ }^{+}-\mathrm{N}$ concentrations in the soil (Figure 15 A and $16 \mathrm{~A}$ ) at the end of the incubation time appear to be strongly influenced by the decreases in $\mathrm{N}$ immobilization. However, the increases in ${ }^{15} \mathrm{~N}$-microbial biomass, which need to come from leaf material, at the end of the incubation period did not represent an increase in $\left({ }^{14} \mathrm{~N}+{ }^{15} \mathrm{~N}\right)$-microbial biomass. It maybe demonstrates the strong influence of $\mathrm{N}$ in the soil (inorganic or organic) in N-microbial biomass. Apparently, the soil microorganisms first consume $\mathrm{N}$ freely available in the soil before beginning with organic matter decomposition.

\subsubsection{4 $\mathrm{N}$ nitrification $\left(\mathrm{NO}_{3}^{-}-\mathrm{N}\right.$ concentration) in soil}

The initially higher increases in $\mathrm{NO}_{3}{ }^{-}{ }^{15} \mathrm{~N}$ for the $S$. paniculatum and $\mathrm{p}^{*} \mathrm{e}$ mixture treatments, and delayed increase for the I. edulis treatment (Figure $18 \mathrm{~B}$ ) suggests that nitrification substrate comes from leaf material decomposition. The nitrification rate in the control treatment was significantly increased from day 16 onwards (Figure $18 \mathrm{~A}$ ). This suggests that the $\mathrm{NO}_{3}{ }^{-}$consumption was high in all legume treatments, but this conclusion was not supported by the ${ }^{15} \mathrm{~N}$-urea isotopic dilution experiment described above (Table 18). 
A

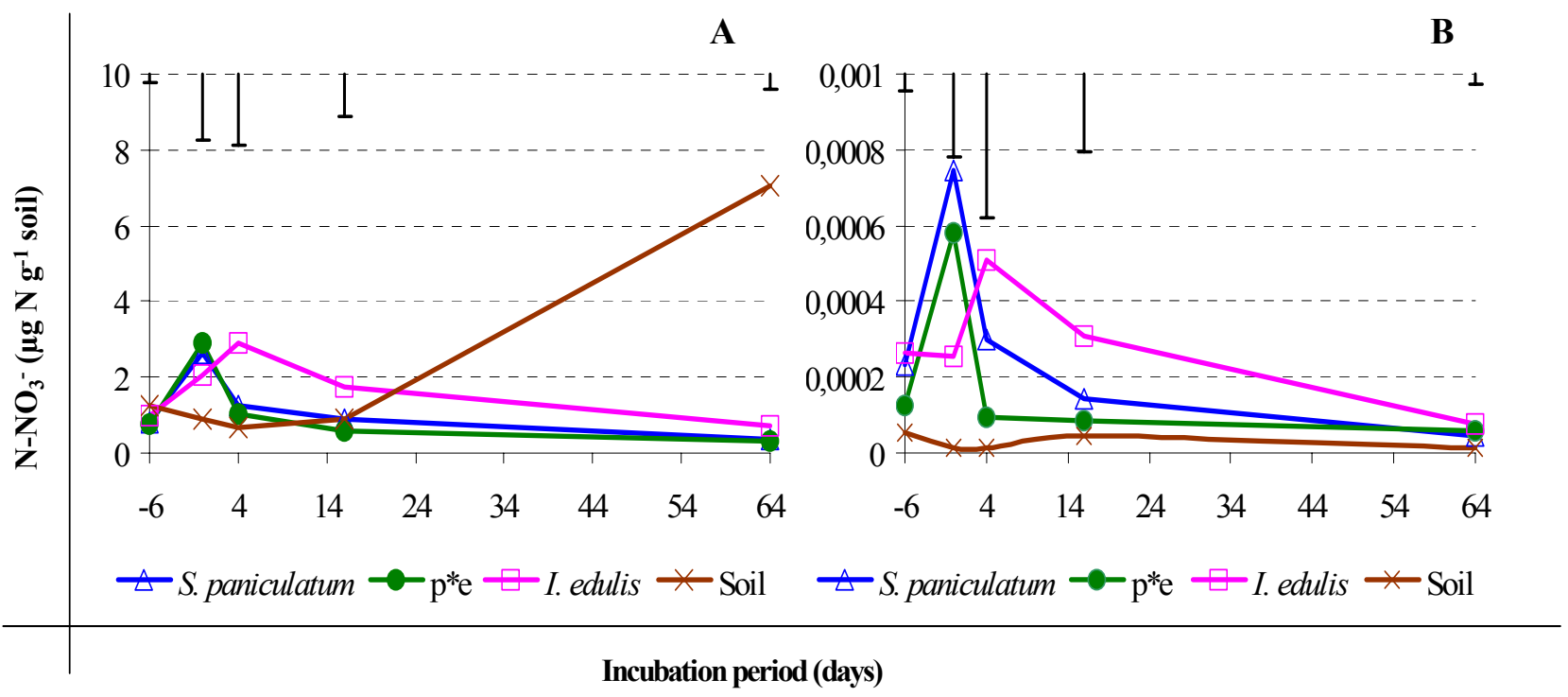

Figure 18. (A) Total $\mathrm{NO}_{3}-\left({ }^{-}{ }^{14} \mathrm{~N}+{ }^{15} \mathrm{~N}\right)$ and (B) total $\mathrm{NO}_{3}{ }^{-}{ }^{15} \mathrm{~N}$ during the incubation period for different treatments of soil amended with legume leaf material soil determined by microdiffusion analysis. The bars represent $\mathrm{LSD}_{<0.05}$. The ${ }^{15} \mathrm{~N}$ is expressed as the atom $\%{ }^{15} \mathrm{~N}$ excess abundance above the background (0.3663 atom \%).

Alternatively, it can be assumed that the high nitrification rate in the control treatment was the result of the high mineralization of unlabelled urea fertilizer. This is supported by the comparison with these results from the experiment without urea fertilizer (Figure 3). The decrease in nitrification with the single legume species and mixture treatments could also be the result of high immobilization in these two treatments.

The total initial ${ }^{15} \mathrm{~N}$-organic added in this experiment (Table 12), i.e., $1.2 \%, 1.9 \%$ and $2.7 \%$, was recovered during the incubation period as accumulated mineral- ${ }^{15} \mathrm{~N}$, , for S. paniculatum, p*e mixture and I. edulis treatments. In these treatments, $32.8 \%, 13.5 \%$ and $13.7 \%$, respectively, of the total $\mathrm{NH}_{4}{ }^{+}{ }^{15} \mathrm{~N}$ was found as $\mathrm{NO}_{3}-{ }^{-15} \mathrm{~N}$. Also, 48.5, 32.6\% and $31.5 \%$ of total N-mineral was found in the microbial biomass-N for the S. paniculatum, I. edulis and p*e mixture treatments, respectively.

In this experiment, the total mineralized $\mathrm{N}$ (N-mineral plus $\mathrm{N}$ absorbed by microorganisms) from added leaf material was $2.5 \%, 2.9 \%$, and $3.6 \%$ of the initially-added $\mathrm{N}$ for the $\mathrm{p}^{*} \mathrm{e}$ mixture, S. paniculatum, and I. edulis treatments, respectively. The $\mathrm{p}^{*} \mathrm{e}$ mixture behaved the same as I. edulis in terms of nitrification and microbial immobilization, although I. edulis showed a higher mineralization than the $\mathrm{p}^{*} \mathrm{e}$ mixture.

Differences in leaf-amended material produced great differences in soil mineral N (Table 19). Addition of leaves resulted in a higher N-mineral concentration than in the control. The use of 
minor amounts of added leaf material in the I. edulis, $\mathrm{p}^{*}$ e mixture, and S. paniculatum treatments (Table 12) showed a decrease in the accumulative soil mineral-N of $28.5 \%, 23.2 \%$, and $13.1 \%$, respectively. However, it was observed that in the case of small amounts of added leaf material, during the final phase of the incubation period (16 to 64 days), the increase in mineral-N was $47.9 \%, 19.6 \%, 8.8 \%$, and $2.2 \%$ for the S. paniculatum, $\mathrm{p}^{*}$ e mixture, I. edulis, and control treatments, respectively. Similarly, the experiment with a small amount of leaf material showed an increase in the mineral-N concentration in the order of $158.2 \%, 91.3 \%$ for the $S$. paniculatum, $\mathrm{p}^{*}$ e mixture treatments, respectively, and a decrease of $6.9 \%$ for the $I$. edulis treatment.

The overall mineral- ${ }^{15} \mathrm{~N}$ in the soil decreased in the experiment with added ${ }^{15} \mathrm{~N}$-urea in all treatments (Table 19) and increased with added ${ }^{15} \mathrm{~N}$-legume leaf material This is because the consumption of mineral-N by microorganism in the soil for microbial growth and, consequently, decomposition of organic matter results in an increase of $\mathrm{N}$ that comes from organic material. However, the ${ }^{15} \mathrm{~N}$ added with fertilizer appears not to be remineralized, and after 64 days of incubation, the urea-N loss was $63.0 \%$ of the initially added ${ }^{15} \mathrm{~N}$ for the $S$. paniculatum and $\mathrm{p}^{*} \mathrm{e}$ mixture and $60.6 \%$ for $I$. edulis treatment.

The rapid proliferation of the microbial biomass in the low C-to-N ratio treatment (Table 12) with older material created a differentiated demand for $\mathrm{N}$ at the beginning of the experiment. As much as $104.4 \%, 90.9 \%$ and $74.4 \%$ of the added ${ }^{15} \mathrm{~N}$-urea fertilizer were recovered in the S. paniculatum, $\mathrm{p}^{*} \mathrm{e}$ mixture, and I. edulis treatments, respectively, as mineral-N (Table 19). The low fertilizer recovery observed in the I. edulis treatment is explained by the higher initial ${ }^{15} \mathrm{~N}$-microbial biomass (Table 20). 
Table 19. Diffusion procedure and total N-mineral in soil with different treatments of added ${ }^{14 a n d}{ }^{15} \mathrm{~N}$-legume leaf material and fertilized with ${ }^{15}$ and ${ }^{14} \mathrm{~N}$-urea, respectively. Control was soil without organic amendment and fertilized with ${ }^{14} \mathrm{~N}$-urea. The numbers represent mean(Standard error). The ${ }^{15} \mathrm{~N}$ is expressed as the atom $\%{ }^{15} \mathrm{~N}$ excess abundance above the background (0.3663 atom \%).

\begin{tabular}{|c|c|c|c|c|}
\hline \multirow{3}{*}{$\begin{array}{l}\text { Treatment/ } \\
\text { Incubation time } \\
\text { (days) }\end{array}$} & \multicolumn{2}{|c|}{$\begin{array}{l}{ }^{14} \mathrm{~N} \text {-legume material and } \\
{ }^{15} \mathrm{~N} \text {-urea fertilizer }\end{array}$} & \multicolumn{2}{|c|}{$\begin{array}{c}{ }^{15} \mathrm{~N} \text {-legume material and }{ }^{14} \mathrm{~N} \text {-urea } \\
\text { fertilizer }\end{array}$} \\
\hline & $\mathrm{N}$ mineral & ${ }^{15} \mathrm{~N}$ & $\mathrm{~N}$ mineral & ${ }^{15} \mathrm{~N}$ \\
\hline & \multicolumn{2}{|c|}{$\left(\mu \mathrm{g} \mathrm{N} \mathrm{g}^{-1}\right.$ soil $)$} & \multicolumn{2}{|c|}{$\left(\mu \mathrm{g} \mathrm{N} \mathrm{g}^{-1}\right.$ soil $)$} \\
\hline \multicolumn{5}{|l|}{ S. paniculatum } \\
\hline 0 & $14.9(0.40)$ & 3.1(0.06) & 14.6(1.07) & $\mathbf{0 . 0 0 1 8}(0.0005)$ \\
\hline 4 & $13.9(0.75)$ & $2.2(0.05)$ & 11.0(3.12) & $\mathbf{0 . 0 0 0 9}(0.0002)$ \\
\hline 16 & 9.4(0.30) & $\mathbf{0 . 9}(0.03)$ & $\mathbf{5 . 5}(0.98)$ & $\mathbf{0 . 0 0 0 6}(0.0001)$ \\
\hline 64 & 13.9 $(0.33)$ & $\mathbf{1 . 1}(0.02)$ & 14.2(0.30) & $\mathbf{0 . 0 0 1 3}(0.0002)$ \\
\hline \multicolumn{5}{|l|}{$\mathrm{p}^{*} \mathrm{e}$} \\
\hline 0 & 17.0 $(0.34)$ & 2.7(0.04) & $16.8(0.98)$ & $\boldsymbol{0 . 0 0 1 9}(0.0003)$ \\
\hline 4 & $16.2(0.51)$ & $1.7(0.03)$ & $12.9(0.46)$ & $\boldsymbol{0 . 0 0 1 5}(0.0002)$ \\
\hline 16 & $16.3(0.44)$ & $\mathbf{1 . 8}(0.02)$ & $\mathbf{8 . 0}(1.63)$ & $\mathbf{0 . 0 0 1 2}(0.0003)$ \\
\hline 64 & $\mathbf{1 9 . 5}(0.59)$ & $\mathbf{1 . 1}(0.01)$ & $\mathbf{1 5 . 3}(0.30)$ & $\mathbf{0 . 0 0 2 4}(0.0001)$ \\
\hline \multicolumn{5}{|l|}{ I. edulis } \\
\hline 0 & 20.2(0.19) & $2.2(0.05)$ & $\mathbf{1 7 . 8}(0.95)$ & $\mathbf{0 . 0 0 2 5}(0.0001)$ \\
\hline 4 & 21.5(0.47) & $\mathbf{1 . 3}(0.01)$ & 17.1(1.15) & $\mathbf{0 . 0 0 2 9}(0.0003)$ \\
\hline 16 & 24.0(1.05) & $\mathbf{1 . 4}(0.02)$ & $\mathbf{1 5 . 9}(1.02)$ & $\mathbf{0 . 0 0 2 7}(0.0003)$ \\
\hline 64 & 26.1(0.74) & $1.8(0.01)$ & 14.8 $(0.81)$ & $\mathbf{0 . 0 0 2 1}(0.0001)$ \\
\hline \multicolumn{5}{|l|}{ Control } \\
\hline 0 & $7.9(0.15)$ & & & \\
\hline 4 & $6.8(0.33)$ & & & \\
\hline 16 & 9.1(0.39) & & & \\
\hline 64 & 9.3(0.34) & & & \\
\hline
\end{tabular}


All legume treatments in comparison with the control showed a rapid increase in microbialbiomass-N, which was the result of the added leaf material. The soil-microbial biomass $\mathrm{N}$ increase was $60 \%, 36 \%$ and $32 \%$ after $\mathrm{p}^{*}$ e mixture, I. edulis, and S. paniculatum leaf material incorporation, respectively, with lower amounts compared to the unamended control soil after 6 days (at day 0) of leaf material incorporation (pre-incubation period). On the other hand, the higher amount of added leaf material (Table 12) led to an increase of $208 \%, 68 \%$, and $300 \%$ for $\mathrm{p}^{*} \mathrm{e}$ mixture, I. edulis, and S. paniculatum, respectively.

In all legume treatments, the microbial biomass- $\mathrm{N}$ remained significantly higher than in the control during the complete incubation period. The different dynamics of the microbialbiomass $\mathrm{N}$ in the contrasting residue treatments may be due to differences in $\mathrm{N}$ availability. In addition, microbial-biomass $\mathrm{N}$ depends on the quality of the leaf material in terms of C-to-N ratio, lignin, phenol, and $\mathrm{P}$ content, but possibly also to the introduction of different microbial populations.

The analyses of the microbial immobilization in the legume treatments led to the assumption that the greater part of the nitrogen immobilization resulted from the added organic matter. This supposition comes from the fact that the higher ${ }^{15} \mathrm{~N}$ atom $\%$ excess added at the beginning of the experiment in the form of ${ }^{15} \mathrm{~N}$-urea (Table 12) was not traceable in the microbial biomass through the fumigation-extraction procedure and diffusion method (Table 20). 
Table $20 .{ }^{15} \mathrm{~N}$ (diffusion procedure) and total microbial biomass- $\mathrm{N}$ in soil with different treatments of added ${ }^{14} \mathrm{~N}$ - and ${ }^{15} \mathrm{~N}$-legume leaf material and fertilized with ${ }^{15}$ and ${ }^{14} \mathrm{~N}$-urea, respectively. Control was soil without added organic matter and fertilized with ${ }^{14} \mathrm{~N}$-urea. The numbers represent mean (Standard error of the mean). The ${ }^{15} \mathrm{~N}$ is expressed as the atom $\%$ ${ }^{15} \mathrm{~N}$ excess abundance above the background (0.3663 atom \%).

\begin{tabular}{|c|c|c|c|c|}
\hline \multirow[b]{2}{*}{$\begin{array}{l}\text { Treatment/ } \\
\text { Incubation time }\end{array}$} & \multicolumn{2}{|c|}{$\begin{array}{c}{ }^{14} \mathrm{~N} \text {-legume material and }{ }^{15} \mathrm{~N}- \\
\text { urea }\end{array}$} & \multicolumn{2}{|c|}{$\begin{array}{c}{ }^{15} \mathrm{~N} \text {-legume material and }{ }^{14} \mathrm{~N}- \\
\text { urea }\end{array}$} \\
\hline & $\begin{array}{c}\mathrm{N} \text { microbial } \\
\text { biomass }\end{array}$ & ${ }^{15} \mathrm{~N}$ & $\begin{array}{c}\mathrm{N} \text { microbial } \\
\text { biomass }\end{array}$ & ${ }^{15} \mathrm{~N}$ \\
\hline (days) & \multicolumn{4}{|c|}{$\mu \mathrm{g} \mathrm{N} \mathrm{g}^{-1}$ soil } \\
\hline \multicolumn{5}{|l|}{ S. paniculatum } \\
\hline 0 & $\mathbf{3 . 3}(2.19)$ & $\mathbf{- 0 . 1 5}(0.05)$ & $\mathbf{1 0 . 0}(0.95)$ & $\mathbf{0 . 0 0 1 9}(0.0009)$ \\
\hline 4 & $\mathbf{2 . 1}(2.03)$ & $-\mathbf{0 . 0 1}(0.08)$ & $\mathbf{1 3 . 5}(1.15)$ & $0.0024(0.0000)$ \\
\hline 16 & 11.6(1.92) & $0.26(0.01)$ & $4.8(1.02)$ & $0.0008(0.0004)$ \\
\hline 64 & $\mathbf{9 . 1}(1.93)$ & $\mathbf{0 . 0 1}(0.02)$ & $\mathbf{2 . 3}(0.81)$ & $\mathbf{0 . 0 0 1 9}(0.0005)$ \\
\hline \multicolumn{5}{|l|}{$\overline{\mathrm{p}^{* \mathrm{e}}}$} \\
\hline 0 & 4.0(1.08) & $\mathbf{- 0 . 0 4}(0.01)$ & $7.7(1.14)$ & $0.0002(0.0010)$ \\
\hline 4 & $7.3(1.73)$ & $0.27(0.01)$ & $3.0(0.46)$ & $0.0007(0.0010)$ \\
\hline 16 & $4.8(1.47)$ & $\mathbf{0 . 0 0}(0.02)$ & $\mathbf{9 . 3}(1.63)$ & $0.0012(0.0006)$ \\
\hline 64 & 3.9(1.34) & $\mathbf{- 0 . 0 5}(0.02)$ & $\mathbf{0 . 7}(0.29)$ & $0.0001(0.0003)$ \\
\hline \multicolumn{5}{|l|}{ I. edulis } \\
\hline 0 & 3.4(0.59) & $\mathbf{0 . 1 5}(0.01)$ & 4.2(1.07) & $\mathbf{0 . 0 0 0 1}(0.0007)$ \\
\hline 4 & $6.4(1.10)$ & $\mathbf{0 . 3 6}(0.03)$ & 5.6(3.12) & $\mathbf{0 . 0 0 0 7}(0.0002)$ \\
\hline 16 & $4.2(0.53)$ & $\mathbf{0 . 2 0}(0.02)$ & $7.0(0.98)$ & $\mathbf{0 . 0 0 1 2}(0.0004)$ \\
\hline 64 & $\mathbf{3 . 4}(1.19)$ & $\mathbf{0 . 0 2}(0.01)$ & $7.2(0.30)$ & $\mathbf{0 . 0 0 1 5}(0.0006)$ \\
\hline \multicolumn{5}{|l|}{ Control } \\
\hline 0 & $\mathbf{2 . 5}(0.78)$ & & & \\
\hline 4 & $0.1(0.02)$ & & & \\
\hline 16 & $2.6(1.45)$ & & & \\
\hline 64 & $\mathbf{0 . 3}(0.08)$ & & & \\
\hline
\end{tabular}


It is difficult to experimentally prove the direct hypothesis for microbial assimilation of lowmolecular soluble organic $\mathrm{N}$, since it is difficult to trace inorganic ${ }^{15} \mathrm{~N}$-labeled $\mathrm{N}$ derived from mineralization in a soil that has been amended with an organic substrate. Mary et al. (1998) suggested that the role of direct assimilation of low-molecular organic $\mathrm{N}$ compounds from crop residues by the microbial biomass could be evaluated by comparing the mean ${ }^{15} \mathrm{~N}$ abundance of the soil inorganic- $\mathrm{N}$ and the newly formed biomass $\mathrm{N}$ pools. The size of the biomass N pool was $100 \%$ higher for the $S$. paniculatum treatment, $44.4 \%$ lower for the $\mathrm{p}^{*} \mathrm{e}$

mixture, and $36.4 \%$ lower for I. edulis treatment than that found in soil mineral ${ }^{15} \mathrm{~N}$ pool. This suggests that the residue-derived $\mathrm{N}$ was assimilated by the soil-microbial biomass without entering the soil-inorganic $\mathrm{N}$ pool depending on the organic material quality.

However, if the microbial biomass shows a much higher preference for ammonium than nitrate, it is likely that ammonium formed during mineralization of labeled residues is immobilized immediately before being nitrified in preference to a large pool of readily available nitrate (Jansson 1958).

The results from the two experiments indicate that litter quality as determined by the age of the residues play an important role in the decomposition process and nitrogen mineralization. For this reason, it appears that no single variable is sufficient to predict nutrient release patterns from residues in this experiment.

\subsection{Greenhouse study on leguminous leaf decomposition and $\mathbf{N}$ dynamics in soil using rice as an indicator plant}

In the same way as described above (Section 3.2), a fixed amount of $\mathrm{N}$ was added to the soil using different species with different ages resulting in different amounts of leaf material (Table 21). The $\mathrm{N}$ concentration of the older leaf material was more variable between the species, resulting in a greater variation in terms of the amount of added leaf material. 
Table 21. Initial amount of soil (g), leaf-amended material $(\mathrm{g})$ with nitrogen content $\left(\mathrm{mg} \mathrm{N} \mathrm{g}^{-1}\right.$ soil), added urea- $\mathrm{N}$ (mg N g ${ }^{-1}$ soil), and resulting ${ }^{15} \mathrm{~N}$ excess ( $\mu \mathrm{g}{ }^{15} \mathrm{~N}$ excess $\mathrm{g}^{-1}$ soil) in the soil of different legume treatments in the greenhouse incubation experiment. Control was the same soil without added organic matter and fertilized with ${ }^{14} \mathrm{~N}$-urea. The numbers represent Mean (Standard deviation) with $\mathrm{n}=12$. The ${ }^{15} \mathrm{~N}$ excess is expressed as the atom $\%{ }^{15} \mathrm{~N}$ excess abundance above the background (0.3663 atom \%).

\begin{tabular}{|c|c|c|c|c|c|}
\hline \multirow[t]{2}{*}{ Treatment } & Soil (g) & Leaf & $\begin{array}{c}\mathrm{N} \text { with leaf } \\
\text { material }\end{array}$ & $\begin{array}{c}\mathrm{N} \text { with urea } \\
\text { fertilizer }\end{array}$ & \multirow{2}{*}{$\frac{{ }^{15} \mathrm{~N} \text { excess }}{\mu \mathrm{g} \mathrm{g}^{-1} \text { soil }}$} \\
\hline & \multicolumn{2}{|c|}{$\mathrm{g}$} & \multicolumn{2}{|c|}{$\mathrm{mg} \mathrm{g}^{-1}$ soil } & \\
\hline S. paniculatum ${ }^{14}$ & $50.6(0.07)$ & $3.69(0.002)$ & $1.65(0.001)$ & $0.06(0.002)$ & $3.90(0.0012)$ \\
\hline $\mathrm{p}^{*} \mathrm{e}^{14}$ & $50.6(0.10)$ & $3.05(0.000)$ & $1.68(0.001)$ & $0.06(0.002)$ & $3.90(0.0010)$ \\
\hline I. edulis ${ }^{14}$ & $50.6(0.13)$ & $2.44(0.003)$ & $1.67(0.001)$ & $0.06(0.002)$ & $3.90(0.0008)$ \\
\hline S. paniculatum ${ }^{15}$ & $50.6(0.10)$ & $3.84(0.002)$ & $1.62(0.002)$ & $0.06(0.002)$ & $0.42(0.0001)$ \\
\hline $\mathrm{p}^{*} \mathrm{e}^{15}$ & $50.6(0.09)$ & $3.77(0.004)$ & $1.62(0.003)$ & $0.06(0.003)$ & $0.41(0.0002)$ \\
\hline I. edulis ${ }^{15}$ & $50.5(0.11)$ & $3.64(0.001)$ & $1.60(0.001)$ & $0.06(0.004)$ & $0.39(0.0001)$ \\
\hline Control $^{\Psi}$ & $50.7(0.13)$ & & & $0.06(0.004)$ & \\
\hline
\end{tabular}

${ }^{14}$ after species name means that the treatment was added leaf material (older material) with ${ }^{15} \mathrm{~N}$ at natural abundance $\left(0.366\right.$ atom $\left.\%{ }^{15} \mathrm{~N}\right)$ and was fertilized with enriched ${ }^{15} \mathrm{~N}$-urea $\left(5.320\right.$ atom $\left.\%{ }^{15} \mathrm{~N}\right)$. ${ }^{15}$ after species name means that the treatment was added previously ${ }^{15} \mathrm{~N}$-enriched leaf material (younger material) and was fertilized with ${ }^{14} \mathrm{~N}$-urea.

The chemical characteristics of the leaf material are presented in Table 22. The different amounts of leaf material and the species' age affect lignin, cellulose, phenol and $\mathrm{P}$ concentrations as is evident for the old material used in the experiment with leaf material without enriched $\mathrm{N}$ (Table 22, number ${ }^{14}$ after species name). 
Table 22. Chemical characteristics of leaf material from different legume species added to soil in laboratory incubation experiment. The number represents Mean(Standard deviation) with $\mathrm{n}$ $=12$.

\begin{tabular}{lcccc}
\hline \multirow{2}{*}{ Treatment } & Lignin & Cellulose & Phenol & P \\
\cline { 2 - 5 } & & \multicolumn{2}{c}{$\mathrm{mg} \mathrm{g}^{-1}$ soil } \\
\hline S. paniculatum $^{14}$ & $26.2(0.013)$ & $13.5(0.007)$ & $6.17(0.003)$ & $0.07(0.0000)$ \\
$\mathrm{p}^{*} \mathrm{e}^{14}$ & $21.2(0.019)$ & $11.7(0.009)$ & $5.02(0.005)$ & $0.08(0.0001)$ \\
I. edulis $^{14}$ & $16.3(0.002)$ & $10.1(0.001)$ & $3.90(0.000)$ & $0.09(0.0001)$ \\
S. paniculatum $^{15}$ & $20.0(0.008)$ & $12.8(0.005)$ & $6.43(0.003)$ & $0.07(0.0000)$ \\
$\mathrm{p}^{*} \mathrm{e}^{15}$ & $21.4(0.024)$ & $14.7(0.029)$ & $6.17(0.004)$ & $0.11(0.0006)$ \\
I. edulis $^{15}$ & $22.3(0.082)$ & $16.2(0.060)$ & $5.82(0.022)$ & $0.14(0.0005)$ \\
\hline
\end{tabular}

${ }^{14}$ after species name means that the treatment was added leaf material (older material) with ${ }^{15} \mathrm{~N}$ at natural abundance $\left(0.366\right.$ atom $\left.\%{ }^{15} \mathrm{~N}\right)$ and was fertilized with enriched ${ }^{15} \mathrm{~N}$-urea $\left(5.320\right.$ atom $\left.\%{ }^{15} \mathrm{~N}\right)$. ${ }^{15}$ after species name means that the treatment was added previously ${ }^{15} \mathrm{~N}$-enriched leaf material (younger material) and was fertilized with ${ }^{14} \mathrm{~N}$-urea.

As with the $\mathrm{N}$ concentration described above, some of the chemical characteristics showed differences in concentration between the two experiments with the same species (Table 22). The differences probably resulted from the different plant ages (Constantinides and Fownes 1994a) as well as the different amounts of leaf material added in this experiment (Table 21). The older material with $\mathrm{N}$ at natural abundance $\left({ }^{14}\right.$ after the scientific name) originates from 30 -month-old plants (Brienza 1999), and the younger material with enriched ${ }^{15} \mathrm{~N}\left({ }^{15}\right.$ after the scientific name) from a 17-month experiment (Paparcikova et al. 2000).

\subsubsection{Nitrogen mineralization and immobilization in soil using rice as an indicator plant}

\subsubsection{Total mineral nitrogen ( $\mathrm{N}-\mathrm{min})$}

The two greenhouse experiments with contrasting legume material and different material ages showed a significant $(\mathrm{P}<0.01)$ decrease in the $\mathrm{N}$-min concentration during the incubation period (Figure 19). At the beginning of the greenhouse incubation experiment using rice as an indicator plant, total initial $\mathrm{N}$-mineralization was only significantly higher $(\mathrm{P}<0.01)$ for the $I$. $e^{\text {edulis }}{ }^{14}$ treatment (Figure $19 \mathrm{~A}$ and B). In this treatment, only small amounts of leaf material were added (Table 21) thus leading to low lignin and phenol concentrations (Table 22). The 
other treatments did not show an initial statistical difference $(\mathrm{P}>0.05)$ at the beginning of the incubation period.

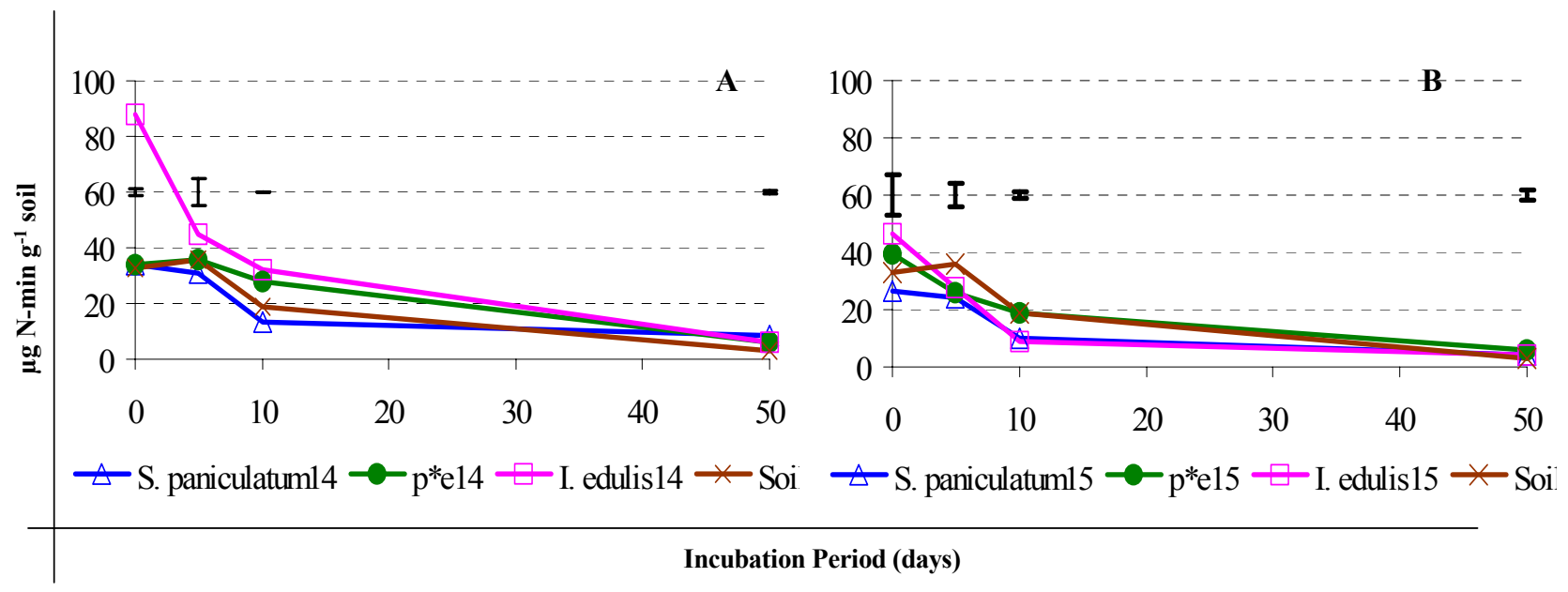

Figure 19. (A) Total nitrogen mineralization $\left(\mu \mathrm{g}{ }^{14} \mathrm{~N}+{ }^{15} \mathrm{~N}-\mathrm{min}^{-1}\right.$ soil) during the greenhouse incubation period (days) for samples with ${ }^{14} \mathrm{~N}$ leaf material and fertilized with enriched ${ }^{15} \mathrm{~N}$ urea ( ${ }^{14}$ after species name), (B) and samples with ${ }^{15} \mathrm{~N}$ enriched leaf material and fertilized with ${ }^{14} \mathrm{~N}$-urea $\left({ }^{15}\right.$ after species name). Soil as control was soil without leaf material and fertilized with ${ }^{14} \mathrm{~N}$-urea. The bars represent $\mathrm{LSD}_{<0.05}$.

After ten days of greenhouse incubation, the I. edulis ${ }^{14}$ and $\mathrm{p}^{*} \mathrm{e}^{14}$ treatments showed a significantly higher mineral $\mathrm{N}$ concentration than the other treatments (Figure $19 \mathrm{~A}$ and B). In the experiment using the larger amount of leaf material (with the younger leaf material, see Table 21) with, the higher lignin and phenol concentrations, the I. edulis and $\mathrm{p}^{*} \mathrm{e}$ mixture treatments showed significantly less accumulated mineral $\mathrm{N}$, by a factor of 3.6 and 1.5 respectively, in comparison with the treatments with older material. In the case of $S$. paniculatum, no statistical difference between the two ages of material was observed. At the end of the incubation period, S paniculatum ${ }^{14}$, which presented an initially higher phenol and lignin concentration, showed significantly higher $(\mathrm{P}<0.01)$ mineral $\mathrm{N}$ in the soil than the other treatment. At the same time, no statistical differences between I. edulis and the control were observed, irrespective of material age.

\subsubsection{Nitrogen mineralization $\left(\mathrm{NH}_{4}{ }^{+}-\mathrm{N}\right.$ concentration $)$}

With regard to mineralization, the same patterns of total mineral $\mathrm{N}$ concentration were observed for all treatments (Figure $20 \mathrm{~A}$ and B) after steam distillation analysis. Control showed a lower $\mathrm{NH}_{4}{ }^{+}-\mathrm{N}$ concentration, which did not differ statistically from the $\mathrm{p}^{*} \mathrm{e}^{15}$ and $I$. 
edulis ${ }^{15}$ treatments. The marked decrease in the $\mathrm{NH}_{4}{ }^{+}-\mathrm{N}$ concentration seemed to be the result of stronger competition for this nutrient between rice and microbial biomass.

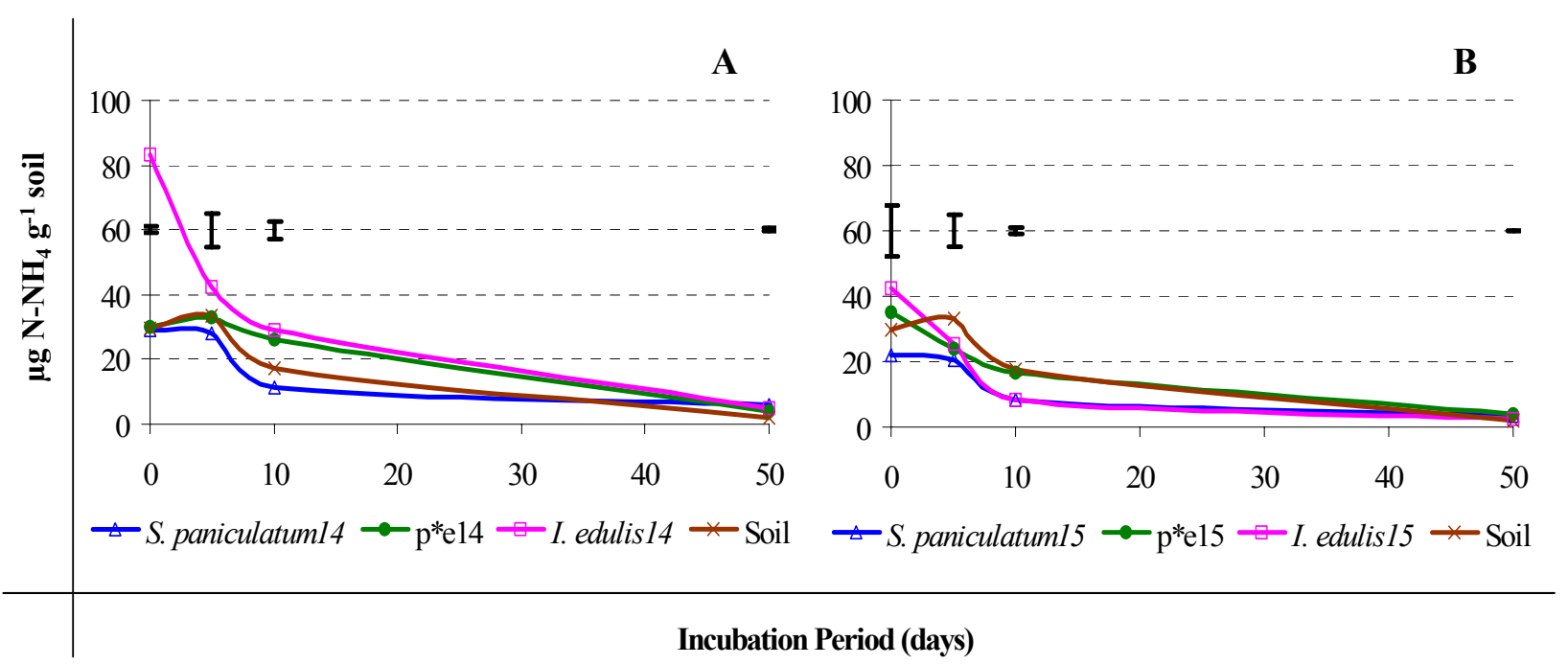

Figure 20. (A) Nitrogen mineralization ( $\mu \mathrm{g} \mathrm{NH}_{4}{ }^{+}-\mathrm{N} \mathrm{g}^{-1}$ soil) during the greenhouse incubation period (days) for samples with ${ }^{14} \mathrm{~N}$ leaf material and fertilized with enriched ${ }^{15} \mathrm{~N}$-urea $\left({ }^{14}\right.$ after species name), (B) and samples with ${ }^{15} \mathrm{~N}$ enriched leaf material and fertilized with ${ }^{14} \mathrm{~N}$-urea $\left({ }^{15}\right.$ after species name). Control was soil without added leaf material and fertilized with ${ }^{14} \mathrm{~N}$-urea. The bars represent $\mathrm{LSD}_{<0.05}$.

\subsubsection{Nitrogen microbial immobilization}

Nitrogen immobilization estimated by the fumigation-extraction method showed a contrasting pattern between differently aged materials in the two experiments (Figure $21 \mathrm{~A}$ and B).

Generally at the beginning of the experiment, the microbial biomass-N with the small amount of added leaf material behaved exactly opposite to the experiment with the larger amount of leaf material added. The control treatment initially showed a faster decrease in microbial biomass-N, which increased again at the end of the experiment.

In the $S$. paniculatum ${ }^{14}$ and $\mathrm{p}^{*} \mathrm{e}^{15}$ mixture treatments, a significantly slower initial $\mathrm{N}$ immobilization was observed, which increased toward the end of the experiment. The $I$. edulis ${ }^{14}$ and I. edulis ${ }^{15}$ treatments behaved contrastingly in the two experiments for the first ten days of incubation. However, at the end of the experiments with this species, a decrease in $\mathrm{N}$ immobilization was observed. After five days of incubation, the S. paniculatum $^{15}$ treatment $^{2}$ exhibited an approximately constant $\mathrm{N}$ immobilization. 
A

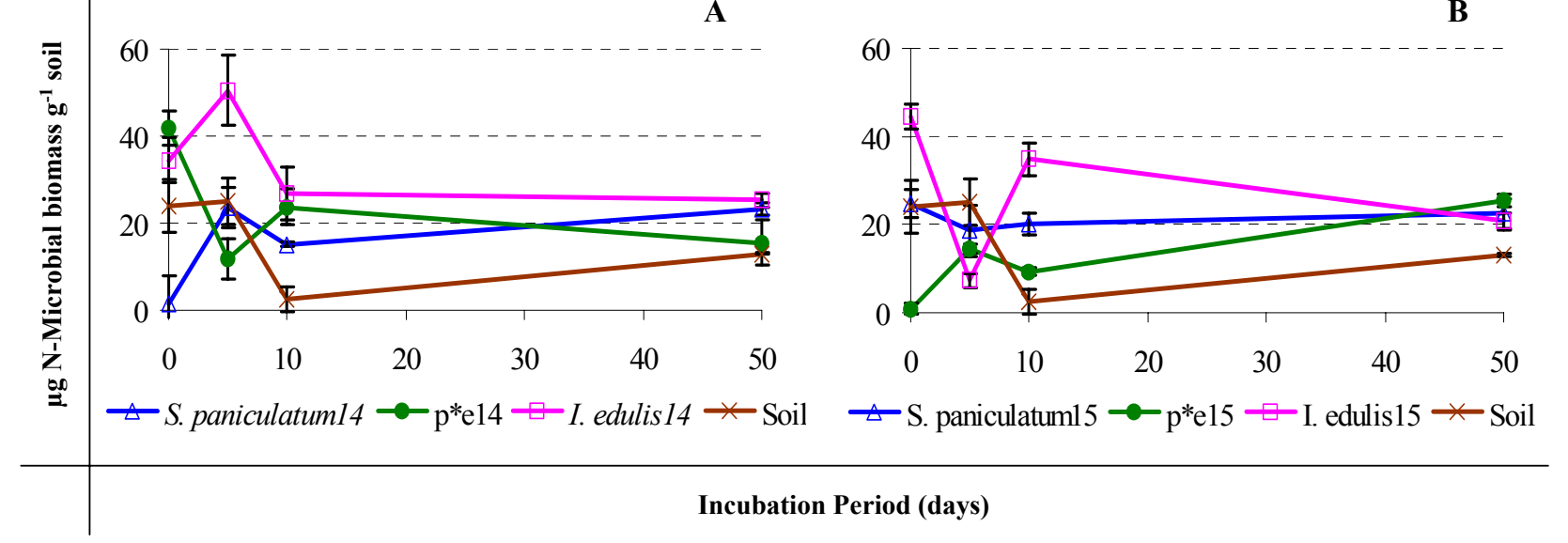

Figure 21. (A) Nitrogen microbial biomass $\left(\mu \mathrm{g} \mathrm{NH}_{4}{ }^{+}-\mathrm{N} \mathrm{g}^{-1}\right.$ soil) during the greenhouse incubation period (days) for samples with ${ }^{14} \mathrm{~N}$ leaf material and fertilized with enriched urea${ }^{15} \mathrm{~N}\left({ }^{14}\right.$ after species name), (B) and samples with ${ }^{15} \mathrm{~N}$ enriched leaf material and fertilized with urea- ${ }^{14} \mathrm{~N}$ ( ${ }^{15}$ after species name). Soil treatment (as control) was soil without added leaf material and fertilized with urea- ${ }^{14} \mathrm{~N}$. The bars represent Standard error of the mean.

Compared with the laboratory experiment, the greenhouse experiment with rice as an indicator plant showed a higher microbial activity. This higher microbial activity could be the result of a high temperature variation in comparison with the controlled conditions in the laboratory experiment but may be due to a rhizosphere effect as well.

\subsubsection{4 $\mathrm{N}$ nitrification $\left(\mathrm{NO}_{3}^{-}-\mathrm{N}\right.$ concentration) in the soil}

Nitrification was not statistically different between the two experiments at the onset of the experiments (Figure $22 \mathrm{~A}$ and B). However, the legume treatment initially showed a significantly higher $\mathrm{NO}_{3}{ }^{-}-\mathrm{N}$ concentration than the control. This initially higher $\mathrm{NO}_{3}{ }^{-}-\mathrm{N}$ concentration is presumably due to the higher initial microbial activity mentioned above. Jansson (1958) and Jenkinson et al. (1985) also reported that ammonium-N $\left(\mathrm{NH}_{4}{ }^{+}-\mathrm{N}\right)$ is normally favored over nitrate- $\mathrm{N}\left(\mathrm{NO}_{3}{ }^{-} \mathrm{-N}\right)$ in the immobilization process. 


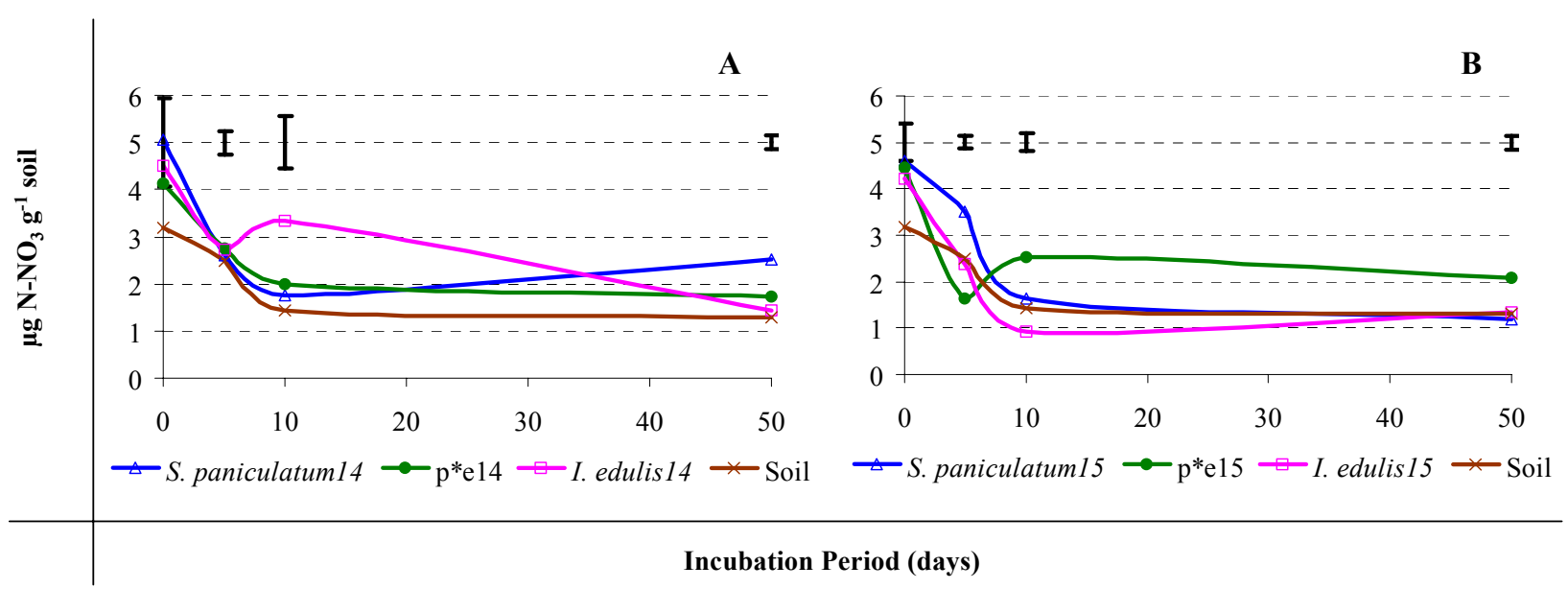

Figure 22. (A) Nitrification ( $\mu \mathrm{g} \mathrm{NO}_{3}{ }^{-}-\mathrm{N} \mathrm{g}^{-1}$ soil) during the greenhouse incubation period (days) for samples with ${ }^{14} \mathrm{~N}$ leaf material and fertilized with enriched urea- ${ }^{15} \mathrm{~N}\left({ }^{14}\right.$ after species name), and (B) samples with ${ }^{15} \mathrm{~N}$ enriched leaf material and fertilized with urea- ${ }^{14} \mathrm{~N}\left({ }^{15}\right.$ after species name). Soil treatment (as control) was soil without added leaf material and fertilized with urea- ${ }^{14} \mathrm{~N}$. The bars represent $\mathrm{LSD}_{<0.05}$.

Five days after the onset of the incubation period, the experiment with low amounts of added leaf material did not show a statistical variation in nitrification from the control (Figure $22 \mathrm{~A}$ ), Significantly higher $\mathrm{NO}_{3}{ }^{-}-\mathrm{N}$ concentrations were found in the $S$. paniculatum ${ }^{15}$ and lower $(\mathrm{P}<$

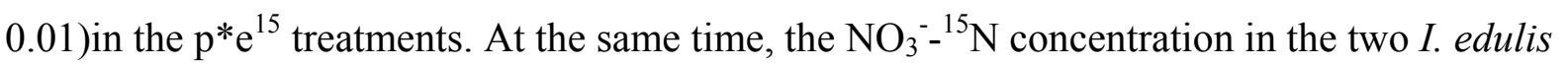
experiments did not differ significantly from the control (Figure $22 \mathrm{~A}$ and $\mathrm{B}$ ).

Ten days after the onset of the experiment, nitrification in the I. edulis ${ }^{14}$ treatment increased. The nitrate concentration was significantly higher than in the soil with the younger leaf material, which initially showed a comparatively higher lignin + phenol content (Table 22) and a significantly lower $\mathrm{NO}_{3}{ }^{-}-\mathrm{N}$ concentration (Figure $22 \mathrm{~B}$ ). At the end of the experiment, only the $S$. paniculatum ${ }^{14}$ and $\mathrm{p}^{*} \mathrm{e}^{15}$ treatments showed a significantly higher $\mathrm{NO}_{3}{ }^{-} \mathrm{N}$ concentration in the soil than the control.

\subsubsection{Nitrogen mineralization in soil amended with ${ }^{14} \mathrm{~N}$-legume leaf material and enriched ${ }^{15} \mathrm{~N}$-urea fertilizers with rice as an indicator plant}

\subsubsection{Rice biomass and $\mathbf{N}$ content in rice during the greenhouse experiment}

Total rice biomass and total $\mathrm{N}$ in rice was affected by $\mathrm{N}$ from the legume leaves in the amended soil during the incubation period (Figure 23). Initial rice dry matter was not statistically different at the time of transplantation. 


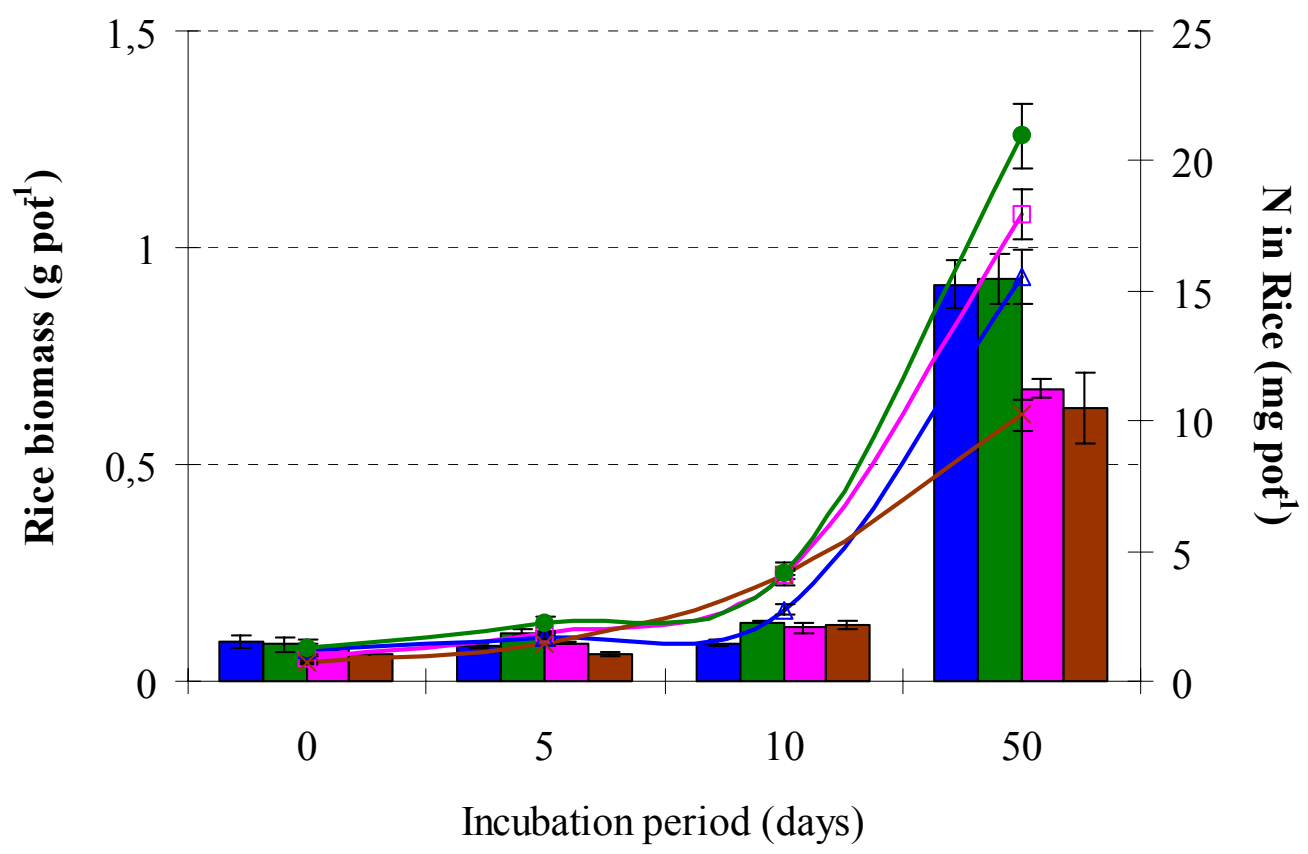

$\square$ S. paniculatum $\square \mathrm{p}^{*} \mathrm{e} \quad \square$ I. edulis $\quad \square$ Control

Figure 23. Rice dry matter (g $\operatorname{pot}^{-1}$, boxes) and total $\mathrm{N}$ in plant material ( $\mathrm{mg} \mathrm{N}$ pot ${ }^{-1}$, lines) growing in soil with leaf- ${ }^{14} \mathrm{~N}$ legume material and mixture using enriched urea- ${ }^{15} \mathrm{~N}$ fertilizer. Control was soil that only included urea- ${ }^{14} \mathrm{~N}$ fertilizer. Bars represent standard error of the mean.

Ten days after the rice plants had been transplanted, the $S$. paniculatum treatment showed a significantly lower rice biomass and $\mathrm{N}$ content than the other legume treatments and the control. At the end of the experiment, the S. paniculatum treatment did not differ statistically from the $\mathrm{p}^{*}$ e mixture treatment, which had a significantly higher $(\mathrm{P}<0.05)$ dry matter than $I$. edulis and the control treatment.

Although the $\mathrm{N}$ uptake by rice in the $\mathrm{p}^{*} \mathrm{e}$ mixture treatment did not differ statistically from that in the I. edulis treatment at the end of incubation period, it was significantly higher than the S. paniculatum and the control treatments (Figure 23). All treatments showed a significantly $(\mathrm{P}<0.01)$ higher total $\mathrm{N}$ content in comparison with the control.

\subsubsection{Nitrogen recovered by rice}

The increases of $\mathrm{N}$ recovery and ${ }^{15} \mathrm{~N}$ excess in rice showed contrasting patterns (Figure 24). Treatment with the mixture of two legumes species showed a high recovery of $\mathrm{N}$ and ${ }^{15} \mathrm{~N}$ in comparison to the two legume species. Recovery of ${ }^{15} \mathrm{~N}$ from rice was significantly higher (P 
$<0.001)$ in the $S$. paniculatum treatment than with the I. edulis treatment. In contrast, the recovery of total $\mathrm{N}$ was higher for the I. edulis than for S. paniculatum.
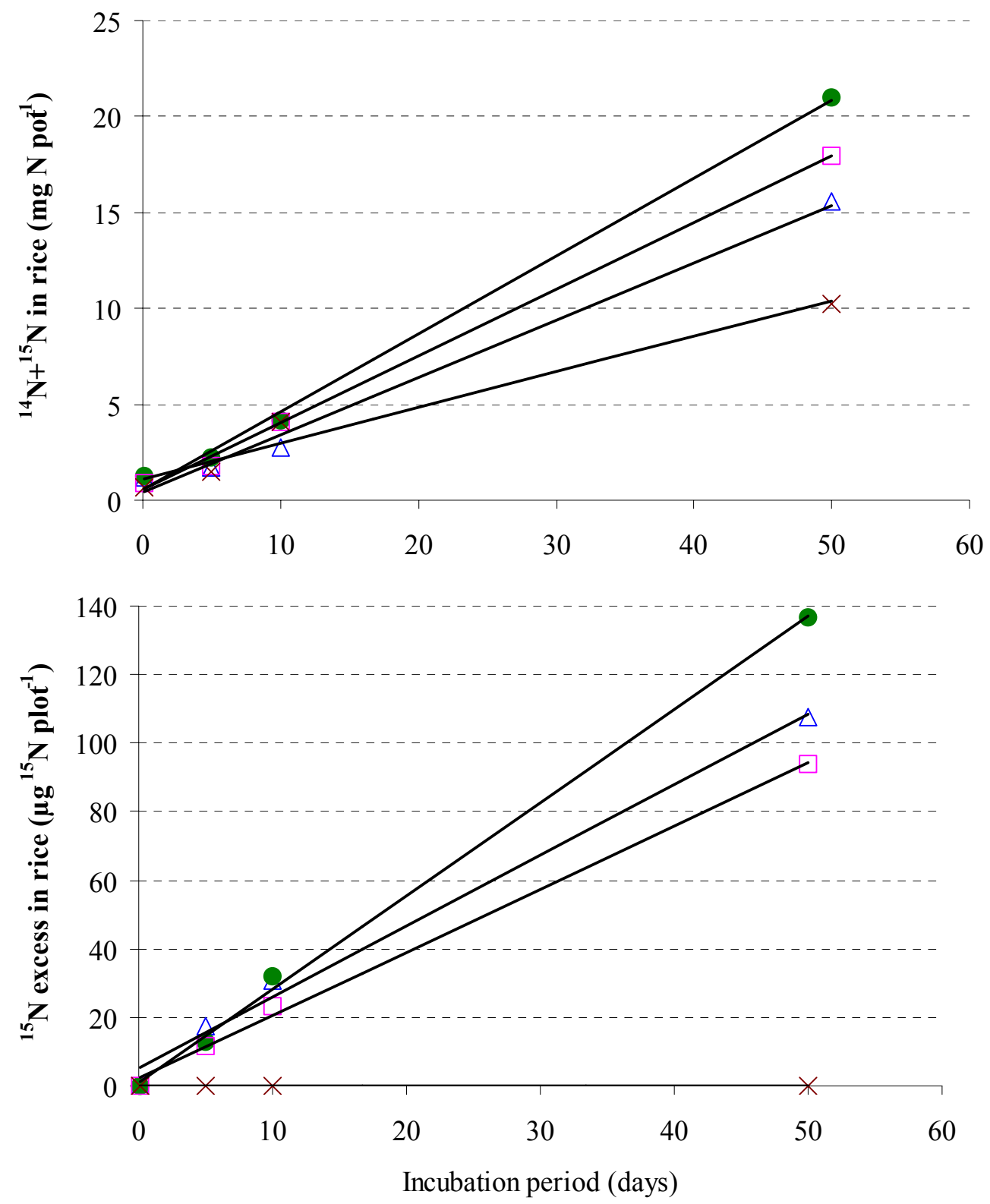

$\triangle$ S. paniculatum $\quad \mathrm{p}^{* \mathrm{e}} \quad \square$ I. edulis $\quad \times$ Control

Figure $24 .{ }^{14} \mathrm{~N}+{ }^{15} \mathrm{~N}$ and ${ }^{15} \mathrm{~N}$ recovery by rice in soil amended with ${ }^{14} \mathrm{~N}$-leaf material from two different legumes species and mixture with ${ }^{15} \mathrm{~N}$-urea fertilizer in comparison with soil without leaf material and fertilized with $\mathrm{N}$-urea (Control), for different incubation periods. The ${ }^{15} \mathrm{~N}$ is expressed as the atom $\%{ }^{15} \mathrm{~N}$ excess abundance above the background $(0.3663$ atom \%).

It is interesting to observe that the lowest recovery of the excess ${ }^{15} \mathrm{~N}$ by rice was consistently observed with the higher C-to-N ratio treatment (Table 21), demonstrating that incomplete 
immobilization has a significant effect on the ${ }^{15} \mathrm{~N}$ enrichment of the inorganic N-pool and highlights the problems associated with adding residues and inorganic $\mathrm{N}$ simultaneously.

\subsubsection{Nitrogen concentration in rice}

The total nitrogen concentration in rice during the first 10 days of incubation did not differ for the amended soils or the control (Table 23). At the end of incubation period, I. edulis, with an $\mathrm{N}$ concentration of $26.6 \mathrm{mg} \mathrm{N} \mathrm{g}^{-1}$ dry matter, did not differ statistically from the $\mathrm{p}^{*} \mathrm{e}$ mixture (22.8 $\mathrm{mg} \mathrm{N} \mathrm{g}^{-1}$ dry matter). However, I. edulis showed a higher of $\mathrm{N}$ than the control (17.4 mg $\mathrm{N} \mathrm{g}^{-1}$ dry matter) and the $S$. paniculatum $\left(17.0 \mathrm{mg} \mathrm{N} \mathrm{g}^{-1}\right.$ dry matter) in the same time.

Table 23. Nitrogen concentration ( $\mathrm{mg} \mathrm{N} \mathrm{g}^{-1}$ dry matter) for different treatment and the control during the incubation time (days). Control was soil without added leaf material.

\begin{tabular}{lcccc}
\hline $\begin{array}{l}\text { Treatment / Incubation } \\
\text { period (days) }\end{array}$ & \multicolumn{4}{c}{ Nitrogen concentration $\left(\mathrm{mg} \mathrm{N} \mathrm{g}^{-1}\right.$ dry matter) } \\
\cline { 2 - 5 } & 0 & 5 & 10 & 50 \\
\hline S. paniculatum & 12.8 & 20.4 & 31.2 & 17.0 \\
p*e & 14.3 & 19.8 & 30.9 & 22.8 \\
I. edulis & 11.8 & 20.5 & 33.2 & 26.6 \\
Control & 11.6 & 23.4 & 31.7 & 17.4 \\
\cline { 2 - 5 } & $2.27^{\mathrm{NS}}$ & $3.60^{\mathrm{NS}}$ & $2.00^{\mathrm{NS}}$ & $5.82^{*}$
\end{tabular}

LSD compares different treatment at the same sampling time; ${ }^{\text {NS }}$ is not significant; ${ }^{*}=\mathrm{P}<0.05$

In contrast, after 50 days of incubation period total $\mathrm{N}$ concentration in rice dry matter was not significantly different $(\mathrm{P}>0.05)$ to the $\mathrm{p}^{*} \mathrm{e}$ mixture and I. edulis treatments (Table 23). These two treatments differed considerably in comparison to the $S$. paniculatum and control treatments. It was seen that the rice in the $\mathrm{p}^{*} \mathrm{e}$ mixture treatment exhibited the same patterns of grown as the I. edulis treatment but with a higher productivity.

\subsubsection{Nitrogen derived from fertilizer (NdfF) and from legume leaf material (NdfLM ${ }^{16}$ )}

Nitrogen in rice derived from ${ }^{15} \mathrm{~N}$-fertilizer $(\mathrm{NdfF})$ and ${ }^{14} \mathrm{~N}$-leaf material (NdfLM) were clearly influenced by the different legume leaf material incorporated in the soil (Table 24). Nitrogen derived from fertilizer in rice decreased by $0.16 \mathrm{mg} \mathrm{N}_{\text {pot }}^{-1}$ in the $S$ paniculatum

\footnotetext{
${ }^{16}$ The NdfLM is the difference between $\mathrm{N}$ content in rice in treatments with added leaf material and control (soil without added leaf material).
} 
treatment, and increased by 0.38 and $0.24 \mathrm{mg} \mathrm{N}_{\text {pot }}{ }^{-1}$ in the $\mathrm{p}^{*} \mathrm{e}$ mixture and I. edulis treatments, respectively, between 5 and 10 days of greenhouse incubation.

In the $\mathrm{p}^{*}$ e mixture treatment, a higher $\mathrm{NdfF}$ at 50 days of incubation was observed. This result, however, did not differ statistically from the S. paniculatum treatment. When both organic and inorganic $\mathrm{N}$ fertilizers are applied, the availability of the inorganic $\mathrm{N}$ fertilizer is greatly influenced by the presence of organic fertilizer (Hood et al. 2000) and by the quality of the organic fertilizer.

A decrease in nitrogen derived from leaf material between 5 and 10 days of incubation was observed in all legume treatments (Table 24). This suggests that during this period, the microorganism activity was high, resulting in $\mathrm{N}$ immobilization and consumption. At the end of the study period, rice growing in soil with the $\mathrm{p}^{*} \mathrm{e}$ mixture showed a significantly higher amount of $\mathrm{N}$, which came from the added leaf material. The same was true for the I. edulis treatment.

Total nitrogen in rice derived from fertilizer increased $20.8 \%, 12.7 \%$ and $11.8 \%$ during the first 5 days of the incubation period in S. paniculatum, I. edulis and the $\mathrm{p}^{*}$ e mixture, respectively. For the same period, increases in nitrogen derived from leaf material were $34.2 \%, 19.2 \%$ and $13.2 \%$ of the total $\mathrm{N}$ in rice for the $\mathrm{p}^{*}$ e mixture, I. edulis and $S$. paniculatum treatments, respectively (Table 24). 
Table 24. Nitrogen derived from fertilizer $(\mathrm{NdfF})$ and nitrogen derived from added leaf material (NdfLM) in rice during the greenhouse study with different leaf legume treatments incorporated in the soil.

\begin{tabular}{|c|c|c|c|c|}
\hline \multicolumn{5}{|l|}{ NdfF $(\%)$} \\
\hline \multirow[t]{2}{*}{ Treatment } & \multicolumn{4}{|c|}{ Incubation period (days) } \\
\hline & 0 & 5 & 10 & 50 \\
\hline S. paniculatum & 0.16 & 20.98 & 22.18 & 14.14 \\
\hline $\mathrm{p}^{*} \mathrm{e}$ & 0.10 & 11.88 & 15.35 & 13.24 \\
\hline I. edulis & 0.11 & 12.77 & 11.54 & 10.69 \\
\hline $\operatorname{LSD}^{\Omega}$ & $0.07^{\mathrm{NS}}$ & $0.90^{* * *}$ & $3.81^{* *}$ & $0.80^{*}$ \\
\hline \multicolumn{5}{|l|}{ NdfF (mg) } \\
\hline \multirow{2}{*}{ Treatment } & \multicolumn{4}{|c|}{ Incubation period (days) } \\
\hline & 0 & 5 & 10 & 50 \\
\hline S. paniculatum & 0.002 & 0.35 & 0.19 & 2.17 \\
\hline $\mathrm{p}^{*} \mathrm{e}$ & 0.001 & 0.26 & 0.64 & 2.76 \\
\hline I. edulis & 0.001 & 0.23 & 0.47 & 1.89 \\
\hline $\operatorname{LSD}^{\Omega}$ & $0.01^{\mathrm{NS}}$ & $0.09^{*}$ & $0.18^{\mathrm{NS}}$ & $0.28^{* *}$ \\
\hline \multicolumn{5}{|l|}{$\operatorname{NdfLM}^{\Phi}(\mathrm{mg})$} \\
\hline \multirow{2}{*}{ Treatment } & \multicolumn{4}{|c|}{ Incubation time (days) } \\
\hline & 0 & 5 & 10 & 50 \\
\hline S. paniculatum & 0.51 & 0.22 & -1.31 & 5.3 \\
\hline $\mathrm{p}^{*} \mathrm{e}$ & 0.56 & 0.76 & 0.11 & 10.73 \\
\hline I. edulis & 0.22 & 0.35 & 0.02 & 7.71 \\
\hline $\mathrm{LSD}^{\Omega}$ & $0.34^{\mathrm{NS}}$ & $0.54^{\mathrm{NS}}$ & $0.09^{* *}$ & $3.02^{*}$ \\
\hline
\end{tabular}

\footnotetext{
${ }^{\Phi}$ Nitrogen derived from added leaf material was calculated by subtraction of the nitrogen content in rice with added legume leaf material from the nitrogen content in rice without added leaf material. ${ }^{\Omega} \mathrm{LSD}$ compares the treatments at the same incubation period; and ${ }^{\mathrm{NS}}$ is not significant, ${ }^{* *}=\mathrm{P}<0.01$; ${ }^{* * *}=\mathrm{P}<0.001$.
} 
After 50 days of incubation, total nitrogen in rice derived from fertilizer was $14.0 \%, 13.1 \%$ and $10.5 \%$ for the S. paniculatum, $\mathrm{p}^{*} \mathrm{e}$ mixture and I. edulis treatments, respectively. At the same time, $\mathrm{N}$ derived from leaf material was $51.2 \%, 43.0 \%$ and $34.2 \%$ for the $\mathrm{p}^{*} \mathrm{e}$ mixture and I. edulis and S. paniculatum treatments, respectively. These results showed that the mixture of two different legume leaf materials increased the rice's uptake of $\mathrm{N}$ derived from fertilizer and from legume leaf decomposition when compared with the same species applied in separate treatments.

\subsubsection{5 ${ }^{15} \mathrm{~N}$-mineral ${ }^{-}$concentration in soil using incorporated ${ }^{14} \mathrm{~N}$-legume leaf material} and enriched ${ }^{15} \mathrm{~N}$-urea fertilizers with rice as an indicator plant

\subsection{Soil $\mathrm{NH}_{4}{ }_{-}^{+}{ }^{14} \mathrm{~N}$ and $\mathrm{NH}_{4}{ }^{+}{ }^{15} \mathrm{~N}$ concentration}

A strong decrease in $\mathrm{NH}_{4}{ }^{+}-\left({ }^{14} \mathrm{~N}+{ }^{15} \mathrm{~N}\right)$ and $\mathrm{NH}_{4}{ }^{+}-{ }^{15} \mathrm{~N}$ excess in the soil during the incubation period was observed in all treatments (Table 25). This means that the competition between rice and microorganisms for mineral $\mathrm{N}$ was very intense. The significant differences in $\mathrm{NH}_{4}{ }^{+}-$ $\mathrm{N}$ at time-zero suggests that the initial decomposition in the I. edulis and $\mathrm{p}^{*} \mathrm{e}$ mixture treatments was more rapid when compared with the $S$. paniculatum treatment at day 6 of the pre-incubation period.

The significantly $(\mathrm{P}<0.01)$ more rapid decrease initially in soil total $\mathrm{NH}_{4}{ }^{+}-\left({ }^{14} \mathrm{~N}+{ }^{15} \mathrm{~N}\right)$ and $\mathrm{NH}_{4}{ }^{+}-{ }^{15} \mathrm{~N}$ excess for the $S$. paniculatum treatment suggests that this treatment experienced a higher $\mathrm{N}$ absorption by rice and/or soil immobilization in combination with a low initial leaf material decomposition, when compared with the other legume treatments and control (Table 25 ). It can thus be assumed that the microorganisms in the $S$. paniculatum treatment use urea$\mathrm{N}$ for initial decomposition of richer $\mathrm{C}$ material. 
Table 25. Total $\mathrm{NH}_{4}{ }^{+}-\left({ }^{14} \mathrm{~N}+{ }^{15} \mathrm{~N}\right)\left(\mu \mathrm{g} \mathrm{N} \mathrm{g}{ }^{-1}\right.$ soil $)$ and $\mathrm{NH}_{4}{ }^{+}{ }^{15} \mathrm{~N}\left(\mu \mathrm{g}{ }^{15} \mathrm{Ng}^{-1}\right.$ soil $)$ excess in soil with different added ${ }^{14} \mathrm{~N}$-leaf legume material and ${ }^{15} \mathrm{~N}$-urea as fertilizer with rice as an indicator plant. Control was soil without added leaf material and fertilized with ${ }^{14} \mathrm{~N}$-urea. ${ }^{15} \mathrm{~N}$ excess is expressed as the atom $\%{ }^{15} \mathrm{~N}$ excess abundance above the background $(0.3663$ atom $\%)$.

\begin{tabular}{|c|c|c|c|c|}
\hline \multicolumn{5}{|c|}{$\mathrm{NH}_{4}{ }^{+}-\left({ }^{14} \mathrm{~N}+{ }^{15} \mathrm{~N}\right)\left(\mu \mathrm{g} \mathrm{N} \mathrm{g}^{-1}\right.$ soil $)$} \\
\hline \multirow[b]{2}{*}{ Treatment } & \multicolumn{4}{|c|}{ Incubation period (days) } \\
\hline & 0 & 5 & 10 & 50 \\
\hline S. paniculatum & 12.2 & 6.95 & 2.56 & 0.13 \\
\hline $\mathrm{p}^{*} \mathrm{e}$ & 13.5 & 13.3 & 12.2 & 0.30 \\
\hline I. edulis & 15.6 & 15.6 & 15.7 & 0.38 \\
\hline Control & 10.0 & 12.3 & 10.6 & 0.18 \\
\hline LSD & $1.29^{* *}$ & $0.98^{* * *}$ & $1.62^{* * *}$ & $0.05^{* * *}$ \\
\hline \multicolumn{5}{|c|}{$\mathrm{NH}_{4}{ }^{+}-{ }^{15} \mathrm{~N}$ excess $\left(\mu \mathrm{g}{ }^{15} \mathrm{Ng}^{-1}\right.$ soil $)$} \\
\hline S. paniculatum & $0.1621^{\mathrm{a}}$ & $0.0834^{\mathrm{b}}$ & $0.0223^{c}$ & $0.0001^{\mathrm{ab}}$ \\
\hline $\mathrm{p}^{*} \mathrm{e}$ & $0.1681^{\mathrm{a}}$ & $0.1743^{\mathrm{a}}$ & $0.0802^{\mathrm{b}}$ & $0.0003^{\mathrm{a}}$ \\
\hline I. edulis & $0.1569^{\mathrm{a}}$ & $0.1642^{\mathrm{a}}$ & $0.0947^{\mathrm{a}}$ & $0.0003^{\mathrm{a}}$ \\
\hline Control & $0.0001^{\mathrm{b}}$ & $0.0001^{\mathrm{c}}$ & $0.0002^{\mathrm{d}}$ & $0.0000^{\mathrm{b}}$ \\
\hline LSD & $0.0112^{*}$ & $0.0100^{* * *}$ & $0.0145^{* * *}$ & $0.0002^{*}$ \\
\hline
\end{tabular}

LSD compares different treatments at the same sampling time; NS is not significant; * $=\mathrm{P}<0.05$; ** $=\mathrm{P}<0.01$; and $* * *=\mathrm{P}<0.001$.

\subsection{Soil $\mathrm{NO}_{3^{-}}{ }^{14} \mathrm{~N}$ and $\mathrm{NO}_{3^{-}}{ }^{15} \mathrm{~N}$ concentration}

As with ammonium, the $\mathrm{NO}_{3}{ }^{-}-\left({ }^{14} \mathrm{~N}+{ }^{15} \mathrm{~N}\right)$ concentration decreased during the incubation period (Table 26). The proportionally higher decrease in the $\mathrm{NO}_{3}{ }^{-}-\left({ }^{14} \mathrm{~N}+{ }^{15} \mathrm{~N}\right)$ concentration was found in the $\mathrm{p}^{*}$ e mixture ( $74.6 \%$ of initial concentration) and S. paniculatum treatments (60.7\%), followed by the I. edulis treatment (31.9\%) and control (21.8\%). The significantly larger increase in the $\mathrm{NO}_{3}{ }^{-}-\mathrm{N}$ concentration in the first ten days of incubation for the control and I. edulis treatments, especially for ${ }^{15} \mathrm{NO}_{3}{ }^{-}$in the I. edulis treatment, implies that there was a significantly higher nitrification in comparison with consumption by soil microorganism or rice. 
Table 26. Total $\mathrm{NO}_{3}{ }_{-}^{-}-\left({ }^{14} \mathrm{~N}+{ }^{15} \mathrm{~N}\right)\left(\mu \mathrm{g} \mathrm{N} \mathrm{g}{ }^{-1}\right.$ soil $)$ and $\mathrm{NO}_{3}{ }^{-}{ }^{-15} \mathrm{~N}\left(\mu \mathrm{g}{ }^{15} \mathrm{Ng}^{-1}\right.$ soil) excess in soil amended with legume leaf material and ${ }^{15} \mathrm{~N}$-urea as fertilizer with rice as an indicator plant. Control was soil without added leaf material and fertilized with $\mathrm{N}$-urea. ${ }^{15} \mathrm{~N}$ excess is expressed as the atom $\%{ }^{15} \mathrm{~N}$ excess abundance above the background $(0.3663$ atom \%).

\begin{tabular}{|c|c|c|c|}
\hline \multicolumn{4}{|c|}{$\mathrm{NO}_{3}{ }^{-}-\left({ }^{14} \mathrm{~N}+{ }^{15} \mathrm{~N}\right)\left(\mu \mathrm{g} \mathrm{N} \mathrm{g}^{-1}\right.$ soil $)$} \\
\hline \multirow[b]{2}{*}{ Treatment } & \multicolumn{3}{|c|}{ Incubation period (days) } \\
\hline & 0 & 10 & 50 \\
\hline S. paniculatum & 1.73 & 1.54 & 0.68 \\
\hline $\mathrm{p}^{*} \mathrm{e}$ & 2.56 & 1.41 & $0.65^{\mathrm{b}}$ \\
\hline I. edulis & 1.60 & 1.79 & $1.09^{\mathrm{a}}$ \\
\hline Control & 1.10 & 1.80 & $0.86^{\mathrm{ab}}$ \\
\hline LSD & $1.46^{\mathrm{NS}}$ & $0.39^{\mathrm{NS}}$ & $0.23^{*}$ \\
\hline \multicolumn{4}{|c|}{$\mathrm{NO}_{3}{ }^{-1}{ }^{15} \mathrm{~N}\left(\mu \mathrm{g}{ }^{15} \mathrm{Ng}^{-1}\right.$ soil $)$} \\
\hline S. paniculatum & 0.0040 & $0.0014^{\mathrm{b}}$ & $0.0004^{\mathrm{ab}}$ \\
\hline $\mathrm{p}^{*} \mathrm{e}$ & 0.0048 & $0.0018^{\mathrm{b}}$ & $0.0006^{\mathrm{a}}$ \\
\hline I. edulis & 0.0037 & $0.0049^{\mathrm{a}}$ & $0.0007^{\mathrm{a}}$ \\
\hline Control & 0.0000 & $0.0000^{\mathrm{b}}$ & $0.0000^{\mathrm{b}}$ \\
\hline LSD & $0.0048^{\mathrm{NS}}$ & $0.0018^{* *}$ & $0.0003^{* *}$ \\
\hline
\end{tabular}

$\overline{\text { LSD compares different treatments in at the same sampling time }} ;{ }^{\mathrm{NS}}$ is not significant; ${ }^{*}=\mathrm{P}<0.05 ;{ }^{* *}$ $=\mathrm{P}<0.01$.

\subsection{Soil microbial biomass- ${ }^{14} \mathrm{~N}$ and microbial biomass $-{ }^{15} \mathrm{~N}$}

A marked difference between the treatments was observed with regard to nitrogen immobilization at the beginning of the experiment (Table 27). The control and I. edulis treatments showed a higher initial microbial biomass $-\left({ }^{14} \mathrm{~N}+{ }^{15} \mathrm{~N}\right)$ in comparison to the other treatments. These data point to the highest microbial activity in the pre-incubation period for these two treatments. After five days of rice growth, the $\mathrm{p}^{*}$ e mixture and S. paniculatum treatments showed a $368 \%$ and $350 \%$ increase in the microbial biomass $-\left({ }^{14} \mathrm{~N}+{ }^{15} \mathrm{~N}\right)$ concentration in comparison with an increase of $8.8 \%$ for the control and a decrease of $22.4 \%$ for the I. edulis treatment. 
Table 27. Microbial biomass- $\left({ }^{14} \mathrm{~N}+{ }^{15} \mathrm{~N}\right)\left(\mu \mathrm{g}{ }^{14} \mathrm{~N}+{ }^{15} \mathrm{Ng}^{-1}\right.$ soil $)$ and microbial biomass $-{ }^{15} \mathrm{~N}(\mu \mathrm{g}$ ${ }^{15} \mathrm{~N} \mathrm{~g}^{-1}$ soil) in soil amended with legume- ${ }^{14} \mathrm{~N}$ leaf material and enriched urea- ${ }^{15} \mathrm{~N}$ fertilizer with rice as an indicator plant. The ${ }^{15} \mathrm{~N}$ is expressed as the atom $\%{ }^{15} \mathrm{~N}$ excess abundance above the background ( 0.3663 atom \%).

\begin{tabular}{|c|c|c|c|c|}
\hline \multicolumn{5}{|c|}{ Microbial biomass- $\left({ }^{14} \mathrm{~N}+{ }^{15} \mathrm{~N}\right)\left(\mu \mathrm{g}{ }^{14} \mathrm{~N}+{ }^{15} \mathrm{~N} \mathrm{~g}{ }^{-1}\right.$ soil $)$} \\
\hline \multirow[b]{2}{*}{ Treatment } & \multicolumn{4}{|c|}{ Incubation period (days) } \\
\hline & 0 & 5 & 10 & 50 \\
\hline S. paniculatum & $0.55^{\mathrm{d}}$ & $2.48^{\mathrm{c}}$ & $3.29^{\mathrm{b}}$ & $2.55^{\mathrm{a}}$ \\
\hline $\mathrm{p}^{*} \mathrm{e}$ & $1.56^{\mathrm{c}}$ & $7.28^{\mathrm{a}}$ & $6.38^{\mathrm{a}}$ & $0.71^{\mathrm{c}}$ \\
\hline I. edulis & $3.69^{\mathrm{b}}$ & $2.86^{\mathrm{c}}$ & $1.67^{\mathrm{c}}$ & $1.11^{\mathrm{b}}$ \\
\hline Control & $4.66^{\mathrm{a}}$ & $5.07^{\mathrm{b}}$ & $2.65^{\mathrm{b}}$ & $1.02^{\mathrm{bc}}$ \\
\hline LSD & $0.261^{* * *}$ & $0.382^{* * *}$ & $0.645^{* * *}$ & $0.318^{* * *}$ \\
\hline \multicolumn{5}{|c|}{ Microbial biomass- ${ }^{15} \mathrm{~N}\left(\mu \mathrm{g}{ }^{15} \mathrm{~N}\right.$ excess $\mathrm{g}^{-1}$ soil $)$} \\
\hline S. paniculatum & $0.3132^{\mathrm{a}}$ & $0.1647^{\mathrm{a}}$ & $0.0546^{\mathrm{a}}$ & $0.0045^{\mathrm{a}}$ \\
\hline $\mathrm{p}^{* \mathrm{e}}$ & $0.2273^{\mathrm{a}}$ & $0.1115^{\mathrm{ab}}$ & $0.0558^{\mathrm{a}}$ & $0.0021^{\mathrm{b}}$ \\
\hline I. edulis & $0.0943^{\mathrm{b}}$ & $0.0487^{\mathrm{b}}$ & $0.0301^{\mathrm{b}}$ & $0.0016^{\mathrm{b}}$ \\
\hline Control & $0.0000^{\mathrm{c}}$ & $0.0000^{c}$ & $0.0000^{\mathrm{c}}$ & $0.0000^{\mathrm{c}}$ \\
\hline LSD & $0.0942^{* *}$ & $0.0628^{* *}$ & $0.0013^{* * *}$ & $0.0005^{* * *}$ \\
\hline
\end{tabular}

LSD compares the treatments at the same sampling time; $* *=\mathrm{P}<0.01 ; * * *=\mathrm{P}<0.001$.

The increases in microbial biomass-N continued only for the $S$. paniculatum treatment until day 10 of the incubation period, but at the end of the experiment only S. paniculatum showed a significantly higher microbial biomass- $\mathrm{N}$ compared to that observed at the onset of the experiment (Table 27). The mixture of the two legume species showed a strong decrease in microbial biomass-N when estimated with the fumigation-extraction method. At the end of the experiment the mixture treatment showed a significantly lower microbial biomass$\left({ }^{14} \mathrm{~N}+{ }^{15} \mathrm{~N}\right)$ in comparison with the single legume treatment.

In contrast, at the beginning of the experiment, the ${ }^{15} \mathrm{~N}$-microbial biomass concentration was significantly higher for the S. paniculatum and $\mathrm{p}^{*} \mathrm{e}$ mixture treatments than with the I. edulis and control treatments (Table 27). This means that the microorganisms in the S. paniculatum and $\mathrm{p}^{*} \mathrm{e}$ mixture treatments rapidly absorbed $\mathrm{N}$ that came from urea fertilizer, and used it for 
decomposing the recalcitrant organic material. During the whole sampling period, $S$.

paniculatum showed a significantly higher microbial biomass ${ }^{15} \mathrm{~N}$-concentration in comparison with the I. edulis treatment.

However, all legume treatments showed a decrease in ${ }^{15} \mathrm{~N}$-microbial biomass concentration, which can be either due to stronger microbial absorption of the $\mathrm{N}$ originating from incorporated leaf material, which diluted the ${ }^{15} \mathrm{~N}$ in the microbial biomass, or to a high microbial-N remineralization.

Since immobilization and mineralization of $\mathrm{N}$ occur simultaneously in the soil, previously immobilized $\mathrm{N}$ from urea is also remineralized (Recous et al. 1988, Choi et al. 2001). Increases in the amounts of immobilized urea-N suggest that the immobilization rate was higher than the remineralization rate of the $\mathrm{N}$ previously immobilized during rice growth.

\subsubsection{Nitrogen mineralization in soil amended with ${ }^{15} \mathrm{~N}$-legume leaf material and enriched ${ }^{14} \mathrm{~N}$-urea fertilizer with rice as an indicator plant}

\subsubsection{Rice biomass and $N$ content in rice during the greenhouse experiment}

Total rice biomass and total- $\left({ }^{14} \mathrm{~N}+{ }^{15} \mathrm{~N}\right)$ in rice growing on the soil amended with ${ }^{15} \mathrm{~N}$-legume leaf material showed a clear difference during 50 days of incubation period (Figure 25). At the end of the experiment, the $\mathrm{p}^{*}$ e mixture and S. paniculatum treatments showed a significantly $(\mathrm{P}<0.05)$ higher rice biomass than the I. edulis treatment.

After five days of incubation, rice growing in the I. edulis and $\mathrm{p}^{*} \mathrm{e}$ mixture treatments had a significantly $(\mathrm{P}<0.01)$ higher $\mathrm{N}$ content of 2.66 and $2.41 \mathrm{mg} \mathrm{N}$ pot $^{-1}$, respectively, than rice growing on S. paniculatum and the control treatment (1.93 and $1.58 \mathrm{mg} \mathrm{N}^{-1}$ pot $^{-1}$, respectively). This significantly higher increase remained only for I. edulis at 10 days (Figure 25). However, at the end of the experiment, only the $\mathrm{p}^{*}$ e mixture treatment had a significantly $(\mathrm{P}<0.01)$ higher $\mathrm{N}$ content in the rice than the other treatments, which, in turn, did not differ from the control. 


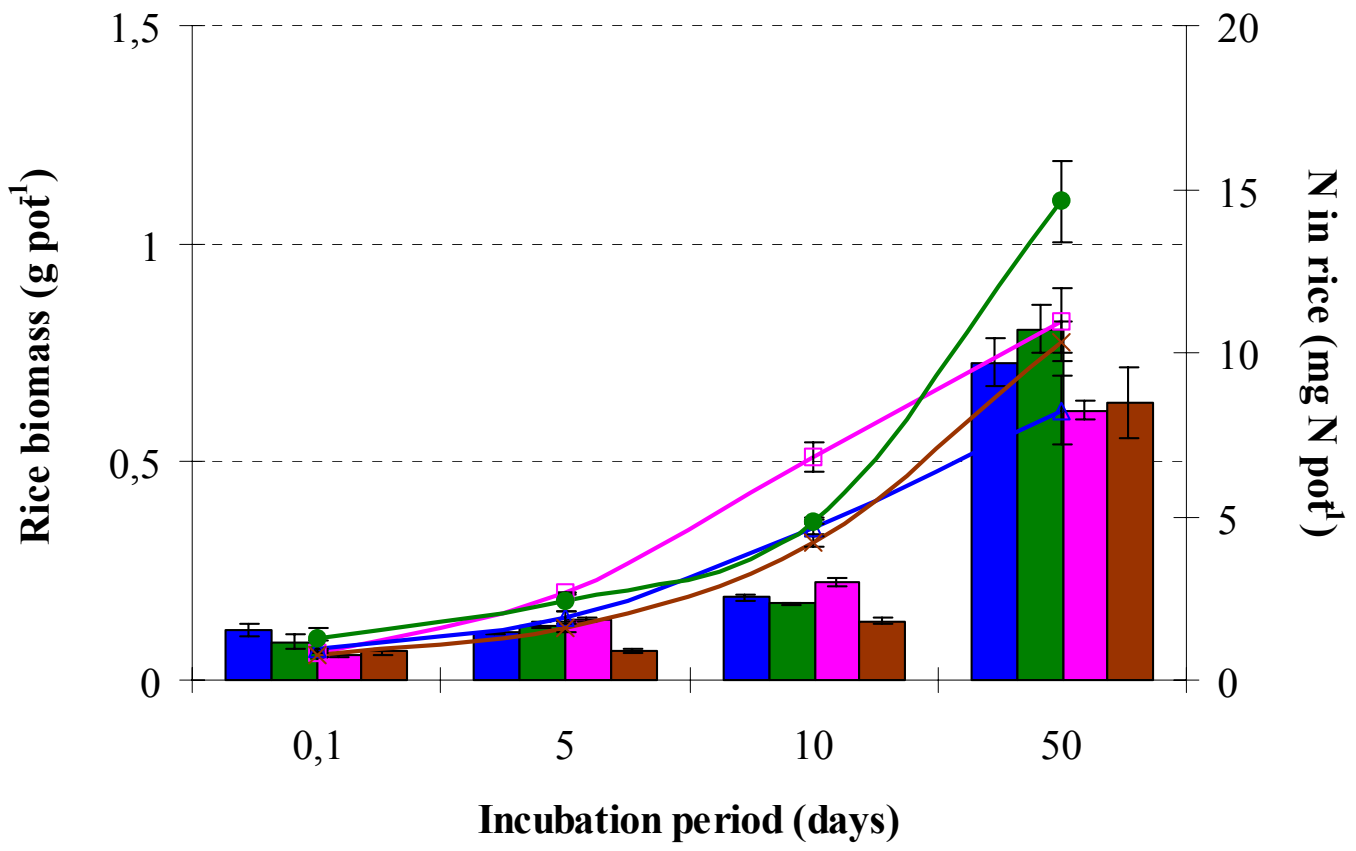

$\square$ S. paniculatum $\square$ p*e $\square$ I. edulis $\quad \square$ Control

Figure 25. Dry matter (g pot ${ }^{-1}$, boxes) and total $\mathrm{N}$ in plant material ( $\mathrm{mg} \mathrm{N} \operatorname{pot}^{-1}$, lines) for rice growing in soil with ${ }^{14} \mathrm{~N}$-legume leaf material or a mixture using enriched urea ${ }^{15} \mathrm{~N}$ fertilizer. Soil as control was only treated with urea ${ }^{14} \mathrm{~N}$ fertilizer. Bars represent standard error of the mean.

In the S. paniculatum and I. edulis treatments, which had initially relatively higher amounts of added leaf biomass in comparison with the previous experiment (Section 3.3.2.1), no significant increase in total rice $\mathrm{N}$ content compared to pots which received no residues was observed, suggesting that these pots were not $\mathrm{N}$ limited.

\subsubsection{Nitrogen recovery by rice}

The increase in recovery of total $-\left({ }^{14} \mathrm{~N}+{ }^{15} \mathrm{~N}\right)$ and $-{ }^{15} \mathrm{~N}$ by rice showed contrasting patterns for the different treatments (Figure 26). The legume mixture led to, a higher recovery of total$\left({ }^{14} \mathrm{~N}+{ }^{15} \mathrm{~N}\right)$ and a higher recovery of ${ }^{15} \mathrm{~N}$ than with the two separate legume species. Initial recovery of ${ }^{15} \mathrm{~N}$ from rice did not differ significantly $(\mathrm{P}>0.05)$ between the two legume treatments. 

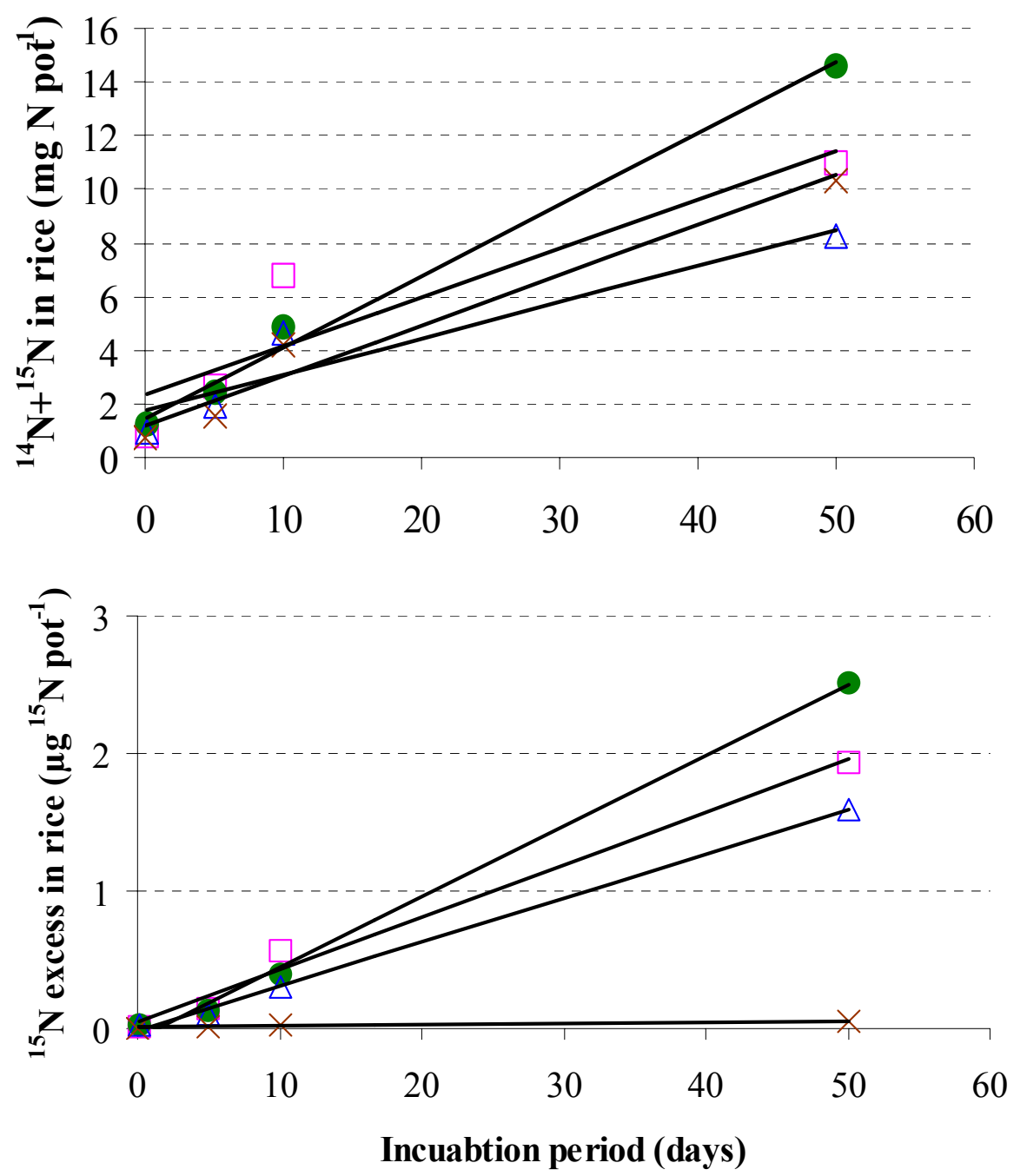

$\square$ I. edulis $\quad \mathrm{p}^{*} \mathrm{e} \quad \triangle \mathrm{S}$. paniculatum $\quad \times$ Control

Figure 26. ${ }^{14} \mathrm{~N}+{ }^{15} \mathrm{~N}$ recovery and ${ }^{15} \mathrm{~N}$ in rice for treatment of soil with ${ }^{15} \mathrm{~N}$-leaf material of two different legumes species and species mixture and ${ }^{14} \mathrm{~N}$-urea fertilizer in comparison with soil without added leaf material and fertilized with ${ }^{15} \mathrm{~N}$-urea, for different incubation periods. The ${ }^{15} \mathrm{~N}$ is expressed as the atom $\%{ }^{15} \mathrm{~N}$ excess abundance above the background $(0.3663$ atom \%).

\subsubsection{Nitrogen concentration in rice}

The $\mathrm{N}$ concentration in rice increased until 10 days after transplanting (Table 28) and, during this phase of rice growth, the legume treatments did not differ from the control $(\mathrm{P}>0.05)$. At the end of the incubation period, S. paniculatum showed a significantly $(\mathrm{P}<0.01)$ lower $\mathrm{N}$ final concentration in rice (11.6) in comparison with the control (17.4 $\mathrm{mg} \mathrm{N} \mathrm{g}^{-1}$ dry matter), $I$. edulis (18.0 $\mathrm{mg} \mathrm{N} \mathrm{g}^{-1}$ dry matter) and $\mathrm{p}^{*} \mathrm{e}$ mixture (18.2 $\mathrm{mg} \mathrm{N} \mathrm{g}^{-1}$ dry matter). 
The $\mathrm{p}^{*}$ e mixture treatment presented a higher $\mathrm{N}$ concentration in rice (Table 28 ) in comparison with the I. edulis, control and S. paniculatum treatment. However, S. paniculatum treatment did not differ statistically from control and I. edulis treatment.

Table 28. Nitrogen concentration ( $\mathrm{mg} \mathrm{N} \mathrm{g}^{-1}$ dry matter) for different treatment and control during the incubation time (days). Control was soil without added leaf material and fertilized with N-urea.

\begin{tabular}{|c|c|c|c|c|}
\hline \multirow{2}{*}{$\begin{array}{l}\text { Treatment / Incubation } \\
\text { period (days) }\end{array}$} & \multicolumn{4}{|c|}{$\mathrm{N}$ concentration ( $\mathrm{mg} \mathrm{N} \mathrm{g}^{-1}$ rice dry matter) } \\
\hline & 0 & 5 & 10 & 50 \\
\hline S. paniculatum & 11.2 & 18.0 & 25.3 & 11.6 \\
\hline $\mathrm{p}^{* \mathrm{e}}$ & 14.3 & 19.2 & 27.8 & 18.2 \\
\hline I. edulis & 14.2 & 19.6 & 30.4 & 18.0 \\
\hline Control & 11.6 & 23.4 & 31.7 & 17.4 \\
\hline LSD & $3.17^{\mathrm{NS}}$ & $1.54^{*}$ & $6.40^{\mathrm{NS}}$ & $6.45^{*}$ \\
\hline
\end{tabular}

LSD compares different treatment at the same sampling time; ${ }^{\mathrm{NS}}$ is not significant; ${ }^{*}=\mathrm{P}<0.05$

\subsubsection{Nitrogen derived from residue (Ndfr) and nitrogen recovered from residue (Nrfr)}

Nitrogen derived from residues of different ${ }^{15} \mathrm{~N}$-legume leaf material was not statistically different between treatments until five days of incubation (Table 29). At ten days, a significantly higher amount of total $\mathrm{N}$ in rice came from the I. edulis $(34.1 \%)$ and $\mathrm{p}^{*} \mathrm{e}$ mixture (31.9\%) than from the S. paniculatum (25.2\%). However, at the end of the incubation period, $\mathrm{N}$ in rice originating from the $S$. paniculatum leaf material increased by $11.4 \%$ in comparison with a decrease of $3.4 \%$ and $2.5 \%$ for the $\mathrm{p}^{*} \mathrm{e}$ mixture and $I$. edulis treatments, respectively, reflecting the lower biodegradability of S. paniculatum. 
Table 29. Nitrogen derived from residue (NdfR) in $\%$ and $\mathrm{mg}$, and $\mathrm{N}$ recovered from residue $(\mathrm{NrfR}, \%)$ during the greenhouse incubation period in soil treated with ${ }^{15} \mathrm{~N}$-leaf legume and ${ }^{14} \mathrm{~N}$-urea fertilizer.

\begin{tabular}{|c|c|c|c|c|}
\hline \multicolumn{5}{|c|}{$\mathrm{N}$ derived from residue $(\mathrm{Ndfr}, \%)$} \\
\hline \multirow[t]{2}{*}{ Treatment } & \multicolumn{4}{|c|}{ Incubation period (days) } \\
\hline & 0 & 5 & 10 & 50 \\
\hline S. paniculatum & 8.62 & 21.5 & 25.2 & 36.2 \\
\hline $\mathrm{p}^{*} \mathrm{e}$ & 8.87 & 21.7 & 31.9 & 28.6 \\
\hline \multirow[t]{2}{*}{ I. edulis } & 7.66 & 22.4 & 34.1 & 31.6 \\
\hline & $1.21^{\mathrm{NS}}$ & $0.92^{\mathrm{NS}}$ & $2.18^{* *}$ & $0.66^{* *}$ \\
\hline \multicolumn{5}{|c|}{$\mathrm{N}$ derived from residue ( $\mathrm{Ndfr}, \mathrm{mg})$} \\
\hline S. paniculatum & 0.08 & 0.42 & 1.17 & 2.99 \\
\hline $\mathrm{p}^{*} \mathrm{e}$ & 0.11 & 0.52 & 1.55 & 4.18 \\
\hline \multirow[t]{2}{*}{ I. edulis } & 0.06 & 0.60 & 2.31 & 3.45 \\
\hline & $0.03^{*}$ & $0.07^{* *}$ & $0.10^{* *}$ & $0.73^{*}$ \\
\hline \multicolumn{5}{|c|}{$\mathrm{N}$ recovered from residue $(\mathrm{Nrfr}, \%)$} \\
\hline S. paniculatum & 0.10 & 0.51 & 1.45 & 3.68 \\
\hline $\mathrm{p}^{*} \mathrm{e}$ & 0.14 & 0.64 & 1.91 & 5.16 \\
\hline I. edulis & 0.08 & 0.75 & 2.90 & 4.32 \\
\hline LSD & $0.03^{*}$ & $0.03^{* *}$ & $0.13^{* *}$ & $0.84^{*}$ \\
\hline
\end{tabular}

LSD compares different treatment at the same sampling time; ${ }^{\mathrm{NS}}$ is not significant; ${ }^{*}=\mathrm{P}<0.05 ;{ }^{* *}=\mathrm{P}$ $<0.01 ;{ }^{* * *}=\mathrm{P}<0.001$.

The amount of $\mathrm{N}$ derived from residues increased significantly for all treatments during the incubation period (Table 29). The higher increase in $\mathrm{N}$ recovered from the added leaf material was found in the $\mathrm{p}^{*}$ e mixture treatment, which showed an increase of $4.07 \mathrm{mg} \mathrm{N}$ in comparison with 3.39 and $2.91 \mathrm{mg} \mathrm{N}$ for the I. edulis and S. paniculatum treatments, respectively.

With this higher increase, the total $\mathrm{N}$ recovered from added legume leaf material was significantly higher for the $\mathrm{p}^{*}$ e mixture than the other treatments (Table 29). However, for the first 10 days of the incubation period, the I. edulis treatment showed the higher percentage 
$(3.65 \%)$ of total $\mathrm{N}$ recovered from the added leaf material in comparison with the $\mathrm{p}^{*} \mathrm{e}$ mixture $(2.55 \%)$ and $S$. paniculatum treatments $(1.96 \%)$.

Lower rates of ${ }^{15} \mathrm{~N}$-recovery could be due to mineralization-immobilization turnover (Thönnissen et al. 2000). The ${ }^{15} \mathrm{~N}$-release from the legume residue into the soil inorganic pool could be exchanged for ${ }^{14} \mathrm{~N}$ in microbial biomass, which could lead to a lower ${ }^{15} \mathrm{~N}$-recovery. On the other hand, lower rates for ${ }^{15} \mathrm{~N}$ recovery than for total $\mathrm{N}$ may result partly from an overestimation of apparent total $\mathrm{N}$ recovery and partly from the importance of soil conditions, in terms of C-quality, during the rapid degradation of ${ }^{15} \mathrm{~N}$-labeled material.

\subsubsection{5 $\mathrm{NH}_{4}^{+}-\mathrm{N}$ and $\mathrm{NO}_{3}^{-}-\mathrm{N}$ concentration and microbial immobilization in soil}

\subsection{Soil $\mathrm{NH}_{4}{ }^{+}-{ }^{14} \mathrm{~N}$ and $-{ }^{15} \mathrm{~N}$ concentration}

In the same way that was shown for the other experiment (Section 3.3.2.5), all treatments exhibited a strong decrease in total $\mathrm{NH}_{4}{ }^{+}-\left({ }^{14} \mathrm{~N}+{ }^{15} \mathrm{~N}\right)$ and excess $\mathrm{NH}_{4}{ }^{+}-{ }^{15} \mathrm{~N}$ in the soil during the incubation period (Table 30). The higher proportional decrease in the $\mathrm{NH}_{4}{ }^{+}-\left({ }^{14} \mathrm{~N}+{ }^{15} \mathrm{~N}\right)$ concentration was found in the control treatment (98.2\% of initial concentration), followed by the S. paniculatum treatment (97.2\%), I. edulis treatment (96.5\%) and $\mathrm{p}^{*}$ e mixture treatments $(94.6 \%)$. This confirms that the competition between rice and microorganisms was very intensive in all treatments.

The significant differences in $\mathrm{NH}_{4}{ }^{+}-\left({ }^{14} \mathrm{~N}+{ }^{15} \mathrm{~N}\right)$ found at time 0 suggest that the I. edulis and $S$. paniculatum treatments were subject to a more rapid initial decomposition in comparison with the $\mathrm{p}^{*} \mathrm{e}$ mixture during the pre-incubation period. However, the $\mathrm{p}^{*} \mathrm{e}$ mixture treatment displayed a higher initial $\mathrm{N}$ immobilization by soil microbial biomass, which will be discussed below.

If the rice absorption was the same for all treatments, the slower decrease in $\mathrm{NH}_{4}{ }^{+}-\mathrm{N}$ concentration for the $\mathrm{p}^{*} \mathrm{e}$ mixture during the first 10 days of the incubation period would mean a significantly $(\mathrm{P}<0.01)$ lower $\mathrm{N}$ immobilization off-setting a higher $\mathrm{N}$-mineralization from organic amended for this treatment in comparison with the single legume treatment. 
Table 30. Total $\mathrm{NH}_{4}{ }^{+}-\left({ }^{14} \mathrm{~N}+{ }^{15} \mathrm{~N}\right)\left(\mu \mathrm{g} \mathrm{N} \mathrm{g}{ }^{-1}\right.$ soil $)$ and excess $\mathrm{NH}_{4}{ }^{+}-{ }^{15} \mathrm{~N}\left(\mu \mathrm{g}{ }^{15} \mathrm{~N} \mathrm{~g}^{-1}\right.$ soil $)$ in soil amended with different ${ }^{15} \mathrm{~N}$-leaf legume material and ${ }^{14} \mathrm{~N}$-urea as fertilizer with rice as an indicator plant. Control soil as was only fertilized with ${ }^{14} \mathrm{~N}$-urea. The ${ }^{15} \mathrm{~N}$ excess is expressed as the atom $\%{ }^{15} \mathrm{~N}$ excess abundance above the background $(0.3663$ atom $\%)$.

\begin{tabular}{|c|c|c|c|c|}
\hline \multicolumn{5}{|l|}{$\mathrm{NH}_{4}{ }^{+}-\left({ }^{14} \mathrm{~N}+{ }^{15} \mathrm{~N}\right)$} \\
\hline \multirow[b]{2}{*}{ Treatment } & \multicolumn{4}{|c|}{ Incubation period (days) } \\
\hline & 0 & 5 & 10 & 50 \\
\hline S. paniculatum & $24.1^{\mathrm{ab}}$ & 14.0 & $3.0^{\mathrm{b}}$ & $0.68^{\mathrm{ab}}$ \\
\hline $\mathrm{p}^{*} \mathrm{e}$ & $18.2^{b}$ & 12.4 & $11.9^{\mathrm{a}}$ & $0.99^{\mathrm{ab}}$ \\
\hline I. edulis & $36.5^{\mathrm{a}}$ & 15.6 & $2.9^{\mathrm{b}}$ & $1.27^{\mathrm{a}}$ \\
\hline Control & $10.0^{\mathrm{b}}$ & 12.3 & $10.6^{\mathrm{a}}$ & $0.18^{\mathrm{b}}$ \\
\hline LSD & $14.07^{*}$ & $3.24^{\mathrm{NS}}$ & $1.25^{* * *}$ & $0.81^{*}$ \\
\hline \multicolumn{5}{|l|}{$\mathrm{NH}_{4}{ }^{+}-{ }^{15} \mathrm{~N}$ excess } \\
\hline S. paniculatum & 0.0061 & $0.0022^{\mathrm{a}}$ & $0.0004^{\mathrm{ab}}$ & $0.00003^{b}$ \\
\hline $\mathrm{p}^{*} \mathrm{e}$ & 0.0014 & $0.0022^{\mathrm{a}}$ & $0.0014^{\mathrm{a}}$ & $0.00006^{\mathrm{a}}$ \\
\hline I. edulis & 0.0036 & $0.0024^{\mathrm{a}}$ & $0.0006^{\mathrm{ab}}$ & $0.00005^{\mathrm{ab}}$ \\
\hline Control & 0.0001 & $0.0001^{\mathrm{b}}$ & $0.0002^{\mathrm{b}}$ & $0.00000^{\mathrm{c}}$ \\
\hline LSD & $0.0060^{\mathrm{NS}}$ & $0.0002^{* * *}$ & $0.0080^{*}$ & $0.00003^{* *}$ \\
\hline
\end{tabular}

LSD compares different treatments at the same sampling time; ${ }^{\text {NS }}$ is not significant; ${ }^{*}=\mathrm{P}<0.05 ;{ }^{* *}=\mathrm{P}$ $<0.01 ;^{* * *}=\mathrm{P}<0.001$.

The excess $\mathrm{NH}_{4}{ }^{+}-{ }^{15} \mathrm{~N}$ derived from leaf material showed that the $\mathrm{p}^{*} \mathrm{e}$ mixture had an initially low mineralization and a significantly higher increase in the course of the incubation period (Table 30). Similar to $\mathrm{NH}_{4}{ }^{+}-\left({ }^{14} \mathrm{~N}+{ }^{15} \mathrm{~N}\right)$, the decrease in the soil $\mathrm{NH}_{4}{ }^{+}-{ }^{15} \mathrm{~N}$ concentration was lower for the $\mathrm{p}^{*} \mathrm{e}$ mixture treatment.

\subsection{Soil $\mathrm{NO}_{3^{-}}{ }^{14} \mathrm{~N}$ and ${ }^{-15} \mathrm{~N}$ concentration}

The initial $\mathrm{NO}_{3}{ }^{-} \mathrm{N}$ concentration in the soil was significantly higher for the $S$. paniculatum treatment in comparison with I. edulis and control (Table 31). All treatments showed a significant $(\mathrm{P}<0.05)$ decrease in the $\mathrm{NO}_{3}{ }^{-}-\mathrm{N}$ concentration during the incubation period. The decrease in the $\mathrm{NO}_{3}{ }^{-} \mathrm{N}$ concentration was higher for the $\mathrm{p}^{*}$ e mixture $(69.6 \%$ of initial concentration), followed by S. paniculatum (67.1\%), in comparison with the I. edulis $(60.3 \%)$ 
and control (21.8\%). In this experiment, only the control showed an initial increase in the $\mathrm{NO}_{3}{ }^{-}-\mathrm{N}$ concentration during the initial incubation period (0-5 days).

Table 31. Total $\mathrm{NO}_{3}{ }^{-}-\mathrm{N}\left(\mu \mathrm{g} \mathrm{N} \mathrm{g}\right.$ soil) and excess $\mathrm{NO}_{3}{ }^{-}{ }^{-15} \mathrm{~N}\left(\mu \mathrm{g}{ }^{15} \mathrm{~N} \mathrm{~g}^{-1}\right.$ soil $)$ in soil amended with different ${ }^{15} \mathrm{~N}$-leaf legume material and ${ }^{14} \mathrm{~N}$-urea as fertilizer with rice as an indicator plant. Control was soil without added leaf material and fertilized with $\mathrm{N}$-urea. The ${ }^{15} \mathrm{~N}$ excess is expressed as the atom $\%{ }^{15} \mathrm{~N}$ excess abundance above the background $(0.3663$ atom \%).

\begin{tabular}{lccc}
\hline $\mathrm{NO}_{3}{ }^{-}-\left({ }^{14} \mathrm{~N}+{ }^{15} \mathrm{~N}\right)$ & \multicolumn{3}{c}{ Incubation period (days) } \\
\hline Treatment & 0 & 10 & 50 \\
\cline { 2 - 4 } S. paniculatum & $3.04^{\mathrm{a}}$ & $1.56^{\mathrm{ab}}$ & 1.00 \\
$\mathrm{p}^{*} \mathrm{e}$ & $2.50^{\mathrm{ab}}$ & $1.29^{\mathrm{ab}}$ & 0.76 \\
I. edulis & $1.79^{\mathrm{bc}}$ & $0.97^{\mathrm{b}}$ & 0.71 \\
Control & $1.10^{\mathrm{c}}$ & $1.80^{\mathrm{a}}$ & 0.86 \\
\cline { 2 - 4 }$\quad$ & $0.72^{* *}$ & $0.59^{*}$ & $0.04^{\mathrm{NS}}$ \\
\hline $\mathrm{NO}_{3}{ }^{-15} \mathrm{~N}$ & & & \\
\hline S. paniculatum & $0.00041^{\mathrm{a}}$ & $0.00014^{\mathrm{a}}$ & $0.00008^{\mathrm{a}}$ \\
$\mathrm{p}^{*} \mathrm{e}$ & $0.00026^{\mathrm{b}}$ & $0.00006^{\mathrm{ab}}$ & $0.00007^{\mathrm{a}}$ \\
I. edulis & $0.00019^{\mathrm{b}}$ & $0.00012^{\mathrm{a}}$ & $0.00004^{\mathrm{ab}}$ \\
Control & $0.00000^{\mathrm{c}}$ & $0.00001^{\mathrm{b}}$ & $0.00001^{\mathrm{b}}$ \\
\cline { 2 - 4 }$\quad$ LSD & $0.00140^{* * *}$ & $0.00007^{*}$ & $0.00004^{*}$
\end{tabular}

LSD compares different treatments at the same sampling time; ${ }^{\mathrm{NS}}$ is not significant; ${ }^{*}=\mathrm{P}<0.05 ;{ }^{* *}=\mathrm{P}$ $<0.01 ;{ }^{* * *}=\mathrm{P}<0.001$.

The concentration of excess $\mathrm{NO}_{3}{ }^{-15} \mathrm{~N}$ was significantly lower for the control in comparison with the legume treatments (Table 31). These data suggest that the enriched ${ }^{15} \mathrm{~N}$ in the legume material was mineralized more rapidly and subsequently nitrified.

\subsection{Soil microbial biomass $-{ }^{14} \mathrm{~N}$ and $-{ }^{15} \mathrm{~N}$}

A high $\left({ }^{14} \mathrm{~N}+{ }^{15} \mathrm{~N}\right)$-microbial biomass was observed at the beginning of the greenhouse experiment for the $\mathrm{p}^{*}$ e mixture (Table 32) in comparison to the other treatments. All treatments showed an increase in $\mathrm{N}$ absorption from microorganisms during the first five days. This increase was very high for the I. edulis treatment, which showed an increase of 
$500 \%$ of the initial concentration, followed by the $\mathrm{p}^{*}$ e mixture $(27 \%)$, S. paniculatum $(10 . \%)$ and control $(8.8 \%)$.

Table 32. $\left({ }^{14} \mathrm{~N}+{ }^{15} \mathrm{~N}\right)$-microbial biomass $\left(\mu \mathrm{g}{ }^{14} \mathrm{~N}+{ }^{15} \mathrm{Ng}^{-1}\right.$ soil $)$ and ${ }^{15} \mathrm{~N}$-microbial biomass $(\mu \mathrm{g}$ ${ }^{15} \mathrm{~N}$ excess $\mathrm{g}^{-1}$ soil) in soil amended with ${ }^{14} \mathrm{~N}$-legume leaf material and enriched ${ }^{15} \mathrm{~N}$-urea fertilizer with rice as an indicator plant. Control was soil without added leaf material and fertilized with $\mathrm{N}$-urea. The ${ }^{15} \mathrm{~N}$ excess is expressed as the atom $\%{ }^{15} \mathrm{~N}$ excess abundance above the background ( 0.3663 atom \%).

\begin{tabular}{|c|c|c|c|c|}
\hline \multicolumn{5}{|c|}{$\left({ }^{14} \mathrm{~N}+{ }^{15} \mathrm{~N}\right)$-microbial biomass $\left(\mu \mathrm{g}{ }^{14} \mathrm{~N}+{ }^{15} \mathrm{Ng}^{-1}\right.$ soil $)$} \\
\hline \multirow{2}{*}{ Treatment } & \multicolumn{4}{|c|}{ Incubation period (days) } \\
\hline & 0 & 5 & 10 & 50 \\
\hline S. paniculatum & $3.8^{\mathrm{b}}$ & $4.2^{\mathrm{c}}$ & $5.1^{\mathrm{c}}$ & $5.5^{\mathrm{a}}$ \\
\hline $\mathrm{p}^{*} \mathrm{e}$ & $12.9^{\mathrm{a}}$ & $16.4^{\mathrm{b}}$ & $14.1^{\mathrm{b}}$ & $2.8^{\mathrm{b}}$ \\
\hline I. edulis & $3.2^{\mathrm{b}}$ & $19.3^{\mathrm{a}}$ & $17.5^{\mathrm{a}}$ & $1.3^{\mathrm{c}}$ \\
\hline Control & $4.7^{\mathrm{b}}$ & $5.1^{\mathrm{c}}$ & $2.7^{\mathrm{d}}$ & $1.0^{\mathrm{c}}$ \\
\hline LSD & $1.451^{* * *}$ & $0.915^{* * *}$ & $0.310^{* * *}$ & $0.298^{* * *}$ \\
\hline \multicolumn{5}{|c|}{${ }^{15} \mathrm{~N}$-microbial biomass $\left(\mu \mathrm{g}{ }^{15} \mathrm{~N}\right.$ excess $\mathrm{g}^{-1}$ soil $)$} \\
\hline S. paniculatum & $0.01618^{\mathrm{a}}$ & $0.00084^{b}$ & $0.00134^{\mathrm{a}}$ & $0.00041^{\mathrm{a}}$ \\
\hline $\mathrm{p}^{*} \mathrm{e}$ & $0.00180^{\mathrm{b}}$ & $0.00316^{\mathrm{a}}$ & $0.00369^{\mathrm{a}}$ & $0.00021^{\mathrm{ab}}$ \\
\hline I. edulis & $0.00123^{\mathrm{b}}$ & $0.00308^{\mathrm{a}}$ & $0.00314^{\mathrm{a}}$ & $0.00026^{\mathrm{ab}}$ \\
\hline Control & $0.00002^{\mathrm{c}}$ & $0.00004^{\mathrm{c}}$ & $0.00001^{b}$ & $0.00001^{\mathrm{b}}$ \\
\hline LSD & $0.0018^{* * *}$ & $0.00070^{* *}$ & $0.00307^{*}$ & $0.00025^{*}$ \\
\hline
\end{tabular}

LSD compares treatment at the same sampling time; ${ }^{*}=\mathrm{P}<0.05 ;{ }^{* *}=\mathrm{P}<0.01 ;{ }^{* * *}=\mathrm{P}<0.001$.

The high N-microbial biomass level remained high in the I. edulis and $\mathrm{p}^{*} \mathrm{e}$ mixture treatments for the first 10 days of the greenhouse experiment (Table 32). However, at the end of the incubation period, these treatments showed a significantly higher decrease in the microbial biomass- $\left({ }^{14} \mathrm{~N}+{ }^{15} \mathrm{~N}\right)$, whereas the $S$. paniculatum treatment displayed a significantly high increase in the concentration of ${ }^{14} \mathrm{~N}+{ }^{15} \mathrm{~N}$ in the microbial biomass.

In all treatments, a significantly higher microbial biomass $-{ }^{15} \mathrm{~N}$ was observed during the first 10 days of the incubation period in comparison with the control (Table 32). The initially higher microbial biomass- ${ }^{15} \mathrm{~N}$ concentration for the S. paniculatum treatment indicated 
intensive microbial activity leading to decomposition of recalcitrant leaf material in this treatment. However, after fertilizer had been added, the ${ }^{15} \mathrm{~N}$-excess immobilization in the soil increased to $155 \%$ of the initial concentration in the I. edulis treatment and $105 \%$ in the $\mathrm{p}^{*} \mathrm{e}$ mixture treatment, whereas the S. paniculatum treatment showed a decrease of $92 \%$ in the microbial biomass- ${ }^{15} \mathrm{~N}$ concentration. At the end of the experiment, all legume treatments showed a significant decrease in the microbial biomass- ${ }^{15} \mathrm{~N}$, and only the S. paniculatum showed a significantly higher microbial ${ }^{15} \mathrm{~N}$-concentration in comparison with control (Table $32)$.

The decrease in soil mineral nitrogen over time was attributable not only to rice plant uptake, but also to considerable microbial immobilization. The use of a mixture of two contrasting litter qualities (called $\mathrm{p}^{*} \mathrm{e}$ mixture) improved the nitrogen recovered by rice, which was derived from urea-fertilizer by $35.1 \%$ and $41.3 \%$ of total fertilized $\mathrm{N}$ in comparison with $S$. paniculatum and I. edulis treatments, respectively. In the same way, the rice recovery of $\mathrm{N}$ derived from the legume material in the p*e mixture improved by $73.3 \%$ compared with the $S$. paniculatum treatment, but was $0.9 \%$ lower than that of the I. edulis treatment.

Moreover, the use of a larger amount of leaf material resulted in a higher increase in $\mathrm{N}$ immobilization and mineral-N in the soil, depending on the quality of the leaf material. The total cumulative nitrogen mineralization increased $90.9 \%, 10.3 \%$, and $18.8 \%$ for the $S$. paniculatum, $\mathrm{p}^{*} \mathrm{e}$ mixture and I. edulis treatments, respectively. In the same way, the increases in cumulative microbial biomass-N during the incubation period were $109 \%, 190 \%$ and $344 \%$, respectively.

The $\mathrm{p}^{*} \mathrm{e}$ mixture treatment showed an intermediate cumulative soil microbial- ${ }^{15} \mathrm{~N}$ immobilization, higher cumulative rice biomass and total $\mathrm{N}$, and higher recovery of ${ }^{15} \mathrm{~N}$ from urea fertilizer. This indicates that the interaction of two different leguminous species increases the nitrogen absorption by rice through the increase in mineral-N and the decrease of gross microbial-N immobilization.

\subsection{Field experiment}

\subsubsection{Litter quality}

The species included in this study showed contrasting nutrient concentrations (Table 3). The control, S. paniculatum and A. angustissima had the highest initial N concentrations, whereas A. mangium had the lowest. The highest $\mathrm{C}$-to-N ratio was found for $A$. mangium and intermediate ratios for C. racemosa, A. angustissima and I. edulis. Because all treatments had 
initial C-to-N ratios of more than 40, an initial net $\mathrm{N}$ immobilization was to be expected (Stevenson and Cole 1999). The highest initial concentrations of $\mathrm{P}$ were found in $A$. angustissima and I. edulis, and the lowest in S. paniculatum and A. mangium.

Table 33. Initial chemical composition of litter bag material from different leguminous species and control (natural fallow vegetation) used in the decomposition experiment at Igarapé-Açú, Brazil.

\begin{tabular}{|c|c|c|c|c|c|c|c|c|c|c|}
\hline \multirow{2}{*}{ Species } & $\mathrm{N}$ & $\mathrm{C}$ & \multirow[t]{2}{*}{$\mathrm{C} / \mathrm{N}$} & $\mathrm{P}$ & K & $\mathrm{Ca}$ & $\mathrm{Mg}$ & Lignin & Cellulose & Phenol \\
\hline & \multicolumn{2}{|c|}{$\mathrm{g} \mathrm{kg}^{-1}$} & & \multicolumn{4}{|c|}{$\mathrm{g} \mathrm{kg}^{-1}$} & \multicolumn{3}{|c|}{$\%$} \\
\hline A. angustissima & 8.3 & 511 & 61.5 & 0.77 & 13.3 & 6.5 & 2.6 & 18.3 & 54.0 & 29.7 \\
\hline Fallow (control) & 10.1 & 475 & 47.0 & 0.41 & 5.3 & 9.6 & 1.6 & 28.5 & 41.4 & 10.8 \\
\hline I. edulis & 7.2 & 495 & 68.7 & 0.74 & 13.5 & 11.0 & 2.7 & 31.4 & 44.1 & 20.6 \\
\hline A. mangium & 5.0 & 497 & 99.3 & 0.31 & 6.7 & 11.1 & 2.9 & 26.5 & 46.9 & 19.1 \\
\hline C. racemosa & 7.8 & 483 & 61.9 & 0.68 & 11.6 & 7.9 & 2.6 & 23.8 & 44.6 & 11.6 \\
\hline S. paniculatum & 8.6 & 458 & 53.3 & 0.39 & 5.9 & 8.8 & 1.7 & 29.5 & 41.8 & 11.3 \\
\hline
\end{tabular}

S. paniculatum and the control fallow showed the highest initial concentrations of $K$ and $M g$ (Table 3). I. edulis contained high levels of $M g$, lignin. A. angustissima showed a high concentration of phenol. A. angustissima and C. racemosa, were low in lignin while the fallow control, S. paniculatum and C. racemosa were low in phenol.

\subsubsection{Field decomposition}

A rapid decrease in ash-free dry matter was observed with $C$. racemosa and A. mangium material in comparison with other treatments (Figure 27). A. mangium had a faster weight loss in the first week of the experiment, but later this was slower than that of the C. racemosa. No significant differences $(\mathrm{P}>0.05)$ in decomposition rates were observed between $A$. angustissima, S. paniculatum, I. edulis, and the fallow control. 


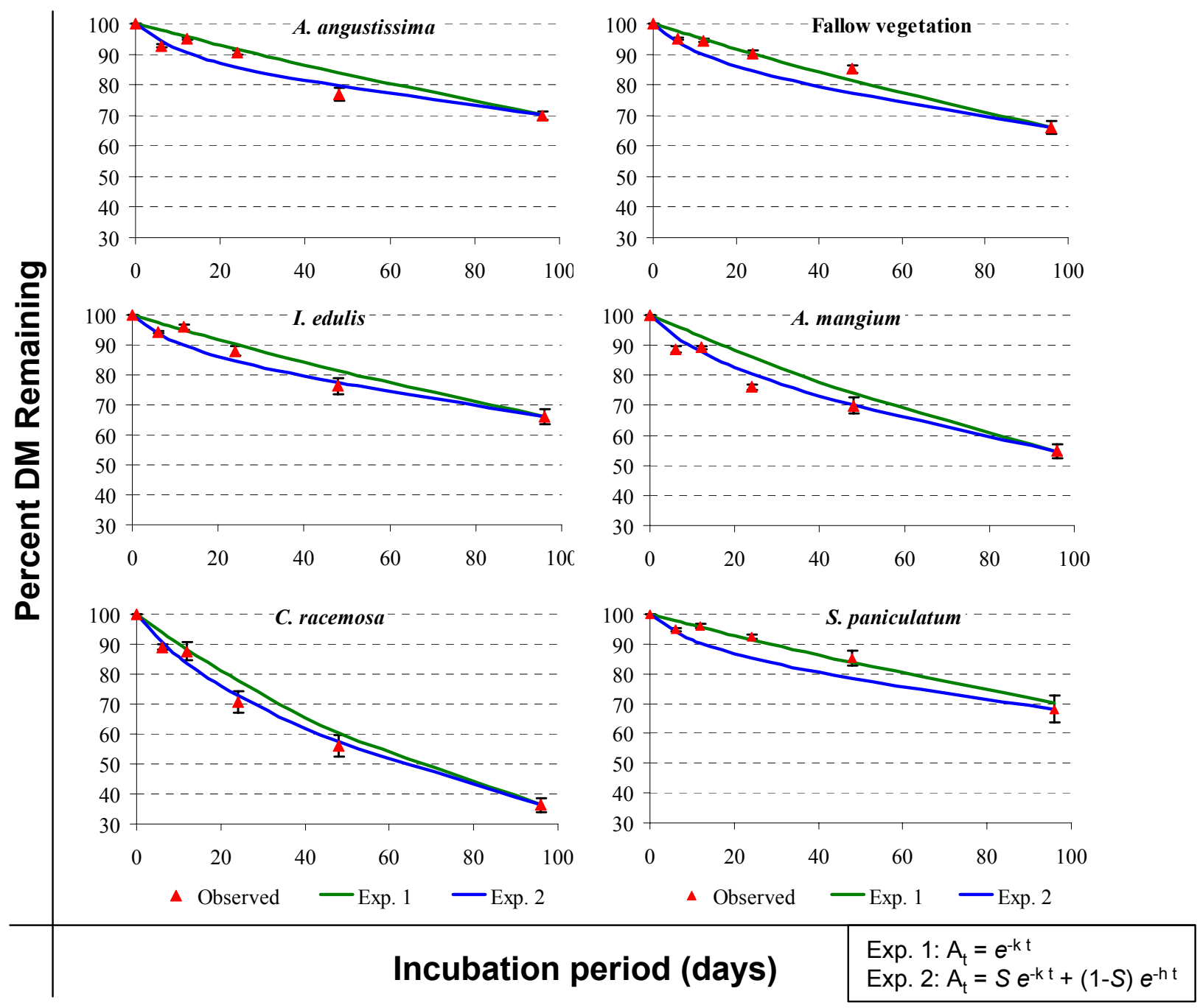

Figure 27. Observed (points) and fitted (lines) decomposition curves for five-legume species and fallow vegetation (as control). Bars represent Standard error of the mean. Exp. 1 (Equation 15) and 2 (Equation 16) means single and double exponential model, respectively.

After 96 days of decomposition, weight loss was $30.1 \%$ for $A$. angustissima, $32.7 \%$ for $S$. paniculatum, $33.9 \%$ for I. edulis and control, $45.2 \%$ for $A$. mangium and $63.6 \%$ for $C$. racemosa (Figure 27). Weight losses for C. racemosa and A. mangium were significantly greater $(\mathrm{n}=9 ; \mathrm{P}<0.001)$ than for the other three leguminous species and the fallow control, which showed a similar $\mathrm{k}$ and $\mathrm{h}$ value (Table 4).

Generally, the best curve fit of litter decomposition was obtained by using the double exponential model, giving the better correlation coefficient for the majority of the treatments. However, for the control and S. paniculatum, the single exponential model gave a better fit. No significant differences were found between the two models for A. angustissima and $I$. edulis $(\mathrm{P}>0.05)$. During the first week, when high loss of leaf material was to be expected, 
the litter decomposition for all treatments was best characterized by a double exponential curve (two-pool model, Figure 27).

The exponential weight loss pattern agrees with previous assumption that residues contain labile and recalcitrant fractions having different degrees of resistance to microbial degradation. Reinertsen et al. (1984) associated the more rapid decay immediately after the burial of the residue with the decomposition of water-soluble organic contents. Hunt et al. (1988) described differences in decomposition patterns and rates among substrates as a function of the amount the labile or rapidly decomposing fractions (sugar, starches, proteins) and the recalcitrant or slowly decomposing fraction (cellulose, lignin, fats, tannins, and waxes).

Table 34. Estimated values of parameters of decomposition model (Equation 3) fitted to data of different leguminous species.

\begin{tabular}{llll}
\hline \multirow{2}{*}{ Species } & \multicolumn{3}{c}{ Simultaneous estimates } \\
\cline { 2 - 4 } & $S$ & $K$ & $h$ \\
\hline S. paniculatum & 0.1000 & 0.0894 & 0.0029 \\
Fallow (control) & 0.0997 & 0.0910 & 0.0032 \\
I. edulis & 0.0997 & 0.0909 & 0.0032 \\
A. angustissima & 0.0997 & 0.0917 & 0.0026 \\
A. mangium & 0.0996 & 0.0911 & 0.0052 \\
C. racemosa & 0.0997 & 0.0920 & 0.0094
\end{tabular}

Where $S$ is initial proportion of labile material; $k$ is the rate constant for the labile component; $h$ is the rate constant for the resistant component

The comparison of litter decomposition exposed on top of bare soil (-OM) or buried below mulch $(+O M)$ revealed different patterns of decomposition (Table 35). A. mangium, $C$. racemosa, fallow control and $S$. paniculatum showed significantly higher biomass losses when exposed -OM than when buried $+O M$. But I. edulis and A. angustissima were not significantly affected. 
Table 35. The proportion of remaining material (\%) at different sampling times (days) for 5 leguminous species and the control (fallow vegetation) as affected by placing on bare soil ($\mathrm{OM})$ and burying below a thick mulch layer (+OM).

\begin{tabular}{|c|c|c|c|c|c|c|}
\hline \multirow{2}{*}{ Species } & \multirow{2}{*}{ Status } & \multicolumn{5}{|c|}{ Sampling time (days) } \\
\hline & & 6 & 12 & 24 & 48 & 96 \\
\hline \multirow[t]{3}{*}{ A. angustissima } & $-\mathrm{OM}$ & 97.6 & 90.2 & 96.1 & 89.7 & 73.1 \\
\hline & $+\mathrm{OM}$ & 92.7 & 95.1 & 90.5 & 77.0 & 69.9 \\
\hline & LSD & NS & * & NS & $* * *$ & NS \\
\hline \multirow[t]{3}{*}{ Fallow (control) } & $-\mathrm{OM}$ & 99.8 & 86.5 & 68.6 & 65.4 & 48.1 \\
\hline & $+\mathrm{OM}$ & 95.1 & 94.5 & 90.4 & 85.2 & 66.1 \\
\hline & LSD & NS & * & $* * *$ & $* * *$ & $* * *$ \\
\hline \multirow[t]{3}{*}{ I. edulis } & $-\mathrm{OM}$ & 96.3 & 90.1 & 74.4 & 78.3 & 71.1 \\
\hline & $+\mathrm{OM}$ & 94.2 & 96.0 & 88.0 & 76.4 & 66.1 \\
\hline & LSD & NS & * & $* * *$ & NS & NS \\
\hline \multirow[t]{3}{*}{ A. mangium } & $-\mathrm{OM}$ & 96.7 & 84.4 & 77.7 & 53.2 & 26.4 \\
\hline & $+\mathrm{OM}$ & 88.6 & 89.2 & 76.1 & 69.9 & 54.8 \\
\hline & LSD & * & NS & NS & $* * *$ & $* * *$ \\
\hline \multirow[t]{3}{*}{ C. racemosa } & $-\mathrm{OM}$ & 85.6 & 87.7 & 78.2 & 55.8 & 13.4 \\
\hline & $+\mathrm{OM}$ & 89.0 & 87.6 & 70.8 & 56.2 & 36.4 \\
\hline & LSD & NS & NS & NS & NS & $* * *$ \\
\hline \multirow[t]{3}{*}{ S. paniculatum } & $-\mathrm{OM}$ & 93.6 & 87.9 & 84.7 & 84.4 & 55.4 \\
\hline & $+\mathrm{OM}$ & 94.8 & 96.0 & 92.3 & 85.3 & 68.2 \\
\hline & LSD & NS & NS & NS & NS & $* *$ \\
\hline
\end{tabular}

$-\mathrm{OM}=$ outside the plot, without remaining organic matter; $+\mathrm{OM}=$ in the plot, bellow of the remaining organic matter; $\mathrm{NS}=$ not significant; * significant at $\mathrm{P}<0.05$, ** significant at $\mathrm{P}<0.01$;

$* * *$ significant at $\mathrm{P}<0.001$.

Contrasting species in terms of organic matter quality and litter decomposition were found to correspond in terms of litter decomposition. A. mangium and C racemosa, that presented high and intermediate $\mathrm{C}$-to- $\mathrm{N}$ ratios, respectively, and intermediate and low lignin and phenol content, showed a significantly greater decrease in dry matter (DM) after 96 days. 
Decomposition in exposed litter bags might have been enhanced due to larger variations in moisture content, leaching, UV-radiation, and temperature. Dry weight of buried litterbags might have been also affected by contamination from above (leaching), but this was not clear for all treatments and time in this experiment.

\subsubsection{Nitrogen release}

Nitrogen release from leguminous plant residues followed different patterns than weight loss (Figure 28). All treatments showed a distinct net $\mathrm{N}$ accumulation in the litter bags throughout the study time. Only $A$. angustissima showed an initial $\mathrm{N}$ release, following which the $\mathrm{N}$ concentration increased in the remaining material (Figure 28). Nitrogen accumulation was significantly affected by species $(\mathrm{P}<0.01)$, decomposition time $(\mathrm{P}<0.01)$ and quality of material $(\mathrm{P}<0.01)$.

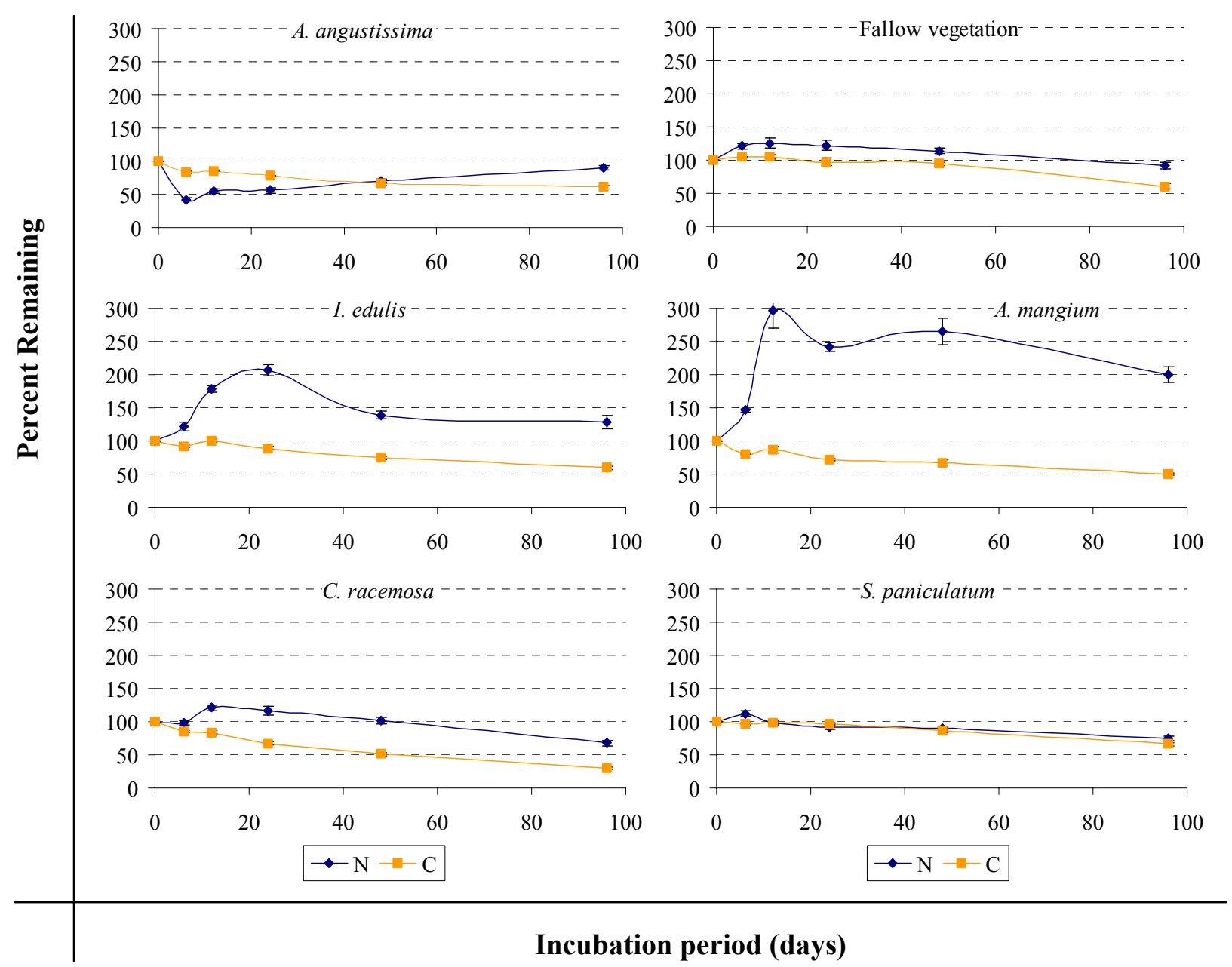

Figure 28. Remaining $\mathrm{N}$ and $\mathrm{C}(\%)$ in litter bags material during decomposition for five leguminous species and a fallow vegetation (control), in Igarapé-Açú, Brazil (Bars represent standard error of the mean). 
A. mangium, with the highest aboveground biomass production (Brienza 1999) and the highest C-to-N ratios, and I. edulis, with the highest lignin concentration and intermediate phenol concentration, accumulated the most net $\mathrm{N}$ during the first 3 weeks. At the end of the experiment only $A$. angustissima, with high $\mathrm{C}$-to-N ratio, $\mathrm{P}$ and phenol concentration, showed an increase in net $\mathrm{N}$ accumulation (Figure 28).

Exposed $-O M$ and buried $+O M$ litter bags showed significant differences $(\mathrm{P}<0.05)$ in $\mathrm{N}$ release and accumulation during the experiment (Table 36). The significant loss was greater in exposed -OM in the majority of sampled time. But, at the end of the experiment, the control, I. edulis, and S. paniculatum did not show differences between the two places (inside or outside of the plot). In the same way as the buried $+O M$, the exposed $-O M$ also showed increases in $\mathrm{N}$ concentration.

Weight loss was a poor predictor for $\mathrm{N}$ release. For A. mangium, I. edulis and the control, net N release was not observed. C. racemosa and S. paniculatum released N, but these species showed an initial accumulation or maintained the initial $\mathrm{N}$ concentration until halfway through the experimental period. A. angustissima showed an initial $\mathrm{N}$ release but after that this treatment increased the amount of $\mathrm{N}$.

A. angustissima, with better initial $\mathrm{P}$ and $\mathrm{N}$ concentrations, had a contrasting net $\mathrm{N}$ release and accumulation in comparison with the other treatments. A. mangium, which presented greater C-to-N ratios and intermediate lignin and phenol contents. I. edulis, with intermediate and high initial $\mathrm{P}$ and $\mathrm{N}$ concentration and high lignin and intermediate phenol concentrations, respectively, showed a more pronounced increase in the amount of $\mathrm{N}$ initially.

Increases in nitrogen during decomposition time have been reported by Melillo et al. (1982), Hunt et al. (1988), Blair et al. (1990), Constantinides and Fownes (1994a), and others. The explanations for the absolute increases include additions of $\mathrm{N}$ with one or more of the subsequent processes: fixation, absorption of atmospheric ammonia, throughfall, dust, faeces, green litter, fungal translocation and/or immobilization. Litterbag experiments cannot measure this number of interferences, and due to the high number of no-controlled factors the litterbag experiment maybe is not the better method for the analyze of mulch decomposition and nitrogen release. 
Table 36. $\mathrm{N}$ remaining (\%), during the decomposition of 5 leguminous species and a control (fallow vegetation) as affected by exposure on surface soil and burial under a thick mat of mulch $(+\mathrm{OM})$.

\begin{tabular}{|c|c|c|c|c|c|c|}
\hline \multirow{2}{*}{ Species } & \multirow{2}{*}{ Status } & \multicolumn{5}{|c|}{ Time (days) } \\
\hline & & 6 & 12 & 24 & 48 & 96 \\
\hline \multirow[t]{3}{*}{ A. angustissima } & $-\mathrm{OM}$ & 101.6 & 42.8 & 73.9 & 52.7 & 44.0 \\
\hline & $+\mathrm{OM}$ & 41.7 & 54.5 & 55.9 & 70.4 & 89.9 \\
\hline & LSD & $* * *$ & $* *$ & $* * *$ & $* * *$ & $* * *$ \\
\hline \multirow[t]{3}{*}{ Fallow (control) } & $-\mathrm{OM}$ & 133.6 & 120.4 & 75.8 & 71.4 & 75.4 \\
\hline & $+\mathrm{OM}$ & 121.5 & 125.7 & 122.4 & 113.8 & 91.8 \\
\hline & LSD & NS & NS & $* * *$ & $* *$ & NS \\
\hline \multirow[t]{3}{*}{ I. edulis } & $-\mathrm{OM}$ & 133.0 & 121.0 & 137.4 & 130.1 & 107.3 \\
\hline & $+\mathrm{OM}$ & 121.1 & 179.0 & 206.4 & 138.6 & 128.0 \\
\hline & LSD & NS & $* * *$ & $* * *$ & NS & NS \\
\hline \multirow[t]{3}{*}{ A. mangium } & $-\mathrm{OM}$ & 168.1 & 137.0 & 204.5 & 155.4 & 93.7 \\
\hline & $+\mathrm{OM}$ & 146.0 & 296.5 & 242.1 & 264.6 & 199.3 \\
\hline & LSD & NS & $* * *$ & NS & $* * *$ & $* * *$ \\
\hline \multirow[t]{3}{*}{ C. racemosa } & $-\mathrm{OM}$ & 89.0 & 96.5 & 75.6 & 60.6 & 14.8 \\
\hline & $+\mathrm{OM}$ & 98.2 & 120.9 & 116.3 & 101.3 & 67.5 \\
\hline & LSD & NS & $* *$ & $* * *$ & $* * *$ & $* * *$ \\
\hline \multirow[t]{3}{*}{ S. paniculatum } & $-\mathrm{OM}$ & 101.1 & 77.9 & 84.8 & 85.0 & 69.2 \\
\hline & $+\mathrm{OM}$ & 112.5 & 98.1 & 91.8 & 89.9 & 74.4 \\
\hline & LSD & $*$ & $* * *$ & NS & NS & NS \\
\hline
\end{tabular}

$-\mathrm{OM}=$ outside the plot, without remaining organic matter; $+\mathrm{OM}=$ in the plot, bellow of the remaining organic matter; ${ }^{\mathrm{NS}}=$ not significant; * significant at $\mathrm{P}<0.05, * *$ significant at $\mathrm{P}<0.01$; *** significant at $\mathrm{P}<0.001$.

Nutrients such as $\mathrm{N}$, which are often limiting microbial growth, are immobilized where carbon supply is plentiful and nutrient concentrations are low, and mineralized as carbon content decreases and nutrient concentration increases (Stevenson and Cole 1999). Also, 
increases in concentration of $\mathrm{N}$ in dry litter material, principally woody material, should be expected after rainfall and, following that, infiltration of litter-leached solution.

This field experiment was initially projected for one year of sampling time. However, due the problems with the last weighing of the litterbags, all results were showed for 96 days. But for estimate the N-mineralization rate constant $(k)$ for one year of the experiment, the litterbags weight were obtained using the better exponential model for each treatment, which were showed in the Figure 27.

The $\mathrm{N}$-mineralization rate constant $(k)$ of prunings and the percentage of $\mathrm{N}$ release after 1 year was correlated with some chemical properties for the species and control (Table 37). There were, however, differences in the coefficient of determination for the linear regression between the $k$ values and the percent of $\mathrm{N}$ released after 1 year. The lignin-to-P ratio gave the highest coefficient of determination for $k$, but phenol-to-cellulose ratio and phenol showed the better coefficient of determination for percentage of $\mathrm{N}$ realized.

Table 37. Coefficients of determination $\left(r^{2}\right)$ for linear regressions between initial substrate quality variables from five legumes species and natural fallow vegetation (as control) and $\mathrm{N}$ mineralization rate constants after one year of field decomposition. The variables were selected by being more frequently cited in the revised literature.

\begin{tabular}{lcc}
\hline $\begin{array}{l}\text { Mulch initial quality } \\
\text { variable }\end{array}$ & $\begin{array}{c}\text { N Mineralization rate } \\
\text { constant, } k\left(\text { days }^{-1}\right)\end{array}$ & $\begin{array}{c}\text { Percentage of N } \\
\text { observed after 1 year }\end{array}$ \\
\hline$k$ & $0.704^{*}$ & $0.806^{* *}$ \\
Phenol & $0.222^{\text {ns }}$ & $0.839^{* *}$ \\
Lignin + Phenol & $0.541^{\text {ns }}$ & $0.752^{*}$ \\
C-to-N ratio & $0.701^{*}$ & $0.731^{*}$ \\
C & $0.632^{\text {ns }}$ & $0.764^{*}$ \\
Phenol + Lignin-to-N ratio & $0.596^{\text {ns }}$ & $0.792^{*}$ \\
Phenol-P ratio & $0.850^{* *}$ & $0.757^{*}$ \\
Lignin-to-P ratio & $0.704^{*}$ & $0.730^{*}$ \\
Phenol + lignin-to-P ratio & $0.671^{*}$ & $0.793^{*}$ \\
Phenol-to-Cellulose ratio & $0.051^{* *}$
\end{tabular}

\footnotetext{
${ }^{\mathrm{ns}}$ is not significant; ${ }^{*}$ is significant at $\mathrm{P}<0.05$; and ${ }^{* * *}$ is significant at $\mathrm{P}<0.01$
} 
The initial phenol-to-cellulose ratios $(\mathrm{P}<0.01)$ and initial phenol concentration $(\mathrm{P}=0.01)$ were the better parameters to predict $\mathrm{N}$ release (Figure 29). The litter quality of an organic material depends on the proportions of soluble carbon, cellulose and lignin (Mafongoya et al. 1998). Soluble carbon, which includes metabolic and storage carbon, is of high quality and is primarily responsible for promoting microbial growth and activity (Smith 1994). Large amounts of soluble carbon but little soluble $\mathrm{N}$ and $\mathrm{P}$ in the decomposing plant materials induce net immobilization (Melillo et al. 1982).
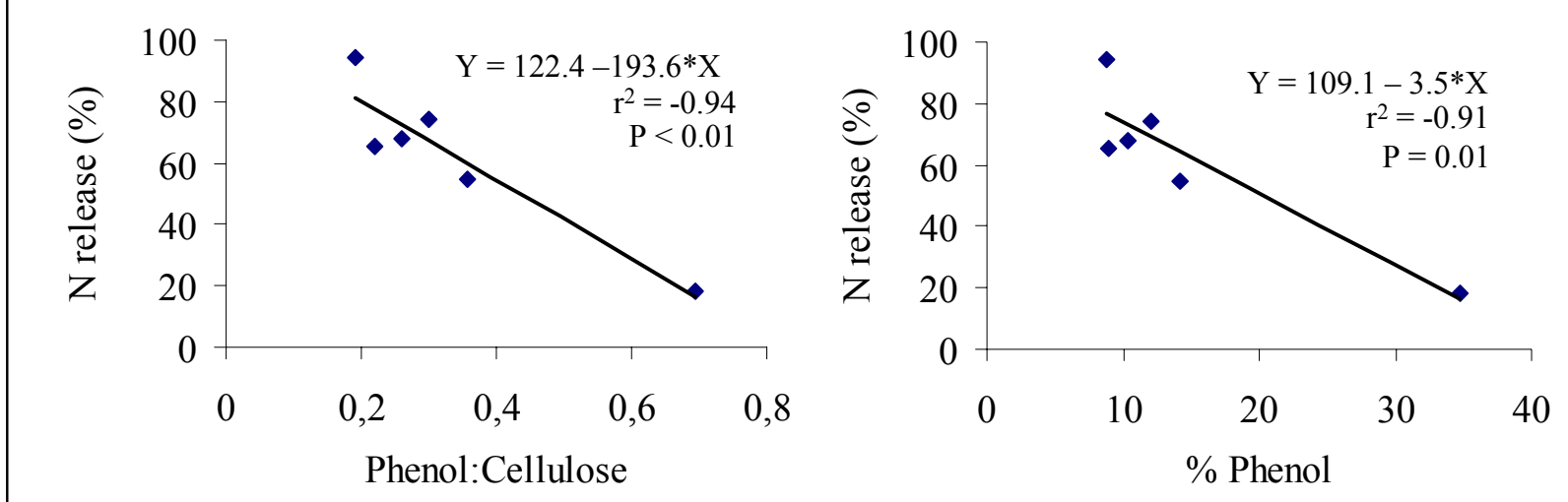

Figure 29. Linear regression coefficients indicating predicted N-release from decomposition of five different leguminous trees and control (Fallow vegetation).

The increases in $\mathrm{N}$ concentration during the litter bag decomposition can be explained by the following. High polyphenol and lignin concentrations could be major factors in $\mathrm{N}$ accumulation during decomposition. Lignin plays a barrier role that prevents the activity of cellulolytic microorganisms and reduces the litter decomposition rate (Palm and Rowland 1997). Fast leaching of a major fraction of soluble polyphenol in from the mulch surface probably yielded stable polymers that bind $\mathrm{N}$ in different forms, and thus immobilize $\mathrm{N}$ (Martin and Haider 1980).

The interaction of polyphenolics with $\mathrm{N}$ and the fate of the $\mathrm{N}$ depend on the type of polyphenolics present in the plant material. Some polyphenolics form complex structures by H-bonding with basic N-containing compounds, others form stable cross linkages with amino groups making the material resistant to decomposition (Palm and Sanchez 1991). The stable polymers formed between phenolics and N-containing compounds have characteristics similar to, and are considered precursors to, the fulvic and humic acids found in soil organic matter (Martin and Haider 1980, Stevenson and Cole 1999). 
Another interaction between phenolics and $\mathrm{N}$ is referred to as nitrosation, a chemical reaction of $\mathrm{NO}_{2}^{-}$with phenolics, forming stable organic $\mathrm{N}$ compounds (Nelson and Bremner 1969). Although $\mathrm{NO}_{2}{ }^{-}$is generally low in soils, $\mathrm{NO}_{2}{ }^{-}$is formed during the process of nitrification, and nitrosation could account for the apparent immobilization of inorganic N (Azhar et al. 1986). In this direction, the initial rapid immobilization could be explained by nitrosation, with soluble polyphenolics that leached from the leaves into mulch system and bind to $\mathrm{NO}_{2}{ }^{-}$, formed during nitrification and immobilize $\mathrm{N}$.

The relationship between N-mineralization and cellulose presumably reflects the rate of Nimmobilization by the saprophytic microflora as it utilizes the compound as an energy source. In most studies of quality factors affecting mineralization from plant material, the cellulose fraction has been divided in hemicelluloses and $\alpha$-cellulose components, which have each been used separately to determine their suitability as N-mineralization predictors (Bending et al. 1998).

Results of this study confirm the complexity of decomposition processes where the interaction of both, resource quality and microclimate influence the conditions and activity of decomposer communities and those, in turn, mediate processes of decomposition and nutrient release (Hunt et al. 1988, Neely et al. 1991, Thönnissen et al. 2000). Organic matter used as mulch should not be compared with incorporated organic matter because of the different functions involved. This study also demonstrated that polyphenol content may play an important role in influencing mineralization patterns for leguminous plant material. Differences in the type and amount of soluble polyphenol present in the mulch material could explain the initial net release or immobilization of $\mathrm{N}$. The significant correlation between $\mathrm{N}$ release and phenol concentration demonstrate the primary importance of this element in determining the mineralization patterns obtained.

The A. mangium and I. edulis treatments proved to be the better contrasting species in comparison to C. racemosa, S. paniculatum, and fallow control in terms of $\mathrm{N}$ dynamics. These two groups contrasted again with $A$. angustissima. Lignin, phenol, $\mathrm{P}$, lignin + phenolto-nitrogen ratios, and phenol-to-phosphorus ratios showed better correlation with $\mathrm{N}$ dynamics for the majority of the species studied. But the better predictors of $\mathrm{N}$ release were phenol-to-cellulose ratios and phenol (\%).

Based on these field results, the slash-and-mulch systems with thick mats of mulch need to be improved for the synchronization of nutrient release from organic material and nutrient uptake by the crop systems. Use of contrasting plant material in terms of litter quality, carbon input 
reduction with the selective removal of wood, and soil incorporation of fallow residues need to be further tested.

\section{GENERAL DISCUSSION}

Decline in soil productivity and environmental quality and progressive deterioration of natural resources in the tropics have led to a search for new methods to sustain crop production via more efficient nutrient cycling. In agricultural ecosystems in the tropics with limited access to fertilizers, plant residues are often used to meet the $\mathrm{N}$ requirements of annual food crops (Constantinides and Fownes 1994a). The added organic materials are potentially important sources of N, C and P in crop production, especially for resources-poor farmers on tropical agricultural land. In order to successfully manage organic materials, the release and uptake of $\mathrm{N}$ by crops must be identified (Hood 2002). But the predictions of net $\mathrm{N}$-mineralization are in many cases unreliable because net $\mathrm{N}$-mineralization is affected by $\mathrm{N}$ immobilization and remineralization and losses (Stark and Schimel 2001).

The slash and burn system destroys the above-ground biomass of the fallow vegetation including the litter by burning, which causes loss of nutrients through volatilization and leaching of free nutrients in ash by rainfall. The losses of nitrogen by volatilization and leaching can reach 95-98\% (Mackensen et al. 1996). Cerri et al. (1991) observed a reduction of $25 \%$ in soil carbon content two years after a plot was cleared, burned and a satisfactorily managed pasture established. However, Kato (1998) showed no reduction in carbon content in the mineral soil in the slash and burn system, and attributed this to the biomass accumulated by the rice crop.

The concept of pools of organic matter that differ in their susceptibilities to microbial decomposition and their longevity in soil has provided a basis for understanding the dynamic nature of soil organic matter and how nutrient availability is influenced by management practices and changes in the soil environment (Stevenson and Cole 1999). Our study showed that the patterns of the added organic carbon need to be taken into consideration. This was supported by the strong correlation between nitrogen dynamics in the contrasting legumesamended soil and soil microbial biomass and organic carbon, found in this study.

Dissolved organic substances contribute to plant nutrition with nitrogen. Due to their water solubility there is a considerable risk that leaching of these substances will result in enhanced soil degradation. The dynamics of dissolved organic substances is influenced by the quantity and the quality of soil organic mater, the sorption characteristics of the soils and the microbial activity. All these parameters are modified by land use. 
When immobilization and mobilization processes of $\mathrm{N}$ in soil are managed, it is important to quantify the real amount of $\mathrm{N}$ stored in the soil microbial biomass (Joergensen and Mueller 1996). Transient immobilization of soil $\mathrm{N}$ in the microbial biomass may contribute to improved conservation of soil N sources (Jensen 1997).

\subsection{Soil incorporated organic matter decomposition and nitrogen mineralization and immobilization.}

The higher initial concentrations of soil inorganic nitrogen in the high-N treatments would unlikely increase nitrogen immobilization significantly in the absence of added organic matter because nitrogen immobilization is generally limited by available carbon (Recous et al. 1988, Bremer and Kuikman 1997). Thus, fertilizer added as urea-N did not lead to differences in total mineral-N and microbial biomass- $\mathrm{N}$ in soil without added organic material during the incubation period (Table 38). Urea increased total microbial biomass-N and decreased total mineral-N, which suggests that fertilizer increased microbial biomass and thus nitrogen consumption by soil microorganism.

On the other hand, the increase in soil organic carbon and nitrogen due to added legume leaf + wood material resulted in a decrease in $\mathrm{N}$-min and microbial biomass ${ }^{17}$ in comparison with control treatment (Table 38). Assuming that the fumigation-extraction method did not measure the fungal $\mathrm{N}$-absorption, resulting in a underestimation of $\mathrm{N}$-immobilization, and that the mineralization and losses of indigenous soil nitrogen were similar in the control and residue-treated soil, the real nitrogen immobilization and consumption was 63.2 and $37.7 \mu \mathrm{g}$ $\mathrm{N} \mathrm{g}^{-1}$ soil for S. paniculatum and I. edulis treatment, respectively. This means that the nitrogen in microbial biomass (microbial nitrogen immobilization and consumption) was approximately 9.3 and 1.0 times more than the mineral- $\mathrm{N}$ found in the same treatments, respectively.

\footnotetext{
${ }^{17}$ Using fumigation-extraction and steam distillation procedure.
} 
Table 38. Nitrogen-mineral ${ }^{\Phi}\left(\mu \mathrm{g} \mathrm{N} \mathrm{g}^{-1}\right.$ soil) and N-microbial biomass ${ }^{\Psi}\left(\mu \mathrm{g} \mathrm{N} \mathrm{g}^{-1}\right.$ soil) for incorporated leaf + wood material in comparison with incorporated leaf material + Urea as fertilizer, during the incubation time and total. The numbers represent mean (Standard error).

\begin{tabular}{|c|c|c|c|c|}
\hline \multirow{2}{*}{$\begin{array}{l}\text { S. paniculatum } \\
\text { Incubation period } \\
\text { (days) }\end{array}$} & \multicolumn{2}{|c|}{$\begin{array}{c}\text { N-mineral } \\
\left(\mu \mathrm{g} \mathrm{N} \mathrm{g}^{-1} \text { soil }\right)\end{array}$} & \multicolumn{2}{|c|}{$\begin{array}{l}\text { N-microbial biomass } \\
\qquad\left(\mu \mathrm{g} \mathrm{N} \mathrm{g}^{-1} \text { soil }\right)\end{array}$} \\
\hline & $\begin{array}{c}\text { leaf }+ \text { wood } \\
\text { material }\end{array}$ & $\begin{array}{l}\text { leaf material } \\
+ \text { fertilizer }\end{array}$ & $\begin{array}{c}\text { leaf }+ \text { wood } \\
\text { material }\end{array}$ & $\begin{array}{l}\text { leaf material } \\
+ \text { fertilizer }\end{array}$ \\
\hline 0 & 2.7(0.04) & $\mathbf{1 9 . 5}(1.81)$ & $\mathbf{0 . 6}(0.50)$ & 4.8(1.33) \\
\hline 4 & $\mathbf{0 . 5}(0.14)$ & $\mathbf{1 5 . 5}(1.42)$ & $\mathbf{0 . 8}(0.06)$ & 5.2(1.88) \\
\hline 16 & $\mathbf{0 . 7}(0.11)$ & 13.4(0.28) & $\mathbf{0 . 3}(0.09)$ & 6.3(3.38) \\
\hline 64 & $\mathbf{1 . 1}(0.12)$ & 31.5(1.46) & $\mathbf{0 . 1}(0.07)$ & $\mathbf{5 . 5}(0.71)$ \\
\hline Total & 5.0 & 79.9 & 1.8 & 21.8 \\
\hline I. edulis & \multicolumn{2}{|c|}{$\begin{array}{l}\text { Total N-mineral } \\
\left.\text { ( } \mu \mathrm{g} \mathrm{N} \mathrm{g}^{-1} \text { soil }\right)\end{array}$} & \multicolumn{2}{|c|}{$\begin{array}{c}\text { Total N-microbial biomass } \\
\qquad\left(\mu \mathrm{g} \mathrm{N} \mathrm{g}^{-1} \text { soil }\right)\end{array}$} \\
\hline $\begin{array}{l}\text { Incubation period } \\
\text { (days) }\end{array}$ & $\begin{array}{c}\text { leaf }+ \text { wood } \\
\text { material }\end{array}$ & $\begin{array}{l}\text { leaf material } \\
+ \text { fertilizer }\end{array}$ & $\begin{array}{c}\text { leaf }+ \text { wood } \\
\text { material }\end{array}$ & $\begin{array}{l}\text { leaf material } \\
+ \text { fertilizer }\end{array}$ \\
\hline 0 & $\mathbf{8 . 3}(0.44)$ & $\mathbf{5 4 . 5}(0.84)$ & $\mathbf{3 . 6}(0.24)$ & 19.3(3.48) \\
\hline 4 & 9.7(0.08) & $\mathbf{5 1 . 7}(0.80)$ & $\mathbf{1 . 1}(0.14)$ & 18.2(1.82) \\
\hline 16 & $7.1(0.11)$ & $\mathbf{5 7 . 7}(1.23)$ & $1.2(0.10)$ & 19.4(1.62) \\
\hline 64 & 2.7(0.09) & $\mathbf{5 2 . 0}(1.66)$ & $\mathbf{2 . 6}(0.17)$ & 14.2(2.61) \\
\hline Total & 27.8 & 215.9 & 8.5 & 71.1 \\
\hline Control & \multicolumn{2}{|c|}{$\begin{array}{l}\text { Total N-mineral } \\
\left(\mu \mathrm{g} \mathrm{N} \mathrm{g}^{-1} \text { soil }\right)\end{array}$} & \multicolumn{2}{|c|}{$\begin{array}{c}\text { Total N-microbial biomass } \\
\qquad\left(\mu \mathrm{g} \mathrm{N} \mathrm{g}^{-1} \text { soil }\right)\end{array}$} \\
\hline $\begin{array}{l}\text { Incubation period } \\
\text { (days) }\end{array}$ & & fertilizer & & fertilizer \\
\hline 0 & 13.1(0.16) & $\mathbf{1 7 . 8}(2.04)$ & $\mathbf{1 . 3}(0.25)$ & $4.8(0.36)$ \\
\hline 4 & $14.8(0.26)$ & $12.9(0.95)$ & $4.9(0.25)$ & $\mathbf{1 . 8}(0.41)$ \\
\hline 16 & $16.0(0.09)$ & 13.3(0.10) & 2.2(0.08) & $\mathbf{0 . 7}(0.55)$ \\
\hline 64 & $\mathbf{2 0 . 4}(0.13)$ & 12.7(0.18) & $\mathbf{1 . 3}(0.01)$ & 4.6(1.37) \\
\hline Total & 64.3 & 56.7 & 9.7 & 11.9 \\
\hline
\end{tabular}

\footnotetext{
${ }^{\Phi}$ Nitrogen-mineral was examined with steam distillation procedure.

${ }^{\Psi} \mathrm{N}$-microbial biomass was measured with fumigation-extraction procedure.
} 
On the other hand, the increase in soil organic carbon and nitrogen due to added legume leaf + wood material resulted in a decrease in $\mathrm{N}$-min and microbial biomass ${ }^{18}$ in comparison with control treatment (Table 38). Assuming that the fumigation-extraction method did not measure the fungal $\mathrm{N}$-absorption, resulting in a underestimation of $\mathrm{N}$-immobilization, and that the mineralization and losses of indigenous soil nitrogen were similar in the control and residue-treated soil, the real nitrogen immobilization and consumption was 63.2 and $37.7 \mu \mathrm{g}$

$\mathrm{N} \mathrm{g}^{-1}$ soil for $S$. paniculatum and I. edulis treatment, respectively. This means that the nitrogen in microbial biomass (microbial nitrogen immobilization and consumption) was approximately 9.3 and 1.0 times more than the mineral-N found in the same treatments, respectively.

The withdrawal of the wood material and added nitrogen as fertilizer yielded a strong increase in N-mineralization in comparison with wood material only and control. This suggests that these soils in this Amazon region are very nitrogen and carbon limiting and the microbial competition is very intensive.

\subsection{Nitrogen mineralization, immobilization and rice absorption}

Microbial immobilization of labelled nitrogen was unaffected by rice plant growth, but was strongly affected by organic matter and nitrogen addition. Immobilization of nitrogen by organic matter decomposers was determined primarily by the amount and accessibility of available nitrogen. Differences in nitrogen immobilization by decomposers of the legume organic matter were greatest between $\mathrm{N}$ treatments, but were also affected by mixture of two contrasting legume materials

Rice growth and nitrogen accumulation closely reflected the differences in chemical composition and mineralization between the residues and their mixture. Approximately the same amount of nitrogen was added in all legume treatments, and yet the amount of nitrogen accumulated differed with the legume quality. The use of a mixture of two contrasting litter qualities improved the rice recovery of nitrogen derived from urea-fertilizer and the rice recovery of nitrogen derived from legume material.

\subsection{Field mulch decomposition and $\mathrm{N}$-mineralization and immobilization}

Soluble carbon, which includes metabolic and storage carbon, is of high quality and is primarily responsible for promoting microbial growth and activity (Smith 1994). Large

\footnotetext{
${ }^{18}$ Using fumigation-extraction and steam distillation procedure.
} 
amounts of soluble carbon but little soluble nitrogen and phosphorous in the decomposing plant materials induces net immobilization (Melillo et al. 1982).

Decomposition and N-mineralization in the field from various plant residues as mulch followed different patterns. Nitrogen release rates varied with species, time and litter bag placement. Lignin, phenol, phosphor, lignin + phenol-to-nitrogen ratios, and phenol-tophosphorous ratios showed reasonably good correlation with $\mathrm{N}$ dynamics for the majority of the studied species. But the better predictors of $\mathrm{N}$ release were phenol-to-cellulose ratio and phenol (\%).

The patterns of N-mineralization in mulch obtained in this study are complex and involve a variety of factors, which were strongly different from decomposition of soil-incorporated organic matter. This study suggests that cellulose, as a carbon source, and polyphenol content might control the short-term $\mathrm{N}$ release and availability from mulch.

In accordance with Palm and Sanchez (1991), the use of legume trees with low polyphenol content used as mulch can release nitrogen and provides nitrogen for crop growth. Legumes with high level of polyphenols that may react with organic nitrogen compounds do not provide adequate nitrogen for plant growth in the short term. However, they may contribute to the to build-up of organic nitrogen in the soil and provide a low but continual supply of nitrogen in the long term. From our results it appears that the mixing of two contrasting trees in terms of litter quality provides the best fallow management when the mulch system alternative is used. The slash-and-mulch systems with thick mats of mulch need to be improved for the synchronization of nutrient release from organic material and nutrient uptake by crop systems. Use of contrasting plant material in terms of litter quality, carbon reduction in the vegetation with the selective removal of wood, and soil incorporation of fallow residues need to be further tested.

Alternatively, selective biomass input into soil can be made during the fallow period in the mulch system. It can be done by systematic felling of trees with high C-to-N ratio, with the objective of improving soil organic carbon, compensating for the long-term losses experienced with the burning of biomass. In addition the use of enriched fallow techniques with contrasting legume material in terms of phenol, cellulose, nitrogen and phosphorus content, and the use of this biomass as mulch can result in a decrease in the need for fertilizer by poor farmers in Amazon region. 


\section{CONCLUSIONS}

This study showed that the quality and the quantity of organic carbon presented an important factor affecting soil nitrogen mineralization and immobilization. Changes in soil carbon substrates influenced the dynamics of soil inorganic nitrogen because of the importance of labile carbon in the microbial immobilization and consumption of nitrogen. Compton and Boone (2002) showed that the light fraction of soil organic matter incorporated more ${ }^{15} \mathrm{~N}$ than the heavy fraction per unit of carbon, which indicated that not simply the amount but the composition of organic matter controls its function as a site for $\mathrm{N}$ incorporation.

Soil microbial biomass immobilizes a higher amount of the residue $\mathrm{N}$ mulched or incorporated into the soil and this needs to be taken into consideration. On the other hand, soil microbial biomass immobilization is a labile repository of nitrogen, their turnover and remineralization may conserve this $\mathrm{N}$ in the system and release this $\mathrm{N}$ for later plant use.

Legume-enriched mulch material had different patterns of mulch decomposition and nutrient release. As was pointed out earlier by Constantinides and Fownes (1994a), Fox et al. (1990), the contents of $\mathrm{N}$, lignin and polyphenol are the principal chemical factors controlling degradability of plant material. The high correlation with the ratio of $\mathrm{N}+\mathrm{P}$-to-phenol and Nmineralization implies that the plant nutrients which limit microbial action govern decomposition and nutrient release. This is likely associated with the formation of stable polymers with many forms of $\mathrm{N}$ binding $\mathrm{N}$ released to the soil by the incorporated organic matter.

The use of fast-growing legumes for fallow enrichment, as for example A. mangium, does not necessarily translate directly in a $\mathrm{CO}_{2}$ sequestration, because the fast decomposition rate. Species, contrasting in lignin and polyphenol concentration with higher N-and P-content must be used for enrichment fallow. The I. edulis and S. paniculatum, two Amazon species, showed greater promise as enrichment candidates, because of their high organic $\mathrm{C}$ input in combination with low losses of OM.

Since immobilization of $\mathrm{N}$ is generally determined by the amount of decomposable carbon present in the soil rather than by the amount of inorganic $\mathrm{N}$, the addition of compost showing a wide $\mathrm{C}$-to- $\mathrm{N}$ ratio accelerates $\mathrm{N}$-immobilization through increased microbial activity. Contrasting leguminous species had different patterns of net $\mathrm{N}$-mineralization and immobilization in comparison with the single species. The use of two contrasting leguminous species increased the nitrogen absorption by rice through the increase of mineral $\mathrm{N}$ and decrease of microbial $\mathrm{N}$-immobilization. 
Managing soil biological processes is a key aspect of sustainable development. The researchers must better understand soil organisms, their functions and their interactions with the chemical and physical environment. Many aspects of soil biology and ecology are worthy of research in view of their fundamental scientific interest and their role in ecosystem functioning.

The increase of agriculture in the Amazon region cannot be done by the increase of deforestation and the scope of an increase in fertilizer use is limited. Thus, the intensification and improvement of currently managed land would have to be attempted. Fallow-mulch system is a considerable challenge and calls for more research. The agricultural policy in the Amazon region could promote organic agriculture with incentives to production and facilitating the commercialization of Amazon organic agricultural products. 


\section{SUMMARY}

In Amazon human activities such as slashing and burning converted large areas of primary forest to intermittently used agricultural land. Thus, the fallow vegetation plays an important role to maintain or restore soil productivity. However, the intensification of land use has drastically reduced the fallow period. Therefore, the soil quality has to be restored in shorter time. The efficiency with which $\mathrm{N}$ in plant residues is used depends on the rate at which they are mineralized and thus on the time when they are made available relative to crop requirements. The present dissertation is proposed to find contrasting legume litter quality in terms of $\mathrm{N}$ mineralization and, by mixing this organic material, it will be possible to alter the pattern of $\mathrm{N}$-release and the efficiency of utilization of $\mathrm{N}$ from the residue by a soil microbial biomass and crop system. Various species of leguminous trees were evaluated.

To test the role of manipulation of litter quality to regulate nutrient release, a laboratory incubation study was conducted of the decomposition rates of different fractions of leaf + wood material from some selected field leguminous trees. The objective was to determine Nmineralization and-immobilization in mixtures of material from different species with contrasting pruning quality. After incorporation into soil we studied the resulting pattern of Nrelease and the efficiency of utilization of $\mathrm{N}$ by soil microorganisms and the crop.

The laboratory incubation experiment with different species showed that net soil nitrogen mineralization without added organic matter was five times greater than in any of the other treatments. In the absence of fresh organic matter and no leaching the consumption of $\mathrm{NO}_{3}{ }^{-}$ by microorganisms was low leading to net release of nitrate. Net N-mineralized in leguminous-amended soil was significantly different for the two species used and their mixture with time and for interaction species and time. The final inorganic $\mathrm{N}$ content in legume-amended soil ranged from 2.0 to $6.1 \mathrm{mg} \mathrm{N} \mathrm{kg}^{-1}$ soil compared with $1.6 \mathrm{mg} \mathrm{N} \mathrm{kg}^{-1}$ soil in the fallow-amended soil and $20.7 \mathrm{mg} \mathrm{N} \mathrm{kg}^{-1}$ soil in the control soil. Thus, at the end of incubation period, mineral nitrogen decreased in the following order: Soil as control $>S$. paniculatum $>$ I. edulis $>$ A. mangium $>$ A. angustissima $>$ natural fallow. Both leguminous residues and the mixture of the two contrasting species caused a net immobilization of soil inorganic $\mathrm{N}$ during the complete incubation period. The mixture of two contrasting organic matter qualities showed significantly different patterns of net $\mathrm{N}$-mineralization and net $\mathrm{N}$ immobilization in comparison with the same species separately. In soil, N-mineralization increased with increases $\mathrm{CO}_{2}$ production and organic $\mathrm{C}$ concentration. In contrast, $\mathrm{N}$ immobilizations by soil microorganism increased with an increased in $\mathrm{CO}_{2}$ and organic $\mathrm{C}$ 
production, and increased with a decreased in N-concentrations. This suggested that $\mathrm{N}-$ dynamics in the legume-amended treatments were highly correlated with soil microbial biomass and organic $\mathrm{C}$ dynamics. Initial Phenol-to-N and phenol + lignin-to-N ratios were negatively bettered correlated with total net $\mathrm{N}$-mineralization for leguminous species and mixtures. However, initial organic $\mathrm{N}$ was significantly and positively correlated with total net $\mathrm{N}$-mineralization. This experiment showed that a mixture of contrasting leguminous species had different patterns of net N-mineralization and immobilization than of the single species. The I. edulis treatment presented the higher N-mineralization whereas $S$. paniculatum treatment showed the higher interaction with other leguminous species in terms of $\mathrm{N}$ immobilization and mineralization. Both were selected for subsequent studies on the comparison of contrasting species in relation to gross $\mathrm{N}$-mineralization and -immobilization. The ${ }^{15} \mathrm{~N}$ greenhouse, which used rice as an indicator plant, and ${ }^{15} \mathrm{~N}$ labour experiments were divided in two parts: first, ${ }^{15} \mathrm{~N}$-urea fertilizer $\left(3.92 \mathrm{mg} \mathrm{N}_{\text {pot }}{ }^{-1}\right.$ with 5.34 atom $\left.\%{ }^{15} \mathrm{~N}\right)$ and leguminous leaf material (S. paniculatum, I. edulis and mixture of the two species) with $\mathrm{N}$ at natural abundance were combined to assess microbial immobilization and soil fixation. The second part used $\mathrm{N}$-urea fertilizer (3.92 $\mathrm{N} \mathrm{mg} \mathrm{pot}^{-1}$ with $\mathrm{N}$ at natural abundance) and ${ }^{15} \mathrm{~N}$ labeled leguminous organic material with 0.392 atom $\%{ }^{15} \mathrm{~N}$ in the S. paniculatum treatment, and 0.390 atom $\%{ }^{15} \mathrm{~N}$ in the I. edulis treatment, to assess the amount of mineral-N coming from organic matter decomposition. This also allowed an assessment of the extent of competition between microorganisms, soil fixation, and rice absorption. Microbial immobilization of labelled nitrogen was unaffected by rice plant growth, but was strongly affected by organic matter and nitrogen addition. Immobilization of nitrogen by organic matter decomposers was determined primarily by the amount and accessibility of available nitrogen. Differences in nitrogen immobilization by legume organic matter decomposers were greatest between $\mathrm{N}$ treatments, but were also affected by the mixture of two contrasting legume materials. In the greenhouse experiment using rice as an indicator plant, the treatment with mixture between two species had an intermediate cumulative soil ${ }^{15} \mathrm{~N}$ microbialimmobilization, higher cumulative rice biomass and total $\mathrm{N}$, and higher recovery of ${ }^{15} \mathrm{~N}$ from urea fertilizer. This indicates that interaction of two contrasting leguminous species increase the nitrogen absorption by rice thought the increases of mineral $\mathrm{N}$ and a decrease of gross microbial N-immobilization.

The field experiment with litterbags ran during one year, after a slash-and-mulch experiment. Contrasting species in terms of litter quality was used. The species were Acacia angustissima, A. mangium, Clitoria racemosa, Sclerolobium paniculatum, Inga edulis, and a mixture of 
species found in natural fallow vegetation. This field experiment showed that for the majority of the treatments an initial net N-release was not observed. Three of the treatments did not show any net $\mathrm{N}$-release during the experimental period. The A. angustissima treatment, which showed higher initial $\mathrm{P}$ and lower C-to-N ratio, had a faster net initial N-release with subsequent accumulation. The $A$. mangium treatment, with a greater $\mathrm{C}-\mathrm{to}-\mathrm{N}$ ratio and intermediate lignin and phenol content showed the greater increase in the amount of $\mathrm{N}$ concentration early in the rainy season. The same increase of $\mathrm{N}$-concentration was observed for I. edulis treatment, with intermediate initial $\mathrm{P}$ and high $\mathrm{N}$-concentration and high lignin and intermediate phenol concentration. These results suggested that slash-and-mulch systems with thick mats of mulch are too slow in releasing $\mathrm{N}$ and need to be improved for the synchronization of release with the demands by the crop.

This study showed that the quality and the quantity of organic material presented an important factor affecting soil nitrogen mineralization and immobilization. Changes in soil carbon substrates influenced the dynamics of soil inorganic nitrogen because of the importance of labile carbon in the microbial immobilization and consumption of nitrogen. Contrasting leguminous species had different patterns of net $\mathrm{N}$-mineralization and -immobilization in comparison with the single species. The use of two contrasting leguminous species increased the nitrogen absorption by rice through the increase of mineral-N in soil and a decrease of gross microbial $\mathrm{N}$-immobilization. The study demonstrates that the plant and microbial system compete for $\mathrm{N}$ in the soil, and the data showed a mutual $\mathrm{N}$ limitation and the use of the same N-resource. 


\section{ZUSAMMENFASSUNG}

In der Amazonienregion wurden durch Eingriffe des Menschen wie Zerschneiden und Verbrennen große Bereiche des Primärwaldes zu vorübergehend benutztem Ackerland umgewandelt. Folglich spielt die Brachevegetation eine wichtige Rolle, um die Bodenproduktivität beizubehalten oder wieder herzustellen. Jedoch hat die Intensivierung der Flächennutzung drastisch die Bracheperiode verringert. Diese Arbeit verfolgt im allgemeinen das Ziel, kontrastierende Müllzersetzung herauszufinden und den Einfluss der legumenosenartigen Bäume auf die Dynamik des Bodens N zu verfolgen, indem das Verbrennen durch die in dem Amazonas angereichert, mit Laub bedeckten „slash-and-mulch” Systeme ersetzt wird.

Die Leistungsfähigkeit, mit der N in den Pflanzenüberresten verwendet wird, hängt zum einen von der Mineralisierungsrate und zum anderen von der Zeit ab, wenn sie im Verhältnis zu den Getreideanforderungen zur Verfügung gestellt werden. Die vorliegende Studie unternimmt die Überprüfung, ob die kontrastierende „litter quality“ von Legumenosen in Bezug auf die $\mathrm{N}-$ Mineralisierung zu finden ist. Indem man dieses organische Material von unterschiedlichen Qualitäten mischt, soll verifiziert werden, ob es möglich ist, das Muster der N-Freigabe und der Leistungsfähigkeit der Anwendung von N vom Überrest durch eine Bodenmikrobenlebmasse und eine Zwischenfrucht zu ändern.

Um die Hypothese zur Handhabung der , litter quality “ auf die Nährfreigabe zu prüfen, wurden zwei Laborausbrütungsstudien, ein Gewächshausexperiment und ein Feldexperiment von der Aufspaltungsrate des unterschiedlichen Bruches des belaubten + hölzernen Materials von den gleichen ausgewählten legumenosenartigen Bäumen des Feldes vorgenommen. Die Zielsetzung ist, N-Mineralisierung und - Immobilisierung in den Mischungen von Sorten mit der kontrastierenden ,litter quality“, die im Boden enthalten ist, festzustellen und diese in Bezug auf deren resultierende Muster der N-Freigabe und der Leistungsfähigkeit der Anwendung von $\mathrm{N}$ durch Bodenmikroorganismen und Ernte zu untersuchen.

Die Laboruntersuchungen haben ergeben, dass die Nettobodenstickstoffmineralisierung ohne addierte organische Substanz fünfmal größer war, als in irgendeiner der anderen Behandlungen. In Ermangelung der frischen organischen Substanz und des nicht vorhandenen Auslaugens war der dazugehörige Verbrauch von $\mathrm{NO}_{3}{ }^{-}$durch Bodenmikroorganismen niedriger und führte dazu, das freigesetzte Nitrat aufzufangen. Das Netto-N, das in legumenosen-geändertem Boden mineralisiert wurde, war in Bezug auf die zwei Sorten erheblich unterschiedlich, die einerseits in der Mischung mit Zeit und andererseits in 
Wechselwirkung Sorte und Zeit verwendet wurden. Der wachsende anorganische Stickstoffgehalt in legumenosen-geändertem Boden reichte von 2,0 bis $6,1 \mathrm{mg} \mathrm{N} \mathrm{kg}^{-1}$ Boden, der mit 1,6 mg N kg${ }^{-1}$ Boden durch natürliche Brache-geänderten Boden und in 20,7 mg N kg${ }^{1}$ Boden im Kontrollprobe verglichen wurde. Die Abnahme des mineralisierten Nettostickstoffes steht in folgender Reihenfolge: Kontrolle $>S$. paniculatum $>$ I. edulis $>$ A. mangium $>$ A. angustissima $>$ natürliche Brache. Beide hülsenartigen Überreste und Mischungen von zwei kontrastierenden Sorten verursachten eine Nettoimmobilisierung des vom Bodenabgeleiteten anorganischen N während der kompletten Ausbrütungsperiode. Die Mischungen von zwei Qualitäten kontrastierender organischer Substanzen (Hülsenfruchtsorte) zeigten auffallend unterschiedliche Muster der Netto-Mineralisierung und -Immobilisierung im Vergleich mit den gleichen separaten Sorten.

Im Boden nimmt die N-Mineralisierung mit Zunahme der $\mathrm{CO}_{2}$-Produktion und des organischen $C$ zu. Im Gegensatz dazu steigen die N-Immobilisierungen durch Bodenmikroorganismen mit einem Zuwachs der $\mathrm{CO}_{2}$-Produktion und organischen C. Ferner nimmt die N-Immobilisierung mit einer Abnahme der N-Konzentrationen zu. Diese Beobachtung legt die Vermutung nahe, dass sich N-Dynamik in diesen hülsenartig-geänderten Behandlungen stark mit Bodenmikrobenlebendmasse und organischer C Dynamik

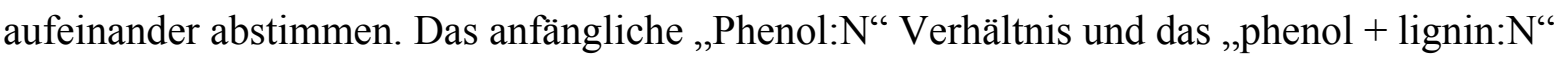
Verhältnis war negativ auf die gesamte Netto N-Mineralisierung für hülsenartige Sorten und Mischungen bezogen. Jedoch war das anfängliche organische Stickstoffe bedeutend und positiv auf die gesamte Netto N-Mineralisierung abgestimmt. Dieses Experiment zeigte, dass Mischungen von kontrastierenden Legumenosesorten unterschiedliche Muster von Netto Mineralisierung und Immobilisierung im Vergleich mit einzelnen Sorte vorweisen. Was die N-Immobilisation und -Mineralisierung betrifft, erbrachte die I. edulis Behandlung eine höhere N-Mineralisierung, während die S. paniculatum Behandlung, die bessere Wechselwirkung mit anderen hülsenartigen Sorten zeigte.

Die ${ }^{15} \mathrm{~N}$ Gewächshausexperimente, welche Reis als Indikatorpflanze verwendeten, und die ${ }^{15} \mathrm{~N}$ Laborexperimente wurden in zwei Teile gegliedert: zuerst wurden Düngemittel ${ }^{15} \mathrm{~N}$-urea $\left(3,92 \mathrm{mg} \mathrm{N}\right.$ pot $^{-1}$ mit 5,34 \% des Atoms $\left.{ }^{15} \mathrm{~N}\right)$ und hülsenartiges Blattmaterial (S. paniculatum, I. edulis und Mischung von den zwei Sorten) mit N natürlichem Überfluss kombiniert, um Mikrobenimmobilisierung- und Bodenfixierung zu erhalten. Im zweiten Teil wurde NHarnstoff Düngemittel (3,92 N mg pot ${ }^{-1}$ mit $\mathrm{N}$ am natürlichen Überfluss) und ${ }^{15} \mathrm{~N}$-labeled hülsenartiges organisches Material von der gleichen Sorte mit 0,392\% des Atoms ${ }^{15} \mathrm{~N}$ in $S$. paniculatum und $0,390 \%$ des Atoms ${ }^{15} \mathrm{~N}$ in I. edulis beziehungsweise die Menge des 
Minerals-N kombiniert, um die Menge von N-Mineralien, welches aus der Aufspaltung hervorgeht, herauszubekommen. Dabei ist die Konkurrenz zwischen Mikroorganismen, Boden + organischer Substanzfixierung und Reisabsorption von Interesse. Die Mikrobenimmobilisierung des markierten Stickstoffes blieb durch Reispflanzwachstum unberührt, aber wurde stark durch organisches Material und Stickstoffhinzufügung beeinflusst. Durch Immobilisierung des Stickstoffes und durch organisches Zersetzungsmaterial wurde hauptsächlich die Menge und Zugänglichkeit des vorhandenen Stickstoffes festgestellt. Die Unterschiede bezüglich der Stickstoffimmobilisierung durch organisches Zersetzungsmaterial der Legumenosen waren zwischen N-Behandlungen am größten, aber wurden auch durch Mischung der zwei kontrastierenden Materialbehandlungen der Hülsenfrucht beeinflusst. Im Gewächshausexperiment mit Reis als Indikatorpflanze zeigte die Behandlung durch die Mischung zweier Sorten kumulative ${ }^{15} \mathrm{~N}$-Mikrobenimmobilisierung im Boden, höhere kumulative Reistrockenmasse und Gesamt N und höhere Wiedergewinnung von ${ }^{15} \mathrm{~N}$ vom Harnstoffdüngemittel. Dieses zeigt an, dass durch die Wechselwirkung von zwei kontrastierenden hülsenartigen Sorten die Stickstoffabsorption im Reis aufgrund der Zunahme an Mineral $\mathrm{N}$ und Abnahme der Mikroben-N Immobilisierung steigt.

Die Feldstudie der „litter bags“ lief während eines Jahres innerhalb des „slash-and-mulch“ Experimentes mit kontrastierender „litter quality“ mit Acacia angustissima, A. mangium, Clitoria racemosa, Sclerolobium paniculatum, and Inga edulis und natürlicher Brachevegetation. Dieses Experiment hat ergeben, dass für die Mehrheit der Behandlungen eine anfängliche Netto N-Freigabe nicht beobachtet werden konnte. Drei Behandlungen zeigten keinerlei Freigabe des Netto N während der Experimentperiode. Die A. angustissima Behandlung, welche eine höherere anfängliche P-Konzentration und geringstes $\mathrm{C}: \mathrm{N}$ Verhältnis zeigte, hatte eine schnellere anfängliche Netto N-Freigabe mit anschließender Ansammlung im Vergleich mit einer anderen Behandlung. Die A. mangium Behandlung, die das grösste C:N Verhältnis und zum intermediären Lignin- und Phenolinhalt vorwies, zeigte eine grosse Zunahme der N-Menge in der Regenzeit. Gleiches Phänomen in der Regenzeit konnte bei der I. edulis Behandlung beobachtet werden, die die intermediäre anfängliche Pund hohe N-Konzentration, so wie hohe Lignin- und intermediäre Phenolkonzentration vorweist. Diese Ausgangsresultate verdeutlichen, dass „slash-and-mulch“ Systeme mit dicken Laubdecken in der N-Freigabe langsam sind und dass die Notwendigkeit besteht, die Synchronisierung des Nährstoffes zu verbessern, um Nachfragen der Agrarkultursysteme zu befriedigen. 
Diese Dissertation zeigt, dass die Qualität und die Quantität des organischen Materials einen wichtigen Faktor darstellen, der die Bodenstickstoffmineralisierung und -immobilisierung beeinflusst. Änderungen in den Bodenkarbonsubstraten beeinflussen die Dynamik des anorganischen Stickstoffes des Bodens wegen der Wichtigkeit des „labilen“ Karbons in der Mikrobenimmobilisierung und im Mikroben immobilisierung verbrauch des Stickstoffes. Die kontrastierenden hülsenartigen Sorten hatten unterschiedliche Muster von Netto NMineralisierung und Immobilisierung im Vergleich mit den seperaten Sorten. Die Studie präsentiert, dass die Pflanzen und Mikroben um den N im Boden in Konkurrenz treten. Weiterhin zeigen die Daten, dass eine gegenseitige N-Beschränkung und das Benutzen von gleichen N-Hilfsmitteln vorliegen. 


\section{REFERENCES}

Addiscott, T. M., Whitmore, A. P. and Powlson, D. S. (1991). Farming fertilizers and the Nitrate Problem. Wallingford, UK, CAB International.

Alef, K. (1985). Soil respiration. Methods in Applied Soil Microbiology and Biochemistry. K. Alef and P. Mannipieri (eds.). London, UK., Academic Press: 214-219.

Anderson, J. M. and Ingram, J. S. I. (1989). Tropical soil biology and fertility: a handbook of methods. Wallingford, UK, CAB International. 171p.

Anderson, J. M., Proctor, J. and Vallack, H. W. (1983). "Ecological Studies in Four Contrasting Lowland Rain Forests in Gunung Mulu National Park, Sarawak: III. Decomposition Processes and Nutrient Losses from Leaf Litter.” Journal of Ecology 71: 503-527.

Aust, S. D. and Benson, J. T. (1993). "The Fungus among Us: Use of White Rot Fungi to Biodegrade Environmental Pollutants.” Environmental Health Perspectives 101(3), Innovations.

Azhar, E. S., Verhe, R., Sandra, P. and Verstraete, W. (1986). "Binding of nitrite-N on polyphenols during nitrification." Plant and Soil 94: 369-382.

Barraclough, D. (1995). " ${ }^{15} \mathrm{~N}$ isotope dilution techniques to study soil nitrogen transformations and plant uptake." Fertilizer Research 42: 185-192.

Barraclough, D. (1997). “The direct or MIT route for nitrogen immobilization: a ${ }^{15} \mathrm{~N}$ mirror image study with Leucine and Glycine." Soil Biology and Biochemistry 29(1): 101108.

Barrett, J. E. and Burke, I. C. (2000). "Potential nitrogen immobilization in grassland soils across a soil organic matter gradient." Soil Biology and Biochemistry 32: 1707-1716.

Bauhus, J., Khanna, P. K. and Raison, R. J. (1993). "The effect of fire on carbon and nitrogen mineralization and nitrification in an Australian forest soil.” Soil Biology and Biochemistry 31: 621-639.

Bending, G. D., Turner, M. K. and Burns, I. G. (1998). "Fate of nitrogen from crop residues as affected by biochemical quality and the microbial biomass." Soil Biology and Biochemistry 30(14): 2055-2065. 
Biederbeck, V. O., Janzen, H. H., Campbell, C. A. and Zentner, R. P. (1994). “Labile soil organic matter as influenced by cropping practices in an arid environment." Soil Biology and Biochemistry 26(12): 1647-1656.

Blair, J. M., Parmelee, R. W. and Beare, M. H. (1990). “Decay Rates, Nitrogen Fluxes, and Decomposer Communiies of Single- and Mixed-Species Foliar Litter.” Ecology 71(5): 1976-1985.

Bremer, E. and Kuikman, P. (1997). "Influence of competition for nitrogen in soil on net mineralization of nitrogen." Plant and Soil 190(1): 119-126.

Bremner, J. M. (1965). Inorganic forms of nitrogen. Methods of Soil Analysis. C. A. Black. Madison, American Society of Agronomy. 2: 1179-1267.

Brienza, S. Jr. (1999). Biomass Dynamics of Fallow Vegetation Enriched with Leguminous Trees in the Eastern Amazon of Brazil. Dissertation submitted for the degree of Doctor of Agricultural Sciences of the Faculty of Agricultural Sciences. Goettingen, George-August-University: 129p.

Bristow, A. W., Ryden, J. C. and Whitehead, D. C. (1987). “The fate at several time intervals of ${ }^{15} \mathrm{~N}$-labelled ammonium nitrate applied to an established grass sward.” Journal of Soil Science 38: 245-254.

Brookes, P. C., Landman, A., Pruden, G. and Jenkinson, D. S. (1985). “Chloroform fumigation and the release of soil nitrogen: a rapid direct extraction method to measure microbial biomass nitrogen in soil.” Soil Biology and Biochemistry 17(6): 837-842.

Brown, S. and Lugo, A. E. (1992). "Biomass of Brazilian Amazonian forest: the need for good science.” Interciencia 17(4): 201-203.

Cerri, C. C., Volkoff, B. and Andreaux, F. (1991). "Nature and behaviour of organic matter in soils under natural forest, and after deforestation, burning and cultivation, near Manaus." Forest Ecology and Management 38: 247-257.

Chesson, A. (1997). Plant degradation by ruminants: parallels with litter decomposition in soils. Drive by Nature: Plant Litter Quality and Decomposition. G. Cadisch and K.E. Giller (eds.). Wallingford, UK, CAB International: 47-66. 
Choi, W.-J., Jin, S-A, Lee, S-M., Ro, H-M. and Yoo, S-H. (2001). "Corn uptake and microbial immobilization of $15 \mathrm{~N}$-labeled urea-N in soil as affected by composted pig manure." Plant and Soil 235(1): 1-9.

Compton, J. E. and Boone, R. D. (2002). "Soil nitrogen transformations and the role of light raction organic matter in forest soils." Soil Biology and Biochemistry 34(7): 933-943.

Constantinides, M. and Fownes, J. H. (1994a). "Nitrogen mineralization from leaves and litter of tropical plants: Relationship to nitrogen, lignin and soluble polyphenol concentrations." Soil Biology and Biochemistry 26(1): 49-55.

Constantinides, M. and Fownes, J. H. (1994b). "Tissue-to-solvent ratio and other factors affecting determination of soluble polyphenols in tropical leaves." Communication of Soil Science and Plant Analysis. 25(19\&20): 3221-3227.

Corre, M. D., Schnabel, R. R. and Stout, W. L. (2002). "Spatial and seasonal variation of gross nitrogen transformations and microbial biomass in a Northeastern US grassland." Soil Biology and Biochemistry 34(4): 445-457.

Davidson, E. A., Hart, S. C., Shanks, C. A. and Firestone, M. K. (1991). "Measuring gross nitrogen mineralization, immobilization, and nitrification by ${ }^{15} \mathrm{~N}$ isotopic pool dilution in intact soil cores." Journal of Soil Science 42: 335-349.

Fischer, G., and Heilig, G. K. 1998. "Population momentum and the demand on land and water resources". In: On the Edge of the Malthusian Precipice. Philosophical Transactions of the Royal Society of London B. CAB International, Wallingford, UK: 929

Flowers, R. H. and Arnold, P. W. (1993). "Immobilization and mineralization of nitrogen in soils incubated with pig slurry and ammonium sulphate." Soil Biology and Biochemistry 15: 193-198.

Forster, J. C. (1995). Soil Physical Analysis. Methods in Applied Soil Microbiology and Biochemistry. K. Alef and .P. Nannipieri (ed.). London, UK, Academic Press: 105116.

Fox, R., Myers, R. and Vallis, J. K. (1990). “The nitrogen mineralization rate of legume residues in soil as influenced by polyphenol, lignin, and nitrogen contents." $\underline{\text { Plant and }}$ Soil 129: 251-259. 
Franagan, P. W. and van Cleve, K. (1983). "Nutrient cycling in relation to decomposition and organic-matter quality in taiga ecosystems." Canadian Journal of Forest Research 13: 795-817.

Gallardo, A. and Merino, J. (1993). "Leaf Decomposition in Two Mediterranean Ecosystems of Southwest Spain: Influence of Substrate Quality.” Ecology 74(1): 152-161.

Hadas, A., Kautsky, L. and Portnoy, R. (1996). "Mineralization of composted manure and microbial dynamics in soil as affected by long-term nitrogen management." $\underline{\text { Soil }}$ Biology and Biochemistry 28(6): 733-738.

Handayanto, E., Cadisch, G. and Giller, K. E. (1997). Regulating N Mineralization from Plant Residues by Manipulation of Quality. Driven by Nature: Plant Quality and Decomposition. G. Cadisch and K.E. Giller (eds.), Wallingford, UK. CAB International: 175-185.

Haynes, R. J. (1986). The decomposition process: Mineralization, immobilization, humus formation and degradation. Mineral Nitrogen in the Plant-Soil System. R. J. Haynes (ed.). Orlando, FL., Academic Press: 52-176.

Hobbie, S. E. (2000). “Interactions between litter lignin and soil nitrogen availability during leaf litter decomposition in a Hawaiian Montane Forest.” Ecosystems 3(4): 484-494.

Hood, R. (2001). "Evaluation of a new approach to the nitrogen- ${ }^{15}$ isotope dilution technique, to estimate crop $\mathrm{N}$ uptake from organic residues in the field." Biology and Fertility of Soils 34: 156-161.

Hood, R. C., N'Goran, K., Aigner, M. and Hardarson, G. (1999). “A comparison of direct and indirect $15 \mathrm{~N}$ isotope techniques for estimating crop $\mathrm{N}$ uptake from organic residues." Plant and Soil 208(2): 259-270.

Hood, R., Merckx, R., Jensen, E. S., Powlson, D., Matijevic, M. and Hardarson, G. (2000). "Estimating crop $\mathrm{N}$ uptake from organic residues using a new approach to the ${ }^{15} \mathrm{~N}$ isotope dilution technique." Plant and Soil 223(1-2): 33-46.

Hunt, H. W., Ingham, E. R., Coleman, D. C., Elliott, E. T. and Reid, C. P. P. (1988).

"Nitrogen Limitation of Production and Decomposition in Prairie, Mountain Meadow, and Pine Forest." Ecology 69(4): 1009-1016. 
Isaac, L., Wood, C. W. and Shannon, D. (2000). "Decomposition and nitrogen release of prunings from hedgerow species assessed fro alley dropping in Haiti." Agronomy Journal 92: 501-511.

Janssen, B. H. (1996). "Nitrogen mineralization in relation to C: $\mathrm{N}$ ratio and decomposability of organic materials." Plant and Soil 191(1): 39-45.

Jansson, S. L. (1958). “Tracer studies on nitrogen transformations in soil with special attention to mineralization-immobilization relationships." Annals of the Royal Agricultural College of Sweden 24: 101-361.

Jenkinson, D. S. (1988). Determination of microbial biomass $\mathrm{C}$ and $\mathrm{N}$ in soil. Advances in Nitrogen Cycling in Agricultural Ecosystems. J. Wilson (ed.). Wallingford, UK. CAB International: $368-386$.

Jenkinson, D. S., Fox, R. H. and Rayner, J. H. (1985). "Interaction between fertilizer nitrogen and soil nitrogen: The so-called priming effect." Journal of Soil Science 36: 425-444.

Jensen, B. K., Jensen, E. S. and Magid, J. (1995). “Decomposition of ${ }^{15} \mathrm{~N}$-labelled rye grass in soils from a long-term field experiment with different manuring strategies." Nitrogen Leaching in Ecological Agriculture: 221-228.

Jensen, E. S. (1991). "Evaluation of automated analysis of ${ }^{15} \mathrm{~N}$ and total $\mathrm{N}$ in plant material and soil." Plant and Soil 133: 83-92.

Jensen, E. S. (1994). "Mineralization-immobilization of nitrogen in soil amended with low C:N ratio plant residues with different particle sizes." Soil Biology and Biochemistry 26(4): 519-521.

Jensen, E. S. (1997). "Nitrogen immobilization and mineralization during initial decomposition of ${ }^{15} \mathrm{~N}$-labelled pea and barley residues." Biology and Fertility of Soils. 24: 39-44.

Joergensen, R. G. (1995). The Fumigation Incubation Method. Methods in Applied Soil Microbiology and Biochemistry. K. Alef and P. Nannipieri (eds.). London, UK., Academic Press: 376-414.

Joergensen, R. G. and Mueller T. (1996). "The fumigation-extraction method to estimate soil microbial biomass: calibration of the $\mathrm{k}_{\mathrm{EN}}$ value." Soil Biology and Biochemistry 28(1): 33-37. 
Kalembasa, S. J. and Jenkinson, D. S. (1973). “A comparative study of titrimetric and gavimetric methods for determination of organic carbon in soil." Journal of the Science of Food and Agriculture 24: 1085-1090.

Kato, M. S. A., Kato, O. R., Denich, M. and Vlek, P. L. G. (1999). "Fire-free alternatives to slash-and-burn for shifting cultivation in the eastern Amazon region: the role of fertilizers." Field Crops Research 62(2-3): 225-237.

Kato, O. R. (1988). Fire-free Land Preparation as an Alternative to Slash-and-burn Agriculture in the Bragantina Region, Eastern Amazon: Crop Performance and Nitrogen Dynamics. Dissertation submitted for the degree of Doctor of Agricultural Sciences of the Facultay of Agricultural Sciences. Goettingen, George-AugustUniversity: 132 .

Kirkham, D. and Bartholomew, W. V. (1955). "Equations for following nutrient transformations in soil, utilizing tracer data: II.” Soil Science Society Proceedings 19: 189-192.

Kuo, S. and Sainju, U. M. (1998). "Nitrogen mineralization and availability of mixed leguminous and non-leguminous cover crop residues in soil." Biology and Fertility of Soils 26: 346-353.

Linkins, A. E., Melillo, J. M. and Sinsabaugh, R. L. (1984). Factors affecting cellulase activity in terrestrial and aquatic ecosystems. Current Perspectives in Microbial Ecology. M.J. Klug and C.A. Reddy. Washington, American Society for Microbiology: 572-579.

Lonrez, K., Preston, C. M., Raspe, S., Morrison, I. K. and Feger, K. H. (2000). “Litter decomposition an humus characteristics in Canadian and German spruce ecosystems: information from tannin analysis and ${ }^{13} \mathrm{C}$ CPMAS NMR." Soil Biology and Biochemistry 32: 779-792.

Mackensen, J., Hölscher, D., Klinge, R. and Fölster, H. (1996). "Nutrient transfer to the atmosphere by burning of debris in eastern Amazonia." Forest Ecology and Management 86: 121-128.

Mafongoya, P. L., Giller, K. E. and Palm, C.A. (1998). "Decomposition and nitrogen release patterns of tree prunings and litter.” Agroforestry Systems 38(1-3): 77-97.

Martin, J. P. and Haider, K. (1980). Microbial degradation and stabilisation of ${ }^{14} \mathrm{C}$-labelled lignins, phenols, and phenolic polymers in relation to soil humus formation. Lignin 
Biodegradation: Microbiology, Chemistry and Potential Applications. T. K. Kirk, T. Higuchi and H. M. Chang(eds.). Palm Beach, USA, CRC Press. Vol. 2: 78-100.

Mary, B., Recous, S. and Robin, D. (1998). “A model for calculating nitrogen fluxes in soil using ${ }^{15} \mathrm{~N}$ tracing." Soil Biology and Biochemistry 30(14): 1963-1979.

Meentemeyer, V. (1978). "Macroclimate the lignin control of litter decomposition rates." Ecology 59(3): 465-472.

Melillo, J. M., Aber, J. D. and Muratore, J. F. (1982). "Nitrogen and lignin control of hardwood leaf litter decomposition dynamics." Ecology 63(3): 621-626.

Moorhead, D. L., Sinsabaugh, A. E., Linkins, A. E. and Reynolds, J. F. (1996). "Decomposition processes: modelling approaches and applications." The Science of Total Environment 183: 137-149.

Myers, R. J. K., Palm C. A., Cuevas, E., Gunatilleke, I. U. N. and Brossard, M. (1994). The synchronization of nutrient mineralization and plant nutrient demand. Biological Management of Tropical Soil Fertility. P.L. Woomer and M.J. Swift (eds.). Chichester, UK, Wiley-Sayce Publication.: 81-116.

Neely, C. L., Beare, M. H., Hargrove, W. L. and Coleman, D. C. (1991). "Relationship between fungal and bacterial substrate-induced respiration (SIR), biomass and plant residue decomposition.” Soil Biology and Biochemistry 23(10): 947-954.

Nelson, D. W. and Bremner, D. W. (1969). "Factors affecting chemical transformations of nitrite in soils." Soil Biology and Biochemistry 1: 229-239.

Nepstad, D. C., Brown, I. F., Luz, L. Alechandre, A. and Viana, V. (1992). “Biotics impoverishment of Amazon forests by rubber tapers, loggers and cattle ranchers." Advances in Economical Botany 9: 1-14.

Olson, J. S. (1963). "Energy storage and the balance of producers and decomposers in ecological systems.” Ecology 44(2): 322-331.

Palm, C. A. (1995). "Contribution of agroforestry trees to nutrient requirements of intercropped plants." Agroforestry Systems 30: 105-124.

Palm, C. A. and Rowland, A. P. (1997). A Minimum Dataset for Characterization of Plant Quality for Decomposition. Drive by Nature: Plant Litter Quality and Decomposition. G. Cadisch and K. E. Giller (eds.). London, UK, CAB International: 379-392. 
Palm, C. A. and Sanchez, P. A. (1991). "Nitrogen release from the leaves of some tropical legumes as affected by their lignin and polyphenolic contents." Soil Biology and Biochemistry 23(1): 83-88.

Panda, M. M., Mosier, A. R., Mohanty, S. K., Chakravorti, S. P., Chalan, A. B. and Reddy, M. D. (1995). "Nitrogen utilization by lowland rice as affected by fertilization with urea and green manure.” Fertilizer Research 40: 215-223.

Paparcikova, L., Brienza, S. Jr., Kato, O. R. and Vlek, P. L. G. (2000). Field estimation of biological $\mathrm{N}_{2}$-fixation by five tropical tree species using ${ }^{15} \mathrm{~N}$ isotope dilution methods. German-Brazilian Workshop on Neotropical Ecosystems. Achievements and Prospects of Cooperative Research, Hamburg, Germany: 93.

Powlson, D. S. and Brookes, P.C. (1987). "Measurement of soil microbial biomass provides an early indication of changes in total soil organic matter due to straw incorporation." Soil Biology and Biochemistry 19: 159-164.

Powlson, D. S., Hirsch, P. R. and Brookes, P. C. 2001. "The role of soil microorganisms in soil organic matter conservation in the tropics." Nutrient Cycling in Agroecosystems 61(1-2): 41-51.

Priha, O. and Smolander, A. (1997). "Microbial biomass and activity in soil and litter under Pinus sylvestris, Picea abies and Betula pendula at originally similar field afforestation sites.” Biology and Fertility of Soils 24(1): 45-51.

Raison, R. J., Khanna, P. K. and Woods, P. V. (1985). "Transfer of elements to the atmosphere during low intensity prescribed fires in three Australian subalpine eucalypt forest." Canadian Journal of Forest Research 15: 657-664.

Recous, S., Fresneau, C., Faurie, G. and Mary, B. (1988). “The fate of labeled ${ }^{15} \mathrm{~N}$ urea and ammonium nitrate applied to a winter wheat crop: Nitrogen transformation in soil." Plant and Soil 112: 205-214.

Rego, R. S., Silva, B. N. R. da and Junior, R. S. O. (1993). Detailed soil survey in an area in the municipality of Igarapé-Açú. Summaries of lectures and posters presented at the $1^{\text {st }}$ SHIFT-Workshop in Belém, Brazil.

Reineking, A., Langel, R. and Schikowski, J. (1993). “15 N- ${ }^{13} \mathrm{C}$-on-line measurement with elemental analyzer (Carlo Erba, NA 1500), a modified trapping box and a gas isotope mass spectrometer (Finningan, MAT 251)." Isotopenpraxis Environmental Health Study. 29: 169-174. 
Reinerstsen, S. A., Elliot, L. F., Cochran, V. L. and Campbell, G. S. (1984). "Role of available carbon and nitrogen in determining the rate of wheat straw decomposition." Soil Biology and Biochemistry 16: 459-464.

Sanchez, P. A. 1976. Properties and Management of Soils in the Tropics. New York, USA, W-I Publication: 618.

Sanchez, P. A. and Salinas, J. G. (1982). "Low-input technology for managed Oxisols and Ultisols in tropical America." Advances in Agronomy 34: 279-406.

Schimel, J. P. (1996). “Assumption and errors in the ${ }^{15} \mathrm{NH}_{4}{ }^{+}$pool dilution thechnique for measuring mineralization and immobilization." Soil Biology and Biochemistry 28(6): $827-828$.

Schimel, J. P., Jackson, L. E. and Firestone, M. K. (1989). "Spatial and temporal effects on plant-microbial competition for inorganic nitrogen in a California annual grassland.” Soil Biology and Biochemistry 21: 1059-1066.

Seneviratne, G. (2000). "Litter quality and nitrogen release in tropical agriculture: a synthesis." Biology and Fertility of Soils. 31: 60-64.

Shen, S. M., Pruden, G. and Jenkinson, D. S. (1984). "Mineralization and immobilization of nitrogen in fumigated soil and the measurement of microbial biomass nitrogen.” Soil Biology and Biochemistry 16(5): 437-444.

Smith, M. J. (1994). Cycling of nitrogen through microbial activity. Soil Biology: Effects on Soil Quality. J.L. Hatfield and B.A. Stewart (eds.). Boca Raton, USA, CRC Press: 91120.

Sollins, P., Spycher, G. and Glassman, C. A. (1984). "Net nitrogen mineralization from lightand heavy-fraction forest soil organic matter." Soil Biology and Biochemistry 16(1): 31-37.

Sommer, R. 2000. "Water and Nutrient Balance in Deep Soils Under Shifting Cultivation With and Without Burning in the Eastern Amazon." Doctoral thesis, University of Göttingen.

Stark, J. M. and Hart, S. C. (1996). "Diffusion technique for preparing salt solutions, Kjeldahl digests, and persulfate digest for Nitrogen-15 analysis." Soil Science Society of America Journal 60: 1846-1855. 
Stark, J. M. and Schimel, J. (2001). "Errors in `Overestimation of gross N transformation rates in grassland soils." Soil Biology and Biochemistry 33(10): 1433-1435.

Stevenson, F. J. and Cole, M. A. (1999). Cycles of Soil : Carbon, Nitrogen, Phosphorus, Sulfur, Micronutrients. New York, NY, Wiley. Pp 427.

Swift, M. J., Russell-Smith, A. and Perfect, T. J. (1981). "Decomposition and MineralNutrient Dynamics of Plant Litter in a Regenerating Bush-Fallow in Sub-Humid Tropical Nigeria." Journal of Ecology 69(3): 981-995.

Thönnissen, C., Midmorea, D. J., Ladha, J. K., Olk, D. C. and Schmidhalter, U. (2000). "Legume decomposition and nitrogen release when applied as green manures to tropical vegetable production systems.” Agronomy Journal 92: 253-260.

van Soest, P. J. and Wine, R. H. (1968). "Determination of lignin and cellulose in aciddetergent fiber with permanganate." Journal of the Association of Official Analytical Chemists 51: 780-785.

Vance, E. D., Brookes, P. C. and Jenkinson, D. S. (1987). “An extraction method for measuring soil microbial biomass C.” Soil Biology and Biochemistry 19(6): 703-707.

Verchot, L. V., Holmes, Z., Mulon, L., Groffman, P. M. and Lovett, G. M. (2001). “Gross vs net rates of $\mathrm{N}$ mineralization and nitrification as indicators of functional differences between forest types." Soil Biology and Biochemistry 33(14): 1889-1901.

Vitousek, P. M., Turner, D. R., Parton, W. J. and Sanford, R. L. (1994). “Litter Decomposition on the Mauna Loa Environmental Matrix, Hawai: Patterns, Mechanisms, and Models.” Ecology 75(2): 418-429.

Wang, W. J., Chalk, P. M., Chen, D. and Smith, C. J. (2001). "Nitrogen mineralization, immobilization and loss, and their role in determining differences in net nitrogen production during waterlogged and aerobic incubation of soils." $\underline{\text { Soil Biology and }}$ Biochemistry 33(10): 1305-1315.

Watkins, N. and Barraclough, D. (1996). "Gross rates of N mineralization associated with the decomposition of plant residues." Soil Biology and Biochemistry 28(2): 169-175.

Wider, K. R. and Lang, G. E. (1982). “A Critique of the Analytical Methods Used in Examining Decomposition Data Obtained From Litter Bags.” Ecology 63(6): 16361642. 
Wilkinson, L. 1992. Systat for Windows: The system for statistics. 1990-1994. Version 5.05, Systat Inc., Evanston, Illinois, USA.

Woomer, P. L., Martin, A., Albrecht, A., Resck, D. V. S. and Scharpenseel, H. M. (1994). The importance and management of soil organic matter in the tropics. The Biological Management of Tropical Soil Fertility. P. L. Woomer and M. J. Swift (eds.). West Sussex, UK, John Wiley \& Sons: 47-80.

Yacob, O. and Blair, G. J. (1980). "Mineralization of ${ }^{15} \mathrm{~N}$-labelled legume residues in soils with different nitrogen contents and its uptake by rhodes grass." Plant and Soil 57: 237-248.

Zech, W., Haumaier, L. and Hempfling, R. (1990). Ecological aspects of soil organic matter in tropical land use. Humic Substances in Soil and Crop Sciences: Selected Reading. Madison, American Society of Agronomy and Soil Science of America: 187-202.

Zimmer, M. (2002). "Is decomposition of woodland leaf litter influenced by its species richness?" Soil Biology and Biochemistry 34(2): 277-284.

Zucker, W. V. (1982). "How aphids choose leaves: the roles of phenolics in host selection by a Galling Aphid.” Ecology 63(4): 972-981. 